BEATRIZ TREZZI VIEIRA

\title{
Radiojornalismo em emissoras católicas: a evangelização pela notícia
}


BEATRIZ TREZZI VIEIRA

\section{Radiojornalismo em emissoras católicas: a evangelização pela notícia}

Dissertação apresentada à Escola de Comunicações e Artes da Universidade de São Paulo para obtenção do título de Mestre em Ciências da Comunicação

Área de Concentração: Estudo dos Meios e da Produção Mediática

Orientador: Prof. Dr. Luciano Victor Barros Maluly

São Paulo

2013 
Autorizo a reprodução e divulgação total ou parcial deste trabalho, por qualquer meio convencional ou eletrônico, para fins de estudo e pesquisa, desde que citada a fonte.

\author{
Catalogação da Publicação \\ Serviço de Biblioteca e Documentação \\ Escola de Comunicações e Artes da Universidade de São Paulo
}

Vieira, Beatriz Trezzi.

Radiojornalismo em emissoras católicas: a evangelização pela notícia / Beatriz Trezzi Vieira; orientador Luciano Victor Barros Maluly. - São Paulo, 2013.

187 folhas.

Dissertação (Mestrado) - Universidade de São Paulo, 2013.

1. Radiojornalismo. 2. Jornalismo Católico. 3. Evangelização. I. Maluly, Luciano Victor Barros. II. Título. III. Título: Radiojornalismo em emissoras católicas: a evangelização pela notícia 
VIEIRA, B. T. Radiojornalismo em emissoras católicas: a evangelização pela notícia. Dissertação apresentada à Escola de Comunicações e Artes da Universidade de São Paulo para obtenção do título de Mestre em Ciências da Comunicação.

Aprovado em:

\section{BANCA EXAMINADORA}

Prof. Dr. Instituição:

Julgamento: Assinatura:

Prof. Dr. Instituição:

Julgamento: Assinatura:

Prof. Dr. Instituição:

Julgamento: Assinatura: 


\section{DEDICATÓRIA}

Dedico este trabalho à minha amada mãe, Julia, maior incentivadora e exemplo de vida, a meu pai, Sylvio,

e à minha avó materna, Segismunda, que sempre iluminaram e continuarão a iluminar a minha existência, estejam onde estiverem. 


\section{AGRADECIMENTOS}

Às minhas irmãs, Silvânia e Cibele, e ao meu sobrinho, Fernando, cujo afeto e apoio incondicionais são minha verdadeira razão de viver.

À Capes, pelo apoio financeiro que viabilizou a realização desta pesquisa.

Ao meu orientador, Prof. Dr. Luciano Victor Barros Maluly, pelo reconhecimento, atenção e dedicação que me permitiram realizar este projeto.

Aos amigos responsáveis por meu ingresso no Mestrado, e incentivadores desta nova fase de vida, Cesar Garcia Lima, Luiza Luzvarghi, Paulo Bontempi, Enio Moraes Jr. e Carlos

Moreno.

A Sandra de Angelis, pela sugestão do tema, colaboração constante e amizade em todas as horas.

A Isabel Sampaio, pelas considerações que permitiram aprimorar este trabalho.

A Mariana Fujisawa, pela revisão, e a Valnei Andrade, pela finalização visual desta dissertação.

Às amigas Rebeca Kritsch e Eliana Morita, eternas companheiras de batalhas.

Aos colegas orientandos contemporâneos de Mestrado, que se tornaram amigos para sempre, Nadini Lopes e Carlos Tavares Jr.

Às demais colegas orientandas, Rúbia Piancastelli, Vivian Fernandes, Maria Cristina Almeida, e aos companheiros de disciplinas, em especial, a Cristiane Reimberg e a Maria Cristina Dias Alves, pela convivência enriquecedora ao longo dos últimos dois anos e meio.

A Miriam Denardi, pelo apoio na primeira parte deste projeto, e a Anaiza Rodrigues, pela sugestão de bibliografia e inspiradora troca de ideias.

Aos professores responsáveis pelas disciplinas cursadas - Eneus Trindade Barreto Filho, Alice Mitika Koshiyama e Eugênio Bucci - e aos supervisores da atividade de monitoria (PAE) - José Luiz Proença e André Chaves de Melo Silva -, pelos preciosos ensinamentos. 
Aos funcionários do PPGCOM, da Secretaria de Pós-Graduação e do CJE, nas pessoas de Rosely Sousa, Mirian Villalba e Ricardo Gaspar, pela consideração e agilidade no atendimento aos alunos.

A Fernando Gardinalli, pela consultoria estatística.

Aos funcionários da Biblioteca da ECA, em especial a Walber Lustosa, e do Multiofício, nas pessoas de Fernando e Elaine Santos. Aos entrevistados deste projeto, pela gentileza e deferência. Às irmãs Helena Corazza e Élide Folgolari, e a Ioná Piva, da TV Aparecida, pelas informações valiosas e viabilização de entrevistas.

A todos que ajudaram a tornar este sonho realidade, minha mais sincera gratidão. 


\section{RESUMO}

Este estudo busca traçar o perfil dos radiojornais e averiguar como é produzido o jornalismo veiculado pela Rádio Aparecida AM e a Rádio Canção Nova AM, duas das mais influentes emissoras católicas do País. Uma vez que os responsáveis pelas rádios procuram evangelizar por meio da programação, nela incluída a atividade jornalística, procurou-se observar as características intrínsecas aos noticiários dessas emissoras, as quais representam segmento expressivo, em termos quantitativos, no Brasil. Por meio da análise dos radiojornais selecionados nesta pesquisa, foi possível verificar como esses estão estruturados em termos de editorias, seu conteúdo religioso, fontes entrevistadas e temas abordados, que podem ser considerados próprios do radiojornalismo católico, conforme indicam os responsáveis pelas rádios. As entrevistas a representantes da Igreja Católica e a especialistas, bem como a consulta a fontes bibliográficas, complementam as bases de reflexão sobre o jornalismo produzido em um contexto religioso. Conclui-se que a evangelização pela notícia presta um serviço à sociedade, na medida em que garante espaço a causas sociais no noticiário e procura promover os valores humanos, defender a vida e lutar por justiça, princípios inerentes também à deontologia do próprio jornalismo. Porém, é necessário que, nessa atividade, seja observado o conjunto de deveres, princípios e normas que norteiam a atividade jornalística, à luz da responsabilidade social e do interesse público, inerentes à concessão de um serviço público, como é a radiodifusão.

PALAVRAS-CHAVE: Rádio Aparecida AM, Rádio Canção Nova AM, Radiojornalismo, Jornalismo Católico, Evangelização, Igreja Católica. 


\begin{abstract}
This study aims to profile the radio news programs and examine how journalism is produced and aired by Rádio Aparecida AM and Rádio Canção Nova AM, two of the most influential Catholic broadcasters in the country. Once those responsible for the radio stations seek to evangelize through their programming, including the journalistic activity, the intrinsic characteristics to the news of these radios, which represent a significant number of stations in Brazil, were observed. Through the analysis of the news programs of these two stations, it was possible to see how they are structured in terms of editorial, religious content, sources interviewed and themes that can be considered characteristic of Catholic radio journalism, as shown by the keepers of the radios. Interviews with representatives of the Catholic Church and experts, as well as consultation to bibliographic sources, complement the basis for reflection on journalism produced in a religious context. It has been concluded that the evangelization through the news provides a service to society, as it ensures space for social causes and seeks to promote human values, defend life and fight for justice, also the principles of journalism ethics itself. However, in this activity, it must be strictly observed the set of duties, principles and standards that guide journalistic activity, in the light of social responsibility and public interest, inherent in the granting of public service broadcasting.
\end{abstract}

KEYWORDS: Rádio Aparecida AM, Rádio Canção Nova AM, Radio Journalism, Catholic Journalism, Evangelization, The Catholic Church. 


\section{SUMÁRIO}

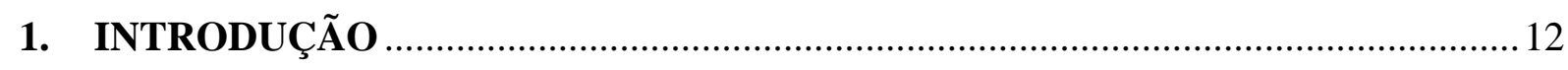

2. A Igreja Católica e os Meios de Comunicação ..................................................... 26

2.1. Meios de comunicação e Igreja: uma relação em desenvolvimento ........................ 27

2.2. O Concílio Vaticano II e os novos tempos ......................................................... 30

2.3. Documentos das Conferências Gerais do Episcopado Latino-Americano................ 33

2.4. Documentos da Conferência Nacional dos Bispos do Brasil (CNBB) .................... 34

2.5. A presença da Igreja Católica no rádio ............................................................... 36

3. Jornalismo e Evangelização em Emissoras Católicas ............................................ 41

3.1. A evangelização pelos meios de comunicação .................................................... 41

3.2. Características do jornalismo evangelizador segundo profissionais, representantes de instituições católicas e especialistas ................................................................. 47

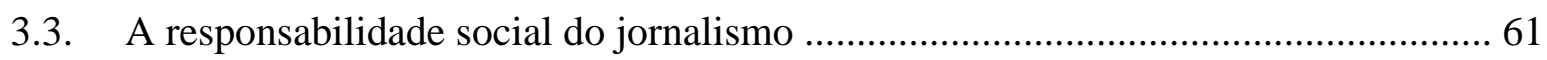

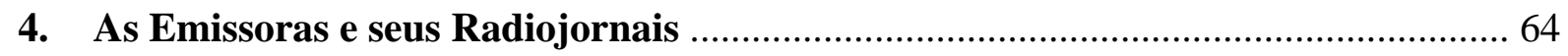

4.1. Rádio Aparecida: Tradição em jornalismo ........................................................... 68

4.2. Rádio Canção Nova: Opção pela comunicação ...................................................... 72

4.3. Metodologia de análise do perfil dos radiojornais ............................................. 77

4.4. Percentual das editorias e conteúdo religioso dos radiojornais .............................. 81

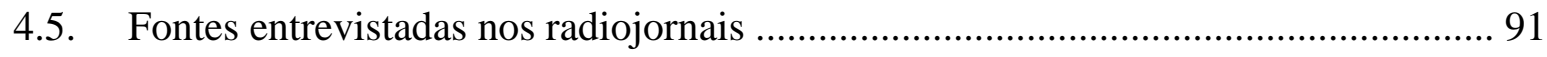

4.6. Temas de interesse católico nos radiojornais ..................................................... 99

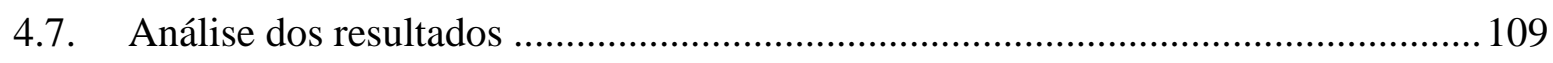

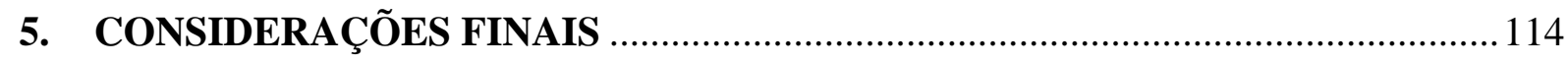

REFERÊNCIAS BIBLIOGRÁFICAS ...................................................... 114-131

APÊNDICES (A-I) - Transcrição das entrevistas ..................................................131-194

ANEXO A - Notícia: Papa Francisco reitera importância do rádio na transmissão da fé

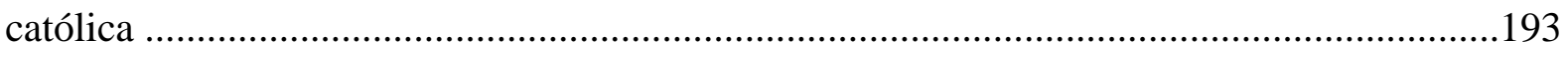

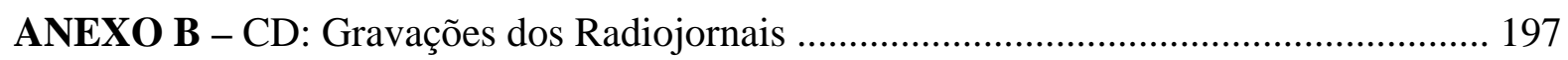




\section{LISTA DE TABELAS}

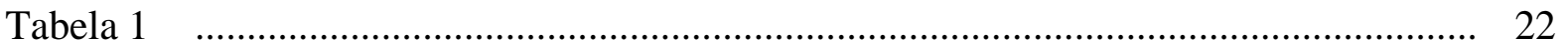

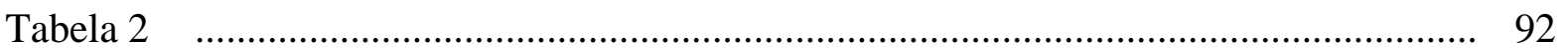

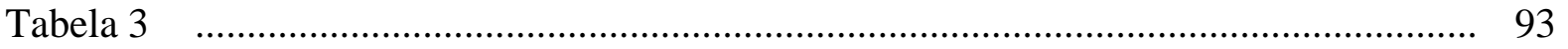

\section{LISTA DE GRÁFICOS}

Gráfico 1

Gráfico 2

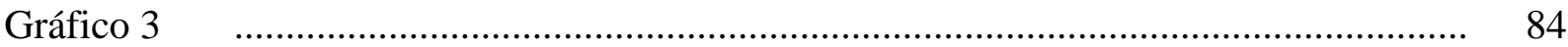

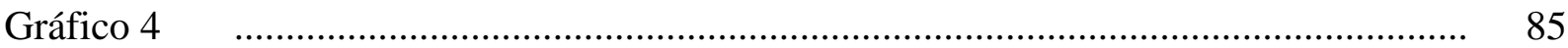

Gráfico 5

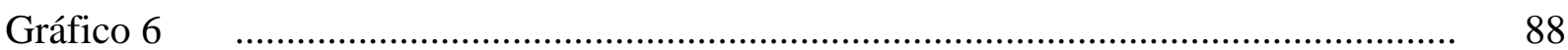

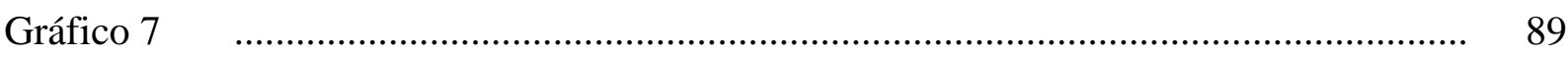

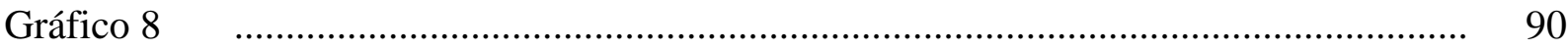

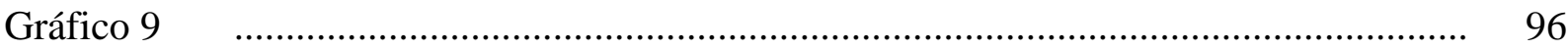

Gráfico 10

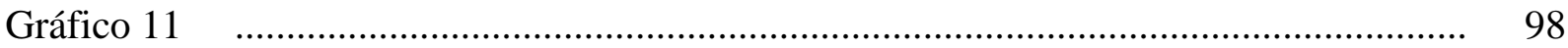

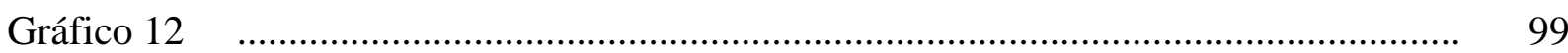

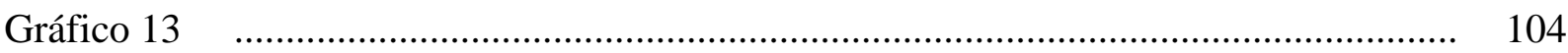

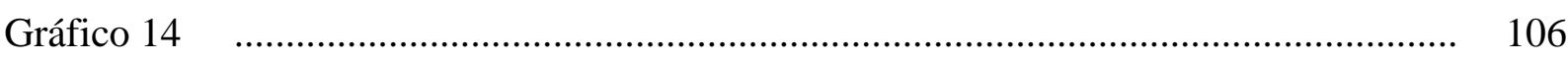

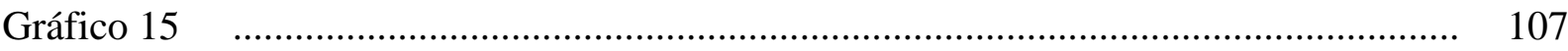

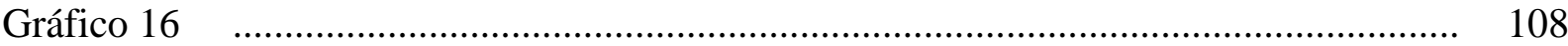




\section{INTRODUÇÃO}

Ao se constatar o predomínio dos meios de comunicação na sociedade atual, seja como formadores de opinião ou como criadores de hábitos de comportamento e consumo, bem como o papel que a atividade jornalística desempenha no contexto uma sociedade midiatizada, é possível perceber a necessidade, por parte de uma instituição como a Igreja Católica, de utilizar os meios de comunicação e valer-se da atividade jornalística para propagar sua visão de mundo, interpretando os fatos segundo seus valores e referenciais, ou, em outras palavras, sua ideologia ${ }^{1}$. E a instituição tem, tradicionalmente, marcado presença nos meios de comunicação, em especial no rádio, para realizar a sua propalada missão da evangelização ${ }^{2}$. Quem desejar conhecer a programação jornalística produzida pelas rádios católicas e pesquisar o noticiário que essas emissoras colocam no ar terá pela frente um terreno amplo e fértil que, entretanto, tem sido objeto de poucos trabalhos e pesquisas nos meios acadêmicos.

Mesmo quando produzido em um contexto institucional, como é o caso do noticiário de uma emissora católica, o jornalismo é uma atividade que busca informar e, ao mesmo tempo, formar $^{3}$, incorporando intrinsecamente o papel de agente de promoção da cidadania e da democracia, desde que ancorado na ética e na responsabilidade social e pautado pelo interesse público (MORAES JÚNIOR, 2005, 2011). A Constituição Brasileira de 1988, tida como uma das mais avançadas do mundo no âmbito da defesa das garantias individuais, assegura o direito à informação e à liberdade de expressão como alicerces do estado democrático.

\footnotetext{
${ }^{1}$ Na concepção de Louis Althusser (1985, p. 85), “a ideologia é uma ‘representação’ da relação imaginária dos indivíduos com suas condições reais de existência”. O filósofo francês de orientação marxista atribui à Igreja o papel de "aparelho ideológico de estado religioso", o qual desempenhou, particularmente durante a Idade Média, funções destacadamente escolares e culturais.

${ }^{2}$ Como veremos no Capítulo 3, o conceito de evangelização não é estanque, tendo sido discutido pela Igreja desde sua fundação, e está intrinsecamente ligado ao ato de comunicar, de partilhar, de entrar em comunhões inerentes a todo ser humano, segundo Bombonatto (2009). Para Moreira (1995, p.28), evangelizar significa “dar a boa notícia” e inclui "a luta pela justiça, a construção da fraternidade, a promoção do bem comum e a busca de mudanças sociais” (Ibidem, p. 82).

${ }^{3}$ O pesquisador norte-americano Fraser Bond identifica quatro “razões de ser fundamentais” do jornalismo: informar, interpretar, orientar e entreter (BOND, 1962, p.19). Em relação à função de orientar, o pesquisador argumenta que essa tem por objetivo “ajudar o indivíduo a compreender melhor o que lê ou o que ouve”, devidamente munido das "explicações, interpretações, material de base e diagramas" envolvendo "a notícia de um fato, um acontecimento ou de uma teoria”. (Ibidem, p. 20)
} 
Batizada de “Constituição Cidadã” pelo presidente da Câmara dos Deputados, Ulysses Guimarães, quando entrou em vigor no dia 27 de julho de 1988, a Carta Magna determina, em seu Capítulo V, intitulado “Da Comunicação Social”, que “a produção e a programação das emissoras de rádio e televisão deverão dar preferência a finalidades educativas, artísticas, culturais e informativas" ${ }^{4}$.

Dessa forma, esta pesquisa surgiu do desejo de aprofundar, sob uma perspectiva acadêmica, o entendimento sobre o fazer jornalístico em duas emissoras de rádio católicas que estão entre as de maior alcance e influência no País: a Rádio Aparecida AM, de Aparecida, e a Rádio Canção Nova AM, de Cachoeira Paulista ${ }^{5}$, ambas com sede nas citadas cidades do interior do Estado de São Paulo, averiguando seus padrões e limites. Em complemento à programação religiosa, cuja proposta é essencialmente evangelizar por meio do rádio, essas emissoras optaram, pouco após o início de suas atividades (a primeira foi fundada em 1951 e a segunda, em 1980), por incorporar o jornalismo e a prestação de serviço como formas de informar aos ouvintes sobre os temas que envolvem e afetam a sua realidade cotidiana.

Parte-se dos princípios de que a informação, em particular a jornalística, é uma necessidade dos cidadãos para viverem em sociedade, para a consolidação da cidadania e para a viabilização plena da democracia; de que o jornalista exerce uma função de responsabilidade social (MEDINA, 1982); e de que a veiculação da notícia pelo rádio é uma forma de garantir o caráter público e social desse meio que permanece como um dos de maior abrangência e popularidade no País.

De acordo com último Censo Demográfico do Instituto Brasileiro de Geografia e Estatística (IBGE), realizado em 2010, 97\% dos lares brasileiros contavam naquele ano com televisores, frente aos $85 \%$ do ano de 2000. No mesmo período, a presença de aparelhos convencionais de rádio caiu de 87,45\% para 81,4\% do total. Mesmo tendo sido verificada uma queda do número de aparelhos, entretanto, esse processo não representa uma redução da influência do rádio no País, segundo o diretor-geral da Associação Brasileira de Emissoras de

\footnotetext{
${ }^{4}$ Constituição da República Federativa do Brasil de 1988, Capítulo V, Artigo 221, Inciso I. Disponível em http://www.planalto.gov.br/ccivil_03/Constituicao/Constituicao.htm. Acesso em 30 de abril de 2012.

${ }^{5}$ A programação das rádios pode ser acessada, respectivamente, pelos sites http://www.a12.com/radioam e http://radio.cancaonova.com.
} 
Rádio e Televisão (Abert), Luis Roberto Antonik, em nota da entidade datada de 17 de novembro de 2011, após divulgação dos dados do recenseamento pelo IBGE ${ }^{6}$.

"A pergunta do instituto não é se o brasileiro ouve rádio, mas se ele tem um aparelho de rádio no domicilio", afirma o diretor da Abert. "Com a modernização e a convergência tecnológica, os receptores tradicionais de rádio cedem espaço a novos aparelhos, como celulares, computadores, smartphones e tocadores de MP3, como os Ipods”, observa Antonik. Ao final de 2010, 36\% dos 202,9 milhões de aparelhos celulares em poder dos brasileiros estavam equipados com aparelhos de rádio - uma soma aproximada de 75 milhões de receptores. "O número deve ser maior em 2011, porque, desde 2002, a quantidade de domicílios com celular cresce mais de $15 \%$ ao ano. Esses dados não constam das estatísticas do IBGE”, acrescenta.

A área econômica da Abert considera que os diversos receptores de rádio no Brasil deram um salto nos últimos anos, chegando à casa dos 300 milhões. Um grande número de receptores de rádio também está nos veículos. "Se considerarmos que 80\% dos 29,9 milhões de carros possuem aparelho de rádio, são mais de 23,92 milhões de receptores agregados à vida dos brasileiros”, complementa o diretor da Abert.

O professor e pesquisador do Programa de Mestrado em Comunicação da Faculdade Cásper Líbero José Eugenio de Oliveira Menezes lembra no estudo Rádio e Cidade Vínculos Sonoros que os diversos meios de comunicação atuam de forma complementar na sincronização das atividades dos habitantes das grandes cidades. "No universo dos meios, o rádio tem o seu lugar especial, não é um veículo do passado, mas uma das mais importantes expressões da cultura do ouvir” (MENEZES, 2007, p.83) ${ }^{7}$.

Dessa forma, analisam-se os fatores intrínsecos ao jornalismo praticado nas rádios católicas, que representam um dos segmentos mais expressivos em número de emissoras no

\footnotetext{
${ }^{6}$ Disponível em http://www.abert.org.br/site/index.php?/noticias/todas-noticias/ibge-divulga-dados-estatisticosde-radio-e-tv.html\#sthash.uLJuRB8C.dpuf. Acesso em 15 de maio de 2012.

${ }^{7}$ Sobre a cultura do ouvir, diz o autor, em outro estudo: “A compreensão do universo da cultura do ouvir nos remete tanto aos tempos das grandes narrativas mitológicas quanto à atual valorização das histórias que, antes de dormir, algumas famílias contam às crianças. Nesse contexto, ainda consideramos pouco estudada a passagem da ênfase no ouvir para o processo civilizatório que gerou o predomínio da cultura do ver - ou cultura da imagem (MENEZES, 2012, p. 22).
} 
Brasil. Atualmente, estima-se ${ }^{8}$ que mais de 200 emissoras estejam nas mãos de grupos católicos no território nacional, representando em torno de $6 \%$ do total de emissoras do País, nas diversas faixas de ondas - Ondas Médias (OM), Frequência Modulada (FM), Ondas Tropicais (OT) e Ondas Curtas (OC) -, entre comerciais e educativas, constituindo-se, portanto, num espaço privilegiado e tradicionalmente um dos mais populares entre nós ${ }^{9}$.

As estatísticas mostram que, apesar do avanço de outras denominações religiosas verificado nos últimos anos, em particular de grupos pentecostais e neopentecostais, o Brasil continua sendo o país com o maior número de católicos no mundo. Ainda de acordo com os resultados do último Censo do $\mathrm{IBGE}^{10}$, a maioria da população brasileira, 68,4\%, ainda é de católicos, correspondendo a um contingente de 130 milhões de pessoas, embora a queda no total de seguidores seja maior a cada ano. Segundo o estudo, o catolicismo, que já vinha caindo em comparação com primeiros registros censitários brasileiros - que datam de 1872, quando os católicos no Brasil representavam 99,72\% da população -, passou a retroceder a taxas mais aceleradas a partir da década de 1990.

Em 2003, 74\% dos brasileiros se declaravam católicos. Em 2010, o número caiu para os $68,4 \%$ observados, sendo a maior redução verificada entre jovens e mulheres. O número de evangélicos, incluindo as igrejas tradicionais, por seu turno, subiu de 17,9\% para 20,2\%, aumentando também o número de pessoas que afirmam não ter religião: de 5,1\% para 6,7\%. O documento mostra, ainda, que o catolicismo é a religião predominante tanto entre a população de mais baixa renda $(72,8 \%$ na classe E) quanto na parcela que representa a elite econômica (69,1\% nas classes A e B), agregando 68,7\% da renda nacional.

Dessa forma, como objetivo geral, a pesquisa procura determinar, por meio de referências teóricas, de entrevistas realizadas com profissionais das rádios, especialistas e representantes

8 Dados informados pelo frei João Carlos Romanini, presidente da Rede Católica de Rádio (RCR) - entidade que reúne as emissoras católicas em todo o País -, em entrevista concedida à autora no dia 22 de fevereiro de 2013. Tal número faz das rádios católicas a maior rede de rádios do Brasil

9 Total de emissoras de rádios: comerciais: 3.222; educativas: 164; e comunitárias: 4.377. Informações disponíveis no portal do Ministério das Comunicações nos itens Rádio e TV/Radiodifusão/ Dados de Outorga. Disponível em http://www.mc.gov.br/radiodifusao/dados-de-outorga/23457-dados-gerais. Acesso em 19 de janeiro de 2012.

10 Disponível em ftp://ftp.ibge.gov.br/Censos/Censo_Demografico_2010/Caracteristicas_Gerais_Religiao_Deficiencia/caracteristi cas_religiao_deficiencia.pdf. Acesso em 30 de junho de 2012. 
da Igreja Católica, bem como da análise dos radiojornais das duas emissoras estudadas, se existe um diferencial, ou seja, um modo de fazer jornalístico característico das rádios católicas. Partiu-se da hipótese, afinal constatada, de que as emissoras procuram evangelizar por meio da programação como um todo, incluindo o noticiário veiculado.

Como objetivo específico está o de elucidar as seguintes questões: como os responsáveis pelos radiojornais encaram a atividade jornalística e qual sua motivação para a prática do jornalismo ${ }^{11}$; partindo do princípio de que buscam evangelizar por meio do jornalismo, de que forma o fazem; quais as linhas editoriais, pauta e orientações adotadas pelas rádios; como é feita a seleção de notícias; qual o conteúdo e características desses jornais; e se, ao produzir o noticiário jornalístico, as emissoras tornam-se agentes promotores da educação, de fortalecimento da democracia e da cidadania, como é de se esperar dos detentores de concessões públicas, no caso as emissoras de rádio ${ }^{12}$. Verificou-se que o jornalismo praticado em emissoras católicas desempenha uma função educadora e formadora, em convergência com a função evangelizadora da programação, ou seja, busca informar os ouvintes, ao mesmo tempo em que procura “formá-los” à luz dos valores humanitários, éticos e das posturas cidadãs, conforme definido pelos profissionais das rádios, pelos representantes de entidades católicas e pelos especialistas entrevistados ${ }^{13}$.

Entre as perguntas específicas estabelecidas para a análise do trabalho das emissoras estão: os programas jornalísticos das rádios católicas têm uma linha editorial diferenciada em relação ao noticiário jornalístico em geral? Qual o perfil desse noticiário em termos de editorias e temas abordados? Qual a parcela do noticiário dedicada à cobertura sobre a Igreja

\footnotetext{
${ }^{11}$ O Código Brasileiro de Telecomunicações, instituído pela Lei no 4.117, de 27 de agosto de 1962, determina, em seu Capítulo V, artigo 38, letra h: "As emissoras de radiodifusão, inclusive televisão, deverão cumprir sua finalidade, destinando um mínimo de 5\% (cinco por cento) de seu tempo à transmissão de serviço noticioso”.

12 Também no Capítulo V, letra d, o código ressalta "as finalidades educativas e culturais inerentes à radiodifusão, visando aos superiores interesses do país”.

${ }^{13}$ Primeiramente, foram realizadas entrevistas com profissionais das rádios entre julho e agosto de 2011. Na Rádio Aparecida, o padre César Moreira, diretor-geral, Antonio Celso Pinelli, gerente comercial, e Ederson Santos, editor de Jornalismo. Na Rádio Canção Nova, Catarina Jatobá e Reinaldo César, respectivamente editora e apresentador do Jornal Canção Nova $2^{a}$ Edição. Posteriormente, entre novembro de 2012 e março de 2013, passou-se às entrevistas com especialistas e representantes de instituições católicas: a irmã paulina Vera Ivanise Bombonato, doutora em Teologia, o presidente da Rede Católica de Rádio (RCR), frei João Carlos Romanini, e com o presidente da Comissão Episcopal Pastoral para a Comunicação da Conferência Nacional dos Bispos do Brasil (CNBB), dom Dimas Lara Barbosa, bem como com um especialista no tema da imprensa católica, o professor José Marques de Melo, diretor titular da Cátedra Unesco/Metodista de Comunicação e professor emérito do Departamento de Jornalismo da Escola de Comunicações e Artes da Universidade de São Paulo.
} 
Católica? E quais as fontes ouvidas pelas rádios? A pesquisa tem como proposta básica contribuir para o estudo e o debate em torno do jornalismo praticado em emissoras religiosas, bem como servir como um referencial para os profissionais que nelas atuam.

Desse modo, a justificativa deste estudo reside na relevância da análise a que se propõe: uma visão aprofundada sobre a produção do radiojornalismo em emissoras católicas, que representam parcela significativa em seu segmento específico, o religioso. Além disso, ao atingirem um enorme contingente de ouvintes cativos e esporádicos, assim como interessados em geral, em todas as regiões do País ${ }^{14}$, as rádios católicas assumem automaticamente uma missão social e educativa, ao lado da informativa, quando se dedicam ao jornalismo, atividade cuja natureza está estreitamente relacionada à responsabilidade social e ao interesse público.

A reflexão a ser desenvolvida ao longo deste projeto será tão mais valiosa quanto puder oferecer uma perspectiva atual do radiojornalismo produzido pelas emissoras em estudo e seu potencial de influência junto ao público, auxiliando as próprias rádios e os profissionais envolvidos nesse trabalho a aperfeiçoar as práticas e posturas efetivamente cidadãs, pensando no papel formador e orientador que podem e devem desempenhar.

Como arcabouço teórico para essa compreensão, no Capítulo 2 apresenta-se um panorama histórico sobre a visão e as diretrizes Igreja Católica em relação aos meios de comunicação - em particular o rádio -, e sobre como a instituição vem utilizando esses meios em seu propósito de evangelizar. O capítulo mostra, ainda, a trajetória sobre como a Igreja Católica vem utilizando o rádio para a evangelização no Brasil ${ }^{15}$.

No Capítulo 3, traça-se um paralelo e possíveis conexões entre os conceitos e funções das atividades evangelizadora e jornalística, bem como o papel social que o jornalismo desempenha em sua essência - sua contribuição para a disseminação de valores humanitários, promoção da cidadania, educação e consolidação da democracia em nossa sociedade, na visão de diversos autores que se dedicaram ao estudo do tema.

\footnotetext{
${ }^{14}$ Ver nota 8, na página 15.

${ }^{15}$ Um olhar mais atento sobre essa realidade, como o abordado mais adiante, no Capítulo 3, revela que o debate em torno do conceito e das formas de evangelização sempre mobilizaram a instituição sem que, entretanto, se chegasse a um conceito único e consensual.
} 
A partir de levantamento sobre as origens, diretrizes e formas de evangelização adotadas pela Igreja Católica, assim como sobre o uso que a instituição tem feito dos meios de comunicação - nele inserida a atividade jornalística -, são propostos um questionamento e uma reflexão sobre as finalidades, relações e laços possíveis entre a atividade evangelizadora e o jornalismo em sua função social. Outra proposta desse capítulo será também a de buscar compreender como os profissionais das emissoras em estudo, os representantes de instituições católicas, assim como os especialistas, conceituam e definem o jornalismo produzido nas rádios católicas.

Em seguida, no Capítulo 4, será apresentado um histórico das rádios analisadas e de suas programações, com destaque para a evolução da produção jornalística inserida nessas grades. Também serão apresentados os resultados da análise do radiojornais, que utiliza metodologia baseada em proposta apresentada por Luciano Victor Barros Maluly (2008) ${ }^{16}$, professor e pesquisador da Escola de Comunicações e Artes da Universidade de São Paulo.

Para tanto, foi observada, primeiramente nesta análise, a estruturação dos radiojornais em termos de editorias. Em paralelo, verificou-se a parcela de notícias sobre a Igreja Católica (agrupadas como editoria de Religião), somando-se a essas as notícias que utilizam fontes ligadas à instituição, as que fazem alguma divulgação promocional da instituição - no caso específico do Jornal Canção Nova $2^{a}$ Edição, da Rádio Canção Nova -, ou que veiculem a opinião da emissora - como nos editoriais do Jornal Brasil Hoje, da Rádio Aparecida. Tal levantamento permitiu conhecer o peso ou determinar a prevalência da presença da Igreja Católica em cada um dos radiojornais em estudo.

Foi analisado, ainda, o perfil das fontes entrevistadas em termos de categorias, segundo a classificação de Nilson Lage (2001, pp. 63-67) ${ }^{17}$, professor e pesquisador da Universidade Federal de Santa Catarina (UFSC), com os respectivos tempos de sonoras. Outra linha de

\footnotetext{
${ }^{16}$ A metodologia citada utiliza a análise de quantidade e de tempo para traçar o perfil de radiojornais, em termos de editorias (Cidades, Economia, Esporte Internacional, Política, Meio Ambiente, Ciência e Tecnologia), gêneros utilizados (nota, boletim, entrevista, reportagem artigo, coluna, comentário, crônica, editorial, resenha, seção do ouvinte, entre outros), fontes (protagonistas, especialistas ou testemunhas), vozes (locutores, repórteres, colaboradores, ouvintes e entrevistados), emissões (internas ou externas), transmissão (gravada, ao vivo ou mista) e conteúdo (denúncia, serviço, inovação e violência).

${ }^{17}$ De forma geral, fontes oficiais, independentes, especialistas e protagonistas (ver Capítulo 4, p. 82).
} 
observação focou os temas do noticiário apontados como sendo de especial interesse para uma emissora católica, segundo profissionais e representantes da instituição.

A pesquisa procurou verificar, também, em especial por meio das entrevistas com profissionais das rádios estudadas, com os representantes da Igreja Católica e com especialistas, os padrões, dificuldades e limites do fazer jornalístico nesse contexto específico. Em particular, abordou-se com os entrevistados até que ponto, no caso de uma rádio dessa natureza, é possível informar o ouvinte com objetividade, ao serem abordados temas considerados polêmicos ou que tenham uma posição já ideologicamente definida pela Igreja, como ocorre com notícias de denúncias ou escândalos envolvendo a instituição.

Dessa forma, a pesquisa realizada busca contribuir para o debate em torno dos noticiários produzidos por instituições religiosas, no sentido de definir de que forma esses contribuem para informar os cidadãos: se de maneira independente ou parcialmente independente. Levase em consideração que, na sociedade atual, a busca por novos espaços dentro da esfera pública passa necessariamente pelo poder de interferência na agenda midiática e que, como consequência desse processo, sujeitos sociais passaram a capacitar-se para produzir conteúdo jornalístico, dando origem ao fenômeno chamado de “Revolução das Fontes” (SANT’ANNA, 2007), originado pelas possibilidades oferecidas pelas novas tecnologias de difusão, graças às quais a notícia se tornou uma eficiente ferramenta de promoção institucional no meio social.

Este estudo procurou, ainda, observar a natureza do noticiário produzido por essas duas emissoras, que contam com uma sólida tradição de prática jornalística, nesse caso inserida no contexto de uma instituição religiosa. A verificação sobre como estão estruturados e como se apresentam os radiojornais nessas emissoras religiosas torna-se tarefa importante para compreender se o jornalismo produzido em tal realidade é, de fato, um meio para que o público possa obter informações com transparência ou se, na verdade, tratam-se de radiojornais em que o espírito de promoção da instituição evidencia-se como fator primário.

A bibliografia referencial selecionada inclui documentos da própria Igreja Católica abordando temas como a importância dos meios de comunicação na missão evangelizadora, as concepções e diretrizes da instituição para a prática da evangelização pela comunicação, bem como o pensamento de autores especializados nessas temáticas. Ao lado desses 
conceitos, discutem-se os papéis e funções que o jornalismo deve desempenhar em nossa sociedade, segundo diversos especialistas que se debruçaram sobre o tema.

Na abordagem sobre a relação da Igreja Católica com os meios de comunicação e sobre a utilização desses meios para evangelização, toma-se como referência especialistas como Ismar de Oliveira Soares (1988), Joana Puntel (1994, 2007, 2010 e 2011), Antônio César Moreira Miguel (1995) ${ }^{18}$, Helena Corazza (2000, 2004, 2007), José Marques de Melo (2005 e 2008), Vera Ivanise Bombonatto (2009, 2011), Élide Maria Folgolari e Rosane da Silva Borges (2009), Pedro Gilberto Gomes (2010) e Paulo Roque Gasparetto (2011), dentre outros. Nessa linha de estudo, foram ainda consultados diversos documentos originais divulgados pelo Vaticano, por sua instância de representação na América Latina, o Conselho Episcopal Latino-Americano (Celam) e, no Brasil, pela Conferência Episcopal dos Bispos do Brasil (CNBB), versando sobre os temas da evangelização pelos meios de comunicação e do papel que esses meios podem desempenhar na sociedade, segundo a ótica da Igreja Católica.

Segue-se uma linha de referência que oferece sustentação para uma reflexão sobre as funções e o papel da atividade jornalística na construção de uma sociedade cidadã e democrática, com autores como como Luiz Beltrão (1960, 2006), Fraser Bond (1962), Robert Park (1966), Cremilda Medina (1982), Victor Gentilli (1995), Nilson Lage (2001, 2005), Cicilia Peruzzo (2002), Alzira Alves Abreu (2003), Bill Kovach e Tom Rosenstiel (2004), Nelson Traquina (2004) e Enio Moraes Jr. (2005, 2011).

Conforme exposto anteriormente, uma das bases para a análise desenvolvida na dissertação apoiou-se em entrevistas como forma de compreensão do jornalismo exercido em emissoras católicas. Para tanto, foram ouvidos profissionais das rádios analisadas, abordando a trajetória do jornalismo nessas emissoras, a produção dos radiojornais, a elaboração das pautas, as linhas editoriais adotadas e os critérios de edição utilizados.

Da Rádio Aparecida, foram entrevistados, em julho e agosto de 2011, o padre César Moreira, diretor-geral, Ederson Santos, editor de Jornalismo, e Antonio Celso Pinelli, diretor comercial da emissora. Na Canção Nova, os entrevistados foram Catarina Jatobá, editora do Jornal Canção Nova $2^{a}$ Edição e o apresentador Reinaldo César. No mesmo período, julho/agosto de 2011, foram feitas gravações preliminares dos radiojornais transmitidos pelas

${ }^{18} \mathrm{O}$ autor assina como César Moreira. 
emissoras durante uma semana (segunda a sexta) para avaliação do material que seria analisado futuramente na dissertação. Esse levantamento foi fundamental para o conhecimento mais aprofundado do trabalho dos jornalistas e especialistas que participam da construção das pautas, linha editorial e dos comentários nos programas.

No dia 2 novembro de 2012, foi realizada uma entrevista com a irmã paulina Vera Ivanise Bombonatto, doutora em Teologia e especialista no tema da evangelização na cultura da comunicação. O diálogo com a especialista contribuiu para uma melhor compreensão sobre a temática apresentada Capítulo 3 da dissertação, que aborda o pensamento da Igreja Católica sobre a evangelização e a maneira como essa atividade vem se transformando ao longo do tempo.

Para ampliar ainda mais a discussão, inserindo o jornalismo e o radiojornalismo no contexto da evangelização, foi entrevistado, no dia 9 de fevereiro de 2013, o presidente da Comissão Episcopal Pastoral para a Comunicação da Conferência Nacional dos Bispos do Brasil (CNBB), dom Dimas Lara Barbosa, atual arcebispo de Campo Grande e ex-secretáriogeral da CNBB (2007-2011). Essa entrevista, em particular, permitiu tomar ciência do pensamento da instância de representação da Igreja Católica no Brasil sobre esses temas.

No dia 22 de fevereiro de 2013, foi realizada entrevista com o frei João Carlos Romanini, presidente da Rede Católica de Rádio (RCR), associação que reúne as emissoras de rádio católicas de todo o Brasil. O entrevistado foi indagado sobre a importância dos meios de comunicação, em particular o rádio, para a Igreja Católica, e sobre a forma com que a instituição vem utilizando esses meios no intuito de realizar sua missão de evangelizar.

Para melhor compreensão da trajetória e conceituação do jornalismo católico e dos limites e contornos do jornalismo institucional, mais especificamente para a compreensão do jornalismo praticado por uma instituição como a Igreja Católica, foi entrevistado, também no primeiro semestre de 2013, no dia 12 de março, um dos maiores especialistas brasileiros no tema da comunicação eclesial no Brasil: o professor José Marques de Melo. Ao todo, foram nove entrevistados, conforme mostra a Tabela 1. 


\begin{tabular}{|c|c|c|}
\hline Entrevistado & Função & Data e Local \\
\hline Padre César Moreira & $\begin{array}{c}\text { Diretor da Rádio e TV } \\
\text { Aparecida }\end{array}$ & 09/07/2011, São Paulo \\
\hline Ederson Santos & $\begin{array}{c}\text { Editor de jornalismo da } \\
\text { Rádio Aparecida }\end{array}$ & $04 / 08 / 2011$, Aparecida \\
\hline Antonio Celso Pinelli & $\begin{array}{c}\text { Gerente comercial da } \\
\text { Rádio Aparecida }\end{array}$ & $04 / 08 / 2011$, Aparecida \\
\hline Catarina Jatobá & $\begin{array}{c}\text { Editora do Jornal } \\
\text { Canção Nova } 2^{a} \text { Edição }\end{array}$ & $\begin{array}{c}10 / 08 / 11 \text {, Cachoeira } \\
\text { Paulista }\end{array}$ \\
\hline Reinaldo César & $\begin{array}{c}\text { Apresentador do Jornal } \\
\text { Canção Nova } 2^{a} \text { Edição }\end{array}$ & $\begin{array}{c}10 / 08 / 11 \text {, Cachoeira } \\
\text { Paulista }\end{array}$ \\
\hline Vera Ivanise & $\begin{array}{c}\text { Especialista em } \\
\text { Teologia }\end{array}$ & $02 / 11 / 2012$, São Paulo \\
\hline Bombonato & $\begin{array}{c}\text { Presidente da Comissão } \\
\text { Episcopal Pastoral para } \\
\text { a Comunicação da } \\
\text { CNBB }\end{array}$ & $09 / 02 / 2013$, São Paulo \\
\hline Barbosa & $\begin{array}{c}\text { Presidente da Rede } \\
\text { Católica de Rádio } \\
\text { (RCR) }\end{array}$ & $22 / 02 / 2013$, São Paulo \\
\hline Frei João Carlos & Especialista no tema \\
Romanini & comunicação eclesial & $12 / 03 / 2013$, São Paulo \\
\hline José Marques de Melo
\end{tabular}

Tabela 1 - Entrevistas com profissionais das rádios, especialistas e representantes de instituições católicas.

Para todas as entrevistas, foram formulados roteiros semi-estruturados de perguntas (DUARTE, 2005, p.66). No caso dos profissionais, buscou-se compreender o processo de seleção e edição de notícias nas rádios, assim como o conceito que têm sobre o jornalismo “evangelizador”, que dizem praticar. Já os especialistas, como o representante da Rede Católica de Rádio e da CNBB, foram indagados sobre a inter-relação entre evangelização e comunicação, com o jornalismo inserido nesse contexto. Dessa forma, foi possível introduzir um debate relacionado à evangelização pela comunicação, em particular pelo meio rádio, assim como procurar compreender o processo de produção e apresentação do jornalismo em uma emissora católica (ver principalmente o Capítulo 3, pp. 48-60).

Antes da realização da análise dos programas, foi selecionada uma amostra de cinco edições de dois radiojornais, sendo um de cada emissora - o Jornal Brasil Hoje, transmitido de segunda a sábado (foram consideradas as edições de segunda a sexta), das 7 horas às 7h30 pela Rádio Aparecida AM, e o Jornal Canção Nova $2^{a}$ Edição, transmitido de segunda a 
sexta-feira, das 13 horas às 13 h30 pela Rádio Canção Nova $\mathrm{AM}^{19}$. A seleção esteve focada no período de 30 de julho a 31 de agosto de 2012, tendo sido escolhida uma edição de cada dia da semana em semanas subsequentes. Dessa forma, foram gravados 10 radiojornais, sendo um de cada dia da semana (segunda a sexta), ao longo de cinco semanas. Essa opção teve por objetivo evitar que se repetisse a prevalência de um tema (suíte, no jargão jornalístico) que tenha tido destaque em determinados dias seguidos.

O período foi escolhido também em virtude de ser uma época em que é menor a ocorrência de grandes eventos religiosos, o que possibilitou acompanhar edições que abordavam os principais temas em destaque no cotidiano, em termos de Economia, Política, Internacional, Geral e Esportes, sem que uma parcela do noticiário fosse prioritariamente dedicada às notícias sobre Religião.

Considerando o universo das rádios católicas brasileiras, foram selecionadas como objeto as duas emissoras citadas pelo fato de diferenciarem-se das demais em seu segmento, em virtude do destaque que dão ao jornalismo na programação e pelo profissionalismo que procuram conferir ao exercício dessa atividade. Com 62 anos de história, a Rádio Aparecida (AM 820) sempre teve o noticiário - em que a opinião representada pelos editoriais são um diferencial - como um dos carros-chefe de sua programação (o Departamento de Jornalismo foi criado sete anos após a sua fundação, em 1958, mas a rádio já veiculava notícias esportivas desde de 1956). A proposta da emissora, segundo os profissionais que nela atuam, é a da prestação de serviço, aliada à denúncia e discussão dos problemas do País e da região (Vale do Paraíba), com enfoque na defesa dos direitos dos cidadãos ${ }^{20}$.

A Rádio Canção Nova (AM 1020) transmite o noticiário por meio de boletins diários desde sua inauguração, em 1980, e, a partir de 1994, pelo Jornal Canção Nova, $1^{a}$ e $2^{a}$ Edições (de segunda a sexta, respectivamente, das 6 horas às 6 h30 e das 12 horas às 12h30). Já por ocasião de sua fundação, em 1978, a Comunidade Canção Nova, detentora da rádio,

\footnotetext{
${ }^{19}$ No primeiro semestre de 2012, o jornal passou a ser transmitido das 12 horas às 12h30, também de segunda a sexta-feira.

${ }^{20}$ Ver entrevistas com os representantes da Rádio Aparecida: o diretor-geral, padre César Moreira (APÊNDICE A), o editor de Jornalismo, Ederson Santos (APÊNDICE B), e o gerente comercial, Antonio Celso Pinelli (APÊNDICE C). Ver também o histórico da Rádio Aparecida, no Capítulo 4.
} 
demonstrava interesse pela "evangelização pelos meios de comunicação"21 e pela formação de equipes profissionalmente preparadas. Tal postura levou a instituição a lançar o curso de Jornalismo da Faculdade Canção Nova, no segundo semestre de $2011^{22}$.

As duas emissoras, embora classificadas como comerciais, são mantidas em grande parte (integralmente, no caso da Canção Nova) por doações de ouvintes. As rádios foram pioneiras dos sofisticados complexos de comunicação que atualmente englobam as redes TV Aparecida e Canção Nova, cujas grades de programação também veiculam noticiário, tomando por base o jornalismo praticado nas rádios ${ }^{23}$.

Elas também representam diferentes linhas de atuação dentro da Igreja Católica. A Rádio Aparecida, fundada pelos padres da Congregação do Santíssimo Redentor, posiciona-se como defensora de um modelo relacionado à promoção da cidadania, optando tradicionalmente por posições sociais críticas e combativas, expressas por meio da opinião, enquanto a Rádio Canção Nova, pertencente à Fundação João Paulo II e ligada ao movimento da Renovação Carismática Católica, segue por uma linha mais espiritualista no cenário da Igreja ${ }^{24}$. Tendo como slogan: "Uma emissora a serviço da vida e da esperança” e "Nós espalhamos o amor pelo ar”, a emissora adota uma linha editorial mais positiva em seu noticiário, segundo relatam os profissionais que nela atuam.

Conforme explicitado anteriormente, da Rádio Aparecida foi selecionado o Jornal Brasil Hoje, transmitido de segunda a sábado, das 7 horas às 7h30 (para a análise, foi selecionada amostra de segunda a sexta), simultaneamente pelas emissoras ligadas à Rede Católica de Rádio (RCR), e que apresenta os principais destaques do noticiário nacional, além de informar sobre os fatos relevantes da Igreja Católica no Brasil e no mundo ${ }^{25}$. Uma rede de

\footnotetext{
${ }^{21}$ Disponível em http://comunidade.cancaonova.com/meios-de-comunicacao. Acesso em 15 de julho de 2012. Ver também o histórico da Rádio Canção Nova, no Capítulo 4.

${ }^{22}$ Disponível em http://www.fcn.edu.br/ensino/apresentacao. Acesso em 4 de janeiro de 2012.

${ }^{23}$ Conforme relato dos responsáveis pelos radiojornais das emissoras, obtido em entrevistas realizadas nos dias 4 e 10 de agosto de 2011, respectivamente.

${ }^{24}$ Segundo Libânio (2012), são cinco os cenários atuais da Igreja: a instituição, a carismática, a pregação, a práxis libertadora e a Igreja plural, fragmentada e pós-moderna (Ver Capítulo 4, p. 68).

25 Tais notícias, que nem sempre entram na edição (foram encontradas apenas duas na amostra analisada), aparecem sempre no terceiro bloco do jornal, na editoria de Geral.
} 
correspondentes, das emissoras da própria RCR em diversas capitais brasileiras, informa os ouvintes sobre os destaques do dia em suas regiões. O radiojornal é encerrado, diariamente, com o comentário de um dos editorialistas ${ }^{26}$ que integram a equipe, opinando sobre algum dos temas principais do dia.

O Jornal Canção Nova $2^{a}$ Edição, transmitido de segunda a sexta, das 12 horas às $12 \mathrm{~h} 30^{27}$, foi o escolhido na Rádio Canção Nova. O radiojornal aborda também os principais fatos do dia em termos de Política, Economia, Internacional, Esportes, Geral e notícias sobre a Igreja Católica no Brasil e no mundo. Diferentemente do radiojornal da Aparecida, na Canção Nova não existem editoriais e as notícias sobre a Igreja (foram encontradas 14 notícias na amostra analisada) são apresentadas no início de cada edição, abordando sempre os pronunciamentos e a agenda do papa, além de outros fatos relacionados ao universo católico.

Como já exposto, dada a expressiva representatividade das emissoras católicas de rádio no País, tanto em termos numéricos quanto de alcance e influência no território nacional, julga-se relevante lançar luzes sobre a veiculação da informação jornalística nesse segmento, fato que, de forma geral, tem merecido pouca atenção nos meios acadêmicos. Assim, a pesquisa busca contribuir para o aprofundamento da compreensão sobre essa realidade.

\footnotetext{
${ }^{26}$ Mais frequentemente, os padres César Moreira, diretor da Rádio e TV Aparecida, e Jesus Flores, comentarista da Rádio Difusora de Goiânia, emissora também pertencente à congregação redentorista. Na amostra selecionada, os editoriais Nunca Antes na História Deste País, no dia 30/07/2012 e outro no dia 31/08/2012, abordando a Lei de Logística Reversa, que deverá ser implantada em 2014, são de autoria do padre Evaldo Cesar, apresentador da Rádio e da TV Aparecida, respectivamente dos programas A Igreja Somos Nós e BemVindo, Romeiro.

${ }^{27}$ No início desta pesquisa, o jornal era transmitido de segunda a sexta, das 13 horas às $13 \mathrm{~h} 30$, conforme indicado anteriormente.
} 


\section{A Igreja Católica e os Meios de Comunicação}

A Igreja Católica sempre acompanhou os meios de comunicação com grande interesse, seja adotando uma postura cautelosa e de vigilância em relação a eles, seja reconhecendo seu potencial como poderosos aliados na obra de evangelização e na atividade pastoral. As orientações e diretrizes divulgadas pelo Vaticano e pelos conselhos episcopais católicos vêm demonstrando um progressivo reconhecimento dos meios de comunicação como eficientes instrumentos de divulgação de valores como a fé, a ética e a moral na visão da Santa Sé, assim como das teses e princípios que a instituição defende. Nesse processo, a Igreja frequentemente adotou posição crítica em relação a esses meios, alertando para os possíveis danos que podem causar e aos riscos que representam, caso sejam utilizados de forma lesiva e prejudicial, segundo seu ponto de vista.

Em seus documentos oficiais, a Igreja Católica revela estar paulatinamente despertando para o potencial dos meios de comunicação de massa como importantes ferramentas de divulgação da mensagem cristã. O esforço da instituição em ocupar esse espaço privilegiado incluiu a atualização de sua linguagem, a modernização de sua imagem e a capacitação e formação adequadas de seus quadros para que se possam criar pontes de diálogo com a sociedade, conquistar e reconquistar fiéis, em especial ante o avanço das igrejas de confissões evangélicas e neopentecostais, verificado a partir da segunda metade do século passado.

A análise do pensamento comunicacional da Igreja demonstra que, mesmo com certa lentidão, a instituição vai integrando à sua reflexão não apenas a necessidade da presença concreta nos meios de comunicação, como também a importância de explorar as modernas ferramentas tecnológicas na busca de divulgação institucional e no exercício da catequização. 


\subsection{Meios de comunicação e Igreja: uma relação em desenvolvimento}

As orientações e diretrizes oficiais da Igreja Católica sobre a comunicação provêm, de forma geral, dos documentos oficiais do Vaticano, como cartas encíclicas, decretos e instruções pastorais sobre o tema, além das mensagens anuais da Santa Sé para o Dia Mundial das Comunicações Sociais, instituído pelo Concílio Vaticano II (1962-1965). De modo mais específico, encontram-se essas orientações nos documentos emitidos pelos conselhos episcopais da Igreja Católica nas diversas regiões e países. Na América Latina, essa instância colegiada é o Conselho Episcopal Latino-Americano (Celam) e, no Brasil, a Conferência Nacional dos Bispos do Brasil (CNBB).

Ao se examinarem os documentos eclesiais, pode-se considerar que, de maneira geral, ao longo da História, a Igreja Católica passou de uma posição reativa e normativa para um posicionamento cada vez mais receptivo e positivo em relação aos meios de comunicação, chegando a reconhecê-los, já em meados do século passado, como aliados imprescindíveis na missão de evangelizar.

O professor titular da Escola de Comunicações e Artes da Universidade de São Paulo Ismar de Oliveira Soares (1988), que se dedicou ao estudo do discurso e da prática da comunicação por parte da Igreja Católica, registra que o jesuíta italiano Enrico Baragli, considerado uma das referências mais importantes entre os estudiosos da questão da comunicação católica, identificou 87 documentos oficiais sobre o tema, produzidos nos 1,5 mil anos que separam a época apostólica da criação da imprensa por Gutenberg (1450). Esses textos tinham por objetivo ditar normas para imperadores, reis, bispos e fiéis, a fim de orientálos sobre como se posicionar frente aos “escritos, livros e teatros” (SOARES, 1988, p.30).

Com o advento da imprensa, a atenção da Igreja Católica voltou-se para os meios de impressão. Em 1487, Inocêncio VIII publicou o Inter Multiplices (em português, Entre os Muitos), demonstrando preocupação com o novo recurso, que poderia ameaçar o controle eclesiástico sobre a produção cultural de seu tempo. Nesse período, a Igreja começou a estabelecer um controle cada vez mais rigoroso sobre os livros suspeitos de heresia, por meio de listas emitidas pelo tribunal da Inquisição. Em 1559, o papa Paulo IV publica o Indice 
Librorum Prohibitorum, lista de autores e livros que não podiam ser editados nem lidos, prática que somente seria abandonada durante o pontificado de Paulo VI (1963-1978).

A jornalista e professora da Faculdade Paulus de Tecnologia e Comunicação (Fapcom), de São Paulo, Joana Terezinha Puntel (1994, p.32), também especialista no tema da comunicação da Igreja Católica, mostra que a atitude da instituição frente aos meios de comunicação se baseou em princípios morais e atitudes defensivas até meados do século 19, quando em 1861, durante o pontificado de Pio IX (1846-1878), foi lançado o jornal oficial do Vaticano, L’Osservatore Romano. A primeira coletiva de imprensa de um pontífice a jornalistas só ocorreria em fevereiro de 1879, com o papa Leão XIII (1878-1903).

A autora destaca que Leão XIII avançou em relação aos antecessores, na aceitação da necessidade de se examinar o mérito de cada publicação. A atitude de cautela da Santa Sé, entretanto, manteve-se nas primeiras décadas do século 20, passando a incluir também as reflexões sobre os meios de comunicação de massa que surgiam: o cinema, o rádio e, posteriormente, a televisão. Segundo a jornalista Helena Corazza (2000, p.33), presidente da Signis Brasil, entidade que reúne os veículos de comunicação católicos do País, vencida a resistência diante dos meios de comunicação - que perdurou até o início do século 20 -, a Igreja Católica percebeu o valor e o potencial representados por um veículo como o rádio, inaugurando, em 12 de fevereiro de 1931, sua própria emissora, a Rádio Vaticano.

Em 1936, o papa Pio XI (1922-1939) publicou a primeira encíclica a tratar de um meio de comunicação de massa, a Vigilanti Cura (Cuidado Vigilante). No documento, o pontífice manifestava suas preocupações e orientações a respeito do cinema, que então ganhava estatura de indústria. Para Puntel (1994, p.35), a evolução desse meio de comunicação de massa no início do século 20 impressionou o papa, que se tornou pessoalmente interessado na recente invenção, exaltando o poder e o potencial da nova tecnologia, mas demonstrando preocupação em relação ao impacto psicológico e moral que poderia ter sobre os indivíduos e a sociedade.

A segunda encíclica sobre o tema promulgada no século 20, Miranda Prorsus (em português, Os Maravilhosos Progressos), sobre Cinema, Rádio e Televisão, pelo então papa Pio XII (1939-1958), em 1957, ampliou o pensamento da Igreja sobre os meios de comunicação, acrescentando às considerações do antecessor, Pio XI, algumas observações sobre os novos meios de massa, como o rádio e a televisão. A encíclica soma-se a mais de 60 
documentos e discursos de Pio XII sobre o tema. Em todos eles, argumenta a teóloga paulina Noemi Dariva, que reuniu no estudo Comunicação Social na Igreja: documentos fundamentais (2003) os principais documentos eclesiais sobre a comunicação, o papa evidencia seu interesse pelo tema, demonstrando uma postura em geral positiva para com o potencial desses meios e incentivando a Igreja a uma ação pastoral mais ativa na sua utilização (DARIVA, 2003, p.33).

Nas considerações específicas sobre o rádio, o pontífice declara que “o mais nobre serviço a que ele é chamado é o de ilustrar e educar o homem, dirigindo-lhe a mente e o coração para esferas do espírito cada vez mais altas”. Pio XII exalta as virtudes educativas do rádio, lembrando ao mesmo tempo as responsabilidades que ele envolve, "porque também ele, como as outras técnicas, pode ser empregado para o bem e para o mal” (PAPA PIO XII, Carta Encíclica Miranda Prorsus, 1957, n.114).

Dessa forma, o papa recomenda aos rádio-ouvintes uma "apurada escolha dos programas":

(...) A transmissão radiofônica não deve ser um intruso, mas um amigo que entra no lar, mediante convite consciente e livre. (...) As transmissões admitidas em nossa casa deverão ser apenas as portadoras de verdade e de bem, as que não distraem, antes, ajudam os membros da família ao cumprimento dos próprios deveres pessoais e sociais, e as que, se se trata de jovens e crianças, longe de prejudicar, revigoram e prolongam a obra somente educativa dos pais e da escola (Ibidem).

Entre os deveres do rádio-ouvinte, segundo a encíclica, está o de “dar a conhecer aos responsáveis dos programas os seus legítimos desejos e suas justas objeções”. Esse dever decorre, segundo o documento, da própria natureza do rádio, "que pode facilmente criar uma relação de sentido único, de quem transmite para quem escuta” (Ibid., n. 115).

Os rádio-ouvintes devem, portanto, colaborar na formação duma opinião pública esclarecida que permita exprimir, nas devidas formas, aprovações, encorajamentos e objeções, e contribuir para que o rádio, conformemente à sua missão educativa, se ponha a serviço da verdade, da moralidade, da justiça e do amor (Ibid., n. 120). 
No documento, o pontífice destaca as possibilidades que o meio oferece ao apostolado e conclama os religiosos e leigos a desenvolverem programas católicos radiofônicos: "Rogamovos, veneráveis irmãos, que aumenteis e aperfeiçoeis mais ainda, segundo as necessidades e possibilidades de cada lugar, as transmissões religiosas” (Ibid., n. 124). A encíclica defende que os organismos nacionais católicos tomem providências no que diz respeito ao desenvolvimento e coordenação dos programas religiosos em cada país e autoriza os bispos a promulgar normas oportunas, confiando a sua execução aos organismos nacionais respectivos.

Foi também Pio XII a fazer o primeiro pronunciamento a uma emissora de rádio, a Radio Audivisione Italia (RAI), durante visita de diretores e operários da emissora ao Vaticano, em 3 de dezembro de 1944. Na ocasião, o papa afirmou: "Pelo grau de aperfeiçoamento a que chegou, o rádio é uma obra-prima do espírito inventivo do homem, uma maravilha da técnica, um prodígio da criação artística” (apud CORAZZA, 2000, p.35). E o pontífice pede aos radialistas que se coloquem “a serviço da verdade, da dignidade da vida, da moralidade cristã, da justiça e do amor” (Ibidem).

\subsection{O Concílio Vaticano II e os novos tempos}

O posicionamento da Santa Sé em relação aos meios de comunicação foi significativamente modificado e ampliado pelo decreto Inter Mirifica (Entre as Maravilhas, em português), aprovado pelo Concílio Vaticano II (1962-1965), em 4 de dezembro de 1963. O decreto definiu que a Igreja Católica deveria divulgar uma instrução pastoral para tornar efetivos os princípios e normas relativos ao que chamou de "meios de comunicação social”28. Para tanto, foi proposta a criação de um secretariado mundial especializado nos meios de comunicação: o Pontifício Conselho para as Comunicações Sociais da Santa Sé, e de

\footnotetext{
${ }^{28}$ Convocado pelo papa João XXIII, o concílio ecumênico Vaticano II reuniu cerca de 2,5 mil religiosos católicos para discutir mudanças de liturgia e doutrina, visando adaptar o catolicismo à atualidade. Eles debateram temas como as liberdades dos padres, as posições com relação aos costumes sociais, os rituais das missas e a relação da Igreja com outras religiões. Os encontros resultaram numa série de diretrizes documentadas em quatro constituições, três deliberações e nove decretos. Após a morte do papa João XXIII, em junho de 1963, as reuniões passaram a ocorrer sob a liderança do papa Paulo VI (1963-1978).
} 
secretariados nacionais de imprensa, cinema, rádio e televisão, com a função principal de "unificar os esforços, formar as consciências, orientar e proteger tudo o que for feito nesse setor pelos católicos” (CONCÍLIO VATICANO II, Decreto Inter Mirifica, 1963 n. 21) ${ }^{29}$.

Puntel (2011) assinala que, por meio do Inter Mirifica, pela primeira vez a Igreja defende o direito e determina a obrigação de a instituição utilizar os meios de comunicação social a serviço de sua missão:

\begin{abstract}
A Igreja Católica, tendo sido constituída por Cristo Nosso Senhor, a fim de levar a salvação a todos os homens e, por isso, impelida pela necessidade de evangelizar, considera como sua obrigação pregar a mensagem de salvação, também com o recurso dos instrumentos de comunicação social, e ensinar aos homens seu correto uso. Portanto, pertence à Igreja o direito natural de empregar e possuir toda sorte desses instrumentos, enquanto necessários e úteis à educação cristã e a toda a sua obra de salvação das almas... (CONCÍLIO VATICANO II, Decreto Inter Mirifica, 1963, n. 3).
\end{abstract}

A autora destaca, ainda, como maior contribuição do Inter Mirifica, a sua defesa sobre o direito de informação dos cidadãos:

É intrínseco à sociedade humana o direito à informação sobre aqueles assuntos que interessam aos homens e às mulheres, quer tomados individualmente, quer reunidos em sociedade, conforme as condições de cada um (Ibidem).

Por ocasião do $5^{\circ}$ Dia Mundial das Comunicações, no dia 23 de maio de 1971, o Pontifício Conselho para as Comunicações Sociais promulgou a instrução pastoral Communio et Progressio (Comunhão e Progresso), que enfatiza, já em seu primeiro parágrafo, que “a

${ }^{29}$ Uma das decisões do concílio foi a inclusão, no calendário da Igreja Católica, do Dia Mundial das Comunicações Sociais. A intenção foi a de criar um dia de orações, estudos e reflexões sobre algum aspecto dos ensinamentos da Igreja a respeito da comunicação. Desde 1967, o papa publica anualmente, no dia 24 de janeiro, Dia de São Francisco de Sales, considerado o padroeiro dos jornalistas, uma mensagem relativa ao tema escolhido a cada ano. 
comunhão e o progresso da convivência humana são os fins primordiais da comunicação social e dos meios que emprega, como a imprensa, o cinema, o rádio e a televisão" (PONTIFÍCIO CONSELHO PARA AS COMUNICAÇÕES SOCIAIS, Instrução Pastoral Communio et Progressio, 1971, n. 1).

A instrução é considerada um dos documentos mais positivos da Igreja sobre o tema, ao voltar a atenção sobre como os meios de comunicação podem contribuir para o progresso da humanidade, enquanto, anteriormente, a preocupação era normatizar, focando os direitos e deveres da Igreja e dos católicos em relação a esses meios. Para Dariva (2003), a Communio et Progressio pode ser considerada a carta magna da comunicação cristã, caracterizando-se por apresentar uma aproximação mais positiva e profissional entre a Igreja e os meios de comunicação. Pela primeira vez, segundo a autora, um documento sobre a comunicação na Igreja resulta do trabalho de uma equipe de vários profissionais especializados, reunidos pelo Pontifício Conselho para as Comunicações Sociais, e oferece tópicos para uma série de reflexões e discussões posteriores.

Outra instrução que se tornou referência sobre a posição da Igreja Católica em relação à comunicação foi a Aetatis Novae (Nova Idade), lançada em 1992, também pelo Pontifício Conselho para as Comunicações Sociais, por ocasião do vigésimo aniversário de lançamento da Communio et Progressio. O planejamento e preparação pastorais são vistos com especial interesse, e o documento propõe a elaboração de planos estratégicos de trabalho para as pastorais de comunicação.

Em 4 de junho de 2000, o conselho publicou o documento Ética nas Comunicações Sociais, com a preocupação de lançar luzes sobre as possibilidades e desafios para os comunicadores no limiar no novo milênio. A reflexão incorpora a nova realidade criada por fenômenos como a globalização, como as políticas do neoliberalismo, a sociedade de consumo, a informação instantânea trazida pela internet e os dilemas próprios de uma época marcada por grandes questionamentos morais e éticos.

No documento, a Igreja reafirma os benefícios que os meios de comunicação podem trazer nos seguintes termos: econômicos, como o estímulo aos negócios e ao progresso; políticos, como o esclarecimento da população e o fortalecimento da democracia; culturais, como o acesso de um contingente cada vez maior de pessoas às artes; educativos, ao levar 
conhecimento às áreas mais remotas do planeta; e religiosos, podendo contribuir para o enriquecimento espiritual do ser humano. Mas alerta para os perigos representados pela exclusão econômica e social, pela manipulação política da opinião pública e pela “dominação cultural que leva à uniformidade e ao enfraquecimento das culturas locais, bem como ao fanatismo e à hostilidade religiosos que esses meios podem fomentar ou acentuar" (PONTIFÍCIO CONSELHO PARA AS COMUNICAÇÕES SOCIAIS, Ética nas Comunicações Sociais, 2000, n. 6-12).

[...] Os meios de comunicação podem reduzir os seres humanos a unidades de competição entre si, ou manipular telespectadores, leitores e ouvintes como meras cifras das quais se esperam vantagens, quer elas sejam relacionadas com um apoio do tipo político ou com a venda de produtos; são esses fatos que destroem a comunidade. A comunicação tem a tarefa de unir as pessoas e de enriquecer a sua vida, e não de isolá-las e explorá-las. Se forem usados de maneira correta, os meios de comunicação social podem contribuir para criar e manter uma comunidade humana baseada na justiça e na caridade e, à medida que o fizerem, tornam-se sinais de esperança (Ibidem, n. 19).

Alguns princípios éticos fundamentais na prática da comunicação apontados pelo documento são: “A busca da verdade, o equilíbrio entre lucro e interesse público, a promoção da solidariedade, a defesa da justiça e da liberdade” (Ibid., n. 20). De modo simultâneo, os profissionais da comunicação devem, segundo o documento, procurar combater males como a pobreza, o analfabetismo, a repressão política e as violações dos direitos humanos, assim como conflitos entre grupos étnicos e religiosos e a supressão das culturas indígenas.

\subsection{Documentos das Conferências Gerais do Episcopado Latino-Americano e Caribenho}

Os textos oficiais da Igreja Católica na América Latina e no Brasil sobre a utilização dos meios de comunicação refletem, de maneira geral, as posições da Santa Sé em relação ao tema. Quando esses são utilizados de forma positiva, é perfeitamente lícito e até desejável que 
sejam incorporados à ação evangelizadora. Mas, ao alertarem para um eventual uso desses meios de forma negativa, as instituições eclesiais regionais adotam uma postura ainda mais acentuadamente crítica que a do Vaticano.

Entre os documentos que abordaram a relação da Igreja com os meios de comunicação na América Latina destacam-se os produzidos ao final das Conferências Gerais do Episcopado Latino-Americano e Caribenho, realizadas em Medellín, na Colômbia (1968), em Puebla, no México (1979), Santo Domingo, na República Dominicana (1992) e Aparecida, Brasil (2007). Os documentos finais das conferências mostram, de uma maneira geral, grande preocupação de seus representantes com problemas atávicos dessa região, como as desigualdades econômicas e sociais, as violações aos direitos humanos, a violência do tráfico, a exploração sexual e a marginalização dos povos indígenas, ao mesmo tempo em que delineiam e reiteram sua “opção pelos pobres”. Os bispos latinoamericanos encaram a ação dos meios de comunicação como um fenômeno também dicotômico, na medida em que acreditam que esses têm o potencial de atuar na promoção da educação e cidadania, mas ao mesmo tempo podem intensificar os efeitos de fenômenos negativos, como o consumismo exacerbado, e contribuir para a supressão das identidades regionais, por meio da ação hegemônica dos grandes conglomerados, propiciada pelo fenômeno da globalização.

\subsection{Documentos da Conferência Nacional dos Bispos do Brasil (CNBB)}

A Conferência Nacional dos Bispos do Brasil (CNBB) lançou, em 1997, após sua 35a Assembleia Geral, realizada em Indaiatuba (SP), o Documento $n^{\circ} 59$, o primeiro da entidade totalmente voltado para o tema da comunicação, intitulado Igreja e Comunicação Rumo ao Novo Milênio: Conclusões e Compromissos. Em janeiro de 2011, durante reunião da Pastoral da Comunicação (Pascom) da CNBB, realizada em Brasília, foi lançado o Estudo $n^{\circ}$ 101, com o título A Comunicação na Vida e Missão da Igreja no Brasil.

Tanto no Documento 59 e quanto no Estudo 101, a CNBB procurou estabelecer as diretrizes que devem nortear a ação da Igreja no País no setor de comunicação. Neles, os bispos brasileiros retomam a visão de ambivalência que marca os documentos eclesiais em 
relação aos meios de comunicação, admitindo que esses podem ter impactos positivos ou negativos, dependendo do modo como são utilizados.

No Documento 59, o episcopado brasileiro orienta a ação da pastoral da comunicação nas dioceses e paróquias que, segundo a CNBB, deve ser “dialógica”, isto é, um processo de dupla via. A publicação lança as diretrizes das práticas de comunicação da Igreja no Brasil, tanto no campo das relações interpessoais e organizacionais, quanto no uso dos instrumentos ou meios na tarefa evangelizadora. O documento também apresenta orientações sobre o relacionamento da Igreja com a imprensa e a presença da instituição na internet.

Uma parte da publicação é dedicada às diretrizes de atuação em relação às rádios comerciais, educativas e comunitárias. A CNBB demonstra interesse em priorizar o rádio como instrumento de evangelização - ocupando os espaços disponíveis nas emissoras locais e dotando as cúrias de estúdios de gravação -, assim como em estimular a ação das associações e redes de rádios católicas já existentes, ao mesmo tempo em que incentiva a formação de novas associações e redes.

O Estudo 101, lançado no início de 2011, aprofunda a temática da nova cultura midiática e do uso das novas tecnologias para promover a evangelização e a fé nos novos tempos. O capítulo IV se ocupa da chamada "urgência educativa” para as novas mídias, e defende que essa educação se faça por meio de três atividades: “A vivência do processo comunicativo, a capacitação para a produção de conteúdos e a formação para a análise crítica dos processos de comunicação e das produções midiáticas” (CNBB, 2011, p.57).

O tema da pastoral da comunicação e da presença da Igreja na mídia ocupa os cinco capítulos seguintes, finalizando, no capítulo IX, com o planejamento da comunicação e a importância de se definirem prioridades para alcançar os resultados pretendidos. O capítulo defende a integração das ações de comunicação no contexto do planejamento geral da pastoral, convidando a comunidade eclesial a pensar estrategicamente. O estudo é o embrião do que deverá tornar-se o primeiro diretório de comunicação da Igreja Católica no Brasil. 
Segundo o então presidente da Comissão Episcopal Pastoral para a Educação, Cultura e Comunicação Social da $\mathrm{CNBB}^{30}$ e atual arcebispo do Rio de Janeiro, dom Orani João Tempesta, responsável pela elaboração do documento, “essa foi uma resposta à necessidade da Igreja no Brasil em trabalhar com o apoio de um subsídio sobre comunicação em nosso país e tem por objetivo ser um animador e orientador para essa atividade”. Em entrevista ao portal da CNBB no dia 24 de janeiro de $2011^{31}$, data em que foi lançado o estudo, dom Orani destaca que a preocupação do texto é ser colocado à disposição da Igreja e de seus integrantes para que seja debatido e aprofundado, a fim de futuramente resultar no diretório de comunicação. “A comunicação é essencial na vida do ser humano e a Igreja é feita de comunicação”, afirma o arcebispo.

O texto final do diretório, que passa por uma fase de finalização, deverá ser submetido à aprovação do Conselho Permanente da CNBB ainda em $2013^{32}$.

\subsection{A presença da Igreja Católica no rádio}

Conforme observado, a Igreja Católica sempre mostrou certa resistência à chegada das novas tecnologias de comunicação. Em relação ao rádio, a instituição passou a marcar presença na primeira mídia eletrônica de massa a partir da criação da Rádio Vaticano, em 12 de fevereiro de 1931. No Brasil, os primórdios da comunicação sonora à distância remetem às pesquisas do padre católico gaúcho Roberto Landell de Moura que, em 1883, segundo notícias de jornais da época, realizou a primeira transmissão pública do mundo. Sua voz,

\footnotetext{
${ }^{30}$ Em maio de 2010, durante a $49^{\text {a }}$ Assembleia Geral dos Bispos do Brasil, foi criada a Comissão Episcopal Pastoral para a Comunicação da CNBB, sob a liderança de dom Dimas Lara Barbosa, ex-secretário-geral da entidade e atual arcebispo de Campo Grande.
}

31 Disponível em http://www.cnbb.org.br/site/imprensa/noticias/5686-lancado-documento-de-estudo-acomunicacao-na-vida-e-na-missao-da-igreja-no-brasil Acesso em 15 de abril de 2011.

32 Segundo afirmou, em entrevista à autora, dom Dimas Lara Barbosa, presidente da Comissão Episcopal Pastoral para a Comunicação. A entrevista foi realizada no dia 8 de fevereiro de 2013, em São Paulo (APÊNDICE H). 
emitida de um aparelho da Avenida Paulista, em São Paulo, percorreu oito quilômetros e pôde ser ouvida em um aparelho receptor no bairro de Santana (CORAZZA, 2000 e FERRARETO, 2001).

Apesar de ter antecedido em mais de uma década as descobertas do italiano Guglielmo Marconi, aclamado como inventor do rádio, após realizar as primeiras transmissões em 1896, Landell de Moura não pôde contar nem com o apoio do governo brasileiro nem da Igreja Católica, que procurou coibir as, assim consideradas, “excentricidades” do sacerdote.

No Brasil, o meio só teria sua primeira transmissão oficial durante as comemorações do Centenário da Independência, no Rio de Janeiro, em setembro de 1922, sendo implantado com cunho educativo e cultural por representantes da elite econômica e intelectual. Já na década seguinte, em função do desenvolvimento de recursos técnicos como as ondas curtas, o rádio conquistava audiências cada vez maiores, passando a operar em redes nacionais.

Na era Vargas (1930-1945) é propagada, por meio das emissões radiofônicas, a ideia da união territorial e da criação de uma identidade nacional (SILVA, 2005). Em 1939, foi criado o Departamento de Imprensa e Propaganda (DIP), que tinha por objetivo, entre outros, organizar um programa de rádio diário veiculado obrigatoriamente em todo o território nacional, A Hora do Brasil.

Data desse período a primeira concessão de rádio de que se tem registro à Igreja Católica no País: em 1941, com a outorga da Rádio Excelsior da Bahia pelo governo Vargas aos padres franciscanos liderados pelo frade Hildebrando Kruthaup. A emissora entrou no ar em 5 de julho de 1942. Segundo Corazza (2004), entre as primeiras emissoras católicas do Brasil estão: Rádio Xavantes, Iparemi (GO), inaugurada em 25 de dezembro de 1947 (em 76 passou aos padres redentoristas); Rádio Manhuaçu (MG), em 19 de outubro de 1950 (pertencente aos padres sacramentinos de Nossa Senhora); Legendária, Lapa (PR), em 25 de novembro de 1950; Difusora, Machado (MG), em 18 de maio de 1951; Rádio Aurora, Guaporé (RS), em 7 de setembro de 1951 (padres carlistas); Rádio Aparecida, Aparecida (SP), em 8 de setembro de 1951 (padres redentoristas) ${ }^{33}$; Rádio Cristal, de Soledade (RS), em 18 de outubro de 1951

\footnotetext{
${ }^{33}$ A autora lembra que o Santuário de Aparecida já havia sido palco de uma transmissão conjunta das rádios Difusora e Record, em 1935, despertando grande interesse por parte dos fiéis e dando início aos esforços dos padres redentoristas para conseguir uma concessão para o Santuário (CORAZZA, 2004, p. 265).
} 
(padres da ordem franciscana dos capuchinhos); e Rádio Cacique, de Lagoa Vermelha (RS), em 26 de maio de 1948 (em 53, passou também aos padres capuchinhos).

O frei Clarêncio Neotti, estudioso da comunicação da Igreja no Brasil, cita cinco fatores que fizeram a instituição entrar no mundo da radiodifusão sonora: a intenção de fazer do rádio o prolongamento do púlpito; a importância do rádio como meio popular de comunicação, especialmente a partir da chegada do transistor (1948); a concorrência com protestantes e espíritas, que cada vez mais faziam uso do rádio; a relativa facilidade de conseguir concessões junto ao governo, dada a ação tradicionalmente educativa e cultural da Igreja; e o baixo custo relativo para a montagem de uma emissora (NEOTTI, 1994, p.70).

Soares aponta a proliferação de seitas e novas religiões como um dos principais motivadores da Igreja Católica em investir nos meios de comunicação:

Ao lado da imprensa, o rádio surgiu, entre 1940 e início dos anos 60, como a nova e grande arma das campanhas e cruzadas, tanto para a evangelização, quanto para alfabetização do povo. (...) O importante, contudo, não era apenas possuir emissoras de rádio, mas impedir que os "inimigos da fé" as adquirissem ou fizessem uso do veículo (SOARES, 1988, p. 254).

As décadas de 1950 e 1960 também registraram um grande número de concessões para a Igreja Católica, grande parte em virtude de as rádios católicas terem desenvolvido projetos de educação e alfabetização, com destaque para o Movimento de Educação de Base (MEB), em parceria com o governo brasileiro. Esse projeto teve sua ação bastante limitada a partir do golpe militar de 1964, com o consequente aumento da repressão política. O movimento teve diversas de suas sedes invadidas, sofreu destruição de material, ataques ideológicos e restrição progressiva, assumindo nova orientação a partir de 1984.

Outro evento político que marcou a radiodifusão católica no Brasil foi o fechamento da Rádio Nove de Julho, da Arquidiocese de São Paulo, em 30 de outubro de 1973, por decreto do governo Médici, em virtude da atuação do responsável pela rádio, o arcebispo de São Paulo, dom Paulo Evaristo Arns, em defesa dos direitos humanos. A emissora só seria devolvida 25 anos depois. 
Até finais da década de 1970, as rádios católicas trabalharam em geral de forma isolada, sem a preocupação de profissionalizarem-se ou de planejarem ações de forma conjunta e continuada, no contexto de um grande projeto de evangelização, lembra Corazza (2000, p.41). Em 1976, as rádios organizaram-se em uma associação: a União de Radiodifusão Católica do Brasil (Unda/BR), que representava no País a União de Radiodifusão Católica (Unda), entidade internacional de comunicação ligada ao Vaticano.

Atualmente, as entidades católicas de comunicação reúnem-se numa única associação, a Signis Mundial, fundada em 2001, com a fusão da Organização Católica Internacional de Cinema e da Unda. Por sua vez, a Signis Brasil, criada em 2010, passou a integrar as instituições e profissionais de comunicação católicos nas áreas de publicações impressas, rádio, cinema, internet, TV e institutos de formação, capacitação e ensino superior.

A primeira tentativa de organização em rede das emissoras católicas ocorreu em 1959, com a criação, por parte da CNBB, da Representação Nacional de Emissoras Católicas (Renec). Outra tentativa foi propiciada pelo MEB, programa de alfabetização que surgiu da experiência das escolas radiofônicas criadas por dom Eugênio Sales, então arcebispo de Natal, em 1957. O programa foi implementado a partir de 1961. Em 1988, a Rádio Aparecida criou a Rede Azul e Branca, transmitindo diariamente o Jornal dos Jornais juntamente com emissoras de Minas Gerais e do Nordeste.

A partir de 1993, as rádios católicas reuniram-se na Rede Católica de Rádio (RCR), que gera via satélite as transmissões de eventos nacionais. As emissoras que formam a RCR estão agrupadas em redes regionais, algumas das quais são bases geradoras do grupo maior. São elas: Rádio Aparecida (Aparecida, SP, com 80 emissoras) e Difusora (Goiânia, GO, 22 emissoras), ambas pertencentes aos missionários redentoristas; Rede Canção Nova (Cachoeira Paulista, SP, com 28 emissoras), ligada ao movimento da Renovação Carismática Católica; Rede Milícia Sat (Santo André, SP, com 82 emissoras), dos Missionários da Imaculada; e Rede Brasil Sul de Comunicação (Caxias do Sul, RS, 9 emissoras), dos frades capuchinhos.

A rede católica reúne pelo menos 200 emissoras transmitindo diariamente o Jornal Brasil Hoje (JBH), produzido pela Rádio Aparecida em conjunto com outras emissoras associadas. O radiojornal é transmitido de segunda a sábado, das 7 horas às 7 h30, simultaneamente pelas 
emissoras ligadas à RCR, e apresenta os principais destaques nacionais, internacionais, além de notícias da Igreja Católica no Brasil e no mundo ${ }^{34}$.

Outros programas transmitidos simultaneamente pela rede são: o Plantão $R C R$ (de segunda a sexta, às 8h55, 9h55, 10h55, 13h55, 14 h55 e 15h55) e RCR em Debate (sábados, das 11 às 12 horas), também produzidos pela Rádio Aparecida; e os programas Palavra da CNBB (segunda a sexta, das $17 \mathrm{~h} 55$ às 18 horas), Igreja no Rádio (segunda a domingo, da meia-noite às 5 horas e das 20 horas à 1 hora), e a Consagração a Nossa Senhora (segunda a sábado, das 15 horas às 15h20), que são produzidos pela Rádio Milícia da Imaculada.

Essa configuração faz da Rede Católica de Rádio a maior rede do País ${ }^{35}$. Segundo o estudo Tudo o que Você Precisa Saber Sobre Rádio e Televisão, versão 2012, da Associação Brasileira de Emissoras de Rádio e Televisão (Abert) ${ }^{36}$, as 10 principais redes de rádio AM/FM do Brasil são: Jovem Pan Sat AM, com 81 emissoras; Jovem Pan Sat FM, com 58 emissoras; Rede Transamérica Hits (55); Rede Bandeirantes AM/FM (51); Rede Band FM (38); Globo AM (32); Rede Mix FM (22); CBN (20) e Rede Estadão/ESPN (20).

A Rede Gaúcha SAT, ligada à Rádio Gaúcha (Grupo RBS), que não aparece nesse estudo, é integrada por 160 emissoras, distribuídas por sete estados brasileiros. A título de comparação com as emissoras evangélicas, a Rede Aleluia, da Igreja Universal do Reino de Deus, que também não consta do estudo, detém 72 emissoras em todas as regiões do Brasil ${ }^{37}$.

O portal Tudo Rádio.com, especializado em notícias sobre rádio, lista 158 emissoras evangélicas, cuja programação pode ser acessada on-line, das quais 42 são $\mathrm{FM}^{38}$. Segundo seu editor, Carlos Massaro ${ }^{39}$, o portal, que foi criado em 2003, disponibiliza links para pelo menos $90 \%$ das emissoras do segmento religioso.

\footnotetext{
${ }^{34}$ Disponível em http://rcr.org.br/paginas/ver/programacao-rcr. Acesso em 15 de janeiro de 2012.

${ }^{35}$ Para mais informações sobre como atua a Rede Católica de Rádio ver entrevista com o frei João Carlos Romanini, presidente da entidade realizada no dia 22 de fevereiro de 2013, em São Paulo (APÊNDICE G).

${ }^{36}$ Disponível em http://www.abert.org.br/site/index.php?/downloads/artigos/127-radiodifusaoumaabordagemnumericanova.html. Acesso em 15 de abril de 2013.

${ }^{37}$ Disponível em http://www.redealeluia.com.br/section_emissoras_3.php. Acesso em 20 de abril de 2013.

${ }^{38}$ Disponível em http://tudoradio.com/radios/subcategoria/16-evangelica. Acesso em 20 de abril de 2013.

${ }^{39}$ Em entrevista por telefone à autora no dia 23 de abril de 2013.
} 


\section{Jornalismo e Evangelização em Emissoras Católicas}

\subsection{A evangelização pelos meios de comunicação}

"Ide por todo o mundo e pregai o Evangelho a toda a humanidade" (Marcos, 16,15). Esse versículo do Evangelho Segundo São Marcos pode ser apontado como o princípio norteador da ação da Igreja Católica em relação à evangelização pelos meios de comunicação ${ }^{40}$. Conforme visto no capítulo anterior, a Igreja sempre acompanhou o universo da comunicação com grande interesse, seja, a princípio, adotando uma postura cautelosa e crítica em relação aos meios e veículos, seja, posteriormente, reconhecendo seu potencial como poderosos aliados na atividade pastoral.

Nesse processo, o conjunto de doutrinas, ensinamentos, orientações e diretrizes divulgados pelo Vaticano demonstram um progressivo reconhecimento desses meios como possíveis instrumentos da Igreja na divulgação de sua mensagem, de seus valores e de sua visão de mundo. Ao entrar no campo da comunicação, a Igreja teve e tem a evangelização como primeiro objetivo e, em seu esforço para ocupar esse espaço privilegiado, vem buscando criar pontes de diálogo com a sociedade, conquistar e reconquistar fiéis, em especial ante o avanço de outras denominações religiosas.

O consenso em torno do que se entende por evangelização, entretanto, não é estanque. Em um estudo sobre o radiojornalismo na Rádio Aparecida, seu então diretor, o padre redentorista César Moreira (1994) define o termo evangelização de quatro diferentes maneiras. Em primeiro lugar, essa atividade, pode ser entendida como “o anúncio da Boa Notícia de Jesus”, que prega a caridade, o amor fraternal e a igualdade dos homens perante Deus. Uma segunda definição mostra que evangelizar também é "realizar a Boa Notícia de Jesus e de seu projeto histórico”, que se expressa, segundo o autor, na formação de uma comunidade a partir da conversão e da renúncia aos bens materiais. Um terceiro conceito compreende a

\footnotetext{
40 Houaiss define evangelização como “1. REL. ato, processo ou efeito de evangelizar, de difundir os ensinamentos do Evangelho. 2. p. ext. fig. Ato, processo ou efeito de difundir doutrina, sistema ou conjunto de ideias" (HOUAISS, 2001, p. 1.277).
} 
evangelização como a ação pela qual a Igreja anuncia a "Boa Nova do Evangelho", por meio do testemunho, propondo “adesão de coração e conversão de vida”. Um quarto conceito caracteriza a evangelização como o processo de "converter para o Evangelho, chamando o interlocutor a aderir a uma comunidade de fé na qual se destacam os valores humanos e cristãos” (MOREIRA, 1994, pp. 28-31).

Essa síntese está baseada no documento Evangelii Nuntiandi (O Anúncio do Evangelho), divulgado pelo papa Paulo VI em 1975, após o sínodo (assembleia eclesiástica) dos bispos realizado em Roma sobre o tema A Evangelização no Mundo Contemporâneo. O documento reunia tudo o que se tinha de reflexão sobre o tema até então e lançava novas reflexões frente aos desafios do mundo moderno. Nele, o papa destacava a importância dos meios de comunicação como uma “versão moderna do púlpito”, exortando os seus agentes a utilizá-los na propagação de sua mensagem: "Postos a serviço do Evangelho, tais meios são susceptíveis de ampliar, quase até o infinito, o campo para poder ser ouvida a Palavra de Deus e fazem com que a Boa Nova chegue a milhões de pessoas”, diz o papa no capítulo IV, dedicado aos métodos e meios de evangelização (PAPA PAULO VI, Evangelii Nuntiandi, 1975, n. 45).

Desde 1967, quando foi instituída a celebração do Dia Mundial das Comunicações Sociais no calendário da Igreja Católica, os sumos pontífices publicam no dia 24 de janeiro, Dia de São Francisco de Sales, padroeiro dos jornalistas, uma mensagem que diz respeito a um tema relativo à comunicação. A intenção é lançar uma reflexão sobre algum aspecto dos ensinamentos da Igreja com relação ao tema. Em 1974, na mensagem intitulada As Comunicações Sociais e a Evangelização no Mundo Contemporâneo, Paulo VI lembrou que “a evangelização é parte constitutiva da missão da Igreja” e que essa deve esforçar-se para cumpri-la por todos os caminhos e por todos os meios dos quais pode usufruir, tendo sempre em vista "os conceitos de dignidade da pessoa humana, de justiça e de fraternidade universal” (Idem, 1974).

Na mensagem As Comunicações Sociais a Serviço da Liberdade Responsável do Homem (1981), o papa João Paulo II (1978-2005) também abordou o tema da evangelização pela comunicação, advertindo para a necessidade da formação de uma consciência crítica sobre os meios: 
É preciso que se intensifique a ação direta na formação de uma consciência "crítica”, que incida sobre as atitudes e os comportamentos não somente dos católicos ou dos irmãos cristãos - defensores, por convicção ou por missão, da liberdade e da dignidade da pessoa humana -, mas de todos os homens e mulheres, adultos e jovens, para que saibamos verdadeiramente "ver, julgar e agir” como pessoas livres e responsáveis, também (...) na produção e nas escolhas que digam respeito aos meios de comunicação social (PAPA JOÃO PAULO II, 1981, n. 6).

Em 1987, o tema escolhido pelo pontífice para a mensagem foi Comunicações Sociais $e$ Promoção da Justiça e da Paz, na qual afirma que “a informação é o caminho da sensibilização, da verificação e do controle da realidade dos fatos nos caminhos da paz" (Idem, 1987, n. 13).

Em 1997, João Paulo II elegeu o tema Comunicar o Evangelho de Cristo: Caminho, Verdade e Vida, em que convida a Igreja a refletir acerca do lugar que a mensagem cristã pode ocupar nos meios de comunicação e procura motivar os profissionais de comunicação a refletirem sobre como os temas e valores religiosos podem “enriquecer” a mídia e os que a sua produção alcança.

João Paulo II faria menção específica ao jornalismo e seu “dever de defender a liberdade, a justiça e a verdade” na mensagem Os Meios de Comunicação a Serviço da Paz Autêntica, à Luz da Pacem in Terris, de 2003, afirmando: “Os jornalistas (...) têm o grave dever de seguir as instâncias da sua consciência moral e de resistir às pressões de 'adaptar' a verdade para satisfazer as exigências da riqueza ou do poder político” (Idem, 2003, n. 5). No documento, o papa defende o ponto de vista de que "somente se tiverem acesso livre às informações verdadeiras e suficientes, é que as pessoas poderão procurar o bem comum e considerar as autoridades públicas responsáveis”, conclamando os meios de comunicação a servir às verdadeiras necessidades e interesses da sociedade (Ibidem).

A utilização dos meios de comunicação para a atividade de evangelização fora abordada em profundidade pelo pontífice anteriormente, na encíclica Redemptoris Missio (A Missão do Redentor), de 1990, na qual se referia aos meios de comunicação como “o areópago dos tempos modernos”. Para o papa, esses já haviam alcançado tamanha importância que haviam se tornado para muitos "o principal instrumento de informação e formação, de guia e inspiração dos comportamentos individuais, familiares e sociais”. Fazendo uma analogia com 
a pregação do apóstolo Paulo no areópago de Atenas, o papa afirmava que se deveria proclamar o Evangelho usando uma linguagem adaptada e compreensível a cada contexto e cultura, defendendo que a Igreja integrasse sua forma de comunicar à nova cultura midiática: “Não é suficiente, portanto, usá-los [os meios de comunicação] para difundir a mensagem cristã e o Magistério da Igreja, mas é necessário integrar a mensagem nesta nova cultura” (Idem, 1990, n. 37).

Na América Latina, o estudo da evangelização ganhou destaque com a II Conferência Geral do Episcopado Latino-Americano, realizada em Puebla, no México, em 1979, constituindo a primeira síntese do pensamento da Igreja latinoamericana sobre a questão. $\mathrm{O}$ tema da conferência foi A Evangelização no Presente e no Futuro da América Latina, e levou os bispos a refletirem sobre uma visão regional de evangelização, incluindo nessa reflexão o emprego dos meios de comunicação como agentes da comunhão e de participação, assim como sua inter-relação com a realidade sociocultural e econômica da região. Segundo o documento de Puebla, “a evangelização, anúncio do Reino, é comunicação”, mas é também denúncia:

Evangelizar significa anunciar Jesus Cristo e sua Boa Notícia onde a realidade vigente traduz exatamente o contrário. Isso quer dizer chegar a atingir e modificar pela força do Evangelho os critérios de juízo, os valores que contam os centros de interesses, as linhas de pensamento, as fontes inspiradoras e os modelos de vida de comunidade que se apresentam em contraste com a Palavra de Deus (CELAM, 1979, Documento de Puebla, n.1063).

Para Moreira (1994), o documento de Puebla - fortemente influenciado pela Teologia da Libertação que se desenvolvia na América Latina - conclui que são elementos integrantes da evangelização: a promoção humana em seus aspectos de desenvolvimento e libertação, a defesa da conduta social cristã, a promoção da justiça, a educação do homem, a ação de serviço; e, como elemento indispensável para evangelizar, o autor aponta o "dever da denúncia”, essa última entendida como a análise crítica de todo o processo comunicativo, denunciando o controle, o monopólio e a manipulação dos meios (Ibidem, p. 31). O documento de Puebla afirma: “A Igreja, no uso dos meios próprios, deve ser cada dia mais a voz dos desamparados, apesar dos riscos que isto implica” (Ibid., n.1063). 
Os documentos divulgados após as conferências de Santo Domingo, na República Dominicana (1992), e em Aparecida, São Paulo (2007), aprofundam a necessidade do impulso evangelizador utilizando os meios de comunicação no continente e buscam estabelecer as diretrizes de uma pastoral da comunicação em conformidade com a realidade regional e as potencialidades trazidas pelos avanços tecnológicos e as redes sociais.

No Brasil, a Conferência Nacional dos Bispos do Brasil (CNBB), estabeleceu as bases que devem nortear a ação da Igreja Católica na ação evangelizadora, em paralelo às diretrizes do Vaticano e às discussões das Conferências Episcopais Latino-Americanas. Em 1989, a CNBB promoveu uma Campanha da Fraternidade sobre o tema Comunicação para a Verdade e a Paz, elegendo a pastoral da comunicação como uma das prioridades da ação da Igreja no País, estabelecendo que, nos anos seguintes, fossem criadas pastorais específicas para a comunicação em cada uma das paróquias brasileiras.

No documento Diretrizes Gerais da Ação Pastoral da Igreja no Brasil (1991-1994), a Igreja Católica reconhecia que já não se apresentava diante do povo como a instituição-mestra na orientação dos valores formadores da sociedade brasileira. Outros interlocutores, entre eles os meios de comunicação social, eram reconhecidos como sérios concorrentes. "A Igreja no Brasil foi aos poucos descobrindo os meios de comunicação como espaços de evangelização” (DARIVA, 2003, p.515). A autora destaca, ainda, que o problema da diminuição em larga escala de católicos praticantes levou algumas lideranças católicas a entenderem ser necessário voltarem-se para o mundo das comunicações, adaptando para o campo da evangelização conceitos e procedimentos próprios do mundo do mercado publicitário.

Por meio da coleção Documentos da CNBB, publicada pela editora Paulinas, os bispos brasileiros têm demonstrado sua disposição em fazer com que os meios de comunicação - e, mais recentemente, as novas tecnologias - sejam valorizados e usados na ação evangelizadora. No documento de número 59, intitulado Igreja e Comunicação Rumo ao Novo Milênio - Conclusões e Compromissos e lançado após a 35 a Assembleia Geral da CNBB, em Indaiatuba (SP), no mês de abril de 1997, os bispos orientam a ação da pastoral da comunicação nas dioceses e paróquias e apresentam orientações sobre a utilização pela Igreja dos meios de comunicação e da internet (ver Capítulo 2, pp. 34-36). 
O Estudo 101 (ver Capítulo 2, p. 35), publicado em 2011 pela CNBB com o objetivo de servir de base para o primeiro diretório de comunicação da Igreja no Brasil, amplia a reflexão sobre uma evangelização coerente com as necessidades dos dias de hoje, procurando entender a comunicação como experiência de vida originada "a partir da mutabilidade das linguagens do homem” (CNBB, 2011, p.36). Segundo o estudo: “De uma comunicação autêntica e eficaz depende, em larga escala, o próprio modelo de Igreja que se almeja e sua capacidade missionária” (Ibidem, p. 42).

\begin{abstract}
A comunicação social se torna processo, conteúdo e rede. É processo, porque foi em espaços de intensas e ricas experiências de relação comunicativa comunitária que Cristo transmitiu sua mensagem e os apóstolos motivaram os cristãos ao ágape fraterno. Revela-se conteúdo porque abarca o comportamento, as tendências e os estilos de vida contemporâneos. Finalmente, converte-se em rede de relações em virtude das novas e originais ocasiões oferecidas pelos meios da comunicação midiática a uma cultura cristãmente inspirada, para que se difunda e entre em diálogo com outras culturas (Ibid., p. 39).
\end{abstract}

Em maio de 2011, durante a $49^{a}$ Assembleia Geral da CNBB, realizada em Aparecida (SP), foi aprovado o documento Diretrizes Gerais da Ação Evangelizadora da Igreja no Brasil (2011-2015), que atualiza as perspectivas, passos e “urgências” da evangelização no País. Entre essas "urgências”, segundo o documento, está a que coloca a Igreja "a serviço da vida plena para todos"41 (CNBB, 2011, n. 106), evangelizando com “novos areópagos” (Ibidem, p. 117), como o mundo universitário, o mundo das instituições governamentais e não-governamentais e o da comunicação:

Tornam-se inadiáveis mais investimentos tecnológicos e qualificação de pessoal, para o uso adequado dos meios de comunicação, uma ousada pastoral da comunicação, garantindo a presença da Igreja no diálogo com a mentalidade e a cultura contemporâneas, à luz dos valores do Evangelho (Ibid., p. 117).

\footnotetext{
${ }^{41}$ As demais são: "Igreja em estado permanente de missão”; “Igreja: casa da iniciação cristã”; “ Igreja, lugar de animação bíblica da vida e da pastoral”; e "Igreja: comunidade de comunidades”.
} 
Ao se debruçar sobre o tema da evangelização, a irmã paulina Vera Ivanise Bombonatto, especialista no tema da Teologia, ressalta que existe um elo entre Igreja e comunicação. "Nada pode romper esta relação, pois ela está fundamentada no fato de que a salvação anunciada por Cristo realiza-se essencialmente como ato de comunicação” (BOMBONATTO, 2009, p.15). Para a pesquisadora, a comunicação é uma dimensão essencial e constitutiva da Igreja, pois “toda a igreja é e faz comunicação” (Ibidem, p. 16), uma atividade que estaria, segundo ela, relacionada à sua própria missão ${ }^{42}$, como parte integrante e essencial da revelação cristã (Ibid., p. 61).

\subsection{Características do jornalismo evangelizador segundo profissionais, representantes de instituições católicas e especialistas}

A despeito da complexidade do conceito de evangelização, Moreira (1994), após examinar o referencial teórico sobre o tema e relacioná-lo à atividade jornalística, conclui que existe evangelização no jornalismo quando:

1) (...) se fomenta a fraternidade, se luta pela justiça, se promove o bem comum, se busca a mudança social (...).

2) o discurso (...) deixa de ser fechado, autoritário e passa a ser participativo, aberto. (...)

3) a própria notícia torna-se (...) capaz de levar à análise e à transformação; quando são apresentados ao ouvinte [especificamente referindo-se às emissoras de rádio] os seus antecedentes e as consequências, como meio de se perceber as repercussões comunitárias ou sociológicas do fato para a formação da consciência moral.

4) (...) inclui o compromisso de privilegiar a defesa e promoção dos direitos humanos e da liberdade, de dar voz aos marginalizados e às minorias, de promover e impulsionar o senso de cidadania, de abrir ao debate todos os temas que signifiquem desenvolvimento humano e cristão.

\footnotetext{
${ }^{42}$ Ver APÊNDICE F, entrevista realizada com Vera Ivanise Bombonatto no dia 2 de novembro de 2012.
} 
5) (...) compreende (...) todo o processo de converter a mentalidade do ouvinte para o Evangelho, destacando os valores humanos, propondo os valores cristãos-evangélicos, chamando o ouvinte a aderir a uma comunidade de fé na qual se evangelize continuamente e se faça evangelizador (MOREIRA, 1994, pp. 33-34).

Para o autor, o ato de evangelizar inclui "a luta pela justiça, a construção da fraternidade, a promoção do bem comum, a busca de mudanças sociais”. Em relação a uma instituição como a Igreja Católica, que tem como missão também educar e transmitir valores segundo sua visão de mundo, o jornalismo “abre a possibilidade de um apostolado”, segundo ele, uma vez que "a leitura dos fatos pode ser feita a partir do seu referencial e segundo sua mensagem" (Ibidem, p. 27).

Entra aí uma discussão ética. Em tese, o jornalista - e o veículo para o qual trabalha deveria colocar-se numa posição neutra e publicar tudo o que merecesse ser notícia, deixando ao público a tarefa de tirar suas próprias conclusões.

Especificamente sobre a pretendida objetividade que o jornalismo deve buscar, muitos estudos já concluíram que ela é um ideal a ser perseguido, mas de difícil alcance, já que "um fato só é um fato em algum universo de discurso” (PARK, 1996, p.178). Para estudiosos como Nilson Lage (1979, pp. 107-111), da Universidade Federal de Santa Catarina, “as nomeações preferenciais, os critérios de seleção de fatos e sua ordenação (...) estão previamente produzidos dentro de um código cultural” e “a imparcialidade e a objetividade são máscaras eventuais que mal ocultam a presença humana, o engajamento e a participação”.

Corazza (2004) defende que "as emissoras católicas são meios de comunicação inseridos no mundo e na sociedade e, por isso, devem estar abertas às necessidades e problemas do homem contemporâneo. Uma dessas necessidades é a da informação” (CORAZZA, 2004, p. 275). Se essas rádios estão no espaço público, precisam, na opinião da autora, informar a população, promovendo um jornalismo cidadão. Nessa perspectiva, a evangelização assume um caráter democrático e participativo e não de discurso proselitista e autoritário, ainda que com posições claras. "E o jornalismo, assim, pode ser um instrumento para alcançar esse fim” (Ibidem). 
Indagado sobre a importância do jornalismo na programação da Rádio Aparecida, seu diretor-geral, o padre César Moreira ${ }^{43}$ afirma que o jornalismo, para a emissora, é uma forma de evangelização. "Para nós, evangelização também se faz via jornalismo, como uma leitura crítica da realidade, formação de opinião, exercício de cidadania, tudo isso diz respeito a jornalismo”, explica (APÊNDICE A).

E o diretor acrescenta, explicitando quais as principais diretrizes que a rádio segue para fazer jornalismo:

O Concílio Vaticano II. Dois documentos básicos: Gaudium et Spes $^{44}$ e Lumen Gentium ${ }^{45}$. Um fala da realidade divina e outro, da realidade humana, ou seja, um olha de cima para baixo e outro olha de baixo para cima. Esses dois documentos formam o cerne da nossa evangelização. Então, nós não estamos chutando. Estamos falando o que o concílio fala, nada mais do que isso.

Em relação aos valores que o jornalismo da rádio busca expressar, acrescenta:

Nosso negócio é a transformação da pessoa humana (...). A linha da Rádio Aparecida é valorizar o humano, defender tudo o que é humano, porque o humano é a forma de chegar ao divino. E o jornalismo passa por isso, valores humanos, colocar o sujeito de pé, brigar as brigas que ele precisa, lutar pelos interesses, pelos direitos que ele tem.

Sobre a principal diferença entre a evangelização praticada pela emissora, em relação à Rádio Canção Nova, o padre César explica: “Nós fazemos uma evangelização que é real, daí a diferença com a Canção Nova. A Canção Nova fica em torno de Deus. Nós fazemos de baixo para cima e não de cima para baixo”. Para o padre César Moreira, a Rádio Aparecida sempre

\footnotetext{
${ }^{43}$ Entrevista concedida à autora no dia 9 de julho de 2011, em São Paulo (ver APÊNDICE A).

${ }^{44}$ Constituição Pastoral Gaudium et Spes (Alegria e Esperança) Sobre A Igreja no Mundo Atual, lançada pelo Papa Paulo VI em dezembro de 1965, durante o Concílio Vaticano II. Disponível em http://www.vatican.va/archive/hist_councils/ii_vatican_council/documents/vat-ii_const_19651207_gaudium-etspes_po.html. Acesso em 15 de novembro de 2012.

${ }^{45}$ Constituição Dogmática Lumen Gentium (A Luz dos Povos), lançada pelo Papa Paulo VI em novembro de 1964, também durante o Concílio Vaticano II. Disponível em http://www.vatican.va/archive/hist_councils/ii_vatican_council/documents/vat-ii_const_19641121_lumengentium_po.html. Acesso em 15 de novembro de 2012.
} 
teve um público crítico, razão pela qual, segundo ele, a própria audiência espera que a rádio assuma posições e as expresse:

\begin{abstract}
A Rádio Aparecida sempre assumiu uma atitude crítica. No começo da rádio, o padre Vitor [Coelho de Almeida, missionário redentorista e um dos fundadores da Rádio Aparecida], lá em mil novecentos e nada, a rádio foi fechada, porque ele falou de direitos humanos, ele leu a Declaração de Direitos Humanos e acharam que a rádio estava ofendendo o governo. Então, nós já temos tradição de fazer a análise da realidade.
\end{abstract}

E essa tradição de "fazer a análise crítica da realidade" se expressa em grande parte no destaque que a rádio dá para os editoriais e comentários, que integram seus radiojornais. "Nós fazemos questão do editorial, porque é uma forma de colocar a opinião da gente (...). Ele [o noticiário opinativo] é que forma a consciência nas pessoas”. Sobre a linha editorial adotada pelo jornalismo da rádio, ele detalha como essa é aplicada e os fatos de interesse que são selecionados para as edições diárias:

Primeiro, as notícias do dia, o que for notícia do dia. Mas nem tudo o que for notícia do dia nos interessa. Por exemplo, violência não nos interessa, exploração nenhuma. Sobretudo a área econômica e política. Depois, notícias que interessam ao maior número de pessoas, sobretudo às do andar de baixo, então a coisa mais popular, direitos das pessoas, cidadania. Notícias do dia, sobretudo política e economia, questões que interessam ao maior número de pessoas, e aquelas teses que a Igreja defende, as questões dos movimentos, a questão da terra, das pastorais, do índio, essas brigas a gente compra. Um pouquinho de internacional, sobretudo destaque para a América Latina. Então, basicamente, é por aí que passa a nossa conversa.

E, sobre a divulgação de notícias sobre a Igreja Católica, ele explica que essas entram no noticiário da rádio quando têm algum "fundo social”:

O que nos interessa é mais de fundo social. O que diz respeito ao religioso geralmente a gente não dá. Em relação à Igreja, o que é de fundo social. Essas notícias de que vai ter missa não sei onde, procissão, a gente não perde tempo com isso. Nada que é paroquial nos diz respeito. Claro que um ou outro programa divulga uma festa religiosa, mas no jornalismo não. $\mathrm{O}$ 
jornalismo é só o que possa mexer com a vida das pessoas. Se não tiver repercussão na vida das pessoas a gente não fala.

O editor-chefe de Jornalismo da Rádio Aparecida, Ederson Santos, também abordou em entrevista $^{46}$ à autora as linhas mestras do “jornalismo evangelizador”, adotadas pela rádio:

(...) nós temos uma linha de evangelização, que é a seguinte: valorizar o ser humano, em busca do divino. Então, na evangelização, a gente não pode limitar a programação no relacionamento meu com Deus, senão a programação seria isso o dia inteiro. (...) Então, é enxergar Deus no próximo. E não tem tabu. O próximo tema que o padre César vai tratar no editorial é o homossexualismo, mas o tema é abordado de maneira plural. A Igreja tem tal pensamento sobre o tema, mas, se você não concorda, pode ligar e dar a sua opinião. E nós lemos todas. Outro dia, nós fizemos um debate sobre a legalização da droga e quem é favorável, lógico, a gente abre espaço. Então, essa é a filosofia nossa. É valorizar o ser humano, em busca do divino. E o que quer dizer isso? Nós entendemos que a evangelização não acontece somente no sermão. Claro que, também no sermão. Mas acontece diariamente. Em busca da cidadania. O nosso maior desafio é fazer com que o povo brasileiro seja cada vez mais cidadão. Porque, se o povo brasileiro fosse cidadão, se participasse mais ativamente da vida política, se todo mundo se preocupasse com isso, a gente teria uma cidade, um estado, um país, um mundo melhor. Então, a nossa filosofia é justamente despertar para o senso de cidadania. E, claro, prestação de serviço, que é obrigação de toda rádio fazer (APÊNDICE B).

Santos explica que os radiojornais da Aparecida seguem o modelo tradicional de editorias do jornalismo dos grandes veículos de comunicação, mas com a “filosofia” da rádio:

As notícias estão sempre de acordo com a nossa filosofia. Então, se nós temos a filosofia de despertar par a cidadania, nós temos que tratar de tudo, tudo que está sendo tratado que é relevante. Então, os principais assuntos de Política, Economia (...). E a gente seleciona, primeiro, com as agências de notícias, como todas as emissoras fazem, lembrando que só temos uma restrição em relação a assuntos que não vão acrescentar muito, como a violência. Porque não resolve. Em jornalismo não adianta tratar só do problema, tem que tratar da problemática. (...) A imprensa, de forma geral, discute o problema. Mas a problemática é muito maior. Se mataram uma pessoa, tem que perguntar o que ocasionou isso, o que levou a isso. Aí, você vê, por exemplo, que a pessoa está envolvida com drogas. Então, tem que discutir o que está por trás. Não adianta ficar massacrando o assunto, a TV tem mania de fazer isso, mostrando as imagens. É a problemática que tem que discutir. Então, o que interessa para nós é a raiz do fato. Tem um fato,

${ }^{46}$ Realizada no dia 4 de agosto de 2011, em Aparecida (ver APÊNDICE B). 
então nós vamos buscar a raiz do problema. Por exemplo, outro dia aconteceu um atropelamento em frente à rádio (...). No jornal a gente vai aprofundar um pouco mais: "Por que aconteceu isso?” As pessoas ficam em geral restritas ao fato, mas por que aconteceu isso? Porque está mal sinalizado, porque os motoristas não respeitam. Então, vamos procurar a causa, se existe uma campanha de orientação para os pedestres, ou para os motoristas, vamos procurar a Polícia Rodoviária Federal, que é responsável pela rodovia, para saber por que não há uma fiscalização ali, por que aquele trevo está aberto, sendo que é perigoso. Então, a gente trabalha dessa maneira. E abordamos os mais diferentes temas.

O editor explica, ainda, como está estruturado o Jornal Brasil Hoje, que a emissora produz para a Rede Católica de Rádio, e como são selecionadas as notícias sobre a Igreja Católica nas edições:

O Jornal Brasil Hoje nós dividimos basicamente em três editorias: Economia, Política e Geral. Tudo o que é Tecnologia, Meio Ambiente, entra aqui. Porque não tem tantas notícias. Tem que ter um bloco para falar só de Economia, porque é muita coisa, outro para falar de Política, e depois a gente engloba as editoriais em um bloco só. Nesse bloco, entram notícias da Igreja. Você vê que não tem preferência. Se a gente tiver que derrubar uma pauta de Economia ou sobre a Igreja, a gente derruba a da Igreja. Notícia da Igreja entra frequentemente, mas não entra necessariamente em todas as edições. (...) Depois, tem o editorial, no final, que é a palavra da Igreja. O editorial não aborda necessariamente um assunto sobre a Igreja, mas o editorial é sempre feito por um padre, o padre Jesus Flores, da Rádio Difusora, de Goiânia, ou o padre César Moreira, da Rádio Aparecida. Em geral, os assuntos são abordados de forma bem isenta. Tem gente que quer que a gente faça sermão na hora do comentário, tudo baseado no Evangelho, mas nós temos uma leitura mais ampla do Evangelho. Porque esses assuntos dos editoriais precisam ser abordados e muitas pessoas reclamam por nós criticarmos o governo: "Ao invés de vocês fazerem isso, vocês deveriam explicar o Evangelho, que Deus vai cobrar, vai castigar os políticos”. Não, não é que Deus vai castigar os políticos. As pessoas é que têm que votar certo da próxima vez, ter discernimento. Tem que se ajudar, senão não vai. Deus deu discernimento para nós e tem gente que não usa (risos).

Para o gerente comercial da emissora, Antonio Celso Pinelli ${ }^{47}$, o diferencial da Rádio Aparecida é a busca por levar “informação e formação" aos ouvintes (APÊNDICE C). Ao longo do Jornal Brasil Hoje, é possível acompanhar slogans que refletem essa orientação: "Rede Católica de Rádio. A união das emissoras comprometidas com a busca de uma

\footnotetext{
${ }^{47}$ Entrevista realizada em 4 de agosto de 2011, em Aparecida (ver APÊNDICE C).
} 
sociedade mais justa e fraterna"; "RCR Sat. Emissoras da Igreja unidas para transformar pela formação e informação"; e "RCR Sat. Compromisso com a verdade e com a informação mais rápida e segura”.

Já no caso da Rádio Canção Nova, as notícias sobre a Igreja Católica são sempre pautadas no Jornal Canção Nova $1^{a}$ e $2^{a}$ Edições, e aparecem no início dos dois radiojornais

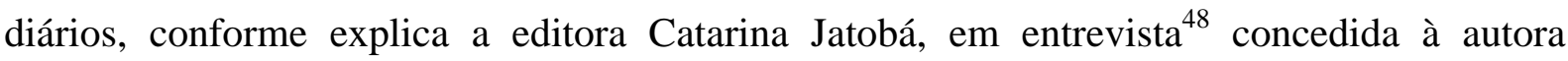
(APÊNDICE D):

(...) nós queremos ser a voz da Igreja nos meios de comunicação. Se a gente não falar da Igreja, quem vai falar? Muitas vezes, as pessoas sabem o que está acontecendo na Inglaterra, em Londres, mas não sabem o que está acontecendo na própria paróquia, que o pessoal está arrecadando roupas para doar em benefício de alguém e a pessoa não vai ajudar por desconhecer.

A editora explicita quais são os objetivos da rádio em fazer jornalismo:

O objetivo do nosso jornalismo é deixar o nosso ouvinte informado, porque a gente sabe que tem pessoas que ouvem a Canção Nova o tempo inteiro. Então, a gente não quer que a pessoa fique bitolada, porque hoje a gente sabe que uma das nossas maiores necessidades é a comunicação. A gente precisa estar informada, saber o que se passa no mundo, não ser um cristão alienado, porque essa não é a nossa proposta: de que as pessoas fiquem ali rezando o tempo inteiro, sem saber da necessidade de quem está do lado. Então, é informar, conscientizar, sempre primando também pelo nosso perfil editorial, que é "um jornalismo a serviço da vida e da esperança”.

E como está estruturado o radiojornal em termos de editorias:

Política, Economia, Igreja, Saúde, Meios de Transporte, quando tem, Aviação, Tecnologia. Tudo isso para a gente formar o cidadão por completo, para deixar o nosso ouvinte informado de todas as coisas, de todas as áreas. A gente procura sempre dar mais essa visão aberta, de que as pessoas precisam se informar: "A taxa básica de juros da Selic subiu para 12,75\%". A gente procura explicar um pouco o que isso interfere na vida da pessoa. Um enfoque de Economia seria assim: "O Índice de Preços ao Consumidor está em tantos por cento...” O que isso vai afetar no seu bolso no fim do mês? Como vão ficar as suas contas, a cesta básica. Então, dar essa visão,

${ }^{48}$ No dia 10 de agosto de 2011, em Cachoeira Paulista. 
digamos assim, mais clara. Agora, a crise financeira que está acontecendo nos Estados Unidos. A gente procura explicar para que a pessoa fique por dentro de tudo, de todos os assuntos.

Com relação à postura da Canção Nova de evangelizar pelos meios de comunicação e também pelo jornalismo, ela comenta:

(...) evangelizar é justamente você permear a notícia pelo Evangelho. Você coloca a essência do Evangelho naquilo que você fala, naquilo que você transmite. Daí vem o nosso perfil, a nossa maneira de fazer, com respeito pelo outro, a gente evita falar de escândalo, de violência. Quando é uma coisa que é realmente necessária a gente vai apurar os fatos, para primar pela pessoa, pela dignidade da pessoa. Evangelizar no sentido também de apresentar ao nosso público, ao nosso ouvinte, aquilo que ele pode fazer de bom também. Por exemplo, no início do inverno, a gente fez a campanha do agasalho: fizemos uma matéria sobre doação de agasalhos, doação de sangue, coisas de interesse público para despertar nas pessoas a sensibilidade e a necessidade do próximo, Então, é dessa forma que eu vejo que a gente pode evangelizar através do nosso jornalismo, com esse nosso diferencial, que é "a serviço da vida e da esperança”.

E, justamente, entre os slogans ou chamadas que a emissora adota e que podem ser ouvidos ao longo das edições diárias do Jornal Canção Nova $2^{a}$ Edição, essa mensagem se repete: "Rede Canção Nova de Rádio: a serviço da vida e da esperança” e "Rede Canção Nova de Rádio, nós espalhamos o amor pelo ar”.

O apresentador do Jornal Canção Nova $2^{a}$ Edição, Reinaldo César, explica ${ }^{49}$ o que entende por estar “a serviço da vida e da esperança”, o slogan da Canção Nova:

Estar a serviço da vida e da esperança é olhar para as pessoas, é olhar para a comunidade. Eu vejo que o slogan "a serviço da vida e da esperança”, ele cai muito bem na Canção Nova e também ele é uma referência da CNBB, a Conferência Nacional dos Bispos do Brasil, porque, quando se faz um jornalismo ético, pautado na qualidade, na preocupação com as pessoas, com o ser humano, com seus valores fundamentais, ou seja, quando nós carregamos esses valores que nós temos e mantemos esses valores, nós estamos pautando pela vida e esperança. A essência do jornalismo também não foge disso. Um jornalismo ético vai trabalhar em favor da sociedade, da comunidade. Ele vai informar, levar informação, denunciar, se preciso for, e ajudar nas mudanças, nas transformações que a sociedade vai criando no seu dia a dia. Os meios de comunicação hoje têm uma função social muito

\footnotetext{
${ }^{49}$ Em entrevista realizada no dia 10 de agosto de 2011, em Cachoeira Paulista (ver APÊNDICE E).
} 
importante. Pena que muitos deles banalizaram muito as coisas importantes na vida das pessoas. Eu acho que a Canção Nova está no caminho correto (...) dentro dessa proposta, ou seja, que é levar vida, que é levar esperança, que é anunciar à sociedade a boa nova, e qual é a boa nova? Levar vida e esperança para as pessoas à luz do Evangelho (APÊNDICE E).

À indagação sobre como fazer isso por meio do jornalismo, o apresentador da Canção Nova respondeu:

Eu vejo que é necessário cada vez mais qualificar as pessoas. Formação: essa é a palavra-chave. Formação das pessoas, sendo ou não jornalistas, para levar alegria, para levar esperança, para levar vida, para edificar as pessoas. A sociedade hoje é ansiosa. Eu não sei se ela está tão bem informada assim, com os meios de comunicação de que dispomos atualmente, com o advento da internet. Então, eu vejo que é preciso avançar na formação das pessoas. Cuidar dos valores fundamentais, que estão sendo deturpados, revertidos, por muitos meios de comunicação. E a gente precisa ter esse cuidado, esse olhar diferenciado, para não fugir daquilo que nós propomos, que é trabalhar a serviço da vida e da esperança, fazendo um jornalismo ético, (...) pautado na decência, sem sensacionalismo barato e fazer um jornalismo de fato voltado para a sociedade, informando, formando, levando alegria e levando a boa nova. E lutando também por justiça, porque o jornalismo da Canção Nova, quando fala de vida e esperança, ele quer ver também esse caminho de paz, esse caminho de justiça. Como dizia João Paulo II, sem justiça não há paz. Então, se não há justiça, a paz fica comprometida. E nós precisamos muito trabalhar pela paz a partir de nossas atitudes, nossas ações e o nosso ser. O nosso comportamento também evangeliza.

A pesquisadora paulina Vera Ivanise Bombonatto ${ }^{50}$ discorre sobre o que ela considera um jornalismo evangelizador e uma maneira “cristã” de fazer jornalismo:

Uma maneira cristã de fazer jornalismo seria colocar em prática os ensinamentos de Jesus. Por exemplo, a partir de qual perspectiva você se coloca para dar uma notícia? Você pode dar uma notícia a partir da perspectiva de acusar, de denunciar as autoridades porque não cuidaram de determinadas coisas. Você pode dar uma notícia a partir da perspectiva do desrespeito à vida humana. Então, a perspectiva cristã, a perspectiva do ensinamento de Jesus, porque esse é o diferencial, o modo é a partir da defesa da dignidade humana. Então, você dá a notícia mostrando o quanto aquela notícia foi contra a dignidade da pessoa, se se respeitou a pessoa, se se respeitou a vida, essa é a perspectiva cristã, o respeito à vida, ao valor da vida, fazer uma leitura esclarecedora, conscientizadora sobre esses valores e

\footnotetext{
${ }^{50}$ Em entrevista concedida à autora no dia 2 de novembro de 2012, em São Paulo (ver APÊNDICE F).
} 
não o mero espetáculo, o jornalismo barato, o sensacionalismo e a apelação (APÊNDICE F).

A fim de esclarecer melhor o que seria um jornalismo evangelizador, a especialista diz acreditar que esse não deve ter por objetivo converter as pessoas para uma determinada causa, mas antes “colocar-se ao lado da pessoa humana e dos necessitados”, na perspectiva do Gaudium et Spes:

\begin{abstract}
A partir do Concílio Vaticano II, o Gaudium et Spes, que fala que todas as alegrias, as tristezas e as dores da humanidade são as alegrias, as dores e as tristezas da Igreja e dos seguidores de Jesus. Então, conforme o caminhar dos tempos, a Igreja tem que ir acertando o passo, caminhando com os tempos, não pode ficar atrasada.
\end{abstract}

Sobre a questão da abordagem de temas que poderiam ser considerados "tabus” para uma pauta do jornalismo católico, como aborto, pesquisa com células-tronco, homossexualismo, assim como escândalos envolvendo a Igreja, a pesquisadora afirma que "nada é tabu para o cristão", mas que o jornalismo deve falar “cristãmente” de todas as coisas. "Nada é tabu, porque é humano e nada que é humano é desprezível. E nada deve ser tabu para o cristão, mas tudo tem que ser abordado a partir da ótica cristã, de promoção de valores da vida”, afirma.

Falando de um ponto de vista pessoal, o presidente da Rede Católica de Rádio, frei João Carlos Romanini $^{51}$, explica como vê especificamente essa questão:

Não estou falando como instituição, mas como jornalista. Eu acho que a informação tem que ser discutida. As pessoas que trabalham comigo sabem disso. Eu sou extremamente socializador de informações. Nós, enquanto meios de comunicação da Igreja, nós temos que fazer o quê? Socializar a nossa posição. Então, acredito que todos os tabus têm que ser discutidos. (...) a verdade, ela tem vários lados. Logicamente, que não vai ser assim, o meu meio de comunicação que vai falar: a Igreja é contra o uso de camisinha. Vai ser o papa, vai ser o bispo que vai dizer isso dentro do meu meio de comunicação. Como vai ter o ativista que vai dizer que nós estamos

\footnotetext{
${ }^{51}$ Em entrevista concedida à autora no dia 22 de fevereiro de 2013, em São Paulo (ver APÊNDICE G).
} 
errados. Tudo bem. Logicamente que, ao fazer jornalismo, aí entra nos vários níveis de concepção que as pessoas têm do jornalismo, do fenômeno comunicacional. Nós temos vários tipos de entendimento do cristão. Mas eu sou um grande defensor da verdade e acho que tudo deve ser abordado. (...) os meios de comunicação não têm a verdade absoluta. Eu vou colocar A, B, C e D e você resolve o seu problema. Então, as informações estão aí para você tomar a decisão. O meu meio nunca vai tomar a decisão. O jornalismo leigo que está aí não modifica do nosso. Porém, nós temos que entender que determinados meios não vão abordar determinados assuntos. Por exemplo, o casamento gay. Nós estamos dentro de uma sociedade em que as pessoas estão discutindo isso. Consequentemente, a gente vai discutir isso. Só que a gente tem que discutir isso com técnicos, com pessoas que entendem do assunto, com sociólogos, com políticos. Porque nós estamos vivendo numa sociedade cada vez mais diversa e complexa. (...) o respeito às diferenças tem que existir. Só não vamos fazer apologia, nem perseguição. Porém, pode ter dentro da própria estrutura da Igreja movimentos, meios até homofóbicos, mas não são a Igreja, são pessoas que se dizem católicas, ou cristãs, que defendem isso. Então, as contradições que nós temos são as contradições do mundo. E nós não somos diferentes (APÊNDICE G).

O tema do jornalismo produzido no contexto de uma instituição religiosa e sua provável perda de isenção e objetividade, cânones norteadores e princípios básicos da atividade, foi abordado com o presidente da Comissão Episcopal Pastoral para a Comunicação da Conferência Nacional dos Bispos do Brasil (CNBB), dom Dimas Lara Barbosa 52 . "Não existe jornalismo neutro”, diz ele. "Infelizmente, essa é uma grande verdade. Cada jornal tem a sua ideologia” (APÊNDICE H).

Dom Dimas também falou sobre a questão do jornalismo “católico” ou “evangelizador”, assim como os temas e linha editorial que esse deve adotar, na sua opinião:

(...) tomando os grandes jornais, como o Jornal Nacional. Por exemplo, não é qualquer matéria que você consegue introduzir lá, mesmo que você tenha amigos dentro da Rede Globo, etc. porque existe uma linha editorial, que vai dar ênfase a determinados tipos de temas, e outros vão deixar despercebidos. Por exemplo, os movimentos sociais: quais são os grandes jornais que efetivamente tomam posição em defesa dos movimentos sociais? Normalmente, é de demonização dos movimentos sociais, independente da matriz ideológica do movimento social.

(...) falando especificamente do jornalismo católico. É possível você evangelizar através do jornalismo? Sem dúvida alguma. Tudo que você faz com base na ética, na verdade, no diálogo, dando visibilidade às lutas sociais

\footnotetext{
${ }^{52}$ Em entrevista realizada no dia 9 de fevereiro de 2013, em São Paulo (Ver APÊNDICE H).
} 
do povo, denunciando, promovendo os direitos humanos, isso é evangelização. A evangelização não é só quando você faz um anúncio formal da pessoa e da obra de Jesus Cristo, mas quando você promove os valores do Evangelho. Então, um âncora, ele pode perfeitamente ser um arauto da ética, de valores que são profundamente humanos, sem mencionar em nenhum momento um documento da Igreja (...) Naturalmente, o jornal vai ter também a sua linha editorial. Ele vai assumir determinados temas, que podem até ser temas comuns da grande mídia. Eu acho que o jornal de uma rádio ou da imprensa católica também participa, comenta, escreve, opina sobre os mais diversos temas (APÊNDICE H).

Em relação ao questionamento sobre como fica a abordagem, por parte dos veículos católicos, de temas considerados tabus ou de escândalos envolvendo a Igreja, o arcebispo diz:

Qualquer instituição que esteja envolvida em um escândalo, numa agressão midiática - quando eu falo "agressão midiática" entenda o consenso dos meios em relação a sua própria posição -, ela vai buscar assessoria sobre como se posicionar de tal maneira que ela não fira as regras da ética e, ao mesmo tempo, não se omita.

(...) eu não acho, pelo contrário, que a Igreja deva se omitir diante de temas delicados. Ela deve, inclusive, dar a cara a tapa, mesmo que tenha que apanhar e ser muito criticada pela sua própria defesa da vida ou de outros princípios em que acredita.

(...) o jornal [católico] deve abordar temas polêmicos? Deve. Mas, se ele quer ser fiel à Igreja, ele tem que ter estrutura para não manipular os dados, não se omitir, dizer claramente qual é o pensamento, mas dando as razões pelo que faz.

José Marques de Melo, diretor titular da Cátedra Unesco/Metodista de Comunicação e professor emérito do Departamento de Jornalismo da Escola de Comunicações e Artes da Universidade de São Paulo, uma das maiores autoridades do País no tema da comunicação eclesial e sobre a imprensa católica no Brasil, também abordou ${ }^{53}$ a questão do jornalismo praticado em uma emissora religiosa.

Indagado sobre a questão de como obedecer aos princípios e cânones do jornalismo, como objetividade, veracidade, isenção, multiplicidade de fontes, dentro de uma instituição, como é o caso das emissoras católicas, o professor respondeu: “O que não pode é confundir

\footnotetext{
${ }^{53}$ Em entrevista realizada no dia 12 de março de 2013 (Ver APÊNDICE I).
} 
jornalismo com propaganda, jornalismo com proselitismo, mas você pode evangelizar dando a boa informação” (APÊNDICE I).

É um problema de agenda, uma questão de pauta. Porque, (...) não existe jornalismo neutro. Todo jornalismo tem, na verdade, um parti pris, que é a posição editorial da empresa. Mas, quando o jornalismo é sério, a linha editorial, não significa que ela inibe a questão da veracidade, da objetividade da informação. Então, é possível fazer bom jornalismo dando só boas notícias, notícias positivas, evitando o sensacionalismo barato. Mas também não dá para ser um jornalismo sempre "cor de rosa”. Eu dizia para os meus alunos que estudaram na USP, na Metodista, na Cásper Líbero, que o mundo não é tão cor de rosa assim. É preciso introduzir também algumas variáveis do cotidiano que deem às pessoas uma ideia da realidade tal qual ela é.

Para o professor, a forma com que temas de interesse da Igreja Católica devem ser abordados depende da audiência: “(...) Se você tem uma rádio como a Aparecida, que é uma rádio de massa, que transmite para o Brasil inteiro, tem que levar em consideração o cidadão médio. Se você tem uma rádio de elite, então você pode trabalhar algumas formas mais sofisticadas de informação. Varia de veículo para veículo e de público para público”.

E, com relação à inclusão de temas considerados tabus ou que sejam delicados para a Igreja e como abordá-los, o professor se posicionou da seguinte forma:

Eu acho que os temas tabus têm que ser tratados porque, se você não tratar dos temas tabus na sua emissora, os outros vão tratar e podem tratar de maneira distorcida. O que não pode haver é sensacionalismo no sentido de exacerbação dos ânimos. Eu acho que as emissoras religiosas têm um papel, que é um papel, sobretudo, de acalmar a população. 


\subsection{A responsabilidade social do jornalismo}

Discorrer sobre as funções e papéis que o jornalismo desempenha em nossa sociedade remete necessariamente a diversos autores que se dedicaram ao estudo dessa atividade. Em sua obra clássica Iniciação à Filosofia do Jornalismo, cuja primeira edição foi lançada em 1960, Luiz Beltrão, pioneiro da pesquisa científica sobre os fenômenos comunicacionais no Brasil, lança luzes sobre o papel e a natureza do jornalismo, dando ênfase à ética e à responsabilidade social intrínsecas em sua prática. Segundo a definição do autor, jornalismo é “a informação de fatos correntes, devidamente interpretados e transmitidos periodicamente à sociedade, com o objetivo de difundir conhecimentos e orientar a opinião pública, para promover o bem comum” (BELTRÃO, 2003, p.67).

Ao refletir sobre o jornalismo como instrumento de cidadania, o jornalista e professor Enio Moraes Júnior (2005) conclui que o jornalismo tem servido como um dos alicerces para a consolidação dos direitos humanos, da democracia e da cidadania, e defende que "a função da imprensa é agendar as discussões de relevância social e de interesse público” (MORAES JÚNIOR, 2005, pp. 32-35).

Cabe a ela [imprensa] informar, mediar, transmitir a informação para que os acontecimentos sejam captados pelo público da notícia, o homem comum. Uma imprensa ética e socialmente responsável é aquela que age em nome do bem comum, respeitando e resguardando os direitos humanos e a democracia. Filiando-se intencionalmente, portanto, à cidadania (Ibidem).

De acordo com o pesquisador, visto sob o ângulo da cidadania, jornalismo pode ser conceituado como:

(...) o agendamento de temas socialmente relevantes em que o trabalho do emissor está pautado intencionalmente da difusão da noticia "correta e plena” (Chaparro, 1994) capaz de conduzir o receptor a uma ação (Arendt, 1987) em nome da conquista e da preservação dos seus direitos civis, políticos e sociais (Marshall, 1967) (Ibidem, p. 39).

Para Victor Gentilli (1995), professor da Universidade Federal do Espírito Santo (Ufes), que analisou em sua dissertação de mestrado a difusão da informação como um direito de 
cidadania, o jornalismo pode vir a ser um instrumento para a "ampliação da cidadania no Brasil”, uma vez que o País consolidou direitos políticos plenos e amplos, mas ainda enfrenta dificuldades para a consolidação dos direitos sociais (GENTILLI, 1995, p.14).

O autor argumenta que o jornalismo, como um "processo de reconstrução da realidade concreta”, é fundamental e indispensável para a vida do homem moderno "para que ele se localize no mundo (...), situe-se diante do conjunto de circunstâncias que o cerca, organize sua vida a partir do conhecimento (...), tome suas decisões e faça suas escolhas a respeito dos assuntos que lhe interessem” (Ibidem, p.199).

Para que cada homem possa participar das decisões que lhe interessem e/ou lhe digam respeito em condições de igualdade, é indispensável um sistema de comunicações que ofereça ao conjunto de cidadãos as informações básicas e as alternativas possíveis para que tais decisões sejam tomadas, conscientemente - na medida do possível -, com a possibilidade máxima de acesso à informação (Ibid., p. 200).

Alzira Alves Abreu (2003), pesquisadora da Fundação Getúlio Vargas do Rio de Janeiro, discute em artigo ${ }^{54}$ as relações que se estabelecem entre imprensa e cidadania no País. Para a autora, uma das peculiaridades do processo de democratização do Brasil, após o fim do regime militar, foi a ampliação do papel da mídia, que se tornou uma das mais importantes instituições coparticipantes na construção de nossa cidadania. A autora argumenta que "a informação é um dos elementos fundamentais para que o indivíduo possa exercer plenamente seus direitos” (ABREU, 2003, p.26).

O português Nelson Traquina (2004), da Universidade Nova, de Lisboa, um dos principais teóricos dedicados ao estudo do jornalismo na atualidade, defende que é a informação jornalística que, historicamente, tem sido uma das principais vias pelas quais o homem "conhece os fatos e opiniões" que o rodeiam e que permitem a ele compreender a realidade. Dessa forma, o jornalismo desempenha o papel de "fornecer aos cidadãos as informações necessárias para o desempenho das suas responsabilidades cívicas, tornando

${ }^{54}$ Disponível em http://bibliotecadigital.fgv.br/ojs/indez.php/reh/article/view/2185/1324. Acesso em 20 de janeiro de 2012. 
central o conceito de serviço público como parte da identidade jornalística” (TRAQUINA, 2004, p.50).

Os jornalistas Bill Kovach e Tom Rosenstiel (2004), em estudo sobre a cultura do jornalismo nos Estados Unidos, Os Elementos do Jornalismo: o que os jornalistas devem saber e o público exigir, defendem que a principal função do profissional da imprensa é “fornecer aos cidadãos as informações de que necessitam para serem livres e se autogovernar" (KOVACH; ROSENSTIEL, 2004, p. 31).

\begin{abstract}
A imprensa nos ajuda a definir nossas comunidades, nos ajuda a criar uma linguagem e conhecimentos comuns com base na realidade. O jornalismo também ajuda a identificar os objetivos da comunidade, seus heróis e vilões. (...) A imprensa funciona como um guardião, tira as pessoas da letargia e oferece uma voz aos esquecidos (Ibidem).
\end{abstract}

Tal é a relevância da informação para a vida em sociedade que, desde meados do século passado, ela é considerada um direito, garantido na Declaração Universal dos Direitos Humanos da Organização das Nações Unidas (ONU), aprovado em 10 de dezembro de 1948. A declaração preconiza, em seu artigo XIX, que

toda pessoa tem direito à liberdade de opinião e expressão; este direito inclui a liberdade de, sem interferência, ter opiniões e de procurar, receber e transmitir informações e ideias por quaisquer meios e independentemente de fronteiras ${ }^{55}$.

Mais que um direito do cidadão, Beltrão defende que o jornalismo passou a ser uma "necessidade social (...) à proporção que vão se ampliando e diversificando as coletividades, que crescem as populações, que se incrementa a mobilidade social, que se fortalece o poder político” (2006, p.14).

\footnotetext{
${ }^{55}$ Disponível em http://portal.mj.gov.br/sedh/ct/legis_intern/ddh_bib_inter_universal.htm. Acesso em 10 de janeiro de 2012.
} 
Cicilia Peruzzo, professora da Universidade Metodista de São Paulo (Umesp), em artigo que trata da difusão da informação na sociedade contemporânea, afirma que ética e liberdade de informação são essenciais à sociedade democrática. "Essas dizem respeito ao direito de expressão e ao direito social à informação" (PERUZZO, 2002, p.72).

A autora lembra que, antes de ser empresa privada, destinada a gerar lucro para seus proprietários, ou de atuar como órgão público a serviço de governos (no caso de veículos estatais), o meio de comunicação social - como é o caso de jornais, rádios e emissoras de televisão - é um bem público, cuja utilização deve estar a serviço da coletividade.

O produto do meio de comunicação não é como um sapato de uso externo, descartável quando incomoda o usuário. Ele tem o potencial de interferir nos valores e na formação da cultura, principalmente das crianças e adolescentes (Ibidem, p. 74).

A pesquisadora argumenta que, no caso do Brasil, a exploração comercial da televisão e do rádio por concessão do governo federal contribui para reforçar o fato de que as empresas de comunicação devem respeitar o caráter social da mídia enquanto bem público, de uso normatizado por princípios constitucionais, que determinam que a produção e a programação de emissoras de rádio e televisão atendam, preferencialmente, a finalidades educativas, artísticas, culturais e informativas (Ibid., p. 75).

(...) mesmo os veículos de comunicação que não dependem da concessão de canal pelo governo - o jornal, por exemplo -, ao desempenharem funções no campo da circulação de mensagens no espaço público estarão revestidos do caráter social dos meios, na responsabilidade de exercer a liberdade de expressão e suprir o direito social à informação. A informação é um bem público e social por definição da Unesco (Ibid.).

Para Peruzzo, portanto, “a ética nos meios de comunicação, em sua essência, está organicamente ligada à questão das liberdades informativas na perspectiva do exercício da responsabilidade social da informação” (Ibid.). 


\section{As Emissoras e seus Radiojornais}

Ao se analisarem os históricos das rádios Aparecida e Canção Nova, evidenciam-se duas correntes distintas dentro Igreja Católica, que apesar de terem, em tese, um objetivo comum o de evangelizar pelos meios de comunicação -, provêm de diferentes propostas de atuação. A Rádio Aparecida, de linha redentorista, segue o caminho da Congregação do Santíssimo Redentor, conhecida como Congregação dos Redentoristas, fundada por Santo Afonso Maria de Ligório, em 1732, na Itália. Descendente de uma família nobre e pertencente ao clero napolitano, Ligório, como sacerdote, fez uma opção radical pelos pobres e abandonados dos arredores de Nápoles, segundo relata Gilberto Paiva no livro Rádio Aparecida, 50 Anos de História, lançado em 2001 pela Editora Santuário.

Segundo o autor, a congregação iniciou-se como uma resposta às necessidades materiais e espirituais do povo pobre que vivia na zona rural, nas montanhas fora da cidade de Nápoles, ao mesmo tempo em que, por meio da pregação, procurava suprir as lacunas de formação desses grupos menos favorecidos (PAIVA, 2001, p.16).

A proposta original era é o de levar a "Boa Nova” ou “Boa Notícia”, ou seja, a Palavra de Deus aos fiéis, o que, intrinsecamente já ensejava uma dinâmica comunicacional. Essa, entretanto, é a linha de outras ordens católicas, que fazem referência à missão dos cristãos professada no Evangelho Segundo São Marcos: “... E disse-lhes [Jesus]: Ide por todo o mundo, e pregai o Evangelho a toda criatura...” (Marcos 16,15-18). Segundo o site http://redentoristaspoa.com.br, hoje presentes em 77 países, os redentoristas somam aproximadamente 5,5 mil sacerdotes e seminaristas que professaram os votos de pobreza, castidade e obediência.

A congregação tem um lema tirado do versículo 7 do Salmo 130: Copiosa apud eum redemptio (Nele é copiosa a Redenção). Essa parte do salmo é uma declaração resumida do espírito que motiva os Redentoristas, porque nele Deus se mostra como absolutamente generoso em amor, compaixão e perdão para com a humanidade, amando de tal modo o mundo que deu seu Filho único, Jesus Cristo (Jo 3,16). Os Redentoristas foram tocados por esse 
amor e por isso procuram levar essa Boa Nova ao mundo, mas com especial preferência por aqueles que vivem à margem da Igreja e da sociedade ${ }^{56}$.

Destacado pregador, Santo Afonso escreveu cerca de 100 livros, traduzidos em mais de 70 línguas. Os redentoristas tradicionalmente utilizaram-se dos meios de comunicação social para pregar a palavra de Deus, valendo-se de jornais, revistas, editoras, emissoras de rádio e TV e da internet. Tendo-se expandido para a Europa Central e do Leste, a congregação chegou à América do Norte e América Latina no final do século 19. No Brasil, a vinda dos primeiros missionários da congregação se deu em 1893, em Mariana, Minas Gerais, tendo sido instalado um grupo em Aparecida, com o objetivo de trabalhar no Santuário de Nossa Senhora Aparecida, e em outro em Campininhas, Goiás, vila que daria origem mais tarde à futura capital do Estado, Goiânia.

Poucos anos após instalarem-se em Aparecida, em 1900, os redentoristas criaram uma oficina gráfica para editar o jornal O Santuário de Aparecida, veículo que permanece até hoje, mantendo conteúdo pastoral, com o objetivo de divulgar o culto mariano ${ }^{57}$. A tipografia daria origem à futura Editora Santuário.

Na linha seguida pela Rádio Canção Nova, bem como em todo o complexo comunicacional homônimo, a mensagem emerge de uma corrente mais recente dentro da Igreja Católica, a da Renovação Carismática, surgida na esteira do Concílio Vaticano II, em que o modelo pastoral da Igreja na comunicação com os fiéis foi profundamente modificado. A Renovação Carismática apareceu no momento em que se começava a procurar caminhos para pôr em prática a renovação da Igreja Católica proposta pelo Concílio Vaticano II.

Levar a "Boa Nova” aos fiéis, missão apregoada no Evangelho, ganharia novos paradigmas após o concílio, especialmente na forma de expressão da Igreja Católica, desde as missas até o uso dos meios de comunicação. Entre outras inovações surgidas na esteira do

\footnotetext{
${ }^{56}$ Disponível em http://redentoristaspoa.com.br/pv2/?page_id=2. Acesso em 15 de maio de 2013.

${ }^{57}$ Disponível em http://jornalsanturaio.wordpress.com/16-2. Consultado em 10 de maio de 2013. Segundo a pesquisadora Aline Roes Dalmolin (2012), em tese de doutorado defendida na Universidade do Vale dos Sinos (RS), o jornal é um autêntico representante dos veículos lançados pela Igreja Católica no início do século 20, como reação à formalização da separação entre Igreja e Estado trazida pela primeira constituição republicana. Por meio de uma imprensa de opinião, a Igreja buscava manter sua influência na sociedade e combater os jornais liberais anticlericais em evidência no período.
} 
concílio está o fato de que a missa em Latim caía em desuso e o sacerdote, não mais de costas para os participantes, passava a postar-se de frente para os fiéis, celebrando os ritos no idioma local e em linguagem mais acessível. Na homilia, por exemplo, muitos sacerdotes passaram a usar exemplos cotidianos para ilustrar sua mensagem ao público.

Considerada de linha pentecostal ${ }^{58}$, a Renovação Carismática Católica, ou o Pentecostalismo Católico, como foi inicialmente conhecido o movimento, teve origem com um retiro espiritual realizado em fevereiro de 1967, na Universidade de Duquesne (Pittsburgh, Pensilvânia, EUA). Mas, embora os americanos estivessem presentes no acontecimento apontado como origem do movimento, a Renovação Carismática "explodiu quase ao mesmo tempo em todos os cantos da terra e em todas as igrejas cristãs, sem que se saiba muito bem como é que o fogo se ateou"

Os grupos de oração são a base da estrutura do movimento. Organizados geralmente nas paróquias e liderados por leigos, eles são formados por um número variado de pessoas, em reuniões que acontecem semanalmente. Segundo estimativas do site www.rccbrasil.org.br, essa "tropa de choque” da Renovação Carismática representava, em 2000, quase 13,4 milhões de pessoas em todo o mundo.

No Brasil, a Renovação Carismática disseminou-se rapidamente, coincidindo também com o surgimento da Campanha da Fraternidade, uma ação exclusivamente brasileira, onde os fiéis são convocados a expressarem sua opinião e a construírem colaborativamente, uma mensagem que a Igreja do Brasil vai proferir no ano seguinte. O caminho de volta dessa proposta dos fiéis retroalimentaria as atividades em torno da fé, em todos os âmbitos da Igreja. A Campanha da Fraternidade foi criada em 1964, mesmo ano do Golpe Militar.

O padre jesuíta americano Haroldo Joseph Rahm, que se mudou para o Brasil no mesmo ano, fundando a Comunidade Terapêutica Fazenda do Senhor Jesus para tratar dependentes de álcool outras drogas, é considerado um dos responsáveis por divulgar a Renovação Carismática para muitos dos que viriam a tornar-se suas lideranças. A adesão do padre

\footnotetext{
${ }^{58}$ Em referência ao movimento dentro do cristianismo que coloca ênfase em uma experiência direta e pessoal de Deus por meio do batismo no Espírito Santo.

${ }^{59}$ Disponível em http://www.rccbrasil.org.br/institucional/historico-da-rcc.html. Acesso em 15 de maio de 2013.
} 
salesiano Jonas Abib, fundador da Comunidade Canção Nova, logo no início, deu um grande impulso ao movimento.

O fundador da Canção Nova assim relata como conheceu a Renovação Carismática, por meio do padre Haroldo, durante um período em que passava por dificuldades em seu ministério, em Lorena, São Paulo:

Padre Haroldo veio no dia 2 de novembro de 1971. Falou-nos a respeito do que Deus estava fazendo no mundo por meio da Renovação Carismática Católica. Explicou-nos sobre a Efusão do Espírito Santo; o que eram os dons do Espírito Santo (...). Realmente não entendi bem o que era a Renovação Carismática Católica; também não entendi o que era Efusão do Espírito nem mesmo os Dons. Porém, desejei do fundo do coração. Entendi que era o que me faltava! Houve uma missa. No final, Padre Haroldo, ainda na sacristia, disse a nós, padres, que, se quiséssemos, ele iria impor as mãos sobre cada um, pedindo a Efusão do Espírito Santo. Ficamos sem jeito; mas pior seria dizer que não ... aceitamos! (...). O que aconteceu com os outros eu não sei; sei o que aconteceu comigo. (...) naquela noite, comecei a orar como nunca tinha orado antes. Nem era ainda a oração em línguas; o que acontecia era que a oração vinha de dentro. (...) Eu não saberia explicar. O que sabia é que antes me faltava alguma coisa, que eu pensava ser a fé; porém, o que faltava agora não faltava mais. $\mathrm{O}$ vazio que existia estava inteiramente preenchido. (...) um mês e meio depois, já no começo de 1972, fui a Campinas, em São Paulo, com dez jovens (...). Tivemos a oportunidade de fazer uma "Experiência de Oração" com Padre Harold (...). Lá comecei a entender o que era a Renovação Carismática Católica, a Efusão do Espírito Santo e seus Dons. Melhor ainda: entendi o que tinha acontecido comigo. Naquele mesmo ano estávamos começando as Experiências de Oração no Espírito Santo, em Lorena (ABIB, 2000, pp.16-17)

A dimensão simbólica, icônica, espiritual e festiva, aliada à relevância assumida pelos leigos no campo da espiritualidade, são apontadas pelo teólogo João Batista Libânio (2012), professor emérito da Faculdade Jesuíta de Filosofia e Teologia de Belo Horizonte, como fatores de impacto do movimento, cujo reconhecimento pelo Vaticano se deu em 1993. 


\subsection{Rádio Aparecida: tradição em jornalismo}

A Rádio Aparecida, que completa 62 anos de atividades em 2013, teve sua primeira transmissão no dia 8 de setembro de 1951. Os responsáveis pela conquista da concessão foram os missionários da Congregação do Santíssimo Redentor, entre eles, os padres Daniel Marti e Vítor Coelho de Almeida, primeiros locutores e grandes propagadores da Rádio Aparecida, bem como seu primeiro diretor, o padre Humberto Pieroni. Mas o sonho de ter uma rádio para o Santuário de Nossa Senhora Aparecida começou bem antes, conforme relatado no livro Rádio Aparecida, 50 Anos de História, de Gilberto Paiva (2001).

Em 1935, as rádios Difusora e Record realizaram uma transmissão diretamente do Santuário Nacional, o que despertou grande interesse dos fiéis e ouvintes em geral. A partir daí, começaram os esforços para se obter uma concessão para o santuário. Em 1938, o padre Oscar Chagas, vigário da paróquia de Aparecida, conseguiu um canal exclusivo para ser instalado na cidade, por concessão do governo do presidente Getúlio Vargas, mas o projeto foi vetado pelo arcebispo dom Duarte Leopoldo e Silva, responsável pela Arquidiocese de São Paulo, à qual o santuário estava subordinado. A emissora foi então transferida para a cidade de Cruzeiro, sendo batizada de Rádio Mantiqueira, que viria a ser a primeira emissora do Vale do Paraíba.

O projeto da Rádio Aparecida só viria a tornar-se realidade com a concessão da frequência para o santuário, em dezembro de 1950, chegando os preparativos para a instalação à sua fase final com o início das transmissões em caráter experimental, em julho de 1951. E, no dia do aniversário de coroação da imagem da Padroeira do Brasil, data em que a Igreja celebra a natividade de Nossa Senhora, era inaugurada a Rádio Aparecida. Inicialmente, a emissora tinha potência reduzida, de 100 watts, com alcance de um raio de apenas 30 quilômetros. O desejo era ter canais de alcance nacional, o que só seria concretizado com a obtenção das ondas curtas, dois anos depois, e das ondas tropicais, em 1954. Uma década mais tarde, a Rádio Aparecida, instituída como Sociedade Anônima, passou a fazer parte da Fundação Nossa Senhora Aparecida, apesar de continuar como rádio comercial.

Embora no início a programação fosse marcadamente religiosa, com transmissão de missas, orações, pregações e comentários religiosos, ela foi se diversificando e passou a 
oferecer também radionovelas, atrações musicais e até programas de auditório. Na década de 1960, o Código Brasileiro de Telecomunicações já assinalava que as emissoras de radiodifusão deveriam destinar um mínimo de 5\% do seu tempo para a transmissão de serviço noticioso (PAIVA, 2001, p.219), o que levou a rádio a investir progressivamente no jornalismo, não apenas ampliando tanto o tempo dedicado à informação, como investindo na qualidade de apresentação de seu noticiário.

As notícias esportivas já eram veiculadas há dois anos, quando, em 1958, foi criado o Departamento de Jornalismo da emissora, entrando no ar o Jornal Falado da Rádio Aparecida, de segunda a sábado, das $11 \mathrm{~h} 30$ ao meio-dia. Era a época da chamada "era de ouro do rádio”, e quem ditava o padrão era a Rádio Nacional, do Rio de Janeiro, conta o padre César Moreira em depoimento dado por ocasião dos 50 anos da rádio (MOREIRA apud PAIVA, 2001, p. 256). “A idéia dos pioneiros era copiar o modelo da Rádio Nacional”, conta o padre César em entrevista à autora, no dia 9 de julho de 2011 (APÊNDICE A).

O Jornal Falado teve vida longa na Rádio Aparecida, durando até 1987. No final da década de 1960, surgiu outro informativo, o Jornal dos Jornais, que ia ao ar das 7 às 8 horas. O radiojornal era uma síntese do conteúdo de outros órgãos de imprensa e já buscava apresentar uma análise crítica sobre o que outras rádios e jornais publicavam, conforme relata o idealizador do Jornal dos Jornais, João Boueri.

\footnotetext{
Por meio de comentários das notícias de outros jornais, buscava-se estabelecer parâmetros das diversas fontes de notícias, comentando o que se escrevia ou se falava na grande imprensa. Esta foi a primeira tentativa da rádio de opinar, de orientar os seu ouvintes (BOUERI apud MOREIRA, 1995, p.53).
}

Outro informativo, criado em meados da década de 60 foi $O$ Mundo Agora à Noite, que era levado ao ar diariamente, entre 21 e 22 horas. E havia, ainda, o Jornal Regional, transmitido apenas em ondas médias, entre 8 horas e 8h30. Em 1982, foi criado o programa Microfone Aberto, com uma hora de duração, promovendo a troca de opiniões, debates e a análise de temas da atualidade. "O programa não apenas propiciava o contato com os 
convidados ao debate de temas, mas abria também aos ouvintes a possibilidade de participar, por meio de cartas ou telefone” (Ibidem, p. 54).

Na década de 80, com a vinda de um jornalista de formação - o padre redentorista César Moreira - para a direção da rádio, o jornalismo foi reforçado como carro-chefe da emissora. A intenção era de fazer um jornalismo opinativo, dinâmico, atual e participativo. “Assuntos diversos, não raro polêmicos, como reforma agrária, Aids, drogas e violência foram temas de debates no jornalismo da Rádio Aparecida” (PAIVA, 2001, p.223). O padre César, que trabalhou nas rádios Globo, Excelsior, Record, Capital e América, em São Paulo, e na Rádio Difusora, de Goiânia, também pertencente à congregação redentorista, assumiu a direção da Rádio Aparecida nos períodos de 1981 a 1990 e de 1997 a 2005, tendo retornado em fevereiro de 2011, como diretor da Rádio e TV Aparecida ${ }^{60}$.

Fato marcante na história da rádio foi a intervenção pelas autoridades federais, em 12 de janeiro de 1969, quando os microfones da emissora foram lacrados durante 24 horas, em virtude de pronunciamento de seu então diretor, o padre Vítor Coelho de Almeida, sobre direitos humanos, ao comentar a mensagem do papa Paulo VI para o Dia Mundial da Paz.

Padre Vítor foi também um dos maiores estimuladores do Clube dos Sócios, programa criado em 1955 por um dos primeiros diretores da rádio, o padre Laurindo Rauber, para sua manutenção. Tratava-se de uma iniciativa, cuja premissa era a de fazer do ouvinte uma espécie de “sócio” da Rádio Aparecida, realizando contribuições mensais, semestrais ou anuais. Em troca, o ouvinte era convidado a participar do programa, dando depoimentos e pedindo orações. O programa, que deu origem a uma associação, chegou a contar 1,5 milhão de contribuintes em 1989, restando hoje cerca de 400 mil, segundo informação do gerente comercial da emissora, Antonio Celso Pinelli ${ }^{61}$. O clube permanece até hoje como a maior fonte de renda da emissora, segundo o gerente comercial. O modelo inovador e de sucesso foi seguido por outras rádios católicas, como a Canção Nova e a Milícia da Imaculada, que se mantém exclusivamente com a contribuição dos ouvintes.

\footnotetext{
${ }^{60}$ Em 21 de fevereiro de 2013, foi substituído na direção pelo então diretor de Programação da rádio, padre William Betônio, e na direção da TV, pelo também diretor de Programação, padre Josafá de Jesus Moraes, ambos rendentoristas. Na ocasião, o editor de Jornalismo Ederson Santos foi substituído pelo também jornalista André Costa.

${ }^{61}$ Em entrevista concedida à autora em 4 de agosto de 2011 (APÊNDICE C).
} 
A Rádio Aparecida foi também articuladora, em 1994, da formação da Rede Católica de Rádio (RCR), criada para integrar as emissoras católicas na transmissão simultânea, via satélite. A Aparecida foi desde o início uma das principais geradoras da rede, para a qual produz, atualmente, o Jornal Brasil Hoje, o Plantão RCR e o RCR em Debate, além de transmitir celebrações diretamente da Basílica de Aparecida. A filosofia da RCR, segundo conta seu atual presidente, frei João Carlos Romanini ${ }^{62}$, é a de promover a "comunhão das rádios católicas”, no sentido de repartir as verbas publicitárias entre as rádios, com o intuito de auxiliar as emissoras que apresentem maiores dificuldades de sobrevivência.

Atualmente, a Rádio Aparecida opera em ondas médias, ondas curtas e FM, e sua programação pode ser ouvida em território nacional, em uma rede formada por 80 emissoras. Em entrevista à revista Paróquias \& Casas Religiosas ${ }^{63}$, em 2007, o então diretor da rádio, padre Inácio Medeiros, estimava a audiência da emissora em mais de 2 milhões de ouvintes, atingindo 3,5 mil cidades em todo o País.

O editor Ederson Santos ${ }^{64}$ detalhou a programação jornalística da rádio: das 7 horas às 7h30, de segunda a sábado, o Jornal Brasil Hoje, transmitido pelas emissoras da Rede Católica de Rádio, para ondas médias, ondas curtas e via satélite; o Jornal dos Jornais $1^{a}$ Edição, vai ao ar de segunda a sexta, das 7 h30 às 8 horas, para AM, ondas médias e ondas curtas; às 11 horas, de segunda a sexta, o Jornal Regional, que, segundo o editor, é um dos programas mais tradicionais e de maior audiência na região do Vale do Paraíba, no horário das 11 horas ao meio-dia.

A emissora tem um programa esportivo, o 820 nos Esportes, de segunda a sexta, das 17 horas às $17 \mathrm{~h} 30$, em ondas médias. Também de segunda a sexta, das $17 \mathrm{~h} 30$ às 18 horas, entra no ar o Jornal dos Jornais $2^{a}$ Edição, que vai para ondas médias, ondas curtas e também via satélite. O Plantão RCR, produzido para a Rede Católica de Rádio, boletim de cinco minutos, é veiculado de manhã e no período da tarde: às 8h55, 9h55, 10h55, 13h55, 14h55, 15 h55 e 16h55. "Esses são os noticiários principais que nós temos. Agora, claro, entre um jornal e outro, temos uma série de boletins, que a gente produz tanto para AM, FM e ondas curtas”,

\footnotetext{
${ }^{62}$ Em entrevista à autora, concedida no dia 22 de fevereiro de 2013 (APÊNDICE G).

${ }^{63}$ DE ANGELIS, Sandra. Complexo Empresarial com Foco no Cliente. In Paróquias \& Casas Religiosas, Ano 2 No 7 - julho-agosto 2007. São Paulo: Promocat.

${ }^{64}$ Em entrevista concedida à autora, no dia 4 de agosto de 2011 (APÊNDICE B).
} 
relata Santos. A redação da emissora é composta por oito profissionais, entre redatores, repórteres e um editor, todos formados em jornalismo. A Rádio Aparecida conta hoje com um total de 67 funcionários.

\subsection{Rádio Canção Nova: opção pela comunicação}

No livro Canção Nova, uma Obra de Deus - Nossa história, identidade e missão (2000), o padre salesiano Jonas Abib descreve o caminho que seguiu para a formação e consolidação da Comunidade Canção Nova. Sinais e mensagens o levaram a caminhos e pessoas que, por sua vez, conduziram o líder religioso e seu grupo a constituírem o que viria a tornar-se um dos maiores pólos de comunicação do País: o Sistema Canção Nova de Comunicação, que abrange rádio AM e FM, TV, editora e portal de internet. "Deus provou; não dá para negar. Ele nos escolheu para trabalhar nos meios de comunicação, para evangelizar por meio deles” (ABIB, 2000, p.94).

Após a fundação da comunidade, em 1978, em um local batizado de Chácara Santa Cruz, em Cachoeira Paulista, onde se dedicava ao trabalho de evangelização por meio de retiros espirituais, nos quais reunia especialmente grupos de jovens, padre Jonas - posteriormente agraciado com o título honorífico de "monsenhor" - começou a despertar para o potencial dos meios de comunicação na missão de evangelizar da Canção Nova.

\footnotetext{
Não sabíamos que nossa existência estava ligada a trabalhar nesses meios, tanto assim que nos dois primeiros anos de comunidade nos interrogávamos muito. Perguntávamos: por que Deus nos quer vivendo em comunidade? Será que é só para estudar sua palavra? Para rezar e trabalhar em encontros e fazer palestras? No final do segundo ano, começaram os sinais de Deus nos encaminhando para os meios de comunicação (Ibidem, p. 83).
}

$\mathrm{Na}$ época, o mais moderno recurso de tecnologia de que o grupo dispunha era um gravador, e era esse o instrumento mais usado para transmitir a mensagem da Canção Nova, inicialmente em encontros e palestras, e depois pelo rádio. Motivado pela missão de propagar a sua mensagem de todas as formas que estivessem ao seu alcance, monsenhor Jonas Abib 
fazia cópias de suas fitas e saía distribuindo o material pelas emissoras de rádio que o recebessem, segundo descreve em reportagem a jornalista Sandra de Angelis (2008) ${ }^{65}$.

As gravações originais traziam ruídos do ambiente, falhas sonoras, mas não lhe faltava a determinação de prosseguir em uma atitude de levar sua mensagem a quem quisesse recebê-la. E como todo líder encontra seus seguidores pelo caminho, com o padre salesiano não foi diferente, já que seu propósito era levar à frente o sonho de um projeto pastoral de evangelização calcado nos meios de comunicação (Idem, 2008).

O primeiro programa de monsenhor Jonas foi ao ar pela rádio Mantiqueira, em Cruzeiro, seguida pela rádio Cultura de Lorena, depois pela Bandeirantes, de Cachoeira Paulista, e pela Mineira do Sul, de Passa Quatro, Minas Gerais. Entretanto, cientes da necessidade e imbuídos da determinação de adquirir uma emissora própria, o religioso e seu grupo empreenderam esforços para adquirir uma emissora própria, o que se tornou realidade no dia $1^{\circ}$ de abril de 1980, com a aquisição da Rádio Bandeirantes, de Cachoeira Paulista.

Um mês depois, em 25 de maio, tiveram início as transmissões da Rádio Canção Nova AM, com o programa diário Alô, Bom Dia - apresentado pelo monsenhor e por outra fundadora da Comunidade Canção Nova, Luzia Santiago -, em que falavam sobre temas evangelizadores que se encaixavam no cotidiano das pessoas, fazendo reflexões sobre o Evangelho para cada dia.

No início, a rádio operava com 250 watts de potência, atingindo pouco além da cidade de Cachoeira Paulista, e não transmitia 24 horas de programação, o que só viria a tornar-se realidade em 1993. Ao longo de três décadas, a Rádio Canção Nova passou por uma expansão que possibilita à emissora atingir, hoje, grande parte do território brasileiro e o exterior, transmitindo em ondas médias, curtas e tropicais. Na América Latina, a programação chega ao Paraguai, México, Honduras, El Salvador, Guatemala e Nicarágua, segundo informa o site

\footnotetext{
${ }^{65}$ DE ANGELIS, Sandra. O Poder da Mensagem. In: Paróquias \& Casas Religiosas, Ano 2 № 11 - março-
} abril 2008. São Paulo: Promocat. 
www.cancaonova.com ${ }^{66}$. A Canção Nova tornou-se rede em 1995, quando começou a operar via satélite, contando atualmente com 28 emissoras no Brasil.

Apesar de ter concessão comercial, desde o início, a rádio é mantida integralmente por meio de contribuições de ouvintes e simpatizantes da comunidade. Em um modelo similar ao Clube dos Sócios, da Rádio Aparecida, em setembro do ano de fundação, a emissora iniciou, em sua grade de programação, o programa Clube do Ouvinte - que vai ao ar hoje de segunda a sábado das 9h15 às 11 horas -, em que se abria espaço à participação do público para fazer relatos sobre sua experiência ao conhecer a Canção Nova, ao mesmo tempo em que dava origem ao projeto de arrecadação de doações para a manutenção da rádio.

O programa ainda está no ar e foi constituído um departamento, hoje chamado Clube da Evangelização, que arca com manutenção não apenas da rádio, mas de toda a Canção Nova. Por meio de outro programa, Deus Proverá, transmitido atualmente às quintas-feiras, das 13 horas às 14 horas, a Canção Nova apresenta as obras e os eventos que promove, além de informar ao sócio como está o andamento da meta financeira de cada mês.

A Fundação João Paulo II, entidade mantenedora do Sistema Canção Nova de Comunicação, é dirigida por alguns dos membros fundadores da comunidade religiosa. Além do monsenhor Abib, que é presidente do Conselho Deliberativo, estão à frente da fundação o casal Luzia Santiago e Wellington Silva Jardim, como diretores-executivos, e Filipe Garcez Jardim, como vice-diretor executivo. A fundação atualmente conta com cerca de 1,4 mil colaboradores.

A estrutura de todo o complexo constituiu-se em torno do local de origem da comunidade, em Cachoeira Paulista, abrangendo atualmente uma área de 45 hectares, onde estão instaladas as sedes das rádios AM e FM, da TV, uma agência de publicidade exclusiva, o Departamento de Audiovisual da Canção Nova (Davi), um centro de eventos com capacidade para 70 mil pessoas, uma escola de ensino fundamental e médio e, mais recentemente, a Faculdade Canção Nova, que oferece cursos de Administração, Filosofia, Jornalismo, Rádio e TV. Além da sede em Cachoeira Paulista, a Canção Nova conta com 22

${ }^{66}$ Acesso em 16 de maio de 2013. 
casas de missão em todo o Brasil e seis no exterior (Paraguai, Estados Unidos, Portugal, Itália, França e Israel).

O jornalismo do Sistema Canção Nova de Comunicação, integrado hoje em um departamento com cerca de 40 profissionais, começou com a aquisição da Rádio Bandeirantes, de Cachoeira Paulista, em cumprimento à exigência legal de dedicar obrigatoriamente $5 \%$ da programação ao serviço noticioso.

A princípio eram feitos boletins de hora em hora, e as notícias eram geradas com o resumo de jornais escritos, que só chegavam a Cachoeira Paulista mais tarde que nas capitais; por esse motivo o jornal só ia ao ar por volta das 8 horas da manhã, depois da exibição dos jornais locais ${ }^{67}$.

O departamento, que está sediado em Cachoeira Paulista, produz notícias simultaneamente para a TV, a rádio e o portal de internet. Nesse trabalho, conta com correspondentes das emissoras locais e colaboradores que atuam nas casas de missão espalhadas pelo Brasil e pelo exterior, como relata a editora do Jornal Canção Nova $2^{a}$ Edição, Catarina Jatobá ${ }^{68}$.

As casas de missão são as nossas filiais, porque a gente tem aqui a central, em Cachoeira Paulista, e as nossas sucursais, que mandam material. Por exemplo: no Rio de Janeiro está acontecendo alguma coisa. O pessoal produz e manda o áudio para a gente. Curitiba, nós temos uma repórter lá também, que sempre manda matéria, a Fabiana Sá. Brasília tem a Gisele Pires. No Rio, tem o Áureo Ameno. Em Pernambuco, tem o Josenildo Pedro. São correspondentes. Nós temos também, fora, em Roma, quando precisa, o pessoal sempre dá uma ajuda. A Canção Nova está lá também. Os correspondentes de fora são mais esporádicos. Os de dentro, são mais fixos. (...) Onde tem rádio, a gente consegue uma ajuda das pessoas que trabalham na equipe da rádio lá para enviar as matérias para a gente, mas não é aquela coisa fixa, todos os dias, porque depende da demanda também, depende do assunto.

Já a equipe de jornalistas da Rádio Canção Nova, à época da entrevista, era formada por cinco pessoas. Além da editora Catarina Jatobá, jornalista profissional, a equipe era integrada pelas produtoras Flávia Pereira (apresentadora do Jornal Canção Nova $1^{a}$ Edição) e Roselaine

\footnotetext{
${ }^{67}$ Disponível em http://wiki.cancaonova.com. Acesso em 16 de maio de 2013.

${ }^{68}$ Em entrevista concedida à autora no dia 10/08/2011 (APÊNDICE D).
} 
Iria - ambas missionárias da Canção Nova -, pelo técnico Paulo Guedes e pelo apresentador do Jornal Canção Nova $2^{a}$ Edição, o também jornalista Reinaldo César.

A editora detalha a programação jornalística da rádio à época da entrevistas: duas edições, de segunda a sexta, do Jornal Canção Nova, a primeira das 6 h30 às 7 horas, e outra, das 13 horas às $13 \mathrm{~h} 30^{69}$. Ao longo do dia, eram também veiculados boletins, com duração de cinco minutos - às 10h05, 14h35 e às 17 horas. À noite, mais um boletim, às 20 horas. "E nós temos também um programa que vai ao ar aos domingos, às 6h30, que se chama Notícias da Igreja, que é o resumo das notícias semanais da Igreja no Brasil e no mundo”, acrescenta.

O editor-executivo do Departamento de Jornalismo, Wallace Andrade, define como é, em sua opinião, fazer um “jornalismo a serviço da vida e da esperança”, que é o lema da Canção $\mathrm{Nova}^{70}$. “Antes de sermos jornalistas, somos católicos. (...) os jornalistas da Canção Nova trabalham para levar (...) mais que notícias, um olhar de fé e esperança, sempre a serviço da vida", diz o editor. "Num país como o Brasil, com tantas dificuldades e tragédias (...), buscamos mostrar para as pessoas que 'ainda tem jeito', apesar do mundo ter tantas contradições”, ressalta o editor-executivo.

Andrade conta que uma de suas experiências de trabalho mais marcantes foi em Cachoeira do Itapemirim, no Espírito Santo, onde fez uma reportagem de Natal (para a TV Canção Nova ${ }^{71}$ ) acompanhando um catador de papel. Conta ele:

Chegamos à casa dele e o que ele tinha para comer, naquele dia de Natal, era um prato de arroz com feijão. A despensa dele, que era uma geladeira velha, não tinha praticamente nada. Mas naquela casa víamos uma família feliz, de Deus, que tinha como norte o Salmo 23, "o Senhor é meu Pastor e nada me faltará”. (...) Aquela família, apesar de toda dificuldade, tinha esperança e transmitia isso àqueles que estavam ao seu lado. Esse é o propósito do jornalismo Canção Nova: fazer com que cada vez mais as pessoas possam ser exemplo de fé e perseverança, mesmo em meio à dureza da vida.

\footnotetext{
69 No primeiro semestre de 2012, a segunda edição do radiojornal, passou para o horário das 12 horas às $12 \mathrm{~h} 30$, de segunda a sexta.

${ }^{70}$ Disponível em http://noticias.cancaonova.com/noticia.php?id=284981. Acesso em 17 de maio de 2013.

${ }^{71}$ A TV Canção Nova começou suas transmissões em 1989 e tornou-se a maior emissora católica de televisão do Brasil. Hoje conta com seis geradoras e 350 retransmissoras no Brasil. Seu sinal via satélite cobre a América do Sul, Estados Unidos, Europa, Oriente Médio e Ásia. Disponível em http://www.cancaonova.com/portal/canais/tvcn/tv/tvi.php?id=7. Acesso em 17 de maio de 2013.
} 


\subsection{Metodologia de análise do perfil dos radiojornais}

Para a análise dos programas, foram selecionadas amostras de dois radiojornais, um de cada emissora: o Jornal Brasil Hoje (JBH), transmitido de segunda a sábado, das 7 horas às 7h30 pela Rádio Aparecida AM (para efeito desta pesquisa, foram selecionadas as edições de segunda a sexta), e o Jornal Canção Nova $2^{a}$ Edição, que vai ao ar de segunda a sexta, das 12 horas às 12h30, pela Rádio Canção Nova AM. A seleção esteve focada no período de 30 de julho a 31 de agosto de 2012, tendo sido escolhida uma edição de cada dia da semana em semanas subsequentes. Dessa forma, foram gravados 10 radiojornais, sendo um de cada dia da semana, de segunda a sexta, ao longo de cinco semanas seguidas (segunda-feira, dia 30 de julho de 2012; terça-feira, dia 7 de agosto de 2012; quarta-feira, dia 15 de agosto de 2012; quinta-feira, dia 23 de agosto de 2012; e sexta-feira, dia 31 de agosto de 2012).

Essa opção teve por objetivo evitar a prevalência de um tema (“suíte”, no jargão jornalístico) do noticiário que esteja em destaque numa determinada semana. O período foi escolhido também em virtude ser uma época em que é menor a ocorrência de datas e grandes eventos religiosos, no intuito de evitar nos radiojornais uma eventual preponderância de notícias sobre a Igreja Católica.

À época das gravações, o fato político que mobilizava o país era o julgamento do mensalão (Ação Penal 470) pelo Supremo Tribunal Federal. O julgamento, que teve início no dia 2 de agosto e prosseguiu até 17 de dezembro de 2012, foi considerado o mais importante da história do STF, tendo condenado 25 réus (e absolvido 12) pelo envolvimento em um esquema de compra de votos no Congresso Nacional durante os primeiros anos do governo do ex-presidente Luiz Inácio Lula da Silva. Os fatos mais relevantes no período foram a leitura da denúncia pelo procurador-geral da República, Roberto Gurgel, a apresentação do relatório pelo ministro relator, Joaquim Barbosa, as sessões de exposição de defesa por parte dos advogados dos réus e o início dos votos dos ministros.

O período de análise marcava também o começo da movimentação, divulgação de pesquisas e consolidação de alianças políticas para as eleições municipais em todo o País, cujo primeiro turno seria realizado no dia 7 de outubro de 2012 e o segundo, no dia 28 do mesmo mês. Outro fato em destaque nas semanas de gravação foram as Olimpíadas de 
Londres (27 de julho a 12 de agosto de 2012), em que o Brasil obteve 17 medalhas (3 de ouro, 5 de prata e 9 de bronze $)^{72}$.

Após o período de gravações, foi transcrita e analisada cada uma das 10 edições dos radiojornais, sendo todas enquadradas em fichas de análise criadas especialmente para esse exame. Cada notícia foi analisada segundo os seguintes parâmetros: Título; Editoria; Fontes (se entrevistada ou citada; quando entrevistada, discriminava-se o tempo de cada sonora); Tempo; e, por fim, respostas à pergunta: “Utiliza alguma fonte/referência religiosa?”. Para a análise, cada notícia foi decupada (contabilizados os minutos) dentro de cada edição, observando-se a que editoria pertencia, quantos minutos/segundos tinha, quais foram as fontes consultadas e o tempo das sonoras (no caso de entrevistas).

Em seguida, observou-se o percentual de cada notícia e de cada editoria nas edições de cada um e do total dos 10 radiojornais. A partir daí, foi possível estabelecer a porcentagem de cada editoria em cada um e no tempo total dos radiojornais. Para efeito das operações estatísticas, descontou-se do tempo total a parte de produções adicionais, como vinhetas e chamadas, considerando-se apenas o tempo de noticiário propriamente dito.

O objetivo da análise foi o de traçar o perfil dos dois jornais das emissoras católicas, investigando de que forma o noticiário dessas rádios se apresenta ao público, sendo observada, em primeiro lugar, sua estruturação em termos do percentual de tempo das editorias observadas. Essas foram definidas segundo a própria denominação dos responsáveis pelos radiojornais, como Política, Economia, Geral, Esporte e Editorial no caso do $J B H .^{73}$ E, no caso do JCN, Política, Economia, Internacional e Geral (no caso específico desse radiojornal, foram consideradas notícias de Geral todas as que não se enquadravam nas editorias anteriores, mas apareciam agrupadas sob vinhetas do próprio telejornal, como Serviço, Saúde, Educação, Transportes, Rodovias e Previsão do Tempo).

\footnotetext{
72 Na amostra analisada, a parcela dedicada ao esporte foi significativamente menor no jornal da Rádio Aparecida, ocupando somente 1,94\% do noticiário, contra 13,99\% no jornal da Canção Nova, pelo fato de a Aparecida ter um programa exclusivamente dedicado a notícias esportivas, o 820 nos Esportes, transmitido de segunda a sexta das 17 horas às $17 \mathrm{~h} 30$.

${ }^{73}$ Segundo explica o editor Ederson Santos, o radiojornal é dividido em três blocos: Política, Economia e Geral. No terceiro bloco entram todas as notícias não enquadradas nas editorias anteriores, incluindo o Editorial, que encerra a edição (APÊNDICE B).
} 
No $J B H$, foram ainda separadas as partes informativa e opinativa, aplicando a clássica distinção de José Marques de Melo (1985) entre jornalismo informativo (registro claro e objetivo dos fatos e acontecimentos, caracterizado pela observação) e jornalismo opinativo (emissão de opinião diante das notícias, caracterizado pelo aconselhamento).

A fim de identificar o espaço que as notícias sobre a Igreja Católica ocupavam nos dois noticiários, essas foram agrupadas, para efeito deste estudo, em uma editoria separada, chamada de Religião. Tais notícias aparecem sempre no último bloco do $J B H$ e, no caso do JCN, abrem o noticiário, entrando com vinhetas específicas, como Papa ou Angelus.

Foram contabilizadas duas notícias de Religião no $J B H$, ambas no dia 30/07/2012: $O$ movimento foi intenso em Aparecida nesse fim de semana (com 4’09) e Arquidiocese do Rio de Janeiro recebe imagem de Nossa Senhora Aparecida para Jornada Mundial da Juventude, no Rio, em 2013 (com 1’59). O tempo total de notícias de Religião no JBH foi de 6’08 ou 5,67\% do tempo de noticiário analisado.

No JCN, foram encontradas 14 notícias enquadradas na editoria de Religião. No dia 30/07/12: Papa assegura que Eucaristia é encontro do homem com Deus (com 1'49); Papa pede fim da violência na Síria e no Iraque (com 1’13); e Papa Bento XVI expressou seu pesar pela morte do presidente de Gana (com 0'29); no dia 07/08/12: Aumenta a expectativa dos católicos e da Igreja libanesa pela visita de Bento XVI ao país (com 1’15); Congresso teológico, mais uma iniciativa pelo Ano da Fé (com 1’41); Estão abertas as inscrições para o Seminário Nacional da Juventude (com 1'14). No dia 15/08/12: Na oração mariana do Angelus, papa afirma que assunção nos indica o futuro da humanidade (com 2'11); A festa da Aventura da Cruz será o momento de apresentação do hino oficial da JMJ Rio 2013 (com 1’05); Cidade que hospeda o papa no verão está vivendo com muita expectativa a tradicional procissão de barcos (com 1’06); Em nome do papa Bento XVI, o secretário de Estado, cardeal Tarcisio Bertone, enviou um telegrama de condolências ao presidente da República Federal democrática da Etiópia (com 0’24); Na manhã de quinta-feira, foi realizada, na sede da Conferência Nacional dos Bispos do Brasil, em Brasília, a missa com os parlamentares (com 0’41); e Vai ser realizado, de 22 a 25 de outubro, em Belo Horizonte, o segundo Seminário Igreja e Bens Culturais (com 0’24). E, no dia 31/08/12: Vaticano defende hoje a necessidade de uma boa governança mundial no dia em do respeito ao acesso à água (com 1’17); Arquidiocese de Milão deu hoje conta do agravamento do estado de saúde do cardeal 
Carlo Maria Martini, de 85 anos (com 0’53). Ao todo, foram 15’42 de notícias de Religião, o que representou 14,49\% do noticiário da Canção Nova.

Também neste último caso, do $J C N$, verificou-se que a emissora costuma incluir no radiojornal notícias sobre atividades e eventos da Fundação João Paulo II, mantenedora da Comunidade Canção Nova, da Faculdade Canção Nova, bem como informações sobre campanhas de arrecadação de contribuições dos ouvintes à instituição. Tais notícias foram separadas em uma editoria classificada, para efeito deste estudo, como Institucional - para análise futura que apontaria o peso das informações sobre a Igreja Católica nesse noticiário.

No caso do $J B H$, não foram encontrados tais tipos de notícias de promoção ou divulgação da Fundação Nossa Senhora Aparecida, à qual pertence a rádio, ou do Santuário Nacional de Aparecida. Embora tenha sido observada uma notícia sobre acontecimentos no Santuário, Movimento foi intenso em Aparecida nesse fim de semana, no dia 30 de julho de 2012, que tratou de celebrações em comemoração à fundação de diversas paróquias, ocupando um tempo de 4’09 (3,84\% do tempo total de noticiário), esta entrou na editoria de Religião, pelo fato de noticiar um festejo oficial do calendário católico. A notícia contava com sonora de 3’03 de dom Raymundo Damasceno Assis, arcebispo de Aparecida e presidente da Conferência Nacional dos Bispos do Brasil (CNBB).

Outra linha de análise que permitiu identificar a primazia da presença da Igreja Católica nos noticiários foi a identificação de quatro notícias (três no $J B H$ e uma no $J C N$ ) nas quais se tomou como referência ou foi entrevistada uma fonte ligada à instituição, e que apareciam em outra editoria. Essas não foram separadas em uma editoria específica, uma vez que foram encontradas em Política tanto no caso da Rádio Aparecida quanto no da Canção Nova ${ }^{74}$. Apenas observaram-se suas características e tempo, a fim de contabilizá-las ao lado das notícias da editoria de Religião (JBH e $J C N)$ e das notícias Institucionais (JCN).

\footnotetext{
${ }^{74}$ No JBH: Brasília se prepara para o Julgamento do Mensalão (1’59), que teve como fonte citada a professora Maria Celina D’Araújo, do Departamento de Sociologia e Política da Pontifícia Universidade Católica do Rio de Janeiro, instituição ligada à Igreja, no dia 30/07/12; Presidente da CNBB diz que julgamento do mensalão deve servir de alerta aos políticos (1'31”), com sonora de dom Raymundo Damasceno Assis (1'27); e Indígenas e movimentos sociais se unem para pedir ao governo paralisação de obras em hidrelétricas no Pará (2’04), com sonora do padre Edilberto Sena, diretor da Rádio Rural de Santatém (0’45), ambas no dia 31/08/2012. No JCN: STF condena João Paulo Cunha, Pizzolato e Valério, e conclui primeira parte do mensalão (1'43) no dia 31/08/2012, com sonora de dom Raymundo Damasceno Assis (0’44).
} 
No caso do $J B H$, os artigos que integravam a seção Editorial também foram contabilizados nessa análise posterior, uma vez que, apesar de abordarem temas de editorias diversas, como Política (dois artigos encontrados na amostra), Economia (um artigo), Religião (um artigo) e Geral (um artigo) ${ }^{75}$, também podiam ser considerados um reforço da presença da Igreja no noticiário, uma vez que representam a opinião da Rádio Aparecida, uma instituição católica.

Em um segundo momento, procurou-se identificar quais as fontes ouvidas no noticiário, segundo a classificação de Lage (2001, pp.63-67). Dessa forma, foram observadas entrevistas de fontes oficiais, especificadas como: governamentais, legislativas, judiciais, empresariais e sindicais, às quais foi agregada a categoria eclesiais, a fim de observar-se o tempo reservado especificamente a representantes da Igreja Católica nos noticiários. Além dessas, foi observada a presença de fontes independentes (organizações não-governamentais), especialistas e protagonistas (quando a própria fonte é a notícia). Nessas categorias, foram discriminadas as fontes entrevistadas (que mereceram sonoras, com os respectivos tempos), destacando-as das citadas (apenas consultadas). Dessa forma, foi possível identificar no noticiário o tempo reservado a determinados tipos de fontes, em especial, as eclesiais, que pesariam no cômputo do conteúdo católico dos radiojornais.

\subsection{Percentual das editorias e conteúdo religioso dos radiojornais}

Na análise do Jornal Brasil Hoje, cujo tempo total considerado foi de 1h49', verificou-se que as notícias que mais ocuparam tempo do noticiário foram as da editoria de Política (27 notícias ao todo; representando 31,03\%; com um total de 33’31), seguida pela editoria de Geral (25; 27,88\%; com 30’07), depois por Economia (23; 23,58\%; com 25’28’), em seguida Editorial (5; 9,87\%; com 10’40), depois Religião (2; 5,67\%; com 7’08) e, por fim, Esporte (1; 1,94\%; com 2’06), conforme é demonstrado no Gráfico 1.

\footnotetext{
${ }^{75}$ Política: Nunca Antes na História deste País, com 2’00, no dia 30/07/2012 e Desperdício de Dinheiro Público, com 1'55, no dia 23/08/2012; Economia: O consumidor irracional, com 2'03, no dia 07/08/2012; Religião: Confusões no Vaticano, com 2'13, no dia 15/08/2012; e Geral: Projetos de Coleta Seletiva de Lixo para Supressão de Lixões Insalubres, com 2’29, no dia 31/08/2012.
} 


\section{Jornal Brasil Hoje - Editorias}

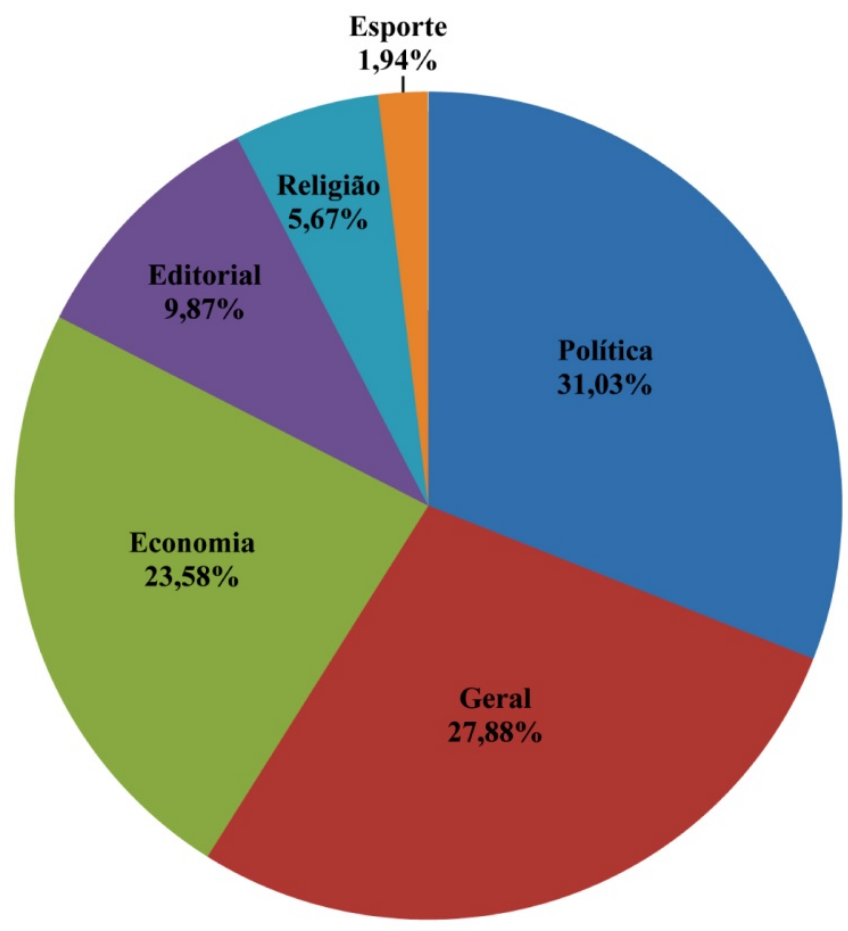

Gráfico 1: Jornal Brasil Hoje - Editorias. Tempo total de 1h49'. Política: 27 notícias, 3'31. Geral: 25 notícias, 30’07. Economia: 23 notícias, 25’28. Editorial: 5 notícias, 10’40. Religião: 2 notícias, 7’08. E Esporte: 1 notícia, 2’06.

Como o radiojornal $(\mathrm{JBH})$ tem o diferencial de apresentar uma parte informativa e outra opinativa (representada pelos editoriais), decidiu-se analisar o percentual que cada uma dessas partes ocupava no noticiário geral (Gráfico 2). 


\section{$J B H$ - Informativo e Opinativo}

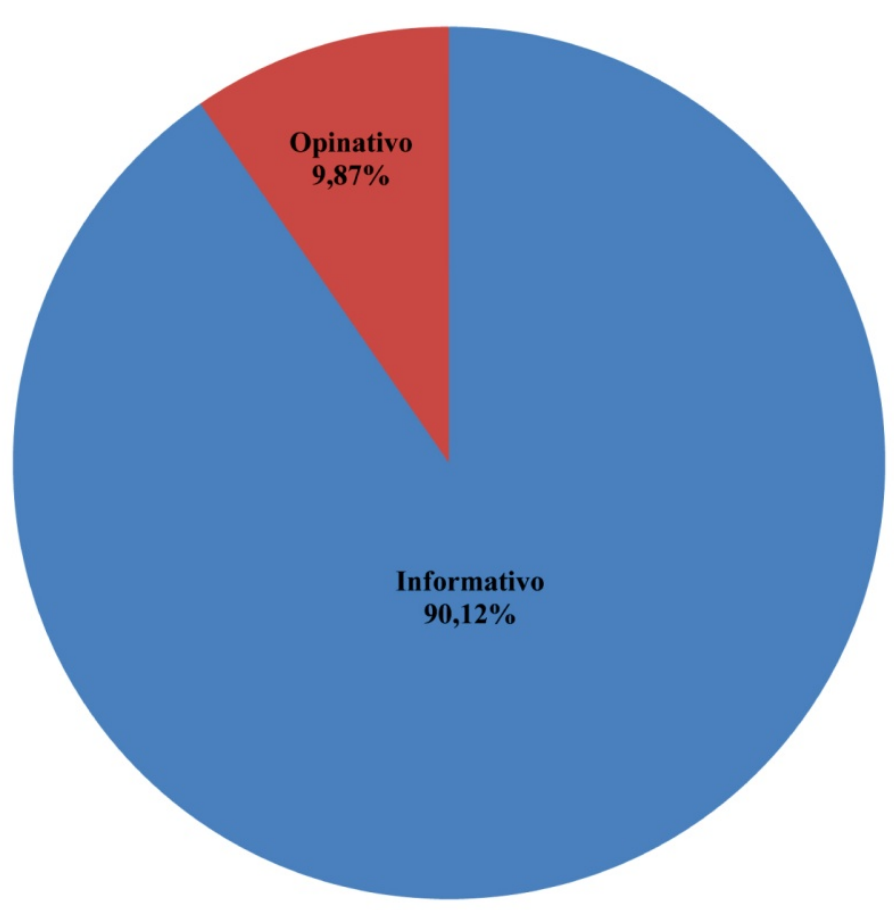

Gráfico 2: $\boldsymbol{J} \boldsymbol{B} \boldsymbol{H}$ - Informativo e Opinativo. Tempo total do noticiário informativo foi de 1h37'20; e do opinativo, 10'40.

O noticiário informativo ocupou 90,12\% do tempo jornalístico (total de 1h37’20), dos quais 10’23 (o equivalente a 12,94\% do total informativo) transmitiram notícias sobre Religião ou tendo alguma referência ou fonte religiosa - o que representou 9,61\% do tempo do radiojornal (Gráfico 3). 


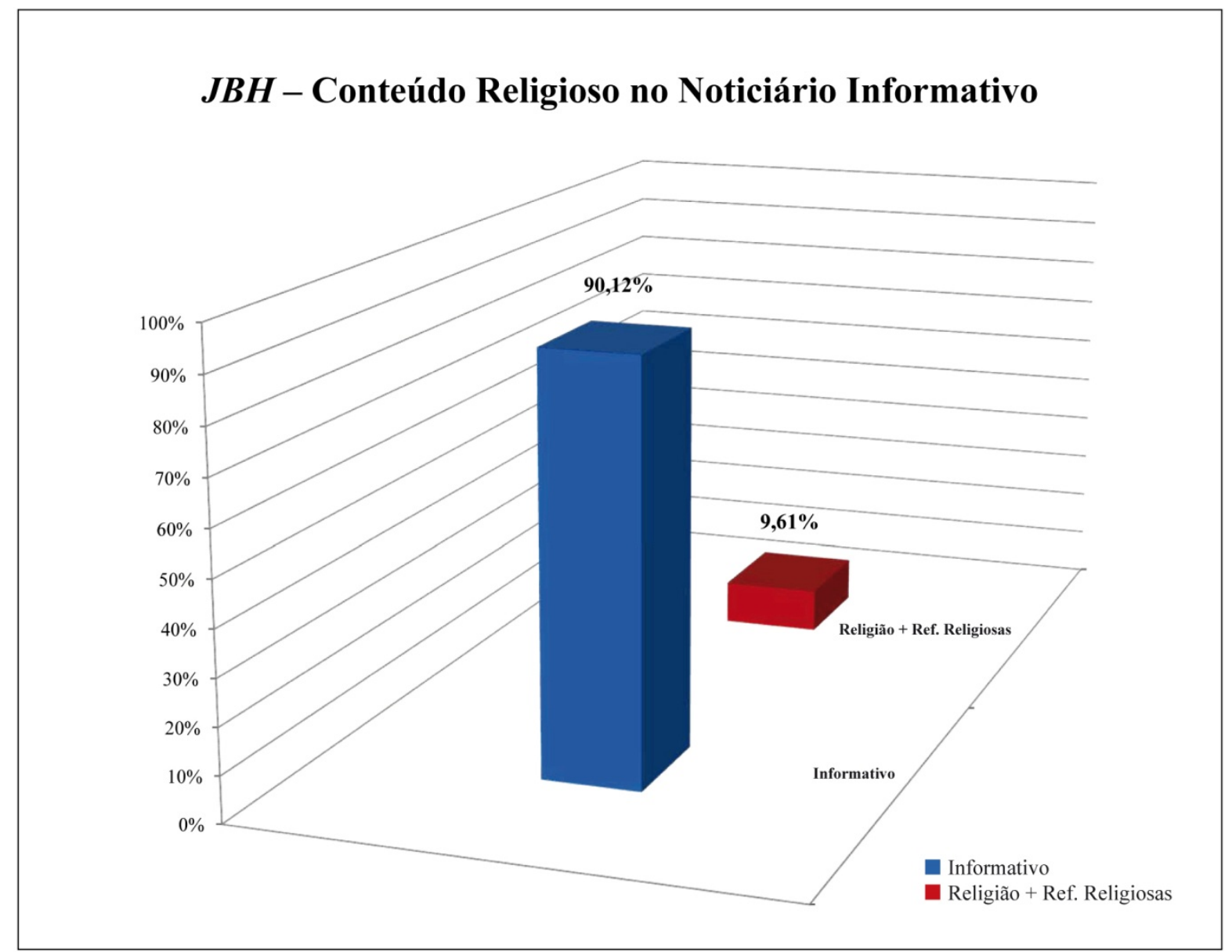

Gráfico 3: $\boldsymbol{J B H}$ - Conteúdo Religioso no Noticiário Informativo. O noticiário informativo ocupou 1h37'20, dos quais 10'23 transmitiram notícias sobre Religião e/ou com alguma fonte religiosa.

O noticiário opinativo ocupou 9,87\% do tempo do noticiário, com $10^{`} 40^{76}$. Do total opinativo, os editoriais sobre Política ocuparam a maior parte do tempo (2 artigos somando 3'55, o que representa 36,71\% do tempo de opinativo), seguidos por Geral (1 artigo de 1'29 ou 23,28\% do tempo de opinativo); Religião (1 artigo de 2’13 ou 20,78\%) e Economia (1 artigo de 2’03 ou 19,21\%), como se pode ver no Gráfico 4.

${ }^{76}$ Ver nota anterior, na página 82. 


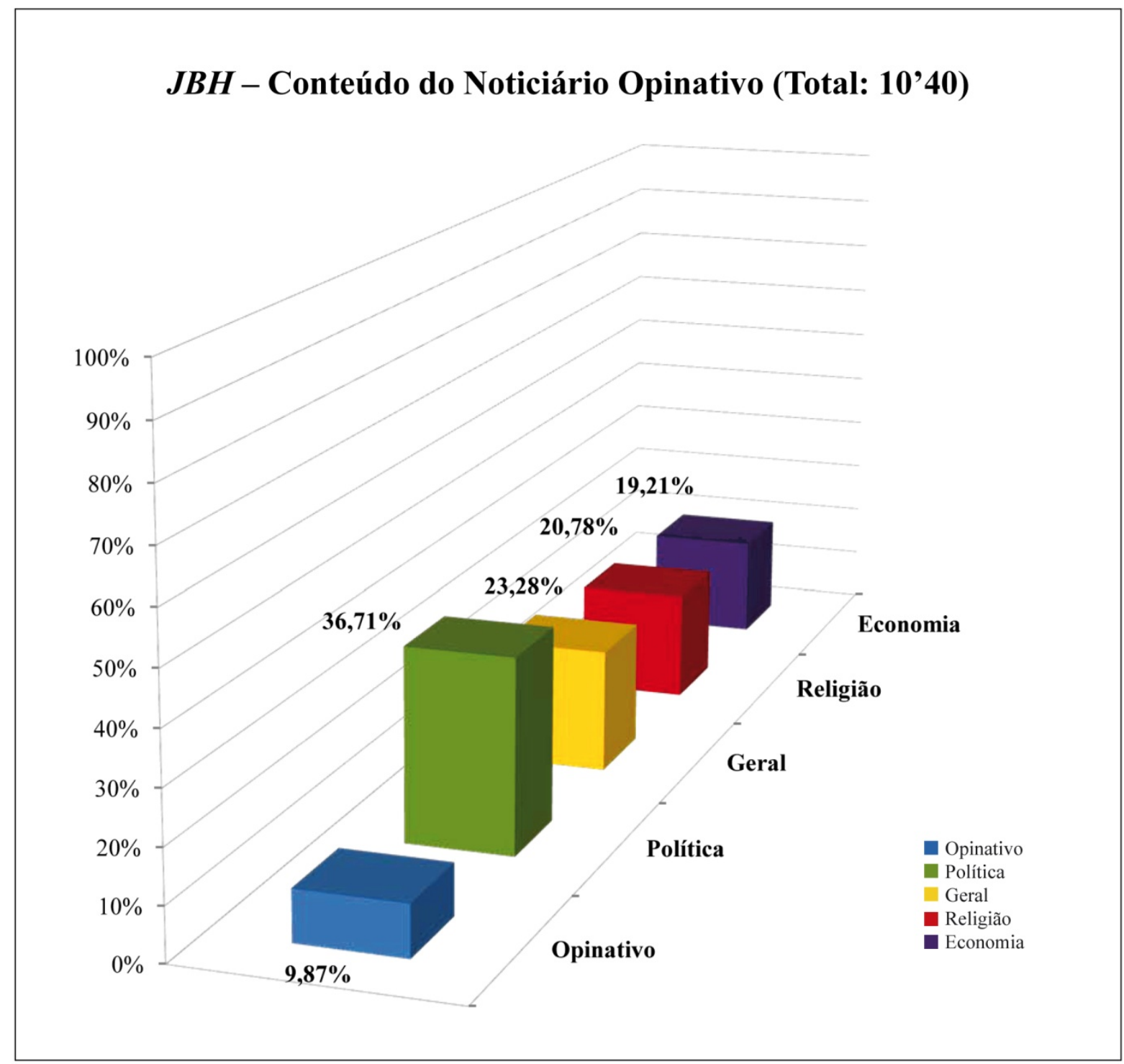

Gráfico 4: $\boldsymbol{J B H}$ - Conteúdo do Noticiário Opinativo. Do total opinativo (10’40), os editoriais sobre Política ocuparam a maior parte do tempo (2 artigos somando 3'55); seguidos por Geral (1 artigo de 1'29); Religião (1 artigo de 2'13); e Economia (1 artigo de 2'03).

Em relação ao tempo total do noticiário, obtêm-se os seguintes percentuais do noticiário opinativo: Política, 3,62\%; Geral, 2,29\%; Religião, 2,05\%; e Economia, 1,89\% (Gráfico 5). 


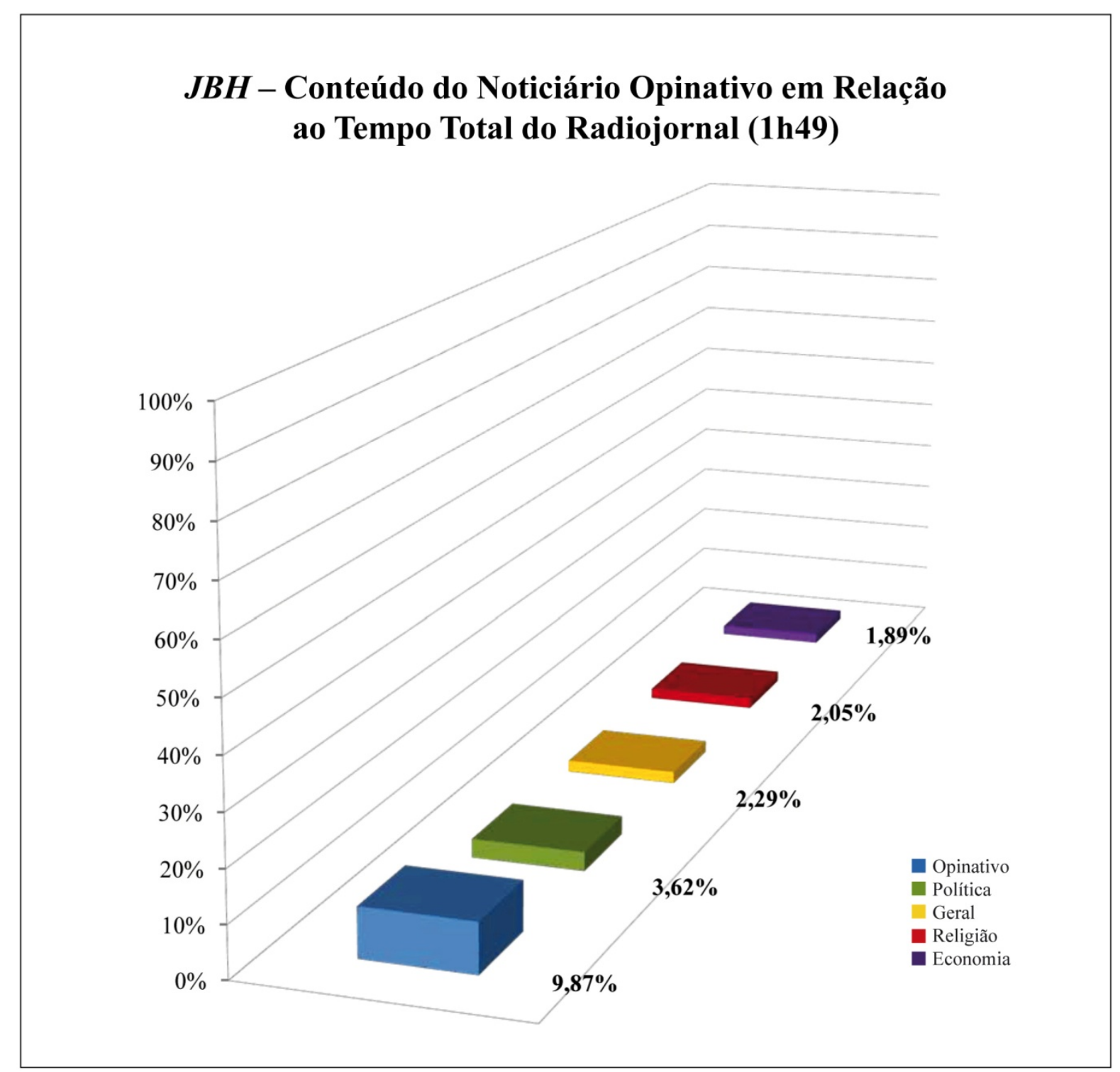

Gráfico 5: JBH - Conteúdo do Noticiário Opinativo em Relação ao Tempo Total do Radiojornal. Em relação ao tempo total da amostra (1h49), obtêm-se os seguintes percentuais do noticiário opinativo: Política - 3,62\% (3’55); Geral - 2,29\% (1’29); Religião - 2,05\% (2’13); e Economia - 1,89\% (2’03).

Esse último levantamento e os resultados obtidos foram decisivos para a análise posterior, que buscaria identificar o "peso" da presença da Igreja Católica no noticiário, uma vez que, abordando o tema Religião ou não, o editorial é sempre um espaço dedicado à opinião da instituição sobre assuntos correntes e pode, portanto, ser considerado um bloco de tempo indicativo da prevalência da Igreja no radiojornal. 
No $J B H$, foram ainda detectadas, no período de amostragem, duas notícias da editoria de Política e uma de Geral que utilizavam fontes (uma citada e três entrevistadas) ligadas à Igreja Católica. As três notícias, embora estivessem em outras editorias, foram contabilizadas como apresentando referências à Igreja Católica, pois utilizavam fontes ligadas à instituição.

Dessa forma, no noticiário informativo do $J B H$, somando-se as notícias exclusivamente sobre Religião (6’08), mais as notícias que utilizavam fontes ligadas à Igreja Católica (3’30), obtém-se um total de 10’23, o que equivale a 12,94\% do total de noticiário informativo e a 9,61\% do radiojornal. Caso seja considerado nessa análise o editorial que abordou especificamente o tema Religião (Confusões no Vaticano, com 2’13, no dia 15/08/12) ${ }^{77}$, somando-o ao resultado anterior, chega-se a um total de 12 ' 36 , equivalentes a $12,94 \%$ do noticiário informativo e a 11,66\% do noticiário total.

Entretanto, conforme explicado anteriormente, como a seção Editorial representa a opinião da Rádio Aparecida, emissora ligada à Igreja Católica, para efeito da análise a que se propõe este estudo, optou-se por levar em consideração o tempo total dos editoriais (10’40), somando-o ao das notícias sobre Religião (6’08) e às que apresentavam referências católicas (3’30), o que representou 23’16, ou 21,54\% do tempo total de noticiário em que pode ser observada a presença da Igreja Católica no Jornal Brasil Hoje (Gráfico 6).

${ }^{77}$ Ver nota 75 na página 82. 


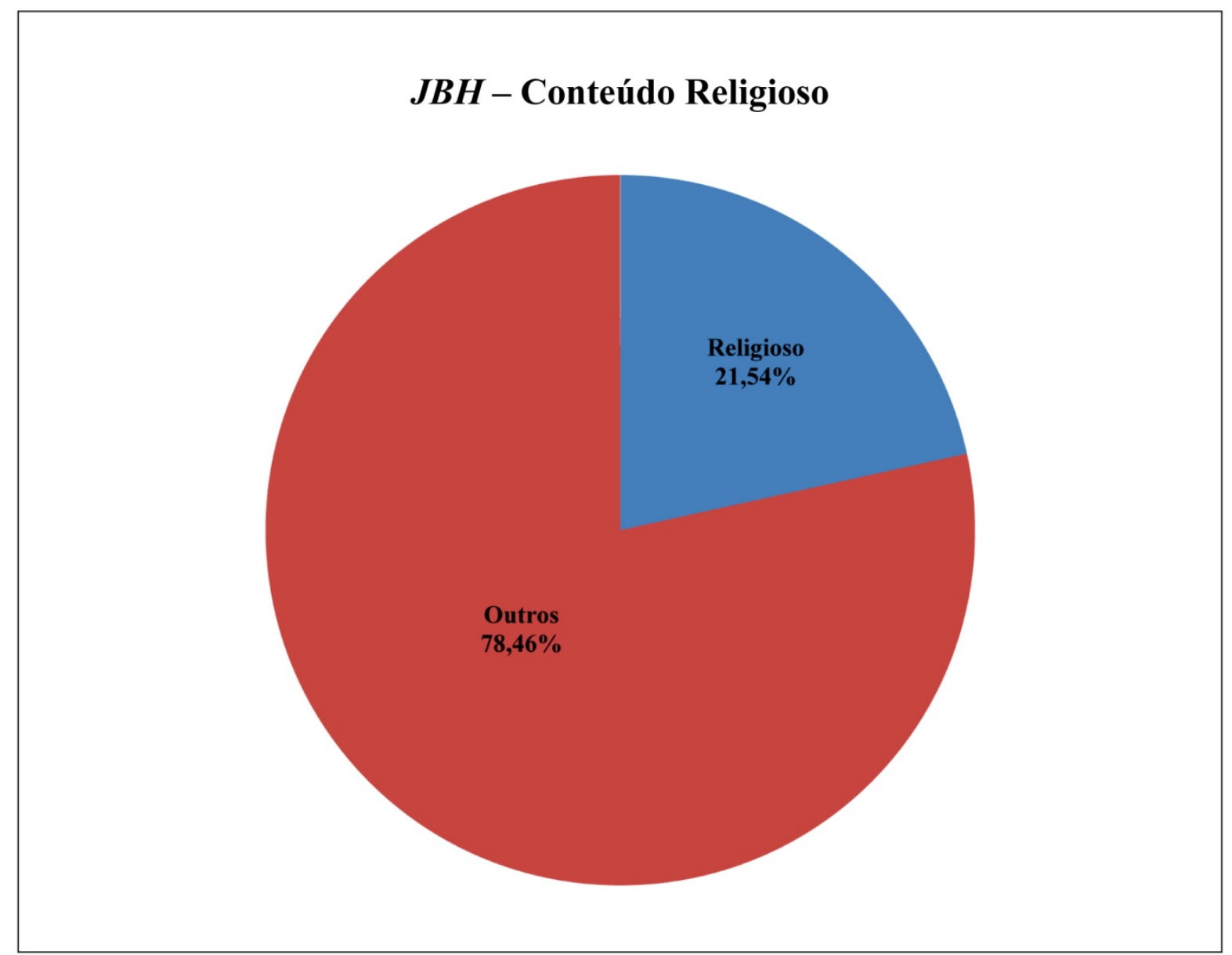

Gráfico 6: $\boldsymbol{J B H}$ - Conteúdo Religioso. Tempo total dos editoriais (10`40), mais o conteúdo de Religião (6’08), mais as notícias que apresentavam fontes católicas (3’30) representaram 23’16, ou 21,54\% do radiojornal. Tempo total da amostra: $1 \mathrm{~h} 49$.

A análise do Jornal Canção Nova $2^{a}$ Edição demonstrou que o noticiário esteve estruturado da seguinte forma (total de 1h49’17): Geral (27 notícias; representando 23,94\% ou 25’56 do radiojornal); Política (11; 20,54\% ou 22’15); Economia (19; 18,22\% ou 19’44); Religião (14; 14,49\% ou 15’42); Esporte (9; 13,99\% ou 15’09); Internacional (14; 7,72\% ou 8’22); e Institucional (2; 1,06\% ou 1’09), como pode ser visto no Gráfico 7. 


\section{Jornal Canção Nova $2^{a}$ Edição - Editorias}

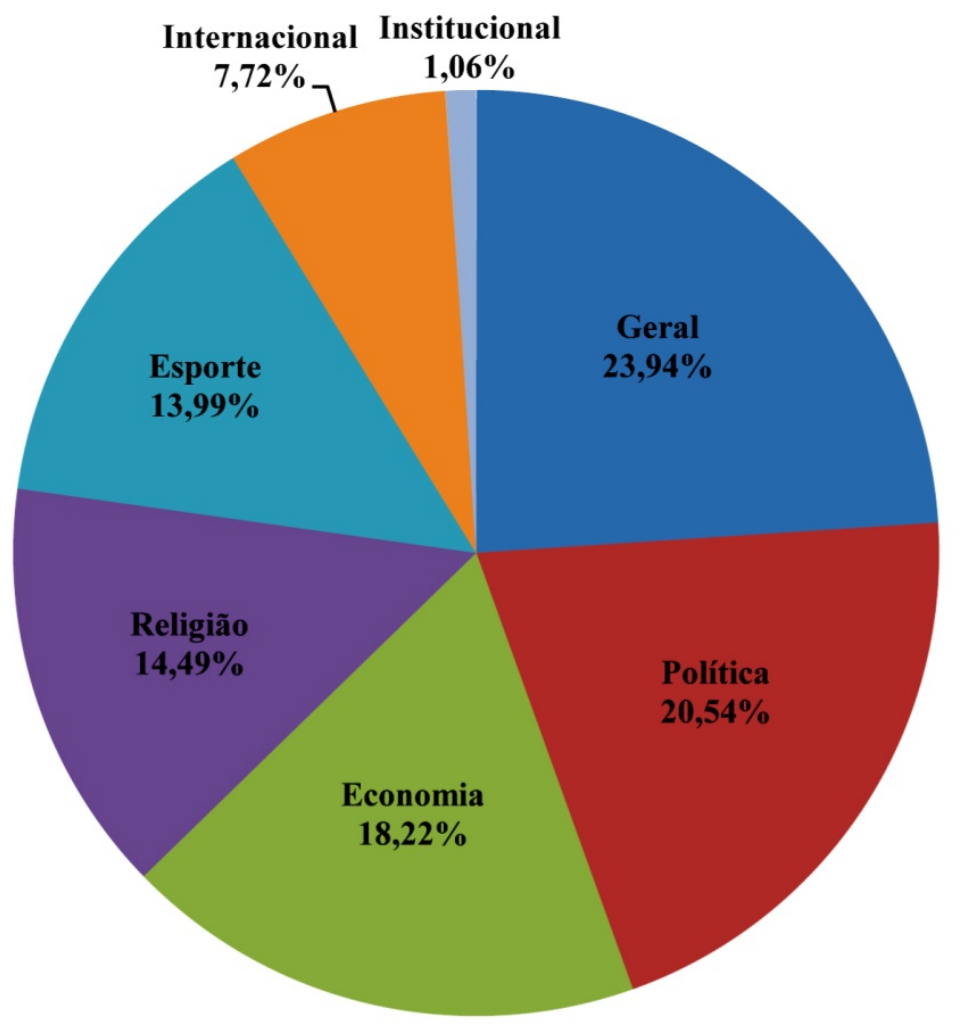

Gráfico 7: Jornal Canção Nova $2^{\boldsymbol{a}}$ Edição - Editorias. Total de 1h49'17. Geral: 27 notícias, 25'56. Política: 11 notícias, 22’15. Economia: 19 notícias, 19’44. Religião: 14 notícias, 15’42. Esporte: 9 notícias, 15’09. Internacional: 14 notícias, 8’22. E Institucional: 2 notícias, 1’09.

Foi detectada no radiojornal uma notícia utilizando fonte católica, no dia 31 de agosto de 2012, que integrava a editoria de Política ${ }^{78}$. O entrevistado era dom Raymundo Damasceno Assis, com sonora de 0`44. A notícia tinha um total de 1’42, ocupando 1,58\% do noticiário.

Dessa forma, somando-se as notícias sobre Religião (15’42) mais as notícias Institucionais encontradas no $J C N\left(1^{\prime} 09\right)^{79}$ com esta última (1’42), que apresentava fonte católica entrevistada, obtém-se um total de 18’34, o que corresponde a 17,14\% de tempo total

\footnotetext{
${ }^{78}$ Ver nota 74 , na página 81.

${ }^{79}$ Ver página 81.
} 
do radiojornal da Canção Nova com prevalência de referências católicas ou conteúdo religioso (Gráfico 8).

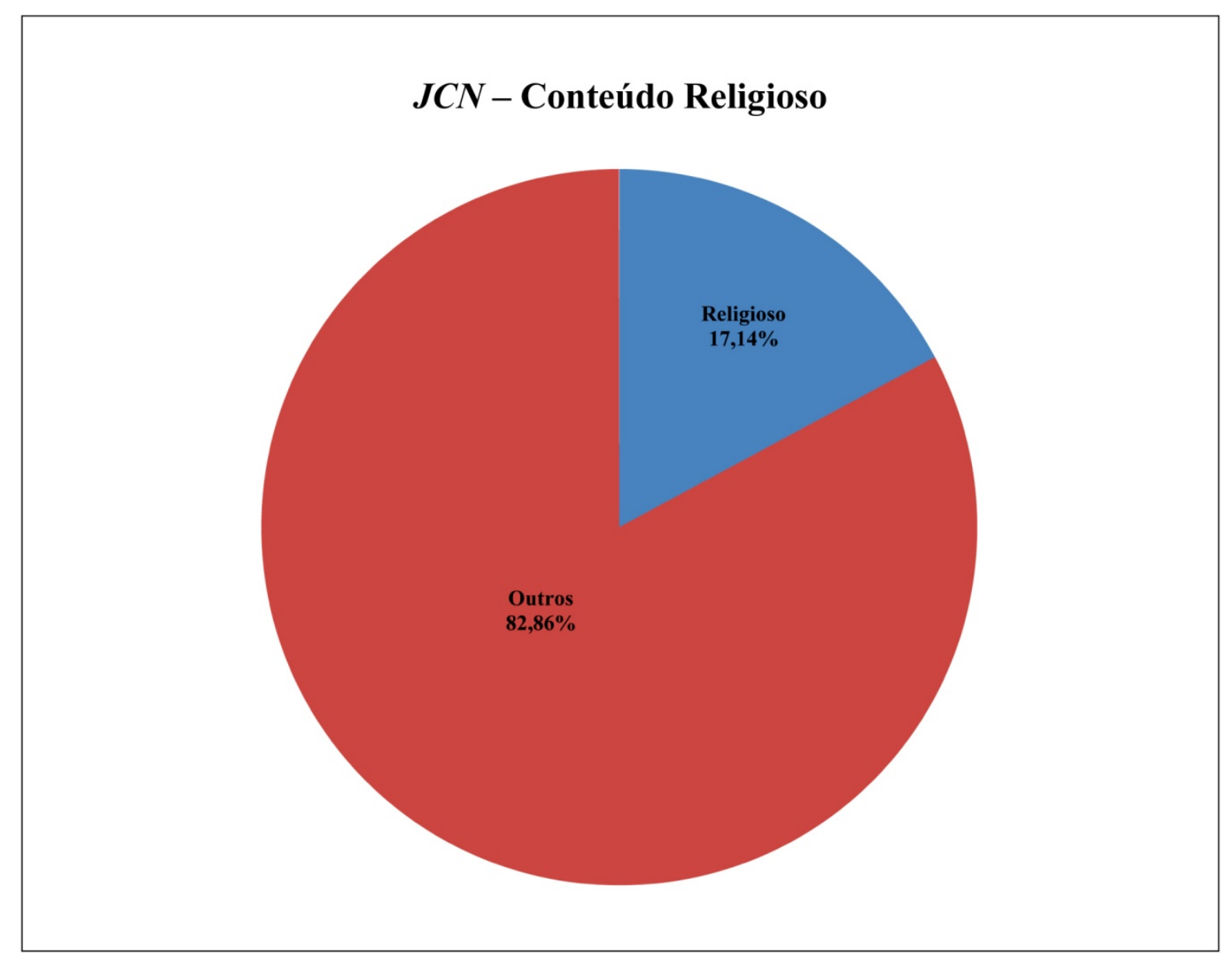

Gráfico 8: $\boldsymbol{J C N}$ - Conteúdo Religioso. Notícias sobre Religião (15'42), mais as Institucionais (1'09) e com fonte católica entrevistada (1’42) somaram 18’34. Tempo total de 1h49'17.

Essa análise posterior ao levantamento do percentual de editorias, considerando todas as notícias que tratavam de temas católicos (Religião), mais as que tinham referências católicas ou que promoviam a opinião da instituição (caso da seção Editorial do Jornal Brasil Hoje), assim como as notícias sobre ações e atividades de instituições católicas (agrupadas em Institucional, no caso do Jornal Canção Nova $2^{a}$ Edição), permitiu observar que o peso da presença da Igreja Católica foi maior na Rádio Aparecida (23’16”, ou 21,54\% do tempo total 
do $J B H$ ) do que na Rádio Canção Nova (18’34”, ou 17,14\% do $J C N$ ), com diferença percentual de $4,40 \%$, quando comparados os tempos dedicados ao tema nos dois radiojornais.

\subsection{Fontes entrevistadas nos radiojornais}

No Jornal Brasil Hoje, entre as fontes ouvidas, a que mereceu tempo maior foi dom Raymundo Damasceno Assis, arcebispo de Aparecida e presidente da Conferência Nacional dos Bispos do Brasil (CNBB), que falou por 4’30” ou 4,16 \% do total do radiojornal ${ }^{80}$.

Somando-se a participação de fontes eclesiais entrevistadas no $J B H$ (3 no total da amostra) - as de dom Raymundo Damasceno, mais a fala do núncio apostólico do Brasil, Dom Giovanni D’Aniello (0’27) e ainda a entrevista com o padre Edilberto Sena, diretor da Rádio Rural de Santarém $\left(0^{\prime} 45\right)^{81}$-, obtém-se um total de 5’42 de fontes religiosas entrevistadas que mereceram sonoras, o que representa 5,27\% do noticiário do $J B H$, conforme se verifica na Tabela 3.

\footnotetext{
${ }^{80}$ Dia 30/07/12, na editoria de Religião: O movimento foi intenso em Aparecida, nesse fim de semana (tempo total de 4’09 e sonora de 3’03); e dia 31/08/12, na editoria de Política: Presidente da CNBB diz que julgamento do mensalão deve servir de alerta aos políticos (tempo total de 1’31 e sonora de 1’27).

${ }^{81}$ Dia 30/07/12, na editoria de Religião: Arquidiocese do Rio de Janeiro recebe imagem da Nossa Senhora Aparecida para a Jornada Mundial da Juventude, no Rio, em 2013 (tempo total de 1’59 e sonora de 0’27).
} 


\begin{tabular}{|c|c|c|c|c|c|}
\hline Ordem & Fonte & Dia & Editoria & Tempo & Categoria \\
\hline 1 & $\begin{array}{c}\text { Dom Raymundo } \\
\text { Damasceno, presidente da } \\
\text { CNBB }\end{array}$ & $\begin{array}{l}30 / 07 / 12 \text { e } \\
31 / 08 / 12\end{array}$ & $\begin{array}{l}\text { Religião e } \\
\text { Política }\end{array}$ & 3’03 & Eclesial \\
\hline 2 & $\begin{array}{c}\text { Edvânia Kehrle, do } \\
\text { comando de greve da } \\
\text { FUNAI }\end{array}$ & 23/08/2012 & Geral & 1’28 & Sindical \\
\hline 3 & $\begin{array}{l}\text { João Furtado Neto, } \\
\text { secretário da Segurança } \\
\text { Pública de Goiás }\end{array}$ & 23/08/12 & Geral & 1’17 & Governamental \\
\hline 4 & $\begin{array}{c}\text { Josinaldo Barbosa, } \\
\text { presidente do Sindicato } \\
\text { dos Trabalhadores da } \\
\text { Educação do Estado de } \\
\text { Roraima }\end{array}$ & $31 / 08 / 2012$ & Geral & $0 ’ 56$ & Sindical \\
\hline 5 & $\begin{array}{c}\text { Padre Edilberto Sena, } \\
\text { diretor da Rádio Rural de } \\
\text { Santarém }\end{array}$ & $31 / 08 / 2012$ & Geral & $0 ` 45$ & Eclesial \\
\hline 6 & $\begin{array}{l}\text { Marcos Sá, representante } \\
\text { do Sindicato dos } \\
\text { Trabalhadores em Áreas } \\
\text { Indígenas de Roraima }\end{array}$ & 07/08/2012 & Geral & $0 ` 40$ & Sindical \\
\hline 7 & $\begin{array}{l}\text { Luciano Coutinho, } \\
\text { presidente do BNDES }\end{array}$ & 07/08/2012 & Economia & 0’34 & Governamental \\
\hline 7 & $\begin{array}{l}\text { Marcos Braga, presidente } \\
\text { da seção sindical dos } \\
\text { docentes da Universidade } \\
\text { Federal de Roraima }\end{array}$ & $31 / 08 / 2012$ & Geral & $0 ’ 34$ & Sindical \\
\hline 8 & $\begin{array}{l}\text { César Henrique Glud, } \\
\text { procurador do Trabalho } \\
\text { de Roraima } \\
\end{array}$ & 07/08/2012 & Geral & 0’33 & Judicial \\
\hline 9 & $\begin{array}{c}\text { Viviane Araújo, gerente } \\
\text { do Núcleo de Controle da } \\
\text { Hanseníase de Roraima }\end{array}$ & $15 / 08 / 2012$ & Geral & 0’31 & Governamental \\
\hline 10 & $\begin{array}{l}\text { Aloizio Mercadante, } \\
\text { ministro da Educação }\end{array}$ & $15 / 08 / 2012$ & Política & $0 ’ 30$ & Governamental \\
\hline 11 & $\begin{array}{l}\text { Marcelo Leonardo, } \\
\text { advogado de Marcos } \\
\text { Valério } \\
\end{array}$ & 07/08/2012 & Política & 0’29 & Governamental \\
\hline 12 & $\begin{array}{c}\text { Arnaldo Malheiros, } \\
\text { advogado de Delúbio } \\
\text { Soares } \\
\end{array}$ & 07/08/2012 & Política & 0’28 & Especialista \\
\hline 13 & $\begin{array}{c}\text { Dom Giovanni D’Aniello, } \\
\text { núncio apostólico do } \\
\text { Brasil }\end{array}$ & $30 / 07 / 2012$ & Religião & $0 ’ 27$ & Eclesial \\
\hline 13 & $\begin{array}{c}\text { Fábio Comparato, } \\
\text { advogado da Família de } \\
\text { Maria Amélia Teles }\end{array}$ & $15 / 08 / 2012$ & Geral & $0 ’ 27$ & Especialista \\
\hline 14 & $\begin{array}{l}\text { Margareth Capurro, } \\
\text { professora da USP }\end{array}$ & 07/08/2012 & Geral & $0 ’ 25$ & Especialista \\
\hline
\end{tabular}




\begin{tabular}{|c|c|c|c|c|c|}
\hline 15 & $\begin{array}{c}\text { Cláudio Fontelles, } \\
\text { membro da Comissão da } \\
\text { Verdade }\end{array}$ & 31/08/2012 & Política & $0 ’ 24$ & Especialista \\
\hline 16 & $\begin{array}{l}\text { Valdir Valter, presidente } \\
\text { da União das Associações } \\
\text { de Bairros de Roraima }\end{array}$ & 15/08/2012 & Geral & $0 ’ 23$ & Independente \\
\hline 17 & $\begin{array}{c}\text { Fábio Gaudenzi, diretor } \\
\text { da Vigilância } \\
\text { Epidemiológica de Santa } \\
\text { Catarina }\end{array}$ & 15/08/2012 & Geral & $0 ’ 22$ & Governamental \\
\hline 18 & $\begin{array}{c}\text { Marcia Carvalho, } \\
\text { coordenadora de Doenças } \\
\text { Transmissíveis do } \\
\text { Ministério da Saúde }\end{array}$ & $15 / 08 / 2012$ & Geral & $0 ’ 21$ & Governamental \\
\hline 19 & $\begin{array}{c}\text { Matilde Lemes dos } \\
\text { Santos, diretora de } \\
\text { Educação para o Trânsito } \\
\text { da Agência Municipal de } \\
\text { Trânsito de Goiânia }\end{array}$ & 07/08/2012 & Geral & $0 ’ 20$ & Governamental \\
\hline 19 & $\begin{array}{c}\text { Eneida Guimarães, } \\
\text { anistiada do período da } \\
\text { ditadura } \\
\end{array}$ & 31/08/2012 & Geral & $0 ’ 20$ & Protagonista \\
\hline 20 & $\begin{array}{c}\text { Roberto Kalil Filho, } \\
\text { médico do ex-presidente } \\
\text { Lula } \\
\end{array}$ & 07/08/2012 & Política & 0’18 & Especialista \\
\hline 20 & $\begin{array}{c}\text { Milton Azevedo, vice- } \\
\text { presidente da Associação } \\
\text { Brasileira de } \\
\text { Infraestrutura }\end{array}$ & 23/08/2012 & Geral & 0’18 & Empresarial \\
\hline 21 & $\begin{array}{c}\text { Geraldo Alckmin, } \\
\text { governador de São Paulo }\end{array}$ & 07/08/2012 & Economia & $0 ’ 17$ & Governamental \\
\hline 21 & $\begin{array}{c}\text { José Luís dos Santos, } \\
\text { presidente da Associação } \\
\text { Brasileira de Agências de } \\
\text { Regulação }\end{array}$ & 23/08/2012 & Economia & 0’17 & Empresarial \\
\hline 22 & $\begin{array}{l}\text { Roberto Gurgel, } \\
\text { procurador-geral da } \\
\text { República } \\
\end{array}$ & 07/08/2012 & Política & $0 ’ 14$ & Judicial \\
\hline 23 & $\begin{array}{c}\text { Paulo Sérgio Pinheiro, } \\
\text { presidente da Comissão } \\
\text { da Verdade }\end{array}$ & 07/08/2012 & Política & $0 ’ 12$ & Especialista \\
\hline 24 & $\begin{array}{l}\text { Guido Mantega, ministro } \\
\text { da Fazenda }\end{array}$ & 07/08/2012 & Economia & $0 ’ 12$ & Governamental \\
\hline 25 & $\begin{array}{c}\text { José Luís Oliveira, } \\
\text { advogado de José Dirceu }\end{array}$ & 07/08/2012 & Política & 0’05 & Especialista \\
\hline
\end{tabular}

Tabela 2: Jornal Brasil Hoje - Fontes entrevistadas em ordem de tempo ocupado no noticiário. 
No Jornal Canção Nova $2^{a}$ Edição, a fonte entrevistada que por mais tempo falou foi o ministro da Educação, Aloizio Mercadante, com uma sonora de 1’11, ou 1,09\% do total do radiojornal $^{82}$. Em relação às fontes eclesiais (2 no total da amostra), a que mereceu mais tempo foi o papa Bento XVI ${ }^{83}$, seguida por Dom Raymundo Damasceno Assis ${ }^{84}$. Somando-se as sonoras do papa (1’04 ou 0,98\% do total do noticiário) à de dom Raymundo Damasceno (0’44, ou 0,67\%), obtém-se um total de 1’48 (1,65\% de tempo de noticiário) de entrevistas de fontes eclesiais no jornal da Rádio Canção Nova, como pode ser verificado na Tabela 3.

\begin{tabular}{|c|c|c|c|c|c|}
\hline Ordem & Fonte & Dia & Editoria & Tempo & Categoria \\
\hline 1 & $\begin{array}{l}\text { Aloizio Mercadante, } \\
\text { ministro da Educação }\end{array}$ & $15 / 08 / 2012$ & Política & 1’11 & Governamental \\
\hline 2 & $\begin{array}{c}\text { Ricardo Lewandowski, } \\
\text { ministro do Supremo } \\
\text { Tribunal Federal }\end{array}$ & 23/08/2012 & Política & 1’09 & Judicial \\
\hline 3 & $\begin{array}{c}\text { Saulo Abreu, } \\
\text { Secretário de Estado de } \\
\text { Logística e Transportes } \\
\text { de São Paulo }\end{array}$ & $15 / 08 / 2012$ & Geral & 1’05 & Governamental \\
\hline 4 & Papa Bento XVI & $\begin{array}{c}30 / 07 / 12 \mathrm{e} \\
15 / 08 / 12\end{array}$ & Religião & 1’04 & Eclesial \\
\hline 5 & $\begin{array}{c}\text { Dom Raymundo } \\
\text { Damasceno Assis, } \\
\text { presidente da CNBB }\end{array}$ & $31 / 08 / 2012$ & Religião & $0 ’ 44$ & Eclesial \\
\hline 6 & $\begin{array}{c}\text { José Luís de Oliveira, } \\
\text { advogado de José } \\
\text { Dirceu }\end{array}$ & 07/08/2012 & Política & $0 ’ 37$ & Especialista \\
\hline 7 & $\begin{array}{l}\text { Wagner Love, jogador } \\
\text { do Flamengo }\end{array}$ & 31/08/2012 & Esporte & $0 ’ 25$ & Protagonista \\
\hline 8 & $\begin{array}{l}\text { Miriam Belchior, } \\
\text { ministra do } \\
\text { Planejamento }\end{array}$ & 31/08/2012 & Economia & $0 ’ 24$ & Governamental \\
\hline 9 & $\begin{array}{c}\text { Guido Mantega, } \\
\text { ministro da Fazenda }\end{array}$ & $31 / 08 / 2012$ & Economia & 0’17 & Governamental \\
\hline
\end{tabular}

\footnotetext{
${ }^{82}$ No dia 15/08/12, entrando na editoria de Política: IDEB 2011 revela avanço na educação básica, mas ensino médio preocupa (tempo total de 3’12 e sonora de 1’11).

${ }^{83}$ Dia 30/07/12, na editoria de Religião: Papa assegura que Eucaristia é encontro do homem com Deus (tempo total de 1'49 e sonora de 0’30); e, no dia 15/08/12, novamente na editoria de Religião: Na oração mariana do Angelus, papa afirma que assunção nos indica o futuro da humanidade (tempo total de 2'11 e sonora de 0’34).

${ }^{84}$ Dia 31/08/12, na editoria de Política: O STF condena João Paulo Cunha, Pizzolato e Valério, e conclui primeira parte do mensalão (tempo total de 1'43, sonora de 0’44).
} 


\begin{tabular}{|c|c|c|c|c|c|}
\hline 10 & $\begin{array}{l}\text { Renato, jogador do } \\
\text { Botafogo }\end{array}$ & 31/08/2012 & Esporte & $0 ’ 14$ & Protagonista \\
\hline 11 & $\begin{array}{l}\text { Luís Fabiano, jogador } \\
\text { do São Paulo }\end{array}$ & $31 / 08 / 2012$ & Esporte & $0 ’ 12$ & Protagonista \\
\hline 11 & $\begin{array}{l}\text { Álvaro Dias, líder do } \\
\text { PSDB }\end{array}$ & $31 / 08 / 2012$ & Política & $0 ’ 12$ & Legislativa \\
\hline 12 & $\begin{array}{l}\text { Advogado de Delúbio } \\
\text { Soares (nome não } \\
\text { citado) }\end{array}$ & 07/08/12 & Política & $0 ’ 11$ & Especialista \\
\hline 12 & Dilma Rousseff & $31 / 08 / 2012$ & Política & 0’11 & Governamental \\
\hline 12 & $\begin{array}{c}\text { José Sarney, presidente } \\
\text { do Senado }\end{array}$ & $31 / 08 / 2012$ & Política & $0 ’ 11$ & Legislativa \\
\hline 13 & $\begin{array}{c}\text { Fernando Pacheco, } \\
\text { advogado de José } \\
\text { Genoino }\end{array}$ & 07/08/12 & Política & 0’08 & Especialista \\
\hline 13 & $\begin{array}{c}\text { Robson Andrade, } \\
\text { presidente da } \\
\text { Confederação Nacional } \\
\text { da Indústria }\end{array}$ & $31 / 08 / 2012$ & Economia & $0 ’ 08$ & Empresarial \\
\hline
\end{tabular}

Tabela 3: Jornal Canção Nova - Fontes entrevistadas em ordem de tempo ocupado no noticiário.

A seguir, passou-se à classificação das fontes entrevistadas por categorias em cada um dos radiojornais. No Jornal Brasil Hoje, as fontes que mereceram maior tempo de entrevista foram as eclesiais: 3 fontes totalizando 5’ 42 , o que representou $29,71 \%$ do tempo total de entrevistas (19’11) ou 5,27\% do radiojornal. Em seguida, estavam as fontes governamentais: 10, com um tempo de 4'24, o que representa $22,93 \%$ do total de entrevistas ou $4,07 \%$ do radiojornal. A seguir, vieram as fontes sindicais: 4, com 4’11, representando 21,80\% do total de entrevistas e 3,87\% do tempo de radiojornal. Os especialistas (7) mereceram um total de 1'49 de sonoras, representando 14,68\% do tempo total de entrevistas ou 2,60\% de radiojornal. As fontes judiciais (2) totalizaram 0 ' 47 , ou $4,08 \%$ do tempo de entrevistas e $0,72 \%$ de radiojornal. As fontes empresariais (2), em seguida, ocuparam 0’35 de tempo de sonoras, $3,04 \%$ das entrevistas e $0,54 \%$ de radiojornal. As fontes independentes (1) seguiram, com 0’23, 1,99\% e 0,35\%, respectivamente. Por fim os protagonistas (1), mereceram somente 0’20 de sonora, representando $1,73 \%$ do total de entrevistas e $0,30 \%$ de radiojornal, conforme se verifica no Gráfico 9. 


\section{Jornal Brasil Hoje - Fontes Entrevistadas}

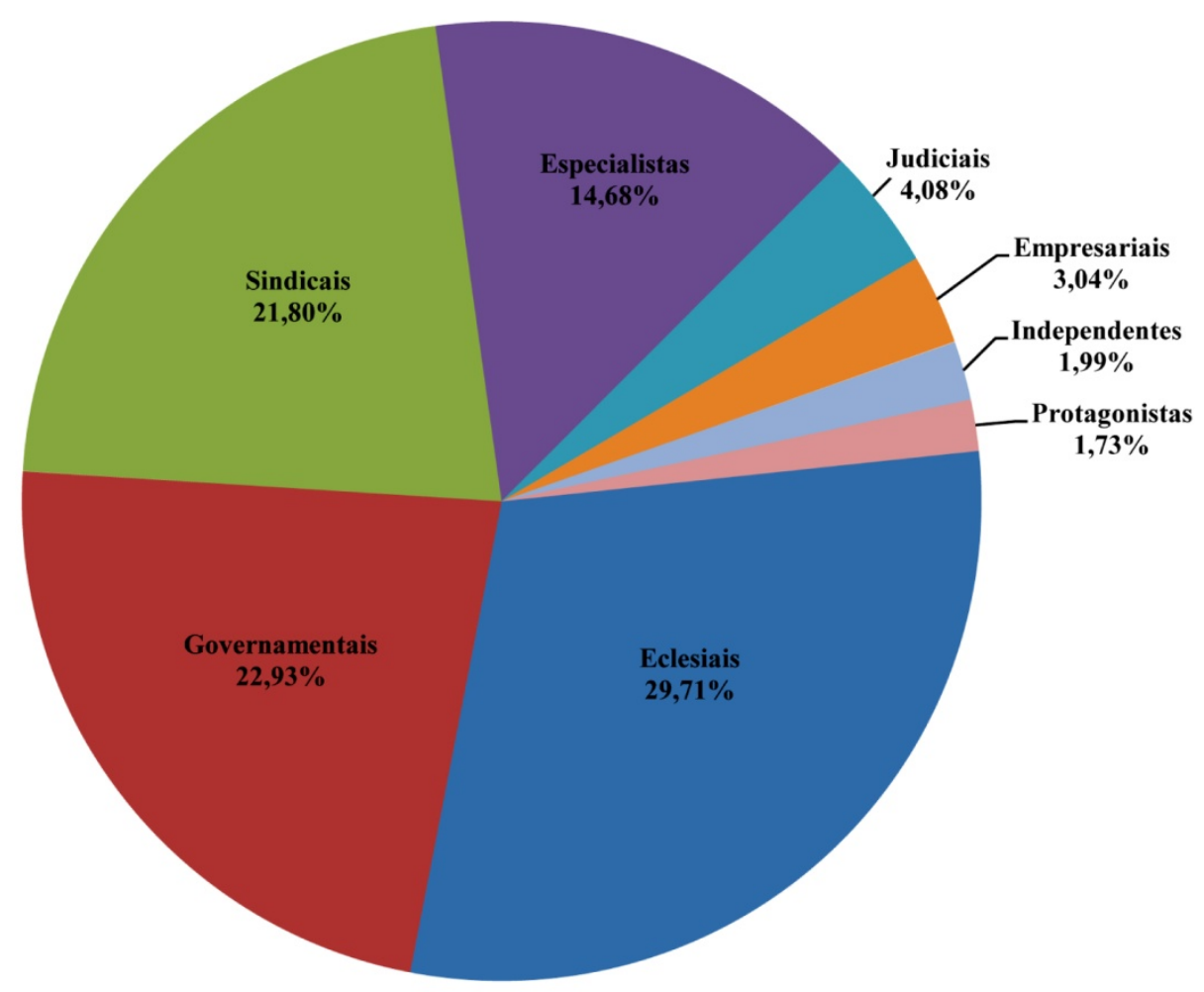

Gráfico 9: $\boldsymbol{J} \boldsymbol{B H}$ - Fontes Entrevistadas. Tempo total de entrevistas: 19'11. Fontes eclesiais: 3 notícias, com 5'42. Fontes governamentais: 10 notícias, com 4'24. Sindicais: 4 notícias, com 4'11. Especialistas: 7 notícias, com 1'49. Judiciais: 2 notícias, com 0’47. Empresariais: 2 notícias, com 0’35. Independentes: 1 notícia, com 0’23. E Protagonistas: 1 notícia, com 0’20.

Já o Jornal Canção Nova $2^{a}$ Edição apresentou a seguinte distribuição de fontes entrevistadas: governamentais (5 na amostra analisada), com total de 3’08 de entrevistas, o que representou $35 \%$ do tempo total de sonoras (8’57) e 2,89\% do radiojornal; eclesiais (2), totalizando 2'22, com percentual de $26,44 \%$ do total de entrevistas e 2,10\% do radiojornal; judiciais (1), com tempo de 1'09, representando 12,84\% do tempo de entrevistas e 1,06\% de radiojornal; especialistas (3), com 0’56, representando 10,42\% do total de entrevistas ou 0,86\% do radiojornal; protagonistas (3), com 0’51, 9,42\% das entrevistas e 0,78\% de radiojornal; legislativas (2), 0’23, 4,20\% das entrevistas e 0,35\% do radiojornal; e, por fim, as 
fontes empresariais (1), com 0’08 de tempo, $1,48 \%$ ou $0,12 \%$ das entrevistas e de radiojornal, respectivamente (Gráfico 10).

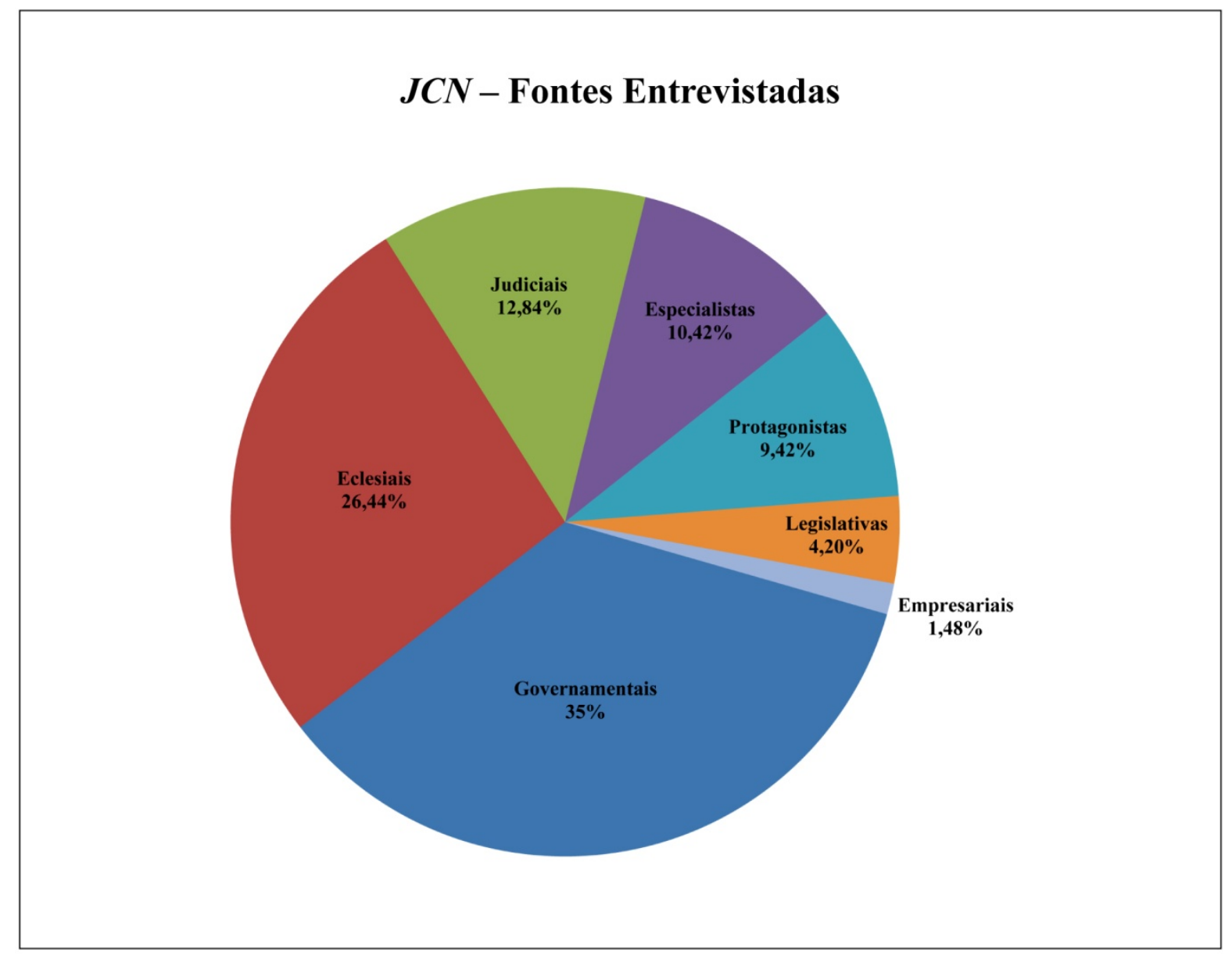

Gráfico 10: $\boldsymbol{J C N}$-Fontes Entrevistadas. Tempo total de sonoras (8'57). Fontes governamentais: 5, com total de 3'08. Eclesiais: 2, com 2'22. Judiciais: 1, com 1'09. Especialistas: 3, com 0'56. Protagonistas: 3, com 0'51. Legislativas: 2, com 0’23. E Empresariais: 1, com 0’08 de tempo.

Para concluir essa etapa, observou-se que, no $J B H$, o tempo total de entrevistas, de 19'11, representou 17,76\% do total do radiojornal, como pode ser visto no Gráfico 11. 


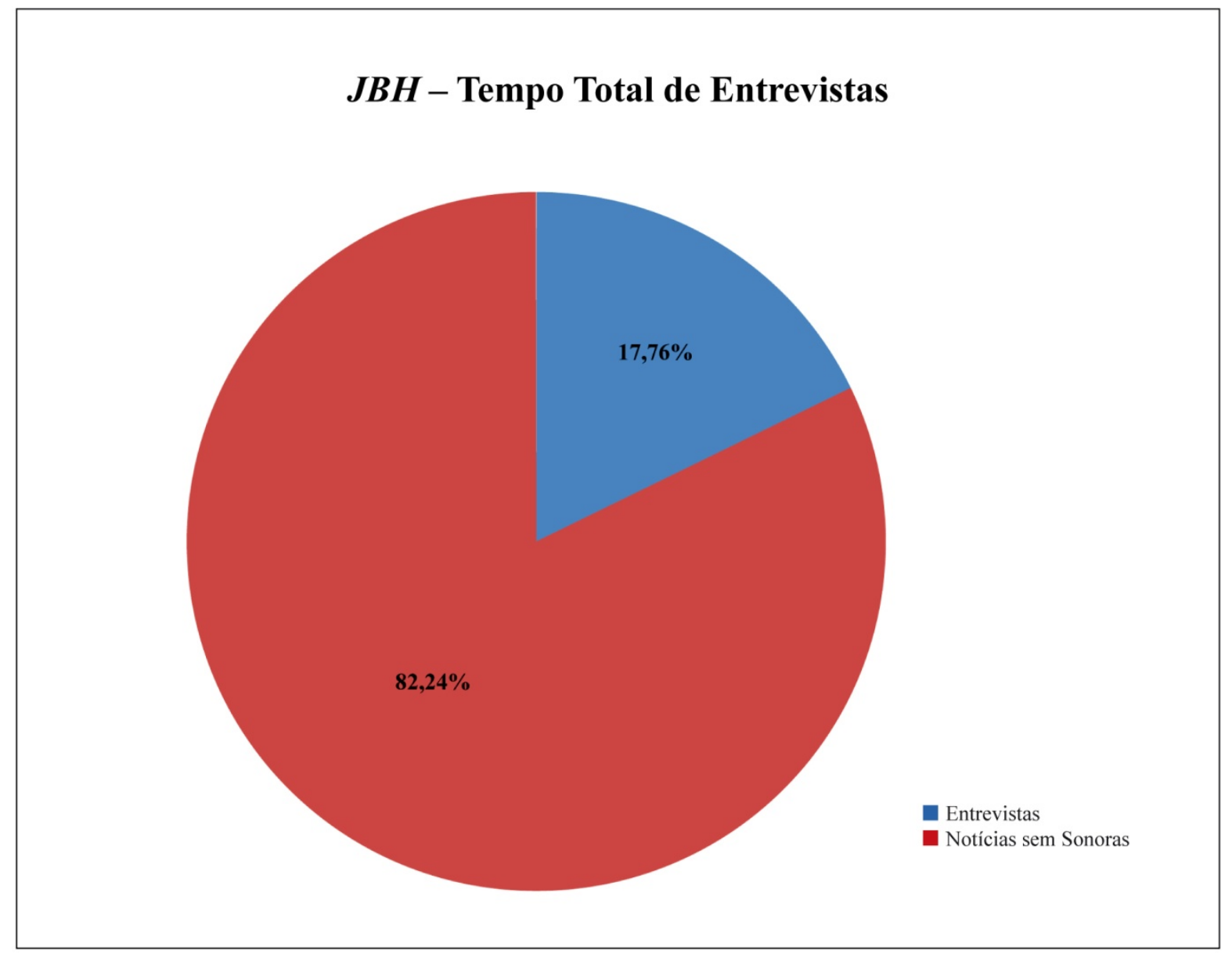

Gráfico 11: $\boldsymbol{J} \boldsymbol{B H}$ - Tempo Total de Entrevistas. O tempo total de entrevistas foi $19{ }^{\prime} 11$ ou 17,78\% do radiojornal.

Já no JCN, o tempo de entrevistas total de entrevistas (8’57) representou 8,26\% do radiojornal, como é demonstrado no Gráfico 12. 


\section{$J C N$ - Tempo Total de Entrevistas}

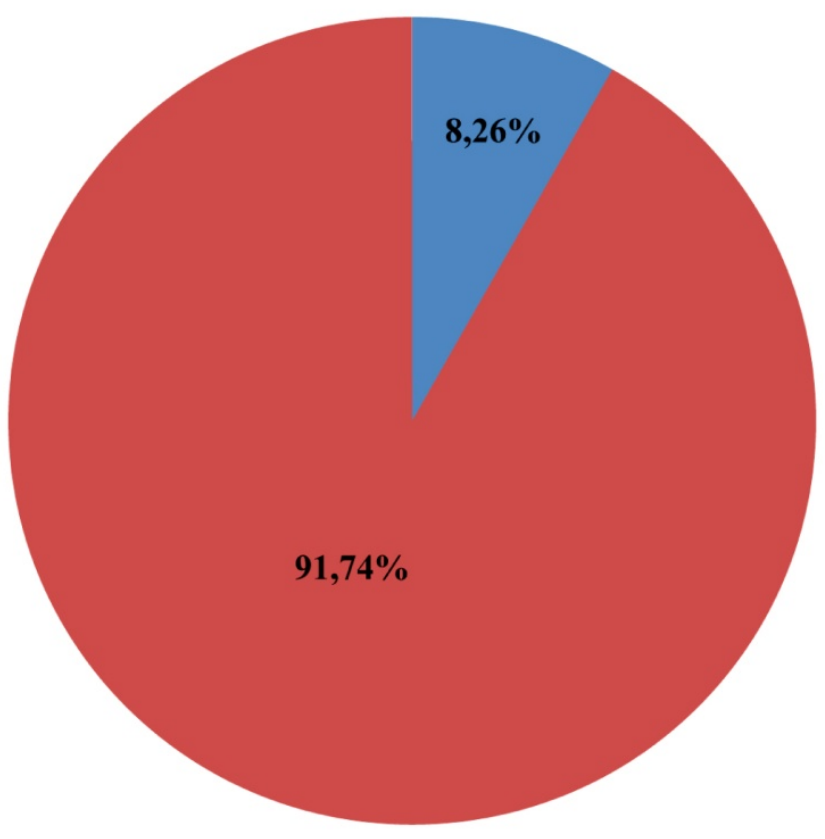

Gráfico 12: $\boldsymbol{J C N}$ - Tempo Total de Entrevistas. O tempo de entrevistas total foi de 8'57, representando $8,26 \%$ do radiojornal.

\subsection{Temas de interesse católico nos radiojornais}

Dentre as "Perspectivas de Ação" estabelecidas pela Conferência Nacional dos Bispos do Brasil (CNBB) no documento Diretrizes para a Ação Evangelizadora da Igreja no Brasil: 2011-2015, lançado pela entidade em 2011, após a Assembleia Geral realizada em Aparecida (SP), em maio de 2011, a CNBB estabeleceu algumas linhas de atuação agrupadas segundo o que considera "urgências na ação evangelizadora” (ver Capítulo 2, pp. 47-48). Em relação a uma das "urgências” apontadas, "Igreja a serviço da vida plena para todos”, o documento sugere ações que se refiram à defesa do valor da vida e à sua promoção "em todas as suas expressões” (CNBB, 2011, p.83). 
Nesse sentido, a entidade reafirma ser necessário, entre outras formas de atuação, que a Igreja Católica e seus membros e representantes acompanhem "as alegrias e preocupações” dos trabalhadores e trabalhadoras, dediquem especial atenção na luta contra o desemprego, subemprego e exploração pelos métodos de terceirização, deem atenção especial aos migrantes, vítimas do tráfico, de preconceito e discriminação, seja por sua etnia, cultura, expressão religiosa ou condição social - como povos indígenas, de origem africana ou latinoamericana e população carcerária (Ibidem, pp. 85-86).

O documento convoca, ainda, a Igreja e seus representantes a estarem sempre atentos para a defesa dos direitos humanos e a empenharem-se na busca de políticas públicas que “ofereçam as condições necessárias ao bem-estar de pessoas, famílias e povos” (Ibid., p. 87). Outros importantes campos de ação, acrescenta a CNBB no documento, são a educação "para a preservação da natureza e o cuidado com a ecologia, através de atitudes que respeitem a biodiversidade e de ações que zelem pelo meio ambiente” (Ibid., p. 87).

Tal agenda reafirma valores pelos quais a Igreja vem optando de forma cada vez mais explícita desde o Concílio Vaticano II e incorpora preocupações mais atuais, como a defesa da ecologia e a preservação do meio ambiente. Expressas em documentos oficiais da Santa Sé, do Celam e da CNBB ao longo dos últimos 50 anos, essas propostas de atuação são também defendidas e adotadas pelos profissionais de comunicação católica entrevistados para esta pesquisa.

Segundo o padre César Moreira, diretor-geral da Rádio e TV Aparecida (APÊNDICE A), a linha editorial da rádio procura "valorizar o humano, defender tudo o que é humano, porque é a forma de chegar ao divino”. E o jornalismo da rádio, segundo o diretor, atua nessa direção: "Defender os valores humanos, colocar o sujeito de pé, brigar as brigas que ele precisa, lutar pelos interesses, pelos direitos que ele tem”. Entre os temas preferenciais no trabalho de seleção das notícias que compõem o noticiário da rádio, segundo seu diretor, estão as que se referem às “teses” que a Igreja defende: “As questões dos movimentos, a questão da terra, das pastorais, do índio. (...) O que nos interessa é mais de fundo social”, enfatiza.

Ederson Santos, editor-chefe de Jornalismo da Rádio Aparecida, reafirma essa opção por temas de interesse social incorporados ao noticiário, frisando sempre que a emissora evita preferencialmente as notícias sobre violência ou que possam conter algum grau de 
sensacionalismo. "Nós somos assumidamente uma emissora católica. Então, tem algumas coisas que a gente não coloca. Por exemplo, não damos espaço para a violência” (APÊNDICE B). O editor explicita, ainda, que a missão do jornalismo da emissora, além da de "valorizar o ser humano”, é despertar os ouvintes para a cidadania. “A gente quer educar as pessoas para a cidadania”, afirma Santos.

Catarina Jatobá, editora do Jornal Canção Nova $2^{a}$ Edição, da Rádio Canção Nova AM, explica que o objetivo do jornalismo produzido pela emissora "é o de deixar o (...) ouvinte informado, porque a gente sabe que tem pessoas que ouvem a Canção Nova o tempo inteiro”. Para a editora, a principal missão do noticiário da rádio é “informar, conscientizar, sempre primando pelo nosso perfil editorial, que é ‘um jornalismo a serviço da vida e da esperança'”’. Entre os temas citados pela editora como sendo de interesse da rádio estão notícias de Política, Economia, Igreja, Saúde, Meios de Transporte, Tecnologia. “Tudo isso para a gente formar o cidadão por completo, para deixar o nosso ouvinte informado de todas as coisas, de todas as áreas (APÊNDICE D)”, afirma.

A editora acrescenta que a rádio também evita selecionar notícias que possam estar relacionadas a “escândalos” ou violência. “Quando é uma coisa que é realmente necessária, a gente vai apurar os fatos, para primar pela pessoa, pela dignidade da pessoa”, diz. Ainda, segundo Catarina, a rádio procura evangelizar "no sentido também de apresentar ao público, ao ouvinte, aquilo que ele pode fazer de bom”.

A gente precisa estar informada, saber o que se passa no mundo, não ser um cristão alienado, porque essa não é a nossa proposta: de que as pessoas fiquem ali rezando o tempo inteiro, sem saber da necessidade de quem está do lado. Então, é informar, conscientizar, sempre primando pelo nosso perfil editorial, que é "um jornalismo a serviço da vida e da esperança”.

O jornalista, radialista e apresentador do Jornal Canção Nova $2^{a}$ Edição, Reinaldo César (APÊNDICE E), também destaca algumas posições que, em sua opinião, a Rádio Canção Nova deve assumir em relação ao jornalismo. 
O jornalismo tem que ser feito voltado para os interesses da sociedade, o interesse do bem comum, das pessoas, fazer a diferença, levar esperança, não ficar reclamando da vida, mas apontar caminhos, não no sentido de um jornalismo denuncista, mas que mostra caminhos que levem as pessoas a um grau de esperança, porque, sem esperança ninguém vai a lugar nenhum.

Para o apresentador, a emissora procura fazer um jornalismo "voltado para a sociedade, informando, formando, levando alegria e a ‘boa nova'. E lutando também por justiça”.

Dom Dimas Lara Barbosa, presidente da Comissão Episcopal Pastoral para a Comunicação da Conferência Nacional dos Bispos do Brasil (CNBB), em entrevista à autora (APÊNDICE H), cita "as lutas e movimentos sociais, a defesa da dignidade da pessoa e dos direitos humanos" como temas prioritários de um jornalismo evangelizador ou católico, sobretudo guiado "pela ética, verdade e respeito também ao contraditório", ressalta.

Partindo desses conceitos e definições, foi possível observar uma série de temas de interesse presentes na amostra dos radiojornais analisados, que podem ser considerados característicos do noticiário das emissoras católicas, para além das notícias sobre a Igreja Católica propriamente ditas. A proposta foi a de identificar as notícias que pudessem representar a seleção de temas de interesse social e humano conforme citados pelos entrevistados e evidenciados em documentos oficiais da Igreja, como as mais recentes diretrizes da CNBB. A seleção dos temas representa uma tentativa de caracterizar o que possa ser definido como tema próprio do jornalismo evangelizador ou do jornalismo católico. O recorte escolhido não inclui as notícias que entraram na editoria Religião.

Dessa forma, para efeito desta análise, procurou-se observar, na amostra escolhida de cinco edições de cada um dos radiojornais, notícias relacionadas a questões como direitos humanos, promoção da vida e formação dos ouvintes, a fim de obterem-se subsídios para compor o diferencial do jornalismo praticado nessas duas emissoras, segundo as definições expressadas pelos profissionais que nelas trabalham e por representantes da Igreja entrevistados, ao refletirem sobre as características do jornalismo "católico". A partir da observação das notícias dentro da amostra, procurou-se selecionar notícias sobre temas que pudessem ser identificados como sendo de interesse desse segmento. Como resultado dessa observação das amostras analisadas, foram identificados nove temas principais distribuídos 
pelos dois radiojornais: Direitos Humanos, Saúde, Educação, Greves, Indígenas, Segurança, Manifestações de Trabalhadores, Negociações Sindicais e Meio Ambiente.

No caso da Rádio Aparecida, foram encontradas notícias sobre tais temas, tanto no noticiário informativo quanto opinativo, nas editorias de Geral (terceiro bloco do radiojornal), Política (primeiro bloco) e Editorial (terceiro bloco). Essas estão distribuídas percentualmente conforme exposto a seguir.

No $J B H$, em relação ao tempo total de noticiário (1h49'), as notícias sobre Greves ${ }^{85}$ (6) ocuparam o primeiro lugar em tempo, entre os temas analisados: 9'49, o que representou 9,08\% do tempo total de radiojornal. Em segundo lugar, estavam notícias sobre Saúde (6; 6’22 ou 5,89\% do tempo total de radiojornal) ${ }^{86}$. A seguir, em terceiro, as notícias sobre Direitos Humanos (3; 5’11 ou 4,79\% do radiojornal) ${ }^{87}$, seguidas, em quarto, por Educação (2; 4’02 ou 3,73\%) ${ }^{88}$ e, em quinto, notícias relacionadas aos movimentos de populações Indígenas (3, 2’54 ou 2,68\%) ${ }^{89}$. Em sexto lugar, vem o editorial do dia 31/8/2012, sobre o

${ }^{85}$ No dia 15/08/2012: Federação do Comércio do Estado de São Paulo cobrou o fim das greves que estão em andamento (0’52) na editoria de Geral. No dia 23/08/2012: Confederação de Servidores Federais vai ao Supremo contra corte de ponto $(0,45)$ em Política; Servidores efetivos da FUNAI realizaram manifestação contra o corte de ponto dos servidores em greve (1'28) e Em Goiás, secretário de Segurança Pública do Estado manda cortar pontos de agentes e escrivães da Polícia Civil, em greve há 43 dias (1’17), ambas em Geral. E, no dia 31/08/20112, Professores da Universidade Federal de Roraima resolvem manter a paralisação de aulas por tempo indeterminado ( 2'15) e Agentes da Polícia Federal continuam em greve por tempo indeterminado (0’29), ambas em Geral.

86 No dia 07/08/2012: Governo vai lançar programa Brasil Sorridente (0’31) e Projeto experimental cria mosquitos da dengue transgênicos para combater a doença (1’30), ambas em Geral. No dia 15/08/2012: Metade das mortes por gripe A em Santa Catarina está relacionada ao tratamento tardio (3’02), Secretaria de Saúde realiza oficina para definir campanha de combate à hanseníase, em Roraima (1'17) e Número de vítimas de dengue sofreu uma queda no Espírito Santo (0’55), todas em Geral. No dia 23/08/2012, Região de Açailândia, no Maranhão, realizou operação que fechou fábricas clandestinas de queijo e apreendeu quatro toneladas do produto (0’39), em Geral.

${ }^{87}$ No dia 30/07/2012, Conselho Nacional de Política Criminal e Penitenciária recebe, até dia 2 de agosto, sugestões para definir o perfil de detentos que serão beneficiados pelo indulto de Natal deste ano (0'56), em Geral. No dia 15/08/2012, Coronel Carlos Alberto Ustra é acusado pela Justiça por responsabilidade de tortura durante o período do regime militar (1’54), em Geral. E, no dia 31/8/2012, Belém é a quarta capital a receber a Comissão Nacional da Verdade (2’21), em Política.

${ }^{88}$ No dia 15/08/2012, Ministro da Educação, Aloízio Mercadante, diz que o Brasil ainda está longe de conseguir boa nota na educação básica (2’29) e Índice do Ministério da Educação registra melhora na qualidade do ensino fundamental (1’33) ambas em Política.

${ }^{89}$ No dia 30/07/2012, Mais de 14 mil maranhenses declaradamente índios estão aptos a votar nas eleições municipais, programadas para outubro (0’23) em Geral. No dia 15/8/2012, Justiça determina paralisação nas obras de Belo Monte (0’27) em Geral. E no dia 31/08/2012, Indígenas e movimentos sociais se unem para pedir ao governo paralisação de obras em hidrelétricas no Pará (2’04), em Geral. 
tema Meio Ambiente (1, 2’29 ou 2,29\%) ${ }^{90}$. E, por fim, em sétimo, uma notícia abordando o tema Segurança (1, 0’28 ou 0,43\%) ${ }^{91}$, como é mostrado no Gráfico 13.

\section{$J B H$ - Temas de Interesse Católico}
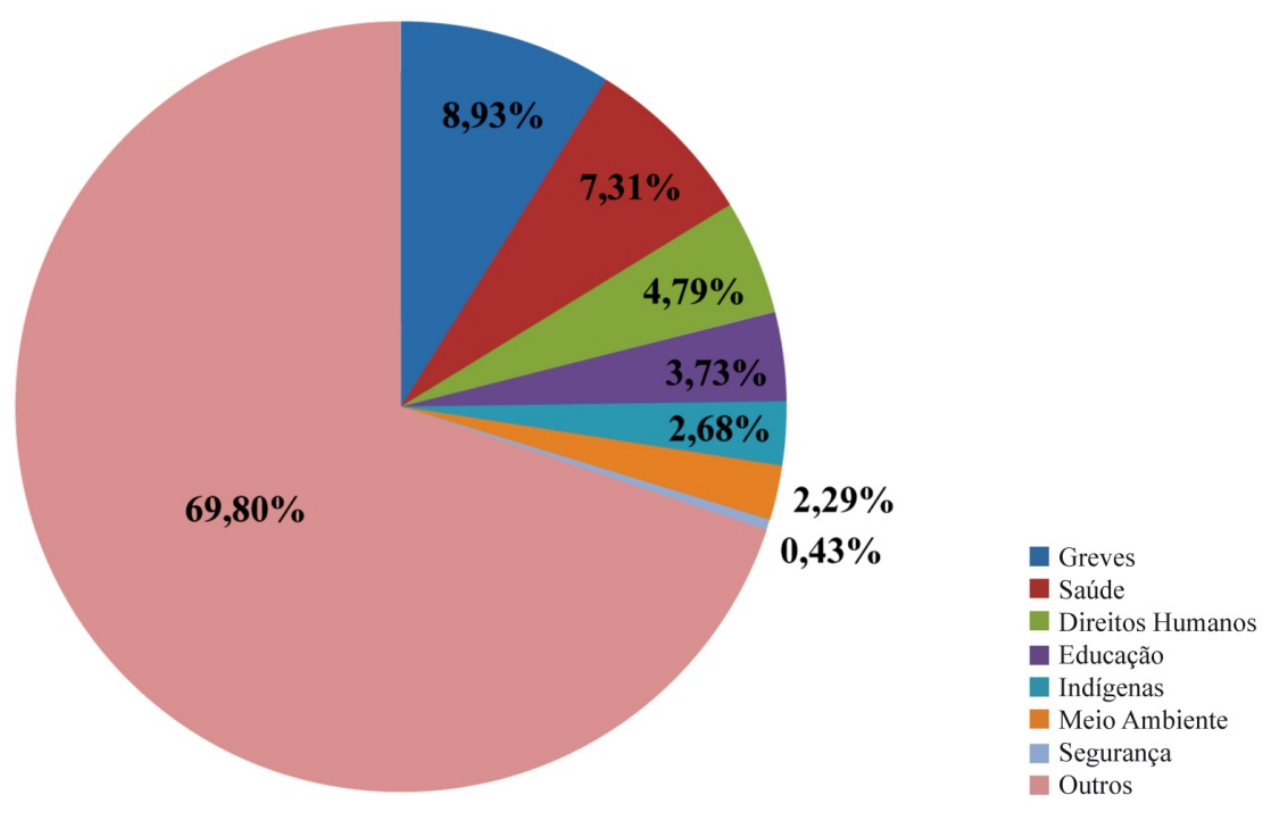

Gráfico 13: $\boldsymbol{J B H}$ - Temas de Interesse Católico. Greves: 6 notícias, 9’39. Saúde: 6 notícias, 7’54. Direitos Humanos: 3 notícias, 5'11. Educação: 2 notícias, 4'02. Indígenas: 3 notícias, 2'54. Meio Ambiente: 1 notícia, 2'29. E Segurança: 1 notícia, 0’28.

No caso do JCN, as notícias relacionadas aos temas considerados de interesse do jornalismo católico estavam distribuídas pelas editorias de Política, Geral, Economia e Internacional. Essas ocupavam a seguinte ordem na amostra selecionada, em relação ao tempo

\footnotetext{
90 Abordando a Lei de Logística Reversa, que deverá ser implantada em 2014. De autoria do padre redentorista Evaldo César, com 2’29.

91 No dia 15/08/2012, Despenca a venda legal de armas de fogo no Brasil (0’28), em Geral.
} 
total do radiojornal (1h49’17): as notícias sobre Greves ${ }^{92}$ (4) aparecem em primeiro lugar em termos de tempo, representando 4' 44 ou 4,37\% do total do radiojornal; em segundo, vêm as notícias sobre Educação ${ }^{93}$ (3), com 4’44 ou 4,37\% do total do radiojornal; na sequência, em terceiro, foram encontradas notícias relacionadas a Saúde (3; 2’20 ou 2,07\% do total do tempo de noticiário $)^{94}$, que, apesar de ocuparem o mesmo tempo de Manifestações de Trabalhadores (2; 2’20 ou 2,07\% do total) ${ }^{95}$, contabilizaram uma notícia a mais; a seguir, em quinto, vem uma notícia sobre Negociação Sindical $^{96}$; em sexto, Direitos Humanos (2; 1’07 ou 1,03\% do total) ${ }^{97}$; e, por fim, em sétimo, uma notícia sobre ações de populações Indígenas (1; 0’35 ou 0,53\% do total do noticiário) ${ }^{98}$, como pode ser observado no Gráfico 14.

92 No dia 07/08/2012: Policiais Federais iniciam hoje greve em todo o País (1’55). No dia 15/08/2012, Servidores do INSS fazem paralisação de 24 horas para pedir a negociação de pauta de reivindicações da categoria com melhores salários e condições de trabalho (1'16), ambas em Geral. E, no dia 31/08/2912, Governo anunciou que 93\% dos servidores em greve aceitaram o reajuste oferecido pelo Ministério do Planejamento (1'33), em Economia.

${ }^{93}$ No dia 30/07/2012, Ministério da Educação vai apresentar manual com as novas regras da redação do Enem (0’17), em Geral. No dia 15/08/2012, Ideb 2011 revela avanço na educação básica, mas ensino preocupa (3’12), em Política. E no dia 23/08/2012, Governo defende 100\% dos royalties do petróleo para a Educação (1’14), em Política.

${ }^{94}$ No dia 30/07/2012, Brasil luta para combater o consumo de drogas (0’24) e PROCON do Rio de Janeiro assina acordo que garante reposição de produto com validade expirada (027) em Geral. E no dia 23/08/2012, Campanha de atualização da caderneta de vacinação infantil termina em todo o País (1’24), também em Geral.

${ }^{95}$ No dia 30/07/2012, Manifestação de caminhoneiros deixa trânsito lento na Via Dutra (0’59), em Geral; e, no dia 15/08/2012, No Rio de Janeiro, manifestação de motoristas de vans deixa trânsito parado na Zona Norte (1’13), ambas em Geral.

${ }^{96}$ No dia 31/08/2012, Funcionários da General Motors de São José dos Campos, no interior de São Paulo, aprovaram acordo firmado entre a montadora e o Sindicato dos Metalúrgicos (2’00), em Economia.

${ }^{97}$ No dia 23/08/2012, Anistia Internacional avalia que os civis da Síria vivem em um nível terrível de violência depois de 17 meses de confrontos e mais de 20 mil mortos no país (0’30), em Internacional. E no dia 31/08/2012, Comissão da Verdade recomendou à Justiça de São Paulo que mude o registro do óbito do jornalista Vladimir Herzog (0’37), em Geral.

${ }^{98}$ No dia 23/08/2012, Sete mil indígenas e quilombolas fizeram marcha até o Palácio do Planalto nesta quintafeira (0’35), em Geral. 


\section{$J C N$ - Temas de Interesse Católico}

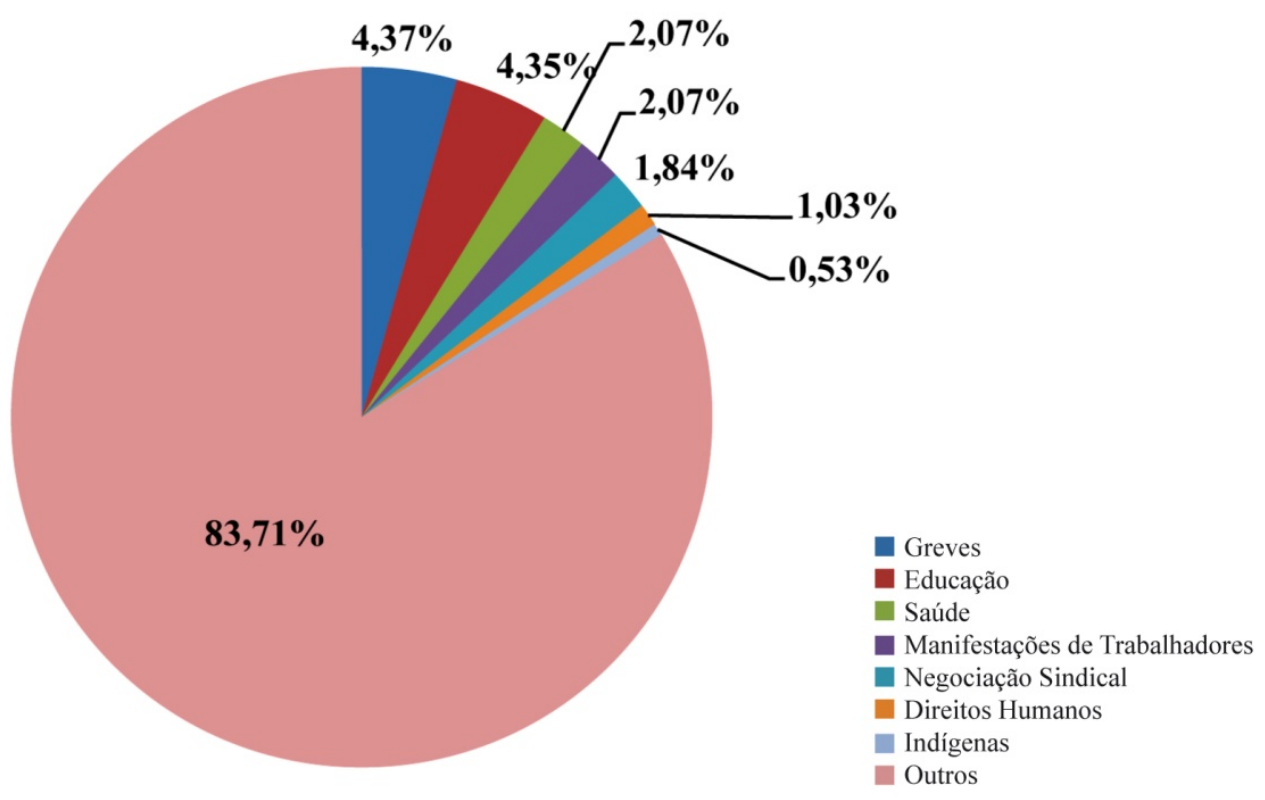

Gráfico 14: JCN - Temas de Interesse Católico. Greves: 4 notícias, 4'44. Educação: 3 notícias, 4'43. Saúde: 3 notícias, 2’20. Manifestações de Trabalhadores: 2 notícias, 2'20. Negociação Sindical: 1 notícia, 2’00. Direitos Humanos: 2 notícias, 1'07. E Indígenas: 1 notícia, 0’35.

Quando se analisa o total de tempo que cada um dos radiojornais dedicou aos temas considerados de interesse específico do jornalismo evangelizador ou católico, os resultados demonstram, na amostra analisada, que o $J B H$, da Rádio Aparecida, destinou 32’37 ou 30,20\% do total do noticiário para tais tipos de notícias, conforme pode ser constatado no

\section{Gráfico 15.}




\section{$J B H$ - Temas de Interesse Católico Total}

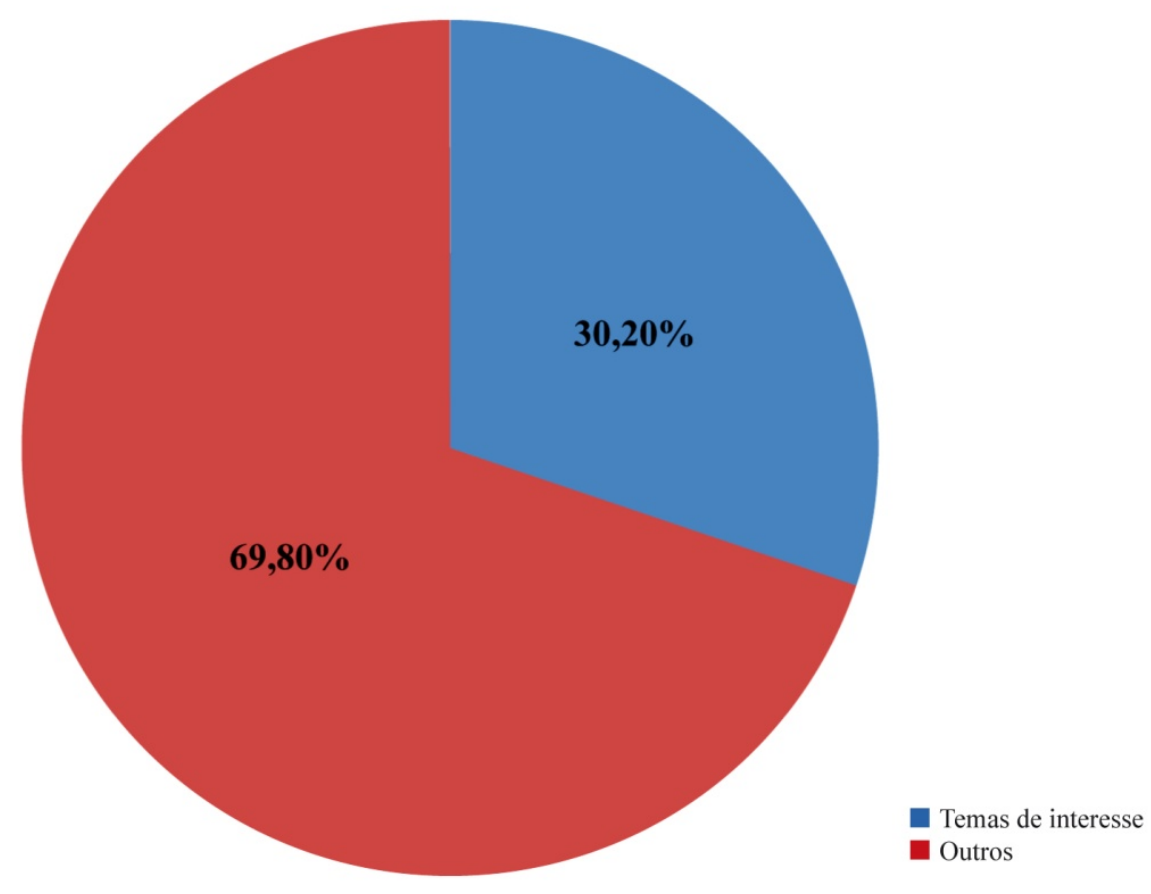

Gráfico 15: $\boldsymbol{J B H}$ - Temas de Interesse Católico Total. O JBH destinou 32’37 do total do radiojornal para notícias relacionadas aos temas de interesse católico. Notícias sobre outros temas ocuparam 1h16'23 do noticiário.

No restante do radiojornal, foram veiculadas notícias sobre Política (com destaque para o julgamento do Mensalão, agenda e pronunciamentos da presidente da República), Economia (notícias sobre investimentos federais e estaduais, infraestrutura, telecomunicações e índices econômicos), Geral (serviços, condições e efeitos do clima e previsão do tempo) e Esportes (resultados das Olimpíadas de Londres).

Já no JCN, as notícias relacionadas especificamente aos temas de interesse católico ou evangelizador ocuparam 17’39 ou 16,29\% do total do radiojornal da Canção Nova, como pode ser verificado no Gráfico 16. 


\section{$J C N$ - Temas de Interesse Católico Total}

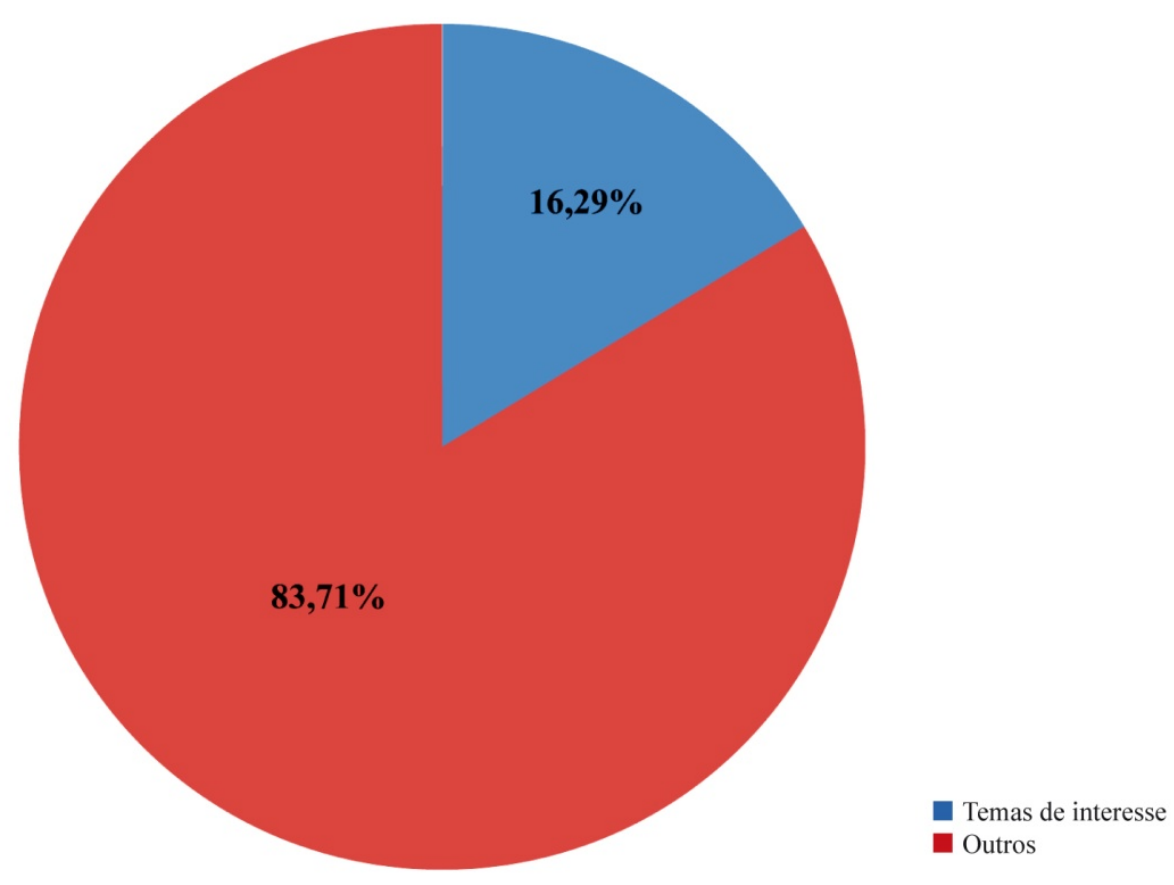

Gráfico 16: JCN - Temas de Interesse Católico Total. O JCN destinou 17’39 do total do radiojornal para notícias relacionadas aos temas de interesse católico. Notícias sobre outros temas ocuparam 1h32'21 do noticiário.

No restante do radiojornal, foram veiculadas notícias sobre Política (também destaque para o julgamento do Mensalão, agenda e pronunciamentos da presidente da República), Economia (indicadores, resultados e índices econômicos), Geral (prestação de serviços, condições e efeitos do clima e previsão do tempo), Internacional e Esportes (resultados das Olimpíadas de Londres e das rodadas do Campeonato Brasileiro). 


\subsection{Análise dos resultados}

A análise quantitativa das amostras de noticiário selecionadas em termos de percentual de tempo e número de notícias apresentados permitiu constatar que, em relação às editorias, os radiojornais das duas emissoras escolhidas apresentaram-se aos ouvintes com uma estrutura jornalística semelhante à dos grandes meios, observando a classificação descrita pelo jornalista e professor da PUC de Campinas Mário Erbolato em seu conhecido estudo Técnicas de Codificação em Jornalismo: Redação, Captação e Edição no Jornal Diário (ERBOLATO, 1984, pp.199-206).

O Jornal Brasil Hoje (JBH), da Rádio Aparecida, apresentou maior quantidade de notícias de Política (27), que ocuparam 31,03\% do radiojornal (33’31), seguidas pelas notícias de Geral (27,88\% ou 30’07), depois Economia (23, 23,58\% ou 25’28). A seguir, vem a seção Editorial (total de 5 notícias), que representou 9,87\% ou 10’40 do total do radiojornal, seguida pelas notícias de Religião (2; 5,67\% ou 7’08 do radiojornal) e Esporte (1; 1,94\% ou 2’06).

No caso do Jornal Canção Nova $2^{a}$ Edição (JCN), a maior parte do tempo da amostra do noticiário estudada foi dedicada às notícias de Geral (29), com 23,94\% ou 25’56, seguidas pelas notícias de Política (11), com 20,54\% ou 22’15, depois por Economia (17, com 18,22\% ou 19`44), Religião (14, com 14,49\% ou 15’42), Esporte (9, com 13,99\% ou 15’09), Internacional (14, com 7,72\% ou 8’22) e Institucional (2, com 1,06\% ou 1’09).

O levantamento do percentual das editorias permitiu, também, determinar a presença ou “prevalência” da Igreja Católica, em cada um dos radiojornais. Para tanto, foram consideradas, no caso do $\mathrm{JBH}$, todas as notícias que tratavam de acontecimentos sobre a Igreja Católica ou seus representantes, agrupadas na editoria de Religião (2 notícias totalizando 6’08), mais as que tinham fonte ou referências católicas (3 ou 3’30) ou que promoviam a opinião da instituição (5 ou 10`40) no caso da seção Editorial do $J B H$.

No JCN, foram contabilizadas as notícias de Religião (14 ou 15’42) mais uma notícia que apresentava uma fonte entrevistada católica (1’42), e ainda outras 2 notícias sobre ações e atividades de instituições católicas, agrupadas em Institucional (1’09). 
Esse recorte permitiu concluir que o peso da presença da Igreja Católica foi maior na Rádio Aparecida (23’16”, ou 21,54\% do tempo total do $J B H$ ) que na Rádio Canção Nova (18’34”, ou 17,14\% do $J C N$ ). Apesar de, à primeira vista, as notícias da editoria de Religião ocuparem um espaço significativamente menor em tempo e quantidade no caso do $J B H$ - com 5,67\%, ou somente 6’08 e duas notícias, contra os 14,49\% ou 15’42 e 14 notícias do JCN -, o radiojornal da Rádio Aparecida acabou por apresentar um peso maior da presença da Igreja Católica em seu noticiário que o da Rádio Canção Nova, o que coloca a emissora redentorista à frente da representante da Renovação Carismática em termos de tempo dedicado à instituição nos radiojornais analisados (diferença de 4’42 ou 4,4\%).

A Rádio Canção Nova, segundo se pôde constatar na amostra analisada e, de acordo com as informações fornecidas por sua editora, Catarina Jatobá, tem por rotina abrir o noticiário com notícias sobre o Vaticano, reproduzindo declarações e informando sobre as atividades do papa e sobre eventos da Igreja Católica, o que confere um caráter de destaque às notícias sobre a instituição.

Tal resultado é reforçado quando se realiza a observação das fontes entrevistadas na amostra escolhida. No $J B H$, as fontes que mereceram maior tempo de entrevista foram as eclesiais: 3 fontes totalizando 5’ 42 , o que representou 29,71\% do tempo total de entrevistas (19'11) ou 5,27\% do radiojornal. Em seguida, estavam as fontes governamentais: 9, com um tempo de 4'24, o que representa 22,93\% do total de entrevistas ou 4,07\% do radiojornal. Logo após, vieram as fontes sindicais: 5, com 4’11, representando $21,80 \%$ do total de entrevistas e 3,87\% do tempo de radiojornal. Os especialistas (8) mereceram um total de 1'49 de sonoras, representando $14,68 \%$ do tempo total de entrevistas ou 2,60\% de radiojornal. As fontes judiciais (2) totalizaram 0 ' 47 , ou $4,08 \%$ do tempo de entrevistas e $0,72 \%$ de radiojornal. As fontes empresariais (2), em seguida, ocuparam 0’35 de tempo de sonoras, 3,04\% das entrevistas e $0,54 \%$ de radiojornal. As fontes independentes (somente uma) seguiram, com 0’23, $1,99 \%$ e $0,35 \%$, respectivamente. Por fim, os protagonistas (1), mereceram somente 0’20 de sonora, representando 1,73\% do total de entrevistas e $0,30 \%$ de radiojornal.

O JCN, por sua vez, dedicou maior tempo às fontes governamentais (5), com total de 3’08 de entrevistas, o que representou 35\% do tempo total de sonoras (8’57) e 2,89\% de radiojornal. A seguir, vieram as fontes eclesiais (2), totalizando 2’22, com percentual de $26,44 \%$ do total de entrevistas e 2,10\% do radiojornal. As fontes judiciais (somente uma), 
ocuparam tempo de 1'09, representando $12,84 \%$ das entrevistas e 1,06\% de radiojornal. Os especialistas (3) representarm 0’56 ou 10,42\% do total de entrevistas ou 0,86\% do radiojornal. Os protagonistas (3) totalizaram 0’51, 9,42\% das entrevistas e 0,78\% de radiojornal. As fontes legislativas (2) vieram em seguida, com 0’23, 4,20\% das entrevistas e 0,35\% do radiojornal. E, por fim, apareceram as fontes empresariais (1), com 0’08 de tempo, 1,48\% ou $0,12 \%$ das entrevistas e do radiojornal, respectivamente.

Na comparação entre os dois radiojornais, observou-se que as fontes eclesiais foram as que mereceram maior tempo de entrevistas no caso da emissora redentorista. Tais fontes destacaram-se em termos de quantidade e de tempo na amostra da Rádio Aparecida (3 fontes com 5’42 de sonora ou 29,71\% do tempo total de entrevistas do radiojornal), em relação ao noticiário da Rádio Canção Nova (2 sonoras totalizando 2’22 ou 26,44 do total de entrevistas). A diferença fica ainda mais evidenciada quando se considera o tempo de entrevistas dessas fontes em relação do tempo total de cada um dos radiojornais. Dessa forma, as fontes eclesiais representaram 5,27\% do $J B H$ e $2,10 \%$ do $J C N$.

A análise dos temas de interesse específicos do jornalismo católico ou evangelizador (foram identificados sete temas no radiojornal), conforme indicados pelos documentos oficiais da Igreja e pelos entrevistados citados, demonstrou que no $J B H$, em relação ao tempo total de noticiário (1h49), as notícias sobre Greves (6) ocuparam a maior parte, ou o primeiro lugar em tempo, dos temas elencados em relação ao noticiário: 9’39, o que representou 8,93\% do total do radiojornal. Em segundo lugar, estavam notícias sobre Saúde (6), ocupando 7’54 ou 7,31\% do tempo total do radiojornal. A seguir, em terceiro, as notícias sobre Direitos Humanos (3), com 5’11 ou 4,79\% do radiojornal, seguidas, em quarto, por Educação (2), com 4’02 ou 3,73\% e, em quinto, notícias relacionadas às populações Indígenas (3) 2’54 ou 2,68\%. Em sexto lugar, vem o editorial do dia 31/08/2012, sobre o tema Meio Ambiente (2’29 ou 2,29\%). E, por fim, em sétimo, uma notícia abordando o tema Segurança (0’28 ou 0,43\%).

No caso do JCN, as notícias consideradas de interesse do jornalismo católico estavam distribuídas também em sete temas. Em relação ao tempo total do radiojornal (1h49’17), as notícias sobre Greves, à semelhança do $J B H$, aparecem em primeiro lugar: 4, com tempo de 4’44 ou 4,35\% do total do radiojornal. Em segundo, vêm as notícias sobre Educação (3), com 4’43 ou 4,35\% do total do radiojornal. Na sequência, em terceiro, foram encontradas notícias relacionadas ao tema Saúde (3), com 2’20 ou 2,07\% do total do tempo de noticiário, seguidas, 
em quarto, por Manifestações de Trabalhadores (2), com tempo igual ao anterior 2'20 ou 2,07\% do total. A seguir, em quinto, vem uma notícia sobre Negociação Sindical, com 2’00 ou 1,84\%, seguida por 2 notícias sobre Direitos Humanos (1’07 ou 1,03\% do total). E, por fim, em sétimo, uma notícia sobre movimentos de populações Indígenas (0’35 ou 0,53\% do total do noticiário).

A análise dos radiojornais das duas emissoras demonstra que essas estão atentas e alinhadas às diretrizes da Igreja Católica na divulgação de fatos considerados importantes para os que praticam um jornalismo católico ou evangelizador. Entretanto, os resultados mostraram que, na amostra analisada, a Rádio Aparecida dedicou um tempo significativamente maior (de 32’37 ou 30,20\% do radiojornal) na divulgação de tais tipos de notícias. Na Rádio Canção Nova, o tempo de noticiário voltado aos temas de interesse do jornalismo católico ou evangelizador foi de 17’39 ou 16,29\% do total do radiojornal.

Em resumo, uma vez feito o levantamento percentual quantitativo e de tempo a que se propôs este estudo, conclui-se que os dois radiojornais analisados apresentam estrutura semelhante ao noticiário de empresas jornalísticas leigas, com o diferencial de incluírem um significativo conteúdo religioso ou católico. Esse conteúdo foi maior na Rádio Aparecida, em que o percentual de notícias sobre a Igreja Católica - com fontes religiosas e mais os editoriais veiculando a opinião da instituição - representou 21,54\% da amostra total do radiojornal da emissora redentorista, contra os $17,14 \%$ da Rádio Canção Nova, em que foram observadas 14 notícias sobre a Igreja Católica mais duas institucionais sobre as atividades da comunidade a que pertence a rádio.

A presença da Igreja Católica é também maior em relação às fontes entrevistadas, sendo que, no $J B H$, as fontes eclesiais mereceram tempo maior de sonora - três fontes totalizando 5’42, o que representou 29,71\% do tempo total de entrevistas (19'11) ou 5,27\% do radiojornal -, enquanto, na emissora representante da Renovação Carismática, as fontes eclesiais (duas) aparecem em segundo lugar, totalizando 2'22, com percentual de $26,44 \%$ do total de entrevistas e $2,10 \%$ do radiojornal.

O noticiário da Rádio Aparecida apresentou quase o dobro do número de entrevistados (30) na amostra estudada, em comparação ao jornal da Rádio Canção Nova (17). A fonte que mereceu maior tempo de sonora na Aparecida foi dom Raymundo Damasceno Assis, 
presidente da CNBB e arcebispo de Aparecida (3’03). Já na Canção Nova, uma fonte governamental, o ministro da Educação, Aloizio Mercadante, foi o entrevistado com maior tempo de sonora (com 1'11). 


\section{CONSIDERAÇÕES FINAIS}

A análise dos documentos oficiais da Igreja Católica permite observar a importância que a instituição confere aos meios de comunicação em sua missão de evangelizar. Uma vez confirmada a hipótese central deste estudo, de que os veículos de comunicação católicos, neste caso as rádios, são utilizados para tal propósito, constata-se que as emissoras estudadas voltam sua programação para divulgar a mensagem do Evangelho e sua "Boa Notícia”, nela inserida a prática do jornalismo, conforme evidenciado pelas entrevistas realizadas com profissionais das rádios estudadas e com representantes da Igreja Católica.

As entrevistas a esses profissionais e representantes, as consultas aos documentos oficiais da Igreja, assim como o levantamento bibliográfico e o exame das amostras dos radiojornais estudados, possibilitaram levantar algumas características do jornalismo praticado nessas emissoras.

Ao fazerem jornalismo, as duas rádios estudadas, a Aparecida AM e a Canção Nova AM, assumem claramente uma posição de fortalecimento da presença da Igreja Católica no Brasil, reconhecem a disposição de serem a voz da instituição e de defenderem seus pontos de vista, ao mesmo tempo em que buscam atender às expectativas do enorme contingente de ouvintes católicos, público para o qual sua programação está voltada.

Representando diferentes movimentos dentro da Igreja Católica - a Rádio Aparecida, de orientação Redentorista, e a Rádio Canção Nova, alinhada à Renovação Carismática Católica -, as emissoras evidenciam algumas posturas diferenciadas em relação a seus noticiários.

A Aparecida, com grande tradição no fazer jornalístico, sempre procurou privilegiar a veiculação da opinião, não raro assumindo posturas críticas em relação a governos e à sociedade, por meio dos editoriais presentes em seu noticiário. Os responsáveis pela emissora afirmam ter na prática jornalística uma forma não apenas de informar seus ouvintes, mas também de oferecer a esse público a posição e a ótica da Igreja Católica sobre os fatos correntes, e de promover junto a esses ouvintes os valores e princípios cristãos. Além disso, 
segundo dizem, procuram fazer despertar em seu público a consciência para o exercício da cidadania.

A emissora demonstra estar atenta a uma gama diferenciada de vozes sociais, representadas pelas fontes entrevistadas no noticiário analisado - conforme demonstra o levantamento realizado nesta pesquisa -, embora confira um espaço privilegiado às fontes eclesiais, com destaque para o arcebispo de Aparecida e presidente da Conferência Nacional dos Bispos do Brasil (CNBB), dom Raymundo Damasceno Assis, que mereceu maior tempo de sonoras na amostra do noticiário analisado.

Por sua vez, a Rádio Canção Nova opta por dar destaque às notícias sobre a Igreja Católica no Brasil e no mundo, procurando sempre privilegiar a agenda e pronunciamentos de seu representante máximo, o papa ${ }^{99}$. No radiojornal da emissora carismática, as notícias religiosas rotineiramente abrem o noticiário e ocupam parcela significativa do primeiro bloco. A rádio utiliza, ainda, notas de promoção institucional em seu noticiário, o que não se observou na Aparecida.

Não se revela por parte da Rádio Canção Nova uma disposição de estabelecer polêmica, uma vez que a emissora não veicula editoriais, limitando-se o seu noticiário ao conteúdo informativo. Os slogans "Uma emissora a serviço da vida e da esperança” e "Nós espalhamos o amor pelo ar" podem ser interpretados como indicativos de um posicionamento menos combativo, evidenciando uma atitude positiva de seus profissionais em relação à produção jornalística, em que assumidamente se evita pautar notícias sobre violência ou escândalos. A rádio carismática utiliza bem menos o recurso da entrevista, tanto em termos de número de entrevistados quanto em termos de tempo dedicado a essas vozes, quando comparada à emissora redentorista.

A existência de diferentes formas de jornalismo, voltadas para distintos segmentos da população, resultam benéficas para os ouvintes, na medida em que essas atendem ao direito que cada público tem de ser informado sobre tudo que é de seu interesse. As emissoras estudadas, apesar de classificadas como comerciais, dispõem ainda da vantagem de poderem

\footnotetext{
${ }^{99}$ Na amostra, o ainda pontífice Bento XVI, que, após renunciar, em 28 fevereiro de 2013, tornou-se papa emérito, sendo substituído pelo cardeal arcebispo de Buenos Aires, Jorge Mario Bergoglio, eleito como papa Francisco, em 13 de março de 2013. Ver depoimento do papa Francisco durante a Jornada Mundial da Juventude, realizada de 23 a 28 de julho de 2013, no Rio de Janeiro, sobre a importância do rádio, no Anexo 1.
} 
contar com a contribuição dos ouvintes, para sua manutenção. No caso da Aparecida, o Clube dos Sócios garante a maior parte das verbas da rádio. Na Canção Nova, as campanhas de arrecadação permitem à emissora manter-se apenas por meio desse sistema. Tal forma de financiamento possibilita, assim, às duas emissoras garantir independência editorial em relação à realidade de mercado a que as demais rádios comerciais estão permanentemente subordinadas.

A reflexão que se coloca aos profissionais responsáveis pelos radiojornais, entretanto, é no sentido de buscarem a medida do equilíbrio em relação à quantidade de tempo que o peso do noticiário de cunho religioso e as notícias de promoção institucional representam em relação ao total do noticiário, tendo em vista o interesse público e a responsabilidade social que a atividade jornalística enseja.

A evangelização pela notícia presta um serviço à sociedade, na medida em que garante espaço a causas sociais no noticiário e procura promover os valores humanos, defender a vida e lutar por justiça, conforme indicam entrevistados, fontes consultadas e segundo documentos norteadores como o Gaudium et Spes, que exorta a Igreja Católica e seus representantes a solidarizarem-se “com as alegrias, tristezas e dores da humanidade”. Entretanto, o jornalismo produzido em um contexto religioso pode assumir um caráter proselitista, quando se apresenta como mera ferramenta de promoção institucional, perdendo de vista sua missão pública.

Uma forma de se alcançar mais equilíbrio na atividade jornalística desenvolvida nesse contexto seria a abertura no noticiário a uma multiplicidade de fontes, a serem ouvidas em cada notícia, a fim de mostrar os diversos ângulos dos fatos cotidianos, em especial no caso dos que estão relacionados a alguma polêmica envolvendo a Igreja Católica. Quanto mais se alinharem aos tradicionais cânones do jornalismo, como a procura pela veracidade e a abertura à diversidade de vozes, mais essas emissoras estarão promovendo a democratização de seu serviço noticioso, a qual resulta da receptividade à participação dos diferentes atores sociais envolvidos nos fatos narrados.

Em que pese o fato de os dois radiojornais estudados terem alcance nacional e, dessa forma, dirigirem-se a um público bastante heterogêneo, outro passo que possivelmente poderia ser tomado na busca por um noticiário mais adequado às exigências do público, seria a ampliação da participação do ouvinte por meio dos canais de interação representados pelas 
redes sociais, algo que as duas rádios já disponibilizam em seus sites, mas que poderiam dinamizar ainda mais.

Outro instrumento que contribuiria para garantir a defesa na busca por equilíbrio do conteúdo da informação produzida por esses noticiários é a instituição de uma figura como um ombudsman, que se ocuparia de receber críticas e sugestões do público e repassá-las aos responsáveis pelos noticiários. Creditado com esse mandato, um profissional como esse seria capaz de oferecer um contraponto crítico às edições diárias dos radiojornais, a fim de preservar seu teor social e educativo, algo a que a grande imprensa já recorre há tempos e que poderia ser implantado pelas rádios do segmento católico.

Em última análise, considera-se que as emissoras pertencentes a grupos religiosos, em particular, as rádios católicas, têm uma dupla missão. Além da responsabilidade social relacionada às atividades da radiodifusão e do jornalismo, cabe a essas emissoras assumir e desempenhar um papel orientador e educativo, uma vez que optaram por apresentar à sociedade uma mensagem permeada pela promoção dos valores humanos, segundo argumentam seus representantes, e atendendo à própria expectativa de seu público. $\mathrm{Na}$ condição de contempladas com concessões públicas e, ao exercerem o jornalismo, as emissoras de rádio católicas assumem compromisso social e cidadão que deve colocar-se acima de qualquer interesse. 


\section{REFERÊNCIAS BIBLIOGRÁFICAS}

ABIB, Jonas. Canção Nova: Uma obra de Deus - Nossa história, identidade e missão. São Paulo, SP: Canção Nova, 2000.

ALTHUSSER, Louis. Aparelhos Ideológicos de Estado: nota sobre os aparelhos ideológicos de estado. Rio de Janeiro: Edições Graal, 1985.

ARENDT, Hannah. A Condição Humana. Rio de Janeiro: Forense, 1987.

BARBOSA FILHO, André. Gêneros radiofônicos: Os formatos e os programas em áudio. São Paulo: Paulinas, 2003.

BELTRÃO, Luiz. Iniciação à Filosofia do Jornalismo. São Paulo: Edusp, 2003. - Teoria e Prática do Jornalismo. Adamantina: FAI/Cátedra Unesco Metodista de Comunicação para o Desenvolvimento Regional/Edições Omnia, 2006.

BOMBONATTO, Vera I. Evangelizar é Comunicar. São Paulo: Paulinas, 2009.

ALTEMEYER JR., Fernando (Org.). Teologia e Comunicação: Corpo, palavra e interfaces cibernéticas. São Paulo: Paulinas, 2011.

BOND, Fraser. Introdução ao Jornalismo: uma análise do quarto poder em todas as suas formas. Rio de Janeiro: Agir, 1962.

BUCCI, Eugênio. Sobre Ética e Imprensa. São Paulo: Cia. das Letras, 2000. . A Imprensa e o Dever da Liberdade. São Paulo: Contexto, 2009. 
CARDOSO, Marcelo. O Jornalismo Radiofônico e as Narrativas Vinculadoras: experiências de emissoras paulistanas. Dissertação (Mestrado em Comunicação). Faculdade Cásper Líbero, São Paulo, 2010.

CNBB. Estudo 101. A Comunicação na Vida e na Missão da Igreja no Brasil. São Paulo: Paulus, 2011.

. Estudo 94. Diretrizes Gerais da Ação Evangelizadora da Igreja no Brasil 2011-2015. Brasília: Edições CNBB, 2011.

- Documento 59. Igreja e Comunicação Rumo ao Novo Milênio: Conclusões e Compromissos. São Paulo, Paulinas, 1997).

CORAZZA, Helena. O Lugar da Religião no Rádio. In: BARBOSA, André; BENETON, Rosana. Rádio: Sintonia do Futuro. São Paulo: Paulinas, 2004.

. Comunicação e Relações de Gênero em Práticas Radiofônicas. São Paulo: Paulinas, 2000.

. PUNTEL, Joana. Pastoral da Comunicação: Diálogo entre Fé e Cultura. São Paulo: Paulinas, 2007.

CHAPARRO, Manuel Carlos. Pragmática do jornalismo - buscas práticas para uma teoria da ação jornalística. 3.ed. rev. São Paulo: Summus, 2007.

COVRE, Maria de Lourders Manzini. O que é Cidadania. São Paulo: Brasiliense, 2003.

DALMOLIN, Aline Roes. O Discurso sobre Aborto em Revistas Católicas Brasileiras: Rainha e Família Cristã (1980-1990). Tese de Doutorado. São Leopoldo: PPGCOM/Unisinos, 2012. 
DARIVA, Noemi (org.). Comunicação Social na Igreja: documentos fundamentais. São Paulo: Paulinas, 2003.

DE ANGELIS, Sandra. Complexo Empresarial com Foco no Cliente. In Paróquias \& Casas Religiosas, Ano 2 No 7 - julho-agosto 2007. São Paulo: Promocat.

O Poder da Mensagem. In: Paróquias \& Casas Religiosas, Ano 2 № 11 - marçoabril 2008. São Paulo: Promocat.

DUARTE, J. A Entrevista em Profundidade. In: DUARTE, J; BARROS, A. (orgs.). Métodos e Técnicas de Pesquisa em Comunicação. São Paulo: Atlas, 2005.

ERBOLATO, Mário L. Técnicas de Codificação em Jornalismo: Redação, Captação e Edição no Jornal Diário. Petrópolis: Vozes, .

FERRARETTO, Luiz Artur. Rádio: o veículo, a história e a técnica. Porto Alegre, RS: Editora Sagra Luzzatto, 2001.

FOLGOLARI, Élide M.; BORGES, Rosane da S. Novas Fronteira da Pastoral da Comunicação: Diretrizes e Propostas de Atuação. São Paulo: Paulinas, 2009.

GENTILLI, Victor. Democracia de Massas: Cidadania e Informação. Dissertação (Mestrado em Ciências da Comunicação) - Escola de Comunicações e Artes da Universidade de São Paulo, São Paulo, 1995.

GASPARETTO, Paulo R. Midiatização da Religião: Processos Midiáticos e a Construção de Novas Comunidades de Pertencimento. São Paulo: Paulinas, 2011.

GOMES, Pedro Gilberto. Da Igreja Eletrônica à Sociedade em Midiatização. São Paulo: Paulinas, 2010. 
HOUAISS, Antonio. Dicionário Houaiss da Língua Portuguesa. Rio de Janeiro: Objetiva, 2001.

KOVACH, Bill e ROSENSTIEL, Tom. Os Elementos do Jornalismo: o que os jornalistas devem saber e o público exigir. $2^{\mathrm{a}}$ Edição. Tradução: Wladir Dupont. São Paulo: Geração Editorial, 2004.

KUNCZIK, Michael. Conceitos de Jornalismo. $2^{\mathrm{a}}$ Edição. Tradução: Rafael Varela Jr. São Paulo: EDUSP, 2001.

LAGE, Nilson. A Reportagem: Teoria e Técnica de Entrevista e Pesquisa Jornalística. Rio de Janeiro: Record, 2001.

Ideologia e técnica da notícia. Florianópolis: Insular \& EDUFSC, 2001.

LIBANIO, J.B. Cenários de Igreja num Mundo Plural e Fragmentado. São Paulo: Edições Loyola, 2012.

MALULY, Luciano Victor Barros. Berro! Manifesto para a ampliação das notícias e das vozes no radiojornalismo brasileiro. IN Revista Sem Terra. Ano X. No 40. São Paulo: Gráfico Efeito, Julho/Agosto 2007.

_ Entre o possível e o recomendável - metodologia de pesquisa aplicada ao radiojornalismo. IN IX Congreso Latinoamericano de Investigadores de la Comunicación. Cidade do México: Alaic, 9 a 11 de outubro de 2008.

O Rádio Democrático - alternativas para a Ciência do Jornalismo. IN XXXI Congresso Brasileiro das Ciências da Comunicação. Natal: UFRN, 02 a 06 de setembro de 2008. 
MARQUES DE MELO, José. Comunicação eclesial: utopia e realidade. São Paulo: Paulinas, 2005.

A Questão da Comunicação Religiosa no Bicentenário da Imprensa Brasileira. Apresentação oral no III Eclesiocom 2008, São Bernardo do Campo: Umesp, 8 dez. 2008. Disponível em <http://www.metodista.br/eclesiocom/2008/a-questao-da-comunicacaoreligiosa-no-bicentenario-da-imprensa-brasileira> .

. SATHLER, Luciano (Orgs.). Direitos à Comunicação na Sociedade da Informação. São Bernardo do Campo: Umesp, 2005.

. GOBBI, Maria Cristina.; ENDO, Ana Cláudia B. (Orgs.). Mídia e religião na sociedade do espetáculo. São Bernardo do Campo: Universidade Metodista de São Paulo, 2007. p. 15-22.

A Opinião no Jornalismo Brasileiro. Petrópolis: Vozes, 1985.

Sociologia da Imprensa Brasileira. Petrópolis: Vozes, 1973.

MARSHALL, Thomas Humphrey. Cidadania, Classe Social e Status. Rio de Janeiro: Zahar, 1967.

MEDINA, Cremilda de Araujo. Profissão Jornalista: responsabilidade social. Rio de Janeiro: Editora Forense-Universitária, 1982.

MEDITSCH, Eduardo Barreto Vianna. Teorias do rádio: textos e contextos. Florianópolis: Insular, 2005, v. I. . Teorias do rádio: textos e contextos. Florianópolis: Insular, 2005, v. II. O rádio na era da informação. Coimbra: Minerva, 1999. 
O conhecimento do jornalismo. Florianópolis: Editora da UFSC, 1992.

MENEZES, José Eugenio de Oliveira. Rádio e Cidade: vínculos sonoros. São Paulo, Annablume, 2007.

Cultura do Ouvir: os vínculos sonoras na contemporaneidade. São Paulo: Plêiade, 2012.

MORAES JÚNIOR, Enio. O ensino do interesse público na formação dos jornalistas: elementos para a construção de uma pedagogia. Tese (Doutorado em Ciências da Comunicação) - Escola de Comunicações e Artes da Universidade de São Paulo, São Paulo, 2011.

A formação cidadã do jornalista no Brasil: um estudo de caso da formação do jornalista da USP. Dissertação (Mestrado em Ciências da Comunicação) - Escola de Comunicações e Artes da Universidade de São Paulo, São Paulo, 2005.

MOREIRA, Antônio César. Jornalismo e Evangelização: estudo sobre o “Jornal dos Jornais” da Rádio Aparecida entre 1987-1990. 1995. Monografia (Pós-graduação Lato Sensu). Serviço à Pastoral da Comunicação, São Paulo: 1995.

MOREIRA, Sonia Virgínia (Org.). 70 Anos de Radiojornalismo no Brasil: 1941-2011. Rio de Janeiro: EdUERJ, 2011.

NEOTTI, Clarêncio. Comunicação e Igreja no Brasil. Estudos da CNBB, 72. São Paulo: Paulus, 1994.

ORTRIWANO, Gisela. A Informação no Rádio: os grupos de poder e a determinação dos conteúdos. São Paulo: Summus, 1985. 
Radiojornalismo no Brasil. São Paulo: Com-Arte, 1987.

OTA, Daniela Cristina. A informação jornalística em rádios de fronteira. (Tese de Doutorado). São Paulo: ECA-USP, 2006.

PAIVA, Gilberto. Rádio Aparecida, 50 Anos de História. Aparecida: Santuário, 2001.

PARK, Robert E. A Notícia como Forma de Conhecimento. In: STEINBERG, Charles (Org.). Meios de Comunicação de Massa. São Paulo, Cultrix: 1996.

PERUZZO, Cicilia M. K. Ética, Liberdade de Imprensa, Democracia e Cidadania. In: Revista Brasileira de Ciências da Comunicação, Volume XXV, nº 2, julho/dezembro de 2002. São Paulo: Sociedade Brasileira de Estudos Interdisciplinares da Comunicação.

PUNTEL, Joana. A Igreja e a Democratização da Comunicação. São Paulo, Paulinas, 1994. Comunicação: Diálogo dos Saberes na Cultura Midiática. São Paulo, Paulinas: 2010. . A Igreja a Caminho na Comunicação. Revista Teocumunicação, Porto Alegre, v. 41, n. 2, p.221-242, jul/dez/ 20011.

QUEIROZ, Dulce. O Jornalismo Institucional nas TVs Legislativas: Os Casos do Brasil e do México. 2007. Dissertação de Mestrado. Programa de Pós-Graduação em Comunicação da Universidade de Brasília. Brasília.

RASLAN FILHO, Gilson Soares. Daí-me Almas: o pastoreio midiatizado da TV Canção Nova. Tese (Doutorado em Ciências da Comunicação) - Escola de Comunicações e Artes da Universidade de São Paulo, São Paulo, 2011. 
SANT'ANNA, Francisco. Mídia das Fontes: O Difusor do Jornalismo Corporativo. In: LOPES, Boanerges (Org.). Gestão em Comunicação Empresarial: Teoria e Técnica. Juiz de Fora: Universidade Federal de Juiz de Fora: 2007.

SILVA, André Chaves de Melo. Ensino de História, Cinema, Imprensa e Poder na Era Vargas. Dissertação (Mestrado em Educação). Faculdade de Educação da Universidade de São Paulo, São Paulo, 2005.

SILVA, Luiz Martins da. Jornalismo e Interesse Público. In: SEABRA, Manoel Roberto: SOUSA, Vivaldo de (Org.). Jornalismo Político - Teoria, História e Técnicas. Rio de Janeiro: Record, 2006.

SOARES, Ismar de Oliveira. Do Santo Ofício à Libertação: o discurso e a prática do Vaticano e da Igreja Católica no Brasil sobre a Comunicação. São Paulo: Paulinas, 1988.

TRAQUINA, Nelson. Teorias do Jornalismo: Porque as notícias são como são. Florianópolis: Insular, 2005a.

— Teorias do Jornalismo: A tribo jornalística - uma comunidade interpretativa transnacional. Florianópolis: Insular, 2005b.

TUCHMAN, Gaye. A objetividade como ritual estratégico: uma análise das noções de objetividade dos jornalistas. In TRAQUINA, Nélson. Jornalismo: Questões, Teorias e Estórias. Lisboa: Vega, 1999.

VIGIL, José Ignácio Lopes. Manual Urgente para Radialistas Apaixonados. São Paulo: Paulinas, 2003.

WOLF, Mauro. Teorias das Comunicações de Massa. $6^{\text {a }}$ Edição. Lisboa: Editorial Presença, 2001. 


\section{Documentos eletrônicos:}

ABREU, Alzira Alves de. Jornalismo Cidadão. Estudos Históricos, Rio de Janeiro, n. 31, 2540, 2003.

Disponível

em

http://bibliotecadigital.fgv.br/ojs/indez.php/reh/article/view/2185/1324.

CELAM, Documento de Puebla. http://www.pjtaubate.org/2009/documentos/documentodePuebla.pdf. Acesso em 14 de novembro de 2012.

- Documento de Santo Domingo. Disponível em http://www.celam.org/conferencias/Documento_Conclusivo_Santo_Domingo.pdf. Acesso em 14 de novembro de 2012.

- Documento de Aparecida. Disponível em http://www.celam.org/conferencia_aparecida.php. Acesso em 14 de novembro de 2012.

CNBB. Diretrizes Gerais da Ação Pastoral da Igreja no Brasil (1991-1994). Disponível em www.cnbb.org.br/.../107-45-diretrizes-gerais-da-acao-pastoral-da-igreja-no-brasil. Acesso em 14 de novembro de 2012.

. Diretrizes Gerais da Ação Evangelizadora da Igreja no Brasil (2011-2015). Disponível em http://www.cnbb.org.br/site/component/docman/cat_view/134-documentoscnbb. Acesso em 14 de novembro de 2012.

IGREJA CATÓLICA. Constituição Apostólica Gaudium et Spes - Sobre a Igreja no Mundo Atual.

Disponível 
em:http://www.vatican.va/archive/hist_councils/ii_vatican_council/documents/vatii_const_19651207_gaudium-et-spes_po.html. Consultado em 15 de novembro de 2012.

. Decreto Inter Mirifica, 1966. Disponível em http://www.vatican.va/archive/hist_councils/ii_vatican_council/documents/vatii_decree_19631204_inter-mirifica_po.html. Consultado em 15 de novembro de 2012. . Constituição Dogmática Lumen Gentium - Sobre a Igreja no Mundo. http://www.vatican.va/archive/hist_councils/ii_vatican_council/documents/vatii_const_19641121_lumen-gentium_po.html. Consultado em 15 de novembro de 2012. . A Nova Evangelização para a Transmissão da Fé Cristã: Instrumentum Laboris. XII Assembleia Geral Ordinária do Sínodo dos Bispos. Disponível em http://www.vatican.va/roman_curia/synod/documents/rc_synod_doc_20120619_instrumentu m-xiii_po.pdf. Consultado em 16 de novembro de 2012.

JOÃO PAULO II. As Comunicações Sociais a Serviço da Liberdade Responsável do Homem.

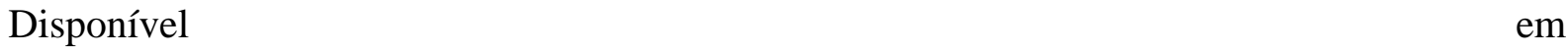
http://www.vatican.va/holy_father/john_paul_ii/messages/communications/documents/hf_jpii_mes_10051981_world-communications-day_po.html. Acesso em 15 de novembro de 2012. - Comunicações Sociais e Promoção de Justiça e da Paz. Disponível em http://www.vatican.va/holy_father/john_paul_ii/messages/communications/documents/hf_jpii_mes_24011987_world-communications-day_po.html. Acesso em 15 de novembro de 2012. —. Carta Encíclica Redemptoris Missio. Disponível em http://www.vatican.va/holy_father/john_paul_ii/encyclicals/documents/hf_jpii_enc_07121990_redemptoris-missio_po.html. Acesso em 15 de novembro de 2012. 
. Comunicar o Evangelho de Cristo: Caminho, Verdade e Vida. Disponível em http://www.vatican.va/holy_father/john_paul_ii/messages/communications/documents/hf_jpii_mes_24011997_world-communications-day_po.html. Acesso em 15 de novembro de 2012. . Os Meios de Comunicação a Serviço da Paz Autêntica, à Luz da Pacem in Terris. http://www.vatican.va/holy_father/john_paul_ii/messages/communications/documents/hf_jpii_mes_20030124_world-communications-day_po.html. Acesso em 15 de novembro de 2012 PAULO VI. Exortação Apostólica Evangelii Nuntiandi. Disponível em http://www.vatican.va/holy_father/paul_vi/apost_exhortations/documents/hf_pvi_exh_19751208_evangelii-nuntiandi_po.html. Consultado em 19 de novembro de 2012. . As Comunicações Sociais e a Evangelização no Mundo Contemporâneo. Disponível em http://www.paulinos.org.br/comunicacao/pdfs/paulovi/As\%20comunica\%C3\%A7\%C3\%B5es \%20sociais\%20e\%20a\%20evangeliza\%C3\%A7\%C3\%A30\%20no\%20mundo\%20contempor \%C3\%A2neo\%201974.pdf. Acesso em 19 de novembro de 2012.

PIO XII, Carta Encíclica Miranda Prorsus, 1957. Disponível em http://www.vatican.va/holy_father/pius_xii/encyclicals/documents/hf_pxii_enc_08091957_miranda-prorsus_po.html. Consultado em 19 de novembro de 2012.

PONTIFÍCIO CONSELHO PARA AS COMUNICAÇÕES SOCIAIS, Instrução Pastoral $\begin{array}{llll}\text { Communio } & \text { et } & \text { Progressio. } & \text { Disponível }\end{array}$ http://www.vatican.va/roman_curia/pontifical_councils/pccs/documents/rc_pc_pccs_doc_230 51971_communio_po.html. Consultado em 15 junho de 2011. 
—. Instrução Pastoral Aetatis Novae. Disponível em http://www.vatican.va/roman_curia/pontifical_councils/pccs/documents/rc_pc_pccs_doc_220 21992_aetatis_po.html. Consultado em 20 de junho de 2011.

—. Ética nas Comunicações Sociais, 2000. Disponível em http://www.vatican.va/roman_curia/pontifical_councils/pccs/documents/rc_pc_pccs_doc_200 00530_ethics-communications_po.html. Consultado em 10 de junho de 2011. 


\section{Portais e sites:}

www.abert.org.br

www.a12.com/radioam

www.celam.org

www.cnbb.org.br

www.comunidade.cancaonova.com

www.ibge.gov.br

www.mc.gov.br

www.mj.gob.br

www.planalto.gov.br

www.radio.cancaonova.com

www.redentoristaspoa.com.br

www.rccbrasil.org.br

www.rcr.org.br

www.vatican.va 


\section{APÊNDICES}

\section{APÊNDICE A}

Entrevista com o padre César Moreira, diretor geral da Rádio e TV Aparecida, realizada no dia 09/07/2011, em São Paulo.

P: Quando a Rádio Aparecida adotou o jornalismo em sua programação e por quê? Nós sabemos que as emissoras comerciais são obrigadas por lei a reservar pelo menos $5 \%$ da programação a conteúdo informativo. Seria essa a razão?

R: A Rádio Aparecida AM faz 60 anos no dia 8 de setembro [de 2011]. Ela tem história. Ela nasceu com um grupo de padres, em torno do Santuário, mas também com um grupo de leigos, e a idéia deles era copiar a Rádio Nacional, do Rio de Janeiro. Tudo o que a Rádio Nacional tinha eles foram copiando na Rádio Aparecida. Por exemplo, novelas, radionovelas, a Rádio Aparecida fez muito, shows, programas de auditório, e o jornalismo também. Só que eles começaram o jornalismo com o esporte, para a garotada, mas depois isso foi se sedimentando e, em 1958... eu tenho uma monografia que conta essa história, abordando o jornalismo evangelizador.

Então, a partir de 1958 surgiu o jornalismo. Eles colocaram dois ou três jornais, havia uma edição regional e tal, mas o jornalismo tornou-se mais forte nos anos 80, quando eu assumi a rádio, porque eu era jornalista formado, eu fiz faculdade de Jornalismo, eu era jornalista profissional, então eu cheguei lá, claro, mudei o jornalismo, adotei outra visão e fiz o jornalismo ser o que deve ser e fui escrevendo o que o jornalismo deveria ser. Passamos a ter edições maiores. Em 1994, surgiu a Rede Católica de Rádio, tinha uma edição grande de jornalismo, que se chama Jornal Brasil Hoje, que era feita em Goiânia e agora é feita em Aparecida. Então, a tradição de fazer noticiário já existia no começo da Rádio Aparecida. Interessava a nós fazer jornalismo, que era uma leitura crítica da realidade. Sobretudo nos anos 70, com a ditadura, era meio abafado. Quando chegaram os anos 80 e eu estava na rádio, que veio a abertura, então o nosso jornalismo cresceu muito mais. Eu cheguei a ser chamado em Brasília várias vezes por posturas que nós tomávamos, aquela história dos padres franceses, por exemplo. Toda semana nós tínhamos que mandar a gravação do nosso jornal para lá. A censura pediu porque havia situações de comentários que nós fazíamos e eles não gostavam. Então, a gente foi fazendo a história do jornalismo e uma leitura crítica da realidade, seja no tempo da ditadura, seja de 80 para frente, quando eu cheguei lá e, mais tarde, de 85 para frente, quando vieram as Diretas Já, então foi uma distensão maior.

Essa é a história: interessava à Rádio Aparecida fazer jornalismo, porque o jornalismo era uma leitura crítica da realidade. Eu depois fiz uma tese (sic) dizendo que o jornalismo 
também é evangelização. Eu cheguei a juntar mil opiniões de ouvintes e essas opiniões valeram na minha monografia.

P: Qual a importância do jornalismo na programação?

R: É uma forma de evangelização. Para nós, evangelização também se faz via jornalismo, como uma leitura crítica da realidade, formação de opinião, exercício de cidadania, tudo isso diz respeito a jornalismo.

P: E vocês seguem alguma diretriz geral da Igreja Católica?

R: O Concílio Vaticano II. Dois documentos básicos: Gaudium et Spes e Lumen Gentius. Um fala da realidade divina e outro, da realidade humana, ou seja, um olha de cima para baixo e outro olha de baixo para cima. Esses dois documentos formam o cerne da nossa evangelização. Então, nós não estamos chutando. Estamos falando o que o concílio fala, nada mais do que isso.

P: E essa forma evangelização seria passar os valores que estão nesses documentos?

R: Na programação toda, não só no jornalismo. Ela é um todo. Então nós passamos esses valores através de música, fazemos uma leitura crítica das músicas, passamos valores através de prestação de serviço. Há uma tradição entre nós, a ponto de hoje, por exemplo, a Rádio Aparecida, na cidade, na região, ter o jornal de maior audiência. Outro dia o prefeito me disse assim: "De 10 rádios ligadas, 9 e meia estão na Rádio Aparecida”. Então a prefeitura quer comprar espaço nessa hora para divulgar as coisas dela. Há uma credibilidade em torno da rádio, principalmente a partir de 80 e pouco, quando a rádio ficou mais agressiva. Quando o Collor ganhou a eleição do Lula, fizeram um enterro na cidade, dizendo que eu era PT, que eu malhava o Collor, e malhava com razão, porque depois que ele foi expulso eu que fiz um caixão com a cidade de Aparecida...

P: E quais são os principais jornais da emissora, qual a história desses jornais?

R: Começou com o Jornal Falado. Depois, criei o primeiro Panorama Jornalístico, mais tarde criei o Jornal dos Jornais, que é o que está no ar hoje, com quase 10 mil edições. Depois o da Rede Católica, que ganhou o nome de Jornal Brasil Hoje, de meia hora por dia, desde 94. Esse jornal foi patrocinado durante muito tempo pela Petrobras, mas não tinha nada a ver. Era patrocinado, mas nós falávamos o que nós queríamos. E tem também o Jornal dos Jornais, com duas edições diárias, das $7 \mathrm{~h} 30$ às $8 \mathrm{~h}$ e das $17 \mathrm{~h} 30$ às $18 \mathrm{~h}$. Mas, ele chegou a ser das 6 h15 às 8h, por exemplo. Depois, quando surgiu a Rede Católica de Rádio, nós diminuímos porque entrava o Jornal Brasil Hoje.

P: O que é a Rede Católica de Rádio? 
R: A rede católica é uma associação que reúne as emissoras para promovê-las, para comercializar essas emissoras, o cunho dela é financeiro. Ela nasceu em 10 de novembro de 1994. Há uma associação para a radiodifusão católica, que se chama Unda, União de Radiodifusão Católica, da qual fui presidente muito tempo. Da Unda, é que nasceu a Rede Católica de Rádio. Porque a Unda tratava da política de comunicação e as rádioa, mais do que de políticas de comunicação, precisavam de produtos. Então que produtos a Rede Católica de Rádio tem? Nós fizemos uma série de produtos que colocamos à disposição das emissoras. Basta a emissora se filiar à Rede Católica de Rádio, ela preenche uma ficha, assume alguns compromissos, mas não paga dinheiro. E elas foram se afiliando. Então, o Jornal Brasil Hoje, à medida que as rádios se afiliavam, nós vendíamos para a Petrobras e pagávamos o dinheiro para as rádios. Então, a rádio ganhava o jornal e também ganhava dinheiro pela propaganda que ela fazia. Era uma forma de redimir as rádios, de melhorar a qualidade das rádios. Porque não adiantava nós termos 200 rádios, mas todas caindo pelas tabelas. Tinha que melhorar essas rádios. Então, a Rede Católica de Rádio é uma associação criada pelas rádios mais fortes, que são cabeças, para oferecer programação para as rádios menores. Como o jornalismo. Ninguém pode ter um jornalismo nacional. É caro ter repórter em Brasília, repórter em São Paulo, então essas coisas todas as rede fez. Ou nós vendíamos ou as rádios grandes patrocinavam, bancavam os jornais. A Rede Católica, por exemplo, ainda vende propagandas para o governo e reparte o dinheiro entre as emissoras.

Os outros jornais, cada emissora tem o seu. Então, quando eu falo Jornal dos Jornais é Rádio Aparecida. A Rádio Aparecida hoje tem: Brasil Hoje, Jornal dos Jornais, que tem uma edição de manhã e uma edição à tarde. Esses são nacionais e mais o Jornal Regional.

\section{P: A Rádio Aparecida tem alcance nacional?}

R: Sim, porque ela tem ondas curtas, estamos no Brasil inteiro. Então, quando é jornalismo, junta as emissoras de ondas curtas, ondas médias e frequência modulada.

P: E qual o maior desafio de falar para um público tão diversificado?

R: Porque hoje o público se fez... o público da Rádio Aparecida sempre foi um público crítico. A Rádio Aparecida sempre assumiu uma atitude crítica. No começo da rádio, o padre Vitor [Coelho de Almeida, missionário redentorista e um dos fundadores da Rádio Aparecida], lá em mil novecentos e nada, a rádio foi fechada, porque ele falou de direitos humanos, ele leu a Declaração de Direitos Humanos e acharam que a rádio estava ofendendo o governo. Então, nós já temos tradição de fazer a análise da realidade. Nós fazemos uma evangelização que é real, daí a diferença com a Canção Nova. A Canção Nova fica em torno de Deus. Nós fazemos de baixo para cima e não de cima para baixo. Então, nós não rezamos muito, nós não temos língua para falar, é só o português mesmo... essas firulas da religião não têm nada a ver conosco. Nosso negócio é a transformação da pessoa humana, esse é que é o negócio. A linha da Rádio Aparecida é valorizar o humano, defender tudo o que é humano, porque o humano é a forma de chegar ao divino. E o jornalismo passa por isso, valores 
humanos, colocar o sujeito de pé, brigar as brigas que ele precisa, lutar pelos interesses, pelos direitos que ele tem.

P: E o jornal sempre teve editorial?

R: Sempre teve. Nós fazemos questão do editorial, porque é uma forma de colocar a opinião da gente. Tem um livro meu, nem fui eu que fiz, fizeram para mim, com os meus comentários sobre o governo Lula, de 2002 a 2005, se chama Assunto do Dia. Um grupo de jornalistas se reuniu e escolheu os melhores comentários e fizeram o livro com os meus comentários. Eu faço um comentário por dia. Vai ao ar no Brasil Hoje e depois no Jornal dos Jornais.

P: Qual é a linha editorial adotada pela rádio? Que tipo de notícias vocês selecionam? Como é a pauta, o agendamento?

R: Primeiro, as notícias do dia, o que for notícia do dia. Mas nem tudo o que for notícia do dia nos interessa. Por exemplo, violência não nos interessa, exploração nenhuma. Sobretudo a área econômica e política. Depois, notícias que interessam ao maior número de pessoas, sobretudo às do andar de baixo, então a coisa mais popular, direitos das pessoas, cidadania. Notícias do dia, sobretudo política e economia, questões que interessam ao maior número de pessoas, e aquelas teses que a Igreja defende, as questões dos movimentos, a questão da terra, das pastorais, do índio, essas brigas a gente compra. Um pouquinho de internacional, sobretudo destaque para a América Latina. Então, basicamente, é por aí que passa a nossa conversa.

Eu fiquei cinco anos fora da rádio e voltei agora. Quando chegou a TV, em 2005, eu saí e voltei a assumir a rádio e criei esses dias o Jornal dos Jornais de manhã cedo, que tinham tirado, eu voltei com a edição. Agora, eu mudei de novo e nós estamos fazendo o Jornal dos Jornais, das 7 h30 às 8h, uma edição opinativa. No jornal da tarde, são as notícias que vão aparecer amanhã. De manhã, é totalmente opinativo. Por exemplo, caiu o ministro dos Transportes, a gente ouve diferentes opiniões sobre o assunto. Então, das $7 \mathrm{~h}$ às 7h30, o Brasil Hoje é informativo e opinativo; das 7 h30 às 8h, o Jornal dos Jornais também é fortemente opinativo.

P: E com relação às notícias da Igreja Católica. Vocês dão notícias da Igreja Católica no Brasil e no mundo? Ou não?

R: Sim, a gente dá um pouco de notícia do Vaticano, mas não é o que mais nos interessa. O que nos interessa é mais de fundo social. O que diz respeito ao religioso geralmente a gente não dá. Em relação à Igreja, o que é de fundo social. Essas notícias de que vai ter missa não sei onde, procissão, a gente não perde tempo com isso. Nada que é paroquial nos diz respeito. Claro que um ou outro programa divulga uma festa religiosa, mas no jornalismo não. $\mathrm{O}$ jornalismo é só o que possa mexer com a vida das pessoas. Se não tiver repercussão na vida das pessoas a gente não fala. 
P: Vocês recebem notícias de correspondentes, de repórteres?

R: Sim, nós temos correspondente em Brasília, São Paulo, sempre tivemos. Com a Rede Católica de Rádio, há correspondentes deles em outros lugares, no Norte, no Sul, nos principais pontos.

P: Vocês têm redação em outros lugares?

R: Não precisa. Hoje o repórter é a redação. Esses repórteres estão conosco há 15 ou 20 anos já.

P: Normalmente, vocês sempre procuram repercutir com alguém e dão uma tratada na notícia?

R: Sim, normalmente damos uma tratada, até porque, até porque, quando o sujeito vai comentar a notícia, ele está dando uma opinião. Pode não ser a melhor, mas é uma opinião. Então, temos um jornal opinativo. Nós não brigamos tanto pelo factual, nós procuramos reforçar pelo opinativo. Caiu o avião, então a gente dá a notícia e ponto. Não vamos ficar repetindo essa notícia.

P: E por que esse foco no opinativo?

R: Porque ele é que forma a consciência nas pessoas ajuda a pessoa a desconfiar. Por isso é que eu tenho mil cartinhas, com a opinião de ouvinte. O ouvinte dá a opinião dele, às vezes concorda, às vezes não concorda.

P: Aliás, a gente observa que a rádio tem uma grande interatividade com o ouvinte. Como são esses canais de interatividade? O público dá uma diretriz, de alguma forma ele influencia no jornalismo?

R: Ele oferece pautas. A opinião do ouvinte é para multiplicar. Inclusive a gente incentiva: "Essa é a minha opinião, mas se a sua for diferente, então diz qual é a sua”. Na minha monografia, eu juntei uma quantidade enorme de opiniões de ouvintes, cito várias opiniões de ouvintes. Porque eu sabia que eu iria fazer um estudo sobre isso um dia. Sobre a diferenciação das opiniões.

P: E como são esses canais de interatividade?

R: Hoje a maioria tem internet, que á mais fácil, mas também é telefone, é carta, de todas as formas que possa participar.

P: Tem algum caminho que vocês queiram seguir no jornalismo? O que vocês ainda acham que precisam melhorar no jornalismo de vocês?

R: O jornalismo está sempre aberto a mudanças e precisa ser, porque é a interpretação dos fatos e procurar atender o ouvinte. O que nós estamos reforçando agora é a internet, é por aí que a coisa vai andar. O rádio já vai para a internet, a webrádio. Então a gente se preocupa 
muito com isso, inclusive abordamos temas que dizem respeito à própria internet, questão de legislação, de liberdade, é procurar seguir a coisa do momento. E a nossa programação, o nosso jornalismo, de onda média, que é local, é prestação de serviço. A gente pergunta para o ouvinte: "O que você precisa? Diz pra gente qual a dificuldade você tem no seu distrito. Diz pra gente que nós vamos atrás. O que não funciona no seu bairro? Conta pra gente que a gente corre atrás”. Isso é a onda média, o local, o jornal local. Então, esse jornal passa a ser o centro das reclamações regionais. Nós fizemos na nossa rádio um programa, ouvindo as partes como deveria ser. Então, nós damos muito mais audiência que as rádios locais. As rádio locais, coitadas, a prefeitura compra lá, e acaba sendo a principal patrocinadora deles. Como é que eles vão brigar? Tanto que o Jornal Regional, as prefeituras gravam. Eu mesmo falo assim: "Vocês gravam para ver as dificuldades e até se quiserem entrar na Justiça contra nós, vocês já têm a gravação. Aproveita e grava” (risos).

P: E esses canais vocês estão ampliando, estão investindo na internet?

R: Hoje não interessa mais ter emissora de rádio, interessa ter outras formas de relacionamento. Daqui a pouco, o computador vai ser tudo, não é? Mas o nosso jornalismo, como tem tradição, nós fazemos um jornalismo muito bom, tanto no rádio quanto na televisão. A equipe até já sabe o que eu quero e o que saiu errado na edição. Não precisa falar nada. "Nós erramos nisso, nisso e naquilo”. Então eu digo: "Vocês já sabem como tem que fazer amanhã”. 


\section{APÊNDICE B}

Entrevista com Ederson Santos, editor-chefe da Rádio Aparecida, realizada no dia 4 de agosto de 2011, em Aparecida (SP).

\section{P: Seu nome completo e cargo?}

R: Ederson Francisco dos Santos, sou editor-chefe de Jornalismo da Rádio Aparecida. Assino como Ederson Santos.

P: Você pode dar um breve currículo seu?

R: Sou formado em Jornalismo na Fatea, a Faculdade Teresa D’Ávila, aqui de Lorena, e fiz Ciência Política na USP, em São Paulo. Na realidade, sou formado em Jornalismo há pouco tempo, há quatro anos mas, na Rádio Aparecida, a gente tem uma maneira diferente de trabalhar sobre vários aspectos. Tão importante quanto conhecer a profissão que você vai exercer, seja radialista, jornalista, produtor, seja ela qual for, é importante conhecer a filosofia da empresa. E eu trabalho aqui na empresa há quase 15 anos, só trabalhei aqui. Comecei como guardinha, depois trabalhei no Clube dos Sócios, daí como operador de áudio, depois fiz locução, jornalismo e depois cheguei a ser editor-chefe por indicação do padre César, mesmo com pouco tempo de jornalismo, mas por conhecer a filosofia da empresa.

P: Você tem voz de locutor. A gente até pensa que você foi para locução por causa da voz.

R: Na realidade, o trabalho aqui é um trabalho bem profissional até, por conta agora da TV, a gente conta com um trabalho de fono, que serve tanto para rádio quanto para a TV. Uma das condições que a gente coloca para as pessoas que trabalham aqui é que procurem melhorar em todos os aspectos, mesmo que sejam cursos rápidos, como curso de locução, a gente procura fazer aula com fonoaudióloga, até para manter a qualidade do padrão que é estipulado pelo próprio diretor geral da rádio, o padre César, que é bastante exigente.

P: Com funciona o Clube dos Sócios?

R: Funciona da seguinte forma: a renda que a rádio tem para sobreviver vem através do Departamento Comercial, nós somos uma rádio comercial, que vende propaganda, assim com a maioria das outras. Mas nós temos uma filosofia, que é a prestação de serviço o tempo todo. É um compromisso. E o Clube dos Sócios é o outro pilar, o comercial e o Clube dos Sócios. São as pessoas que se identificam com a Rádio Aparecida. É interessante, a gente ouve as pessoas dizerem: “Eduquei meu filho ouvindo a Rádio Aparecida”. Então, são dicas de saúde, do Departamento de Jornalismo, são dicas e informações que vão contribuindo para o dia a 
dia da pessoa. E as pessoas ajudam espontaneamente. É diferente, por exemplo, do sistema de outros lugares, que a pessoa tem a obrigação de pagar um valor determinado em cada data; aqui é uma vez por ano, é livre e espontâneo Se a pessoa puder, vai contribuindo da forma que quiser, o importante é estar em comunhão com a Rádio Aparecida.

P: A maioria das pessoas que fazem parte do Clube dos Sócios é da região?

R: Não, a maioria absoluta é de outros estados, a maioria absoluta é do Espírito Santo e Minas, sobretudo.

P: Você pode fazer doações e se tornar sócio pela internet?

R: Pode. Acessando a página da Rádio Aparecida. Na realidade é o portal, temos o portal, que envolve a rádio, a TV, a Editora Santuário e os redentoristas. Acessando o portal, que é o www.a12.com, você tem o link separado para acessar a rádio, a TV e, dentro do site da rádio, você encontra as informações do Clube dos Sócios, como se cadastratar. É interessante porque são pessoas do Brasil todo.

P: O jornalismo na rádio é uma tradição. A rádio praticamente sempre teve jornalismo. Atualmente, quanto da programação é jornalismo? Quantos programas jornalísticos vocês têm?

R: O departamento que mais produz na Rádio Aparecida, é o de jornalismo. O padre César sempre diz que na Rádio Aparecida tem que ser o carro-chefe, 24 horas. Então, vou falar, passo a passo, o que temos de jornalismo aqui na Rádio Aparecida. Como eu disse, a Rádio Aparecida é como se fosse três em uma: temos a Rádio Aparecida Ondas Curtas, para o Brasil todo, temos a Rádio Aparecida FM, regional, a Rádio Aparecida AM, que também é regional, onde também colocamos ondas tropicais para ter um alcance um pouco maior.

P: O alcance maior é das ondas curtas?

R: Isso. As ondas curtas, que pegam o Brasil todo. A FM, que é regional, e a AM, que também é regional. E nós temos a RCR, a Rede Católica de Rádio. O jornalismo produz conteúdos para a RCR, ondas curtas FM e AM.

P: Na FM tem jornalismo, tem os mesmos programas?

R: Não, não são os mesmos programas. São programas distintos para ondas diversas. Por exemplo, começando o dia, nós temos, a partir das 7 horas, o Jornal Brasil Hoje, de meia hora; é um programa jornalístico, produzido pela Rede Aparecida, apresentado aqui e retransmitido pelas emissoras da Rede Católica de Rádio; são mais de 100 emissoras que retransmitem esse jornal [segundo dados atualizados da RCR, são mais de 200 emissoras atualmente que fazem parte da rede]; vai para ondas médias, ondas curtas e via satélite, para a gente distribuir para outras emissoras. Nós temos o Jornal dos Jornais $1^{a}$ Edição, que começa logo na sequência, a partir das 7h30, e é um jornal que vai para AM, ondas médias e ondas curtas, e nós deixamos disponível também via satélite para as emissoras que tiverem interesse 
colocarem no ar, mas é um produto que fazemos para a Rádio Aparecida. Temos informações que algumas emissoras transmitem também. Às 11 horas, temos o terceiro jornal, o Jornal Regional, que é um dos programas mais tradicionais, mais ouvidos, seguramente o de maior audiência aqui na região do Vale do Paraíba, começa às 11 horas e termina ao meio-dia. Depois, temos também um programa de esportes que classificamos como jornalístico, porque esporte faz parte do pacote de informações que as pessoas buscam todos os dias nos meios de comunicação. Esse programa é das $17 \mathrm{~h}$ às $17 \mathrm{~h} 30$, em ondas médias. Depois, das $17 \mathrm{~h} 30$ às 18h, temos o Jornal dos Jornais $2^{a}$ Edição. Esse programa já vai para ondas médias, ondas curtas e também via satélite. Esses são nossos quatro momentos principais. Temos também o Plantão $R C R$, que entra faltando cinco minutos para uma hora cheia, de manhã e no período da tarde; às 8:55, 9:55 e 10:55, três no período da manhã e, no período da tarde, temos 1:55, 2:55, 3:55 e 4:55. São os plantões da rede. Nós fazemos aqui e, nesse momento, as emissoras que estão na rede transmitem nossa programação daqui também. São os produtos principais que nós temos. Agora, claro, entre um jornal e outro, temos uma série de boletins, que a gente produz tanto para AM, FM e ondas curtas.

P: Como é cada jornal, qual a característica de cada um?

R: Vou começar pelo Jornal Brasil Hoje. Características: primeiro, é apresentado pelo Marcelo Ramiro e pela Carolina Barros. Os dois são jornalistas. Para trabalhar com a gente tem que ser jornalista, tem que ter sentado no banco da faculdade. Eles apresentam, a redação é feita pelo Gustavo Almada, as reportagens são feitas pela equipe de jornalismo da Rádio Aparecida e nós recebemos boletins diários de várias rádios que pertencem à Rede Católica de Rádio.

\section{R: Quantas são colaboradoras?}

P: São mais de 100 rádios na rede [segundo a RCR, atualmente as associadas à rede são mais de 200], mas não são todas que mandam boletins. Tem muita gente que transmite a Rádio Aparecida, mas não tem a mesma estrutura, tem rádio que não tem nem jornalismo. Eles apostam muito no nosso jornalismo daqui. A característica desse programa é informar aquilo que de mais importante acontece no Brasil, mas sob olhar da Rede Católica de Rádio. Nós somos assumidamente uma emissora católica. Então, temos algumas coisas que a gente não coloca. Por exemplo, não damos espaço para a violência.

P: Quais os temas que vocês priorizam ou não?

R: Violência não, apesar de dar muita audiência, mas não faz parte. Se a gente quer educar as pessoas para a cidadania, então a gente precisa separar as coisas. Não pode também passar a ideia de que no Brasil está tudo errado. O que tiver que criticar, claro que nós temos nossos editorialistas, que é o padre Jesus Flores, da Rádio Difusora, de Goiânia, e o padre César Moreira, nosso diretor geral da Rádio e TV Aparecida. É um jornal informativo. É importante termos informações de várias partes do Brasil, para dar essa conotação de nacional. Às vezes, tem que ter notícias que são um tanto quanto regionais, que não interessam tanto para o 
âmbito nacional, mas é importante para aquela região que está acompanhando a programação da Rádio Aparecida, aquele estado que não tem tanta importância do ponto de vista econômico, mas a gente faz questão de colocar. É um jornal informativo, mas tem também opinião, nos editoriais. Agora, o Jornal dos Jornais $1^{a}$ Edição, que vem logo na sequência. Ele é apresentado por mim e a redação dele também é feita por nosso redator, Gustavo Almada, e as reportagens são todas produzidas pelo Departamento de Jornalismo da Rádio Aparecida. Aí, a gente muda um pouquinho a conotação. A gente pode até dar uma notícia parecida, que foi dada no jornal anterior, mas a gente tenta analisar um pouco mais, saber o que isso vai influenciar na vida da população. Aí, nós contamos com nossos especialistas, de algumas áreas que a gente acha interessante. São especialistas que não pertencem ao quadro de funcionários. A gente acha interessante ter porque é uma troca. É importante para eles ter um espaço para colocar o posicionamento, eles ficam mais conhecidos, usam a mídia para isso, para reconhecimento, e a gente tem a possibilidade de contar com a opinião desses profissionais, pessoas que realmente entendem do assunto. Então, nós temos um especialista na área de Economia, que entra duas vezes por semana, um especialista na área de Política, também duas vezes por semana, um especialista na área de Meio Ambiente - fazemos questão de ter um especialista nessa área até por conta do tema da Campanha da Fraternidade. Precisamos bater nessa tecla, se não cai no esquecimento. Temos um especialista em Saúde, temos um especialista em Previdência Social e também em Educação. Então, é um jornal de prestação de serviço e análise dos fatos.

Jornal Regional, que vai para FM e AM. É um jornal, em que nós fizemos uma experiência. Nós mudamos um pouco a linguagem do jornal, tanto dos repórteres quanto do apresentador, que sou eu. Porque o nosso jornal é no horário do almoço, a gente fala muito para as donas de casa, então tem que ser um jornal leve. Não adianta eu impostar a voz, porque as pessoas estão naquele momento de relaxar. Tem que ser próximo, a gente procura se aproximar das famílias. Então, a gente usa bastante aquela linguagem do "você". A gente abre espaço para a participação do ouvinte e ligam muitas e muitas pessoas, a gente não coloca todas porque não tem condições. As pessoas ligam, participam pelo e-mail, pelas redes sociais, Facebook, Twitter. Eles colocam lá seus comentários. Claro que nós tomamos cuidado com os comentários, questão de apuração; e a linguagem é mais próxima do povo e as notícias também. O jornal procura questionar também. Noventa por cento das pautas que nós temos no Jornal Regional são provenientes de observação dos nossos ouvintes. A gente insiste a toda hora: "Participe com a gente”. E a gente fala exatamente aquilo que o povo quer ouvir. Então, não é o que a gente acha interessante, o jornal é feito basicamente para aquilo que o povo quer ouvir. É um jornal feito de segunda a sexta-feira; é um produto no horário mais vantajoso financeiramente para a emissora, é o que mais vende e é o de maior audiência aqui na região do Vale do Paraíba, transmitido em AM e FM. Ele é transmitido em cadeia. São rádios regionais. A potência da AM é muito boa. E da FM também. Então pega em toda a região do Vale do Paraíba e até no Sul de Minas.

P: E como se dá essa participação dos ouvintes por telefone? Vocês colocam os ouvintes direto em contato com vocês? 
R: Nós não colocamos em contato direto no ar, porque, primeiramente, nós somos muito preocupados com a qualidade do áudio, se o ouvinte vai entrar, vai ser por telefone. $\mathrm{O}$ telefone pode dar algum problema no ar. A gente não sabe se, no calor da denúncia, o ouvinte vai dizer alguma coisa que não deve, alguma palavra que não pode no ar. E, se a gente cortar no ar, vai ficar mais feio ainda. Então, o procedimento é o seguinte: nós trabalhamos, sim, colocando o ouvinte no ar, mas todos são gravados. A gente checa a veracidade da informação primeiro e verifica se a pessoa tem uma fluência, se ela consegue expressar aquilo que ela falou para a gente. Porque, às vezes, a pessoa fala para você uma coisa e depois, quando está gravando, ela não consegue repetir. Então a gente pede: “Olha, infelizmente, não ficou compreensível. Dá para você tentar de novo?” Se não der, a gente não coloca. É natural, a pessoa fica nervosa. E, aí, a gente grava, porque, todo mundo que a gente coloca no ar para falar, precisa dar a resposta. O pessoal da produção corre atrás da resposta durante a tarde e colocamos no dia seguinte em forma de matéria ou em forma de texto explicando o que tem que fazer para resolver o problema daquela pessoa.

P: Em geral, são denúncias, reivindicações?

R: A maioria é de reivindicações, as mais diversas. Lembrando que o primeiro critério para a gente definir a inclusão da opinião do ouvinte - a gente insiste com isso no ar - é problema que afeta a coletividade. Não é um problema particular. Então, a gente analisa. Se a pessoa relata um problema particular, de infiltração em sua casa, aparentemente é um problema só dela. Mas, se a gente percebe que é um problema estrutural, se é um problema de lixo que está atrapalhando a rua, causando enchente, então é mais relevante.

P: Qual é a filosofia de trabalho de vocês? Qual é a linha editorial e quais temas vocês priorizam ou que não abordam? O jornalismo na Rádio Aparecida pode ser considerado evangelizador?

R: Nós seguimos à risca a filosofia que foi implantada pelo padre César, até pela experiência que ele tem, em rádio, mas também porque acreditamos naquilo que ele fala. Então, nós temos uma linha de evangelização, que é a seguinte: valorizar o ser humano, em busca do divino. Então, na evangelização, a gente não pode limitar a programação no relacionamento meu com Deus, senão a programação seria isso o dia inteiro. E o próprio jornal seria piedoso. Então, é enxergar Deus no próximo. E não tem tabu. O próximo tema que o padre César vai tratar no editorial é o homossexualismo, mas o tema é abordado de maneira plural. A Igreja tem tal pensamento sobre o tema, mas, se você não concorda, pode ligar e dar a sua opinião. E nós lemos todas. Outro dia nós fizemos um debate sobre a legalização da droga e quem é favorável, lógico, a gente abre espaço. Então, essa é a filosofia nossa. É valorizar o ser humano, em busca do divino. E o que quer dizer isso? Nós entendemos que a evangelização não acontece somente no sermão. Claro que, também no sermão. Mas acontece diariamente. Em busca da cidadania. O nosso maior desafio é fazer com que o povo brasileiro seja cada vez mais cidadão. Porque, se o povo brasileiro fosse cidadão, se participasse mais ativamente da vida política, se todo mundo se preocupasse com isso, a gente teria uma cidade, um estado, 
um país, um mundo melhor. Então, a nossa filosofia é justamente despertar para o senso de cidadania. E, claro, prestação de serviço, que é obrigação de toda rádio fazer.

P: E as linhas editoriais dos jornais seguem as editorias tradicionais do jornalismo, como Economia, Política, incluindo Meio Ambiente também? Como vocês selecionam as notícias?

R: As notícias estão sempre de acordo com a nossa filosofia. Então, se nós temos a filosofia de despertar par a cidadania, nós temos que tratar de tudo, tudo que está sendo tratado que é relevante. Então, os principais assuntos de Política, Economia, mas, lógico, eu até brinco com a equipe: “Eu não quero que as notícias sejam dadas só porque está na internet”. É uma soma de conhecimentos. Para você montar um texto tem que ler os principais jornais, O Estado de S. Paulo, a Folha de S. Paulo, O Globo, os editoriais. Então, quando você vai fazer a redação, você tem condição de lembrar de todas as questões importantes envolvendo a notícia. Não está no texto, mas tem questões anteriores, da semana passada que explicam o que está acontecendo agora. $\mathrm{E}$ a gente seleciona, primeiro, com as agências de notícias, como todas as emissoras fazem, lembrando que só temos uma restrição em relação a assuntos que não vão acrescentar muito, como a violência. Porque não resolve. Em jornalismo não adianta tratar só do problema, tem que tratar da problemática. A gente discutiu isso na Costa Rica [no Congresso de Rádios Católicas da América Latina, realizado em novembro de 2010, em San José], do último fórum de que eu participei. A imprensa, de forma geral, discute o problema. Mas a problemática é muito maior. Se mataram uma pessoa, tem que perguntar o que ocasionou isso, o que levou a isso. Aí, você vê, por exemplo, que a pessoa está envolvida com drogas. Então, tem que discutir o que está por trás. Não adianta ficar massacrando o assunto, a TV tem mania de fazer isso, mostrando as imagens. É a problemática que tem que discutir. Então, o que interessa para nós é a raiz do fato. Tem um fato, então nós vamos buscar a raiz do problema. Por exemplo, outro dia aconteceu um atropelamento em frente à rádio. A gente não trabalha com imediatismo. O imediatismo não funciona para nós. A gente noticiou como boletim, você tem que noticiar, então demos a notícia como boletim. No jornal a gente vai aprofundar um pouco mais: "Por que aconteceu isso?” As pessoas ficam em geral restritas ao fato, mas por que aconteceu isso? Porque está mal sinalizado, porque os motoristas não respeitam. Então, vamos procurar a causa, se existe uma campanha de orientação para os pedestres, ou para os motoristas, vamos procurar a Polícia Rodoviária Federal, que é responsável pela rodovia, para saber por que não há uma fiscalização ali, por que aquele trevo está aberto, sendo que é perigoso. Então, a gente trabalha dessa maneira. E abordamos os mais diferentes temas.

As notícias internacionais, em geral a gente dá mais no Jornal dos Jornais, que é um jornal mais de análise. Porque a notícia internacional, se você simplesmente der, ninguém entende o que aconteceu, o que tem a ver com a gente. Ontem, por exemplo, nós fizemos isso. Nosso comentarista Antônio José de Castro falou com a gente sobre essa crise nos Estados Unidos. Ele explicou direitinho o que vai nos influenciar. Isso é que é importante as pessoas entenderem. Não adianta ficar falando em “commodities”. Fica até bonito o jornal (risos), entra um correspondente nos Estados Unidos e tal, mas nós moramos aqui no Brasil. Então, é 
importante saber o que isso vai repercutir aqui. Por exemplo, aconteceu agora na Síria aquele extermínio de civis. A gente dá a notícia, mas tem outras coisas por trás, que o governo estava apoiando o ditador. Então, você pode traçar um paralelo com outros governos e governantes, até com o que acontece aqui. Também não é formatar a opinião do ouvinte. É dar a informação para que ele mesmo forme a sua.

P: Para fechar essa questão da violência. Por exemplo, em um caso como o massacre na escola de Realengo, no Rio. Não tem como não dar uma notícia dessas.

R: Nós demos a notícia. Mas, muitos jornais foram para a porta da escola e criaram um circo. A gente dá a informação e vamos ouvir os analistas para saber por que uma coisa dessas acontece e a gente toma cuidado para, na medida do possível, dar sequência aos assuntos. Por que a mídia, enquanto o assunto rende audiência, você vai indo. Mas, depois, o assunto começa a ficar chato e aí ninguém fala mais nada. Então, a gente continua falando daquele problema, mas abordando outros aspectos dele, a maneira como são os nossos jovens, os comportamentos deles, trazemos especialistas em comportamento para podermos entender como é o nosso jovem de hoje. Trouxemos a polícia no dia do debate para discutir a questão das drogas, que também faz com que aumente a violência. Então, a gente continua tratando desses assuntos, mas sem sensacionalismo.

P: Os especialistas comentaristas são daqui da região? São ligados a instituições daqui?

R: Temos alguns aqui da região, porque fica mais fácil de eles virem aqui conversar com a gente, mas temos também de São Paulo. Normalmente eles gravam, ou participam ao vivo, por telefone. Mas consultamos especialistas de todo o Brasil. E não precisam, necessariamente, fazer parte desse quadro. Procuramos as mais diversas opiniões, de ONGs, de outras instituições. Vai do momento.

P: E as notícias sobre a Igreja Católica, o Vaticano e a Igreja no Brasil. Vocês priorizam, tem em todos os jornais, em quais jornais?

R: O Jornal Brasil Hoje nós dividimos basicamente em três editorias: Economia, Política e Informações Gerais. Tudo o que é Tecnologia, Meio Ambiente, entra aqui. Porque não tem tantas notícias assim. Tem que ter um bloco para falar só de Economia, porque é muita coisa, outro para falar de Política, e depois a gente engloba as editoriais em um bloco só. Nesse bloco, entram notícias da Igreja. Você vê que não tem preferência. Se a gente tiver que derrubar uma pauta de Economia ou sobre a Igreja, a gente derruba a da Igreja. Notícia da Igreja entra frequentemente, mas não entra necessariamente em todas as edições. No Jornal Brasil Hoje, a gente dá, no terceiro bloco, notícias direto do Vaticano, com o Silvonei José, que traz os destaques do Vaticano, mas só se for algum assunto relevante. Depois, tem o editorial, no final, que é a palavra da Igreja. O editorial não aborda necessariamente um assunto sobre a Igreja, mas ali o editorial é sempre feito por um padre, o padre Jesus Flores, da Rádio Difusora, de Goiânia, ou o padre César Moreira, da Rádio Aparecida. Em geral, os assuntos são abordados de forma bem isenta. 
Tem gente que quer que a gente faça sermão na hora do comentário, tudo baseado no Evangelho, mas nós temos uma leitura mais ampla do Evangelho. Porque esses assuntos dos editorias precisam ser abordados e muitas pessoas reclamam por nós criticarmos o governo: “Ao invés de vocês fazerem isso, vocês deveriam explicar o Evangelho para o povo, que Deus vai cobrar, vai castigar os políticos”. Não, não é que Deus vai castigar os políticos. As pessoas é que têm que votar certo da próxima vez, ter discernimento. Tem que se ajudar, senão não vai. Deus deu discernimento para nós e tem gente que não usa (risos).

P: Qual o tratamento que vocês dão às notícias? Eu pergunto porque, como você mesmo já destacou, muitas vezes as rádios apenas repetem o conteúdo que viram nos jornais ou na Internet, não procuram complementar, enriquecer o noticiário.

R: Eu até entendo por que muitas rádios fazem isso. É porque a realidade das rádios hoje é muito difícil. Se não tiver um nome forte, uma filosofia, uma estrutura bem implantada, fica difícil. Nós aqui temos a vantagem de ter um quadro maior de profissionais. Nós temos uma tradição, que foi implantada pelos diversos jornalistas que passaram por aqui, mas é principalmente uma filosofia implantada pelo padre César, que é jornalista. O padre César trabalhou em grandes emissoras, então ele trouxe para cá tudo o que ele aprendeu.

Mas, com relação ao tratamento das notícias, quando você tem só uma pessoa trabalhando, às vezes não tem como tratar a notícia. E eu acredito que nem toda notícia precisa ser comentada. Tem notícia que precisa simplesmente ser dada. Por exemplo, o resultado da Mega Sena, ou uma campanha de vacinação, o que é importante as pessoas saberem sobre uma campanha de vacinação? Como a campanha contra a paralisia infantil: que as pessoas precisam levar seus filhos para vacinar e que essa é a única forma eficaz de proteger seus filhos e pronto. Mas notícias que costumam causar dupla interpretação, a gente costuma trazer opiniões diferentes. Então, a vacinação não tem que interpretar. Mas, será que a Dilma está fazendo um bom governo? Então, a gente consulta analistas, entrevistados, que dão a opinião ao vivo. A gente procura equilibrar, quando o entrevistado tem uma opinião favorável, com outros que têm pensamentos diferentes, mais críticos. É um desafio muito grande, uma dificuldade imensa tratar a notícia de forma equilibrada. A gente briga com isso todo dia.

P: E com relação ao deslocamento de repórteres para as ruas. Existe essa possibilidade, mesmo com uma equipe pequena?

R: Para o jornalismo regional, nós vamos em todas as cidades, nós temos dois repórteres de rua, que cada dia trazem informações ao vivo de uma cidade da região. Para os jornais nacionais, nós temos dois que são contratados da casa, o Romualdo de Souza, em Brasília, e Arnaldo Pereira, em São Paulo. Então, esses dois nos ajudam, porque é onde as coisas mais importantes acontecem, não desmerecendo os outros estados. E, quando acontece em outros locais, no Rio de Janeiro, por exemplo, nós solicitamos para os repórteres das rádios colaboradoras. Ou, por exemplo, lá do Pará: "Você poderia trazer informações sobre a separação do Pará?” 
P: E quais as maiores dificuldades e desafios de fazer um jornal nacional? Porque o Brasil é muito amplo, diferenciado. Vocês têm alguma preocupação nesse sentido ou algum retorno de falar para uma população tão ampla?

R: O jornal tem esse objetivo mesmo. A Rádio Aparecida, em ondas curtas, pega em todo o Brasil. Esses dias teve até um ouvinte que ligou para dar opinião no Jornal dos Jornais, lá de Pernambuco. Eu até me perguntei: “O que leva um rapaz lá de Pernambuco a ouvir a Rádio Aparecida?”. Até pensei: “Que responsabilidade!” Então, a gente sabe que tem ouvinte, em cada cantinho deste país e o jornal tem que ser mesmo para o Brasil todo.

Nós estamos preparando um encontro com todos os representantes da RCR para a gente tratar só de jornalismo, porque nós achamos que o comprometimento dessas pessoas pode ser um pouco maior. A gente quer falar para eles sobre o que é notícia para o Jornal Brasil Hoje, para a gente ganhar um contexto nacional. Nós já avançamos muito, mas ainda há esse desafio. Nós não conhecemos a estrutura de cada emissora. Às vezes, nós nos deparamos com emissoras que, quando muito, têm um locutor. Essa é que é a realidade. A maioria das rádios tem uma sala, uma pequena recepção e um estúdio. Então, conhecer melhor essa realidade é o nosso desafio no contexto nacional.

P: E falando em desafio. Você acredita que seja possível melhorar o trabalho de vocês? Como você vê isso? Para onde vocês querem se dirigir, quais as perspectivas?

R: Sempre há o que melhorar. Nós temos a intenção de melhorar o Jornal Brasil Hoje, fazer com que de fato ele ganhe esse contexto nacional. Nós já chegamos próximo disso. A gente quer que realmente mais correspondentes, mais emissoras participem, mandem mais material para que a gente tenha mais material, mais informações de todo o Brasil. Isso não quer dizer que a gente não tenha. Sempre que aparece algo importante, nós solicitamos. No Jornal dos Jornais da manhã, ele é bebê ainda, embora a tradição seja antiga.

P: Ele já existe há algum tempo e agora foi reformulado?

R: Não, fazia quase vinte anos que ele estava fora do ar. O Jornal Brasil Hoje entrou no lugar do Jornal dos Jornais. Ele ficou muito tempo fora do ar e voltou agora. Nós temos ele à tarde. Fizemos uma experiência para colocá-lo cedo. Mas a gente precisa melhorá-lo.

P: Ele era à tarde e passou para a manhã, ou ao contrário?

R: Antes, nós tínhamos o Jornal dos Jornais e não tínhamos o Jornal Brasil Hoje. Aí, nós colocamos o Jornal Brasil Hoje e o Jornal dos Jornais saiu da grade de programação. À tarde, sempre teve. Mas, agora, o padre César pediu para colocarmos a primeira edição, de manhã também. Então, nós temos cedo e temos o jornal à tarde.

R: Por que o horário nobre no rádio é de manhã, não?

P: É. O horário nobre é de manhã. Só que, no período da tarde, tem muita gente voltando do serviço. Então, tem muita gente que acompanha nos carros. Então, cedo e à tarde, nós 
consideramos horários nobres. Você pega o pessoal saindo, tomando banho, ligado na hora. Por isso que a gente dá tanto a hora, para o pessoal que acompanha, muita gente que está se aprontando para sair para o trabalho. Então, o pessoal se pauta pelo rádio, fica informado. Mas, são muitos desafios. O padre me colocou para ser o editor, para que o jornal tenha uma postura ainda mais firme, diante dos acontecimentos, sejam eles regionais, nacionais ou internacionais. Talvez eu não tenha tanta experiência, mas eu sou uma pessoa muito próxima dele e a gente percebe que as idéias batem. Então, eu imagino que eu me encaixe nessa filosofia.

O desafio nosso é tornar os nossos jornais menos lidos, porque a gente percebe que, em sua maioria, os jornais de rádio são lidos. Às vezes, a gente até erra, não é o ideal, mas a intenção é tornar os nossos jornais cada vez mais analíticos e mais próximos, com a linguagem mais próxima dos ouvintes.

\section{P: Qual é o grande diferencial da Rádio Aparecida em relação às outras?}

R: O diferencial da rádio são 60 anos fazendo parte da história dos nossos ouvintes. Não são todas as emissoras que podem dizer que têm 60 anos. Quando nós chegamos nesse ponto, e com o fôlego que nós temos, podemos dizer que temos tradição. E a nossa patrona, que te muito forte (risos). Nós temos uma audiência cativa. Nós temos pessoas que não trocam a Rádio Aparecida por nada. Eu às vezes me pergunto: "Por que uma pessoa lá em Pernambuco está ouvindo a rádio, mesmo com as ondas curtas, com um som um pouco chiado. Se bem que hoje tem internet, mas, em ondas curtas, sempre tem as intempéries do tempo, é inevitável; o som pra ele não vai chegar com a mesma qualidade que uma rádio local. Nós temos até políticos e deputados que nós entrevistamos aqui, me fugiu agora o nome do deputado que, às vezes, nós entrevistamos aqui, e todas as vezes, antes de começar a falar, ele manda um abraço para os familiares dele, que acompanham a Rádio Aparecida todos os dias. Então, tem gente que acredita mesmo nessa tradição. Ela não foi construída hoje. Ela começou lá em 1951 e a gente tenta manter os trilhos, atualizando. Ao longo desses 60 anos, o jornalismo sempre foi o carro-chefe. Então, acho que as pessoas reconhecem a nossa responsabilidade, sobretudo no que diz respeito à participação da vida delas. Nós sabemos que nós interferimos. Nós sabemos que nós temos poder de fazer com que um prefeito seja eleito ou não. Então, as pessoas acreditam na credibilidade da rádio Aparecida. Você sabe que muitas rádios vivem de verbas de prefeituras, vivem de verbas públicas, existem rádios são de políticos, de deputados, o Sarney tem um monte de rádio no Maranhão. Então, cada um utiliza a rádio de uma maneira. Mas, os nossos ouvintes acreditam que a Rádio Aparecida, no caso, os missionários redentoristas, utilizam a rádio para evangelizar de maneira diferente. Há 60 anos se consolidou essa filosofia.

P: As modificações que vocês estão fazendo são em função do aniversário de 60 anos?

R: Essas modificações estão sendo motivadas pela vinda do padre César. O padre César reassumiu a rádio. Ele dirigia a Rádio Aparecida e depois ele ficou um bom tempo em função da TV, para implantar a TV. A TV surgiu da rádio. Então, ela agora começa a caminhar, é um 
bebê ainda, tem cinco anos. Mas, agora, ele voltou para a rádio porque, pela história que ele tem, está buscando ver se está tudo nos trilhos e fazer algumas adequações. São adequações para a gente se atualizar, porque a gente precisa pensar nesse aspecto também. Precisamos ficar atentos ao que o mercado está fazendo. Nós somos tradicionais, mas não podemos ficar de fora daquilo que muda na sociedade. 


\begin{abstract}
APÊNDICE C
Entrevista Antonio Celso Pinelli, gerente comercial da Rádio Aparecida, realizada no dia 4 de agosto de 2011, em Aparecida.

P: Você pode passar um breve currículo seu? Há quanto tempo você trabalha com rádio?

R: Trabalho no rádio há 29 anos. Eu comecei no interior de São Paulo. Quando comecei o gerenciamento, fiz o curso da Fundação Getúlio Vargas, em São Paulo, de Administração e Comunicação em Rádio, na época, não tinha rádio e TV. Fiz curso técnico apenas, não fiz faculdade. Então, comecei em Bauru e fazia um workshop, um laboratório na rádio que eu cuidava para os jornalistas que estavam começando. Então, a gente fazia externa. Naquela época, não se tinha conhecimento da prática de fazer externa e o rádio é muito interessante, ainda hoje é muito interessante essa mobilidade da unidade móvel e antigamente era novidade. A rádio que tivesse era novidade. Então, a gente levava toda a equipe da faculdade para aprender com a gente. Era uma radiozinha bem pequena, bem pacata. Mas era um modelo que eu levei para sempre comigo, o destaque era a comunidade. Voltado sempre para a comunidade, a formação e informação dos ouvintes, sempre foi esse o intuito da rádio. Dali, eu fui para Santa Catarina, fui ser assessor da Câmara de Vereadores e aí eu dirigi uma rádio AM e FM lá, uma rádio comercial, embora fosse dos capuchinhos, mas era uma rádio comercial e o destaque sempre foi fazer o jornalismo. Naquela época, era o gilette press, assim, porque não tinha muito acesso às informações, a questão da facilidade dos meios de comunicação hoje, que facilitou tanto, né? As redes sociais. Então a gente tinha que ler as notícias, ver na televisão, marcar o que tinha acontecido, anotar as fontes, redigir e passar para os ouvintes também. Isso foi na passagem da década de 80 para 90, quando houve uma virada na tecnologia do rádio e na tecnologia dos meios de comunicação em geral. Depois eu vim para São Paulo.
\end{abstract}

O Sul é muito evoluído em termos de tecnologia, sempre foi. É um padrão muito diferente daqui de São Paulo. Quando você pensa que está bem avançado, chega lá e já ultrapassou, já foi. Então, é um diferencial que tem o sul das outras regiões. E eu aprendi muito no curso de locução e comunicação que eu fiz em Florianópolis. É bem diferenciado do estado de São Paulo. Depois de lá, eu vim para São Paulo e diziam que era um desafio que eu iria ter e cheguei aqui e dei risada, porque já era o café com leite que eu já fazia. Não tinha desafio, evidentemente, tinha apenas que trabalhar. Isso para mim foi bom. Foi uma grande escola também. Fiquei por volta de 13, 14 anos. Fiz a implantação do satélite no Brasil, participei da expansão de rede, da evolução do satélite no Brasil. Depois, fiz parte da União de Radiodifusão Católica do Brasil [Unda Brasil, que em 2010 tornou-se Signis Brasil], fiz a implantação na África, em Moçambique. Estive em Portugal também para falar sobre a importância das redes e fui para Tailândia, França, Itália, vários países, trabalhando nesse 
sentido, sobre a importância do rádio para a paz e hoje eu estava revendo uma matéria sobre a importância de se conscientizar as crianças para um mundo de paz sabendo usar o meio, né? Hoje, são as redes sociais e foi nesse congresso também que eu participei na Tailândia, sobre a formação nos novos meios. Eu falava, ontem, inclusive, uma professora veio aqui e pediu para trazer os alunos. Ela disse: “Estou com uma ideia, posso implantar na minha escola?” Era no curso médio, para implantar um estúdio de rádio na escola, para fazer os alunos se interessarem por rádio. A ideia é essa mesma. É fazer os alunos se interessarem por rádio e saber o quanto o rádio é importante na vida e a mobilidade do rádio. Então, achei interessante, porque é uma forma de você reeducar a juventude a ouvir o rádio. Porque eles hoje estão ligados no i-pod, i-pad. Então eu vou ligar rádio pra quê, se eu tenho tudo pronto? Então a gente tem que trabalhar muito com isso e essa é uma forma.

P: E você veio para cá há dois anos?

R: É, eu estava um pouco cansado dos grandes centros, da capital, $\mathrm{ABC}$, passei por vários assaltos. Aí, me deu vontade de sair para o interior. Então, achei essa porta aberta para que eu viesse mostrar meu trabalho para a Rádio Aparecida. E o padre César, eu convivo com ele desde a década de 80, na Unda Brasil, então ele conhece a seriedade do meu trabalho e a idoneidade que eu tenho.

P: Como está sendo o seu trabalho como diretor geral da rádio?

R: Eu gerencio as emissoras rádio de uma maneira geral, toda a programação, mas participo bastante, por interesse pessoal, do jornalismo. A rádio tem o diretor direto, que é o padre César. O que ele manda tem que ser lei, a gente acompanha para ver se está tudo certo, o que falta, o que não falta. A programação está a cargo também do padre William [Betônio, então diretor de Programação da rádio], que está em contato direto com o padre César. Eu gerencio a parte operacional: o que está saindo, o que está acontecendo, o que deve acontecer, que vem da cabeça pensante e do coração, que são o padre César e o padre William, eles ficam articulando isso. Então a gente tá sempre acompanhando. Eu ouço aqui a FM, ouço a onda curta e o AM também. Fico rodando as três ondas pra ver como está. Assim mesmo, sempre escapa alguma coisa. E tem a madrugada, que tem um momento que eu escuto, que eu acordo para escutar.

P: Qual é a característica da programação da Rádio Aparecida? Qual o diferencial?

R: A Aparecida tem um diferencial, a intenção é levar a informação e a formação. Ela trabalha muito com a parte social, com várias classes de ouvintes. O Grande Vale, que é a onda média, que ela pega todo o Vale do Paraíba, vai até sul do Rio e sul de Minas. Então, temos um público já dirigido para isso, é música, informação e formação. Música de duplo sentido não sai. Nós peneiramos tudo e selecionamos.

P: E tem um determinado estilo que é privilegiado? 
R: Não, é geral. Nós colocamos tudo. Só não colocamos duplo sentido. Também religiosa, mas nós temos um momento para isso, como a Consagração de Nossa Senhora, às três da tarde, temos um momento do meio-dia à uma, que é um programa específico dos redentoristas, temos os programas de missa, a missa de manhã, que abre a participação do ouvinte para intenções de missa. Então, tem esse momento. Fora isso, tem o programa Manhã 820, Tarde Ativa, Sertanejo Bom Demais, que eu participo também. Então, nós tocamos tudo, todo tipo de música, desde que não tenha duplo sentido. Nacional, internacional, sertanejo, o que está no mercado hoje. E a gente participa também da concorrência, do Ibope, né? Temos a FM. A FM é diferenciada. Ela não faz missa. Só tem algumas coisas, assim, uma gotinhas de otimismo, para poder animar um pouco a pessoa, porque atinge todas as classes. Já é uma fatia de mercado, de classe social, ousamos dizer comercial, ela é o carro-chefe de sustentabilidade, o faturamento da FM. A gente volta a atenção para a FM para a questão comercial. Nós temos momentos específicos de reflexão, mas missa não temos lá.

A gente também evangeliza pela informação, pela seriedade da notícia. Porque a evangelização hoje em uma rádio católica não é só rezar a Ave Maria e Pai Nosso. A gente evangeliza através da boa notícia, da informação e da formação dos ouvintes. Porque o padre César sempre fala isso: "Para ser evangelizador, não tem que ficar rezando", ser piegas, vamos dizer assim. Então nós trabalhamos com credibilidade, confiabilidade, temos um trabalho sério. Por isso é que tem bastante chefe aí. É porque nós estamos preocupados com o que vai ao ar. Então, nós temos uma programação baseada no entretenimento, que é a música, o jornalismo e a questão social também. Campanhas também nós fazemos, por exemplo de economia de energia, de água. E não precisamos de governo, não, porque o governo até chegar demora. Nós desenvolvemos campanhas o ano todo, de dengue, febre amarela, a gente mesmo desenvolve a campanha e lança no ar.

E temos as ondas curtas. Ondas curtas compreendem 25 metros, 31, 49 e 60 metros. Então são quatro transmissoras de rádio em ondas curtas. Ela atinge o Brasil inteiro e fora dele. Então, tem um grande potencial. Temos ouvintes em todos os estados brasileiros, ao vivo, conosco. Só pelo feedback, a gente já sabe. Eu fui outro dia fazer uma palestra em São Paulo, falar um pouquinho de ondas curtas, da realidade da Rádio Aparecida e não tinham nem noção do que é isso. E é um grande diferencial nosso, também. E ela, sim, é mais evangelizadora. O pessoal que liga, que participa, pede mais música católica. Pede também saudosismo, músicas internacionais, músicas atuais, mas não coisas muito atuais. Você vê que é faixa acima de 40 anos que está pedindo. A juventude, não. A juventude, pessoal de São Paulo, do Rio de Janeiro, ouve mais pela internet. A gente percebe quem está participando de acordo com a música que pede: “Ah, eu quero Luan Santana”. Aí é jovem, que acessou a internet. Por ser uma rádio que não tem muitos investidores, então nós fizemos o Clube dos Sócios da Rádio Aparecida. Esse clube dos sócios são os beneméritos de todo o Brasil, que se unem para a sustentabilidade da rádio. 


\section{P: São quantos sócios?}

R: Nós chegamos a passar de um milhão. Mas tem bem menos, se dispersou muito, diminuiu muito, não sei o que houve, talvez a falta de um trabalho continuado. Então, hoje é muito importante essa retomada. Mesmo assim, o Clube dos Sócios supera o comercial. Hoje os nossos sócios beneméritos e representantes, têm 70, 80 anos. São representantes do Brasil inteiro, pessoas idosas, que vão de porta em porta arrecadar dinheiro durante seis meses, pedir dinheiro para a Rádio Aparecida. Isso são coisas do padre Vítor [Coelho de Almeida, missionário redentorista, um dos fundadores da Rádio Aparecida], da época dele. Então, a cada seis meses tem um encontro aqui na sede. Isso já é praxe. O último foi em julho, agora deve ser em novembro. Então eles, trazem a sacolinha e fazem o controle, veem quem pagou, quem não pagou. É isso até hoje. O pessoal fala: "Puxa, é tão retrógado, mas não pode ser diferente, com boleto bancário”. A gente tem conta corrente, essas coisas novas, mas ainda tem muita gente que até chegar, tem lugares longínquos, aí no interior, no sertão, que não tem como ele ter acesso; então a pessoa passa coletando e tem confiabilidade, eles trazem aqui pra gente. Reúne, a cada vez, 300, 400 associados e representantes, cada um traz a sua quantia. Isso é desde a década de 50, porque a rádio faz 60 anos agora.

\section{P: E quantos são associados?}

R: Olha, eu não tenho o número exato de associados, mas deve estar em torno de 400, 500 mil. Mas não quer dizer que todos contribuem. Alguns contribuem anualmente, outros semestralmente e poucos são beneméritos, que contribuem mensalmente. Então, não é uma coisa que todos pagam todo mês. Não existe isso porque é uma contribuição espontânea, ninguém sabe quanto cada um paga, então cada um dá um real, dois reais, três reais, você não sabe quanto é. Então, não tem assim uma continuidade nessa arrecadação. Esse trabalho que você faz pela ondas curtas dá resultado, se ele é bom dá resultado, se ele for ruim... Porque, no Vale do Paraíba, aqui, o número de sócios é pequeno, então a AM, não usamos a AM para isso. Usamos mais para trabalho de jornalismo, informação, formação e, sim, destaca o Clube dos Sócios, mas tem poucos associados. Mas mais mesmo é onda curtas, inclusive porque pega no Grande Vale porque o vale também ouve ondas curtas. Então, para ter um trabalho desses, você veja, o público, as ondas curtas, as ondas médias, que é o comercial também, a FM, que fatura um pouco mais num determinado horário, que o sertanejo predomina e que concorremos com Celso Portioli e com outras emissoras aqui do vale. Então, por isso um carro-chefe como a FM ajuda a auto-sustentabilidade das emissoras. Então nós temos esse diferencial.

Emissoras católicas, no Brasil, que eu conheço, que vivem hoje só da providência divina, vamos dizer assim (risos), são a Canção Nova e a Milícia da Imaculada. Essas duas aqui, e a Arca da Aliança, em Brasília. São três que vivem exclusivamente da providência divina, dos associados. Eles conseguem recursos externos, da Itália, da Alemanha, da França, tem algumas coisas assim. Além do quê, tem os associados, o Clube dos Sócios deles. Sei que tem outro nome, lógico, mas tem isso. Eu trabalhei em São Paulo, na Milícia, lá nós tínhamos 
cerca de 120, 150 mil associados. Vinha com a revista mensal, o pessoal recebia a revista e pagava mensalmente uma cota. Mas ficava sem pagar se não recebia a revista. Então tinha esse diferencial.

\section{P: E a Rádio Aparecida, sempre funcionou dessa forma?}

R: Ela sempre teve essa mesclagem, meio a meio, ela nunca foi só de pedir. Ela não pede que você seja associado, mas se, quiser participar do clube dos sócios, está aberto também. Não é que fica lá implorando, pedindo esmola, não é bem isso. A gente faz a programação toda e tem a campanha dos devotos do santuário, que é uma outra coisa, mas é do santuário, para manutenção do santuário nacional. O nosso Clube dos Sócios é para manutenção da Rádio Aparecida.

P: Mas tem alguma dificuldade por ser comercial, restringe de alguma maneira? Direciona?

R: Não porque viemos de uma situação que já era assim. Quando criou-se o Clube dos Sócios, já era comercial. Tinha que ter esses investidores da rádio para poder também ajudar na manutenção. Então não fere nada, uma coisa não fere a outra.

P: E dá para ser independente, fazer uma programação independente?

R: Tranquilamente. A gente volta muita a atenção para o Clube dos Sócios com as ondas curtas porque eles já estão acostumados a ouvir a gente através delas. Então tem patrocinadores, mas é mais medicamentos, mais, assim, a nível nacional, que há interesse de divulgar lá. Mas não fere nada. Vamos supor: se você pegar uma emissora como a Canção Nova. Se você jogar um comercial hoje, o pessoal vai chiar. Se você jogar um comercial, no mínimo 100 pessoas deixam de ajudar. Porque é outra consciência, pensam assim: "Se tem comercial, pra que vou dar dinheiro para eles?”. Então, eles têm consciência disso. Há dificuldade de manutenção? Sim. Muitos padres e bispos estão vendendo emissoras de rádio por aí. Muitos. Eles têm ligado pra mim, perguntando sobre avaliações. Eu aconselho: "Não faça isso". E eles falam: "Mas como é que eu vou viver, o povo não ajuda, é muito pobre”. São “n” rádios, em Tocantins, São Luís do Maranhão, tem "n” rádios aí que estão em situação difícil. E grandes, rádios grandes, porque é difícil conseguir hoje uma concessão, mas é a realidade da Igreja Católica. A Igreja Católica demorou bastante para acordar. Mas hoje tem muitas emissoras, dobraram as emissoras. Eu fui presidente da Unda Brasil, a União de Radiodifusão dois mandatos e eu conheci o Brasil inteiro, a realidade de cada região. Nós vivemos no céu aqui nessa região do vale, em São Paulo, perto do Norte e Nordeste, do que eles passam, né? O comercial lá é por $\mathrm{R} \$ 0,50, \mathrm{R} \$ 1$. Para você conseguir o salário de um operador, você tem que trabalhar mais pra ele que pra você. Então, a dificuldade é muito grande e o consumidor de rádio tá lá. Eles vivem do rádio. Porque o pessoal da roça, do interior, tem lugar que não chegou a televisão. Lá em Santarém, chegou lá a Rádio Acorda, porque eles não têm como comprar pilha. Então, eles fizeram um projeto para a Itália, há um ano e meio, dois anos, eu estive lá, e a Itália mandou para eles 500 emissoras de rádios para entregar aos povos indígenas, comunidades que tem no meio da Amazônia. Então, são rádios 
grandes que não usam pilha e pegam todas as ondas. É o único meio de divertimento e informação que eles têm. Isso tem muito ainda no nosso país, muita, muita gente não conhece. Muitos falam: "Manda uma mala direta, manda e-mail”, mas tem muita gente que não tem acesso. O padre pode ter, o diretor da rádio pode ter, mas o cara que tá lá trabalhando não tem acesso. É restrito o uso dele de e-mail. Aí, o pessoal não acredita em São Paulo. E é verdade. Você manda e-mail e metade não lê, porque não tem acesso a e-mail. Essa é a verdade. $\mathrm{O}$ pessoal tira por base os grandes centros e as grandes regiões, que são ricas. $\mathrm{O}$ Vale do Paraíba é rico. A potencialidade de crescimento aqui é muito grande. O quanto cresceu a Rádio Aparecida e outras também. Mas o Norte e Nordeste. Não vou falar o Sul. O Sul, está bem avançado, Paraná, Santa Catarina e Rio Grande do Sul. Eu conheço todas, a maioria das rádios de lá eu conheço todas, rádios católicas. Então, eles vivem uma dificuldade grande de comunicação.

P: E o jornalismo, dentro da programação da Aparecida, qual a importância dele, quanto ele ocupa de espaço?

R: Ele é tudo. Se pudéssemos ocupar, nós ocuparíamos todos os espaços. Nós somos uma geradora da Rede Católica de Rádio, uma geradora importante dentro do meio. Tem um conceito lá fora muito grande, através da confiabilidade, da credibilidade da informação e da importância das fontes que a gente tem. Não destacamos muito a questão de acidentes de trânsito locais, assim desastres de moto, que é constante aqui. Não colocamos em destaque no jornalismo. Acho que isso não forma a opinião de ninguém. Nós somos uma formadora de opinião. E informar o que está acontecendo no dia a dia ao seu público através do noticiário político, econômico, social, em geral. Mas, esse tipo de coisa, de acidente, não. Quando é um acidente de trânsito, pára tudo, lógico, muitas vítimas, a gente transmite, mas coisas corriqueiras não fazemos, proselitismo e essas coisas, não. E agora criamos um jornal novo, aumentou mais meia hora de manhã. E vamos aumentar também para a FM, de forma a não ferir a programação.

\section{P: A FM não tem jornalismo?}

R: Tem, das 11h ao meio-dia, o Jornal dos Jornais. E os boletins. Mas, esse jornal da manhã não temos, não. Nós temos cuidado em não ferir os ouvintes. Se você está bem, está, aí, há dois anos sem mexer. Se você vai tirar essa hora de música e colocar o jornalismo, quantas pessoas você vai atingir, ferir? Então, precisa ter cautela com a mudança. Precisa ser bem pensada. Nós estamos pensando já. Na hora certa, vamos querer implantar, com certeza. Ampliar dentro da FM. Mas nosso forte, realmente, é o satélite também, porque, às vezes nós não fazemos jornal para o vale, para cá, mas nós mandamos por satélite para o Brasil inteiro. Então, nós podemos, com todos os estúdios interligados, fazer três, quatro programações simultâneas diferentes, entendeu? Simultâneas, mas para canais diferentes. Cada um fala de um assunto, mas um está no satélite, outro está no Grande Vale, outro está na onda curta e outro está no FM. Então, você faz tudo isso aqui dentro do complexo. Mas o jornalismo é o mais forte que nós temos hoje. São seis jornalistas e um repórter que formam o grupo. 
P: A programação da rádio sempre foi distribuída dessa maneira? E agora, aos 60 anos, vocês estão com idéias novas, estratégias novas?

R: Nós já mudamos. Com a mudança da direção este ano, o padre César assumiu e então já começamos a mexer com a ondas médias e a ondas curtas foi revitalizada, mudada um pouquinho, passando pelos locutores e a produção necessária para "alimentar" os locutores. Então, deixamos dois livres, produção e locução, para que se converse e se coloque em prática aquilo que tem que ser feito, de acordo com as orientações. E “foi feito” vários encontros e abrimos espaço para todos os locutores manifestarem o que gostariam de fazer e o padre César foi bem enfático no sentido de dizer que eles podem fazer o que quiserem, que eles têm liberdade, mas com responsabilidade. Então, eles estão fazendo isso hoje e deu certo. Então, está indo bem, a ondas curtas está indo bem. Tem locutor que passa um pouco, fala muito, tem que segurar. Não é isso que a gente quer. Então, já mudou. A ondas curtas já mudou pensando nessa nova cara. Na AM, a mudança já aconteceu. As implantações, no mês passado saiu um de férias e este mês saiu outro. Então, fica difícil você implantar um negócio e os dois principais locutores de férias. Então, tivemos que pôr "feristas” e não tem como você exigir, você vai só tampar buraco. Então, a gente está agora adaptando a onda média, dando uma nova cara, mais light, uma coisa mais solta, não é aquela rádio presa a um monte de coisa. E a FM também passa por uma mudança, até setembro já está pronto.

P: E como é a programação?

R: Ela vai permanecer jovem, mas sem perder a identidade, esse é o nosso modelo.

P: E aí vocês têm que tipo de programa na FM?

R: Esporte na FM, não temos, só na AM. A gente faz quando é Copa do Mundo, fazemos em cadeia FM e AM, ondas curtas e médias. Agora, na FM é só, no dia a dia, no cotidiano, temos informação de esporte, sim, os principais resultados, previsão do tempo, temperatura, essa questão social, economia de água, campanhas institucionais, como eu falei, numa linguagem de FM, que é diferenciada do AM.

P: A Rede Aparecida tem um protagonismo na Rede Católica de Rádio. É a principal geradora?

R: É a principal. É só ela hoje. Antes era Goiânia que gerava com a gente. Por exemplo, $R C R$ em Debate fazia em Goiânia num sábado e a Rede Aparecida noutro, intercalava. A cada 15 dias, um. Para não pesar muito. Não desgastar. Então, Goiânia já desistiu, não gera mais. Jornalismo também desistiu, agora gera tudo aqui. Aqui, nós temos jornalistas, pagamos jornalistas em Brasília, pagamos mensal, são contratados. E em São Paulo também temos outro contratado. E temos correspondentes, que são voluntários, das emissoras ligadas à própria Rede Católica de Rádio. Mandam todo dia. 
P: E a ideia é ampliar ainda mais, unir os esforços?

R: A gente tem ampliado mais ainda. A gente tem mantido contato com as emissoras, mas há uma dificuldade muito grande para as emissoras mandarem matéria para a gente. Eu não sei qual a dificuldade deles, talvez o medo de mandar matéria, porque a redação própria está muito aquém ainda, dentro do jornalismo, você sabe, é difícil de achar pessoas que sabem redigir. É uma dificuldade geral, a redação. Nossa, eu vejo aqui, falo pro Ederson [Ederson Santos, editor-chefe da Rádio Aparecida], eu não sou jornalista, mas sou um cara quase perfeccionista. São 29 anos de gerência de rádio e administração. Eu apresento o Jornal dos Jornais da tarde [das $17 \mathrm{~h} 30$ às 18h]. Quando eu pego o jornal e olho, eu falo: "Gente, essa redação não está de acordo”. Você sabe quando é jornalista ou quando é “Control C” e “Control V”. Mas, melhor assim do que escrever errado.

P: Antigamente era o gilette press...

R: Exatamente, Mas é melhor você cortar o jornal, marca a data e a fonte está ali (risos). Mas é que o acesso às informações e à internet que todo mundo tem. Você ouve o rádio e lê na internet e é a mesma notícia. Até a palavra é igual. É tão chato isso. Mas, melhor do que escrever errado. Lógico que são todos jornalistas novos, tão chegando no mercado agora, têm uma longa caminhada para frente e isso tudo tem que ser levado em consideração também. Mas a preocupação do noticiário é muito grande com isso tudo. 


\section{APÊNDICE D}

Entrevista com Catarina Jatobá, editora do Jornal Canção Nova $2^{a}$ Edição, realizada no dia 10 de agosto de 2011, em Cachoeira Paulista.

\section{P: Como surgiu a rádio e o grupo de comunicação Canção Nova?}

R: A empresa de comunicação pertence à Fundação João Paulo $2^{\circ}$. Por trás da empresa de comunicação existe uma comunidade católica. Então, a Comunidade Canção Nova foi criada na década de 1970, pelo monsenhor Jonas Abib, e começou como uma comunidade apenas, uma comunidade de vida, onde jovens se reuniam para morar em comunidade e anunciar o Evangelho. Então, tudo começou bem pequeno. Depois, foi adquirido um horário na rádio, se conseguiu uma rádio, que era de curto alcance e as coisas foram crescendo. Deus foi confiando mais. Não foi, assim, digamos, criado, "vamos criar uma empresa de comunicação”. Foi acontecendo. Depois veio a TV, que já há mais de 20 anos nós temos a TV. E agora a internet também. Então, nós trabalhamos hoje com os meios de comunicação. O nosso desafio é anunciar o Evangelho e levar a palavra de Deus através dos meios de comunicação. Hoje nós temos os três: internet, rádio, TV e temos também uma revista, que é para os nossos sócios, e o que surgir mais a gente vai entrar, para anunciar o Evangelho por todos os meios. Então, temos a rádio e, dentro da rádio, o jornalismo. Sobre a história, eu sinceramente, não saberia te informar exatamente quando começou o jornal, porque eu moro aqui há três anos. Vim da Bahia e sou missionária também. Nós temos, aqui, trabalhando conosco missionários e colaboradores, que são nossos funcionários. Então, aqui, você vê, é tudo misturado. Os missionários são voluntários. Nós não recebemos financeiramente. Eu não sei te informar exatamente quando começou. Sei que já tem um bom tempo. Está no terceiro ano que estou aqui. Eu vim pra cá em 2009. No ano passado, eu morei em Queluz e, este ano, voltei para cá, sempre com essa mesma função.

P: Você fez faculdade de jornalismo?

R: Fiz, sou formada. Me formei em Salvador, que é onde eu morava, em 2006, e vim pra cá. Quando eu cheguei, em 2009, já assumi a rádio. Eu coordeno o trabalho da equipe. Mas, aqui no jornalismo nós temos a nossa editora-chefe, que coordena os três núcleos, que é o da TV, da rádio e da web, que é a Liliane Borges. Então, eu fico mais coordenando o trabalho da equipe da rádio, e mais, logicamente, o material, o conteúdo. Zelando por todo o conteúdo que a gente divulga.

O nosso jornal é para a rádio AM, que vai em rede. Nós temos a programação e, nessa hora, todas veiculam o jornal. Nós somos uma rádio de essência religiosa e não temos fins comerciais, nem lucrativos. Tanto que não temos propagandas comerciais. É mantido pelos sócios. 
P: Qual a importância do jornalismo para a rádio? Por que a rádio adotou o jornalismo? Quais são os jornais que vocês produzem?

R: Nós temos dois jornais, o da $6 \mathrm{~h} 30$ e das $13 \mathrm{~h}$. E temos os boletins também, que correspondem àquela percentagem que é exigida por lei, por regulamentação, para a rádio. Nós temos quatro boletins, em torno de cinco minutos. Vão ao ar às 10h05, 14h35, outro às 17h, só que esse está passando por uma reestruturação, e tem o das 20h. E nós temos também um programa que vai ao ar aos domingos, às 6h30, que se chama Notícias da Igreja, que é o resumo das notícias semanais da Igreja. Isso não é nem uma questão de necessidade de notícia, mas é que a gente quis colocar mesmo na nossa programação, para deixar o ouvinte informado das notícias da Igreja. Porque nós queremos ser a voz da Igreja nos meios de comunicação. Se a gente não falar da Igreja, quem vai falar? Muitas vezes, as pessoas sabem o que está acontecendo na Inglaterra, em Londres, mas não sabem o que está acontecendo na própria paróquia, que o pessoal está arrecadando roupas para doar em benefício de alguém e a pessoa não vai ajudar por desconhecer.

P: E o enfoque do jornal é nacional ou regional?

R: Nós temos um enfoque nacional por sermos uma rede. Quando há uma questão mais específica, a gente dá, mas sempre puxando para o nacional. As notícias da Igreja são sobre o Brasil e mundo. O que acontece na Igreja, em geral. O objetivo do nosso jornalismo é deixar o nosso ouvinte informado, porque a gente sabe que tem pessoas que ouvem a Canção Nova o tempo inteiro. Então, a gente não quer que a pessoa fique bitolada, porque hoje a gente sabe que uma das nossas maiores necessidades é a comunicação. A gente precisa estar informado, saber o que se passa no mundo, não ser um cristão alienado, porque essa não é a nossa proposta: de que as pessoas fiquem ali rezando o tempo inteiro, sem saber da necessidade de quem está do lado. Então, é informar, conscientizar, sempre primando também pelo nosso perfil editorial, que é "um jornalismo a serviço da vida e da esperança”.

P: Como vocês selecionam as notícias? O que entra e o que não entra? Qual o enfoque é dado?

R: A nossa seleção de pauta é: assim que a gente chega, a gente dá uma "zapeada" pelo mundo. A equipe é formada por quatro pessoas na rádio, dois funcionários e dois missionários e tem em outras casas de missão também. Casas de Missão são as nossas filiais, porque a gente tem aqui a central, em Cachoeira Paulista, e as nossas sucursais, que mandam material. Por exemplo: no Rio de Janeiro está acontecendo alguma coisa. O pessoal produz e manda o áudio para a gente. Curitiba, nós temos uma repórter lá também, que manda sempre manda matéria, a Fabiana Sá. Brasília tem a Gisele Pires. No Rio, tem o Áureo Ameno. Em Pernambuco, tem o Josenildo Pedro. São correspondentes. Nós temos também, fora, em Roma, quando precisa o pessoal sempre dá uma ajuda. A Canção Nova está lá também. Os correspondentes de fora são mais esporádicos. Os de dentro, são mais fixos. Por exemplo, 
agora a gente tá cobrindo a Jornada Mundial da Juventude, que vai acontecer em Madri, com o papa, agora, neste mês. Então nós temos lá o nosso correspondente, a Cris [Viana, diretora geral da Rádio Canção Nova] vai e tem mais uma outra pessoa de Roma que foi pra lá ajudar também. Então, eles mandam material pra gente. Então, temos as casas de missão onde a Canção Nova atua, que mandam material para nós. Onde tem rádio, a gente consegue uma ajuda das pessoas que trabalham na equipe da rádio lá, para enviar as matérias para a gente, mas não é aquela coisa fixa, todos os dias, porque depende da demanda também, depende do assunto.

\section{P: Como é produzida a primeira edição?}

R: Nós produzimos matérias “frias” no dia anterior. As factuais, a Flávia Pereira, que é produtora e apresentadora também, chega bem cedo, 5h, e aí ela vai procurar o que tem de novo. E como, de manhã cedo, a equipe é mais reduzida, a gente já deixa o que pode ser aproveitado do dia anterior, que é mais "frio", e quando ela chega aqui, ela acrescenta as novas, e também a gente pega matérias de agências, como a agência Rádio Web, até por uma questão de tempo. Então, o jornal da manhã, tem mais notícias de agência. À tarde, como dá mais tempo de produzir, então é uma coisa mais nossa. Temos um tempo de produção maior e equipe maior. À tarde, é raro ter. Só no jornal da manhã por uma questão de necessidade e só matérias boas, aquelas que a gente julga que dá para entrar, que tem um tempo de produção maior.

P: O jornal da tarde pode ser considerado mais completo?

R: Sim porque tem a Flávia, eu, a Rose [Roselaine Iria] e tem as outras pessoas também que ajudam.

P: Com quais agências vocês trabalham?

R: Além da Rádio Web, tem a Agência Rádio 2 de Notícias.

P: E vocês trabalham com as agências de notícias tradicionais, como Reuters, Agência Estado?

R: Não. Só com as agências de notícias de rádio. Então, a gente dá uma "zapeada” nos principais sites de notícia, vê o que está acontecendo e seleciona, primeiro, pelos critérios jornalísticos mesmo, o que se denomina como notícia, a gente vai pela importância, pelo número de pessoas que abrangeu, pelo interesse público, então, tudo isso é usado como filtro na seleção das pautas, o que vale e aquilo que não vale. Nós damos prioridade também para o que é Igreja, o que é notícia da Igreja, o que o papa está falando, o que os bispos do Brasil estão falando, se surgiu alguma situação polêmica no Brasil em que a Igreja tenha sido colocada em discussão, o que a Igreja fala sobre isso, a gente dá essa prioridade. E também os assuntos de interesse geral. Nós temos todas as editorias, a gente não prioriza uma coisa só e exclui outra, não. A gente dá a notícia da Igreja, sim, mas também as notícias em geral. 
P: Vocês abrem com notícias da Igreja?

R: Em geral, sim. Mas, lógico, se tem alguma notícia bombástica, muito mais importante, e a notícia da Igreja é mais secundária, a gente vai dar, sim. O que a gente não dá: notícias sensacionalistas, assuntos fúteis, aquilo que a gente vê que não vai contribuir para o nível cultural do nosso ouvinte, porque a gente prima pelo nível do nosso jornal. A nossa seleção de pauta, então é assim, a gente procura o que está “bombando" pelo mundo hoje, mas também aquilo que é relevante para nós. Então, por exemplo, quando teve o casamento do príncipe William e da Kate, a gente falou? Falou, porque o mundo inteiro tava falando e é a monarquia, a realeza, mas o nosso diferencial é que a gente não deu aquele sensacionalismo, passando o dia inteiro falando sobre isso; é desnecessário gastar tanto tempo nesse assunto. Então, o nosso diferencial é esse, não é que a gente deixou de falar, ou omitiu, mas tudo na medida certa, tudo com dosagem.

P: Por exemplo, um caso como o de Realengo, no Rio, que foi de uma violência extrema, não tem como não dar, né?

R: Não tem como não dar, e nós falamos, sim. A gente procura não deixar de dar. É violência? Sim, mas a gente precisou falar, aquilo que precisou ser comentado, o posicionamento da Igreja. Não me lembro se foi dom Orani [João Tempesta], o arcebispo do Rio, que comentou, mas quando tem o posicionamento oficial da Igreja, a gente coloca, divulga o que a Igreja está falando sobre isso, como os cristãos podem reagir diante disso. Não pra ficar só: “Ah, morreram tantas crianças e pronto”, mas suscitar essa consciência, o que a sociedade pode fazer, como nós, como um veículo católico de comunicação, podemos contribuir para que a sociedade veja isso que está acontecendo e o que cada um pode fazer, como uma prestação de serviço.

P: Quais editorias vocês têm?

R: Política, Economia, Igreja, Saúde, Meios de Transporte, quando tem, Aviação, Tecnologia. Tudo isso para a gente formar o cidadão por completo, para deixar o nosso ouvinte informado de todas as coisas, de todas as áreas. A gente procura sempre dar mais essa visão aberta, de que as pessoas precisam se informar: "A taxa básica de juros da Selic subiu para 12,75\%”. A gente procura explicar um pouco o que isso interfere na vida da pessoa. Um enfoque de Economia seria assim. Então, “o índice de preços ao consumidor está em tantos por cento...” O que isso vai afetar no seu bolso no fim do mês? Como vão ficar as suas contas, a cesta básica, então dar essa visão, digamos assim, mais clara. Agora a crise financeira que está acontecendo nos Estados Unidos. A gente procura explicar para que a pessoa fique por dentro de tudo, de todos os assuntos.

P: Está tão longe, aparentemente, mas é importante.

R: Exatamente. O que isso pode influenciar. 
P: O público de vocês é muito amplo, em todo o Brasil, e até em outros países, agora os Estados Unidos...

R: Sim. Nossa rádio, por ser web, então chega no mundo inteiro. Mas, o nosso enfoque é o Brasil. A gente procurar fazer assuntos que são de interesse nacional, mas, lógico, a gente não pode falar sempre do Brasil inteiro. Então, o que a gente faz? Vamos supor: está tendo uma campanha de vacinação contra poliomielite. Então, a Fabiana Sá, lá no Paraná vai falar: “Aqui no Paraná, a campanha começou, está sendo assim, está sendo assado... no Brasil inteiro já começou. Você pode se dirigir aos postos, levar sua criança”. É dada, se necessário, aquela visão local, mas sempre puxando também para o nacional, para não ficar aquela coisa somente localizada.

P: Vocês têm bastante interatividade com os ouvintes?

R: A gente não tem tanto essa interação, esse retorno do nosso ouvinte. Agora que a gente tá começando mais e procurando chegar próximo das pessoas através das nossas redes sociais. Através do Twitter que a gente tá começando essa interação, então agora a gente faz essa divulgação todos os dias do jornal, que vai ao ar à uma hora. Então tem essa pessoa que é responsável por divulgar para fazer essa interação das redes. A gente divulga o jornal, as principais manchetes: "Hoje vai ter isso, o Jornal Canção Nova $2^{a}$ Edição vai ter isso, então acompanhe”. É uma forma de a gente estar começando a chegar, de buscar o ouvinte e entender quem é nosso ouvinte o que ele quer ouvir.

P: E quais são os outros canais de interatividade? Como o ouvinte se comunica com vocês?

R: Sim, o que eu falei dessa nossa dificuldade de comunicação com ouvinte é específico do jornal da rádio, porque, apesar de ser ao vivo, não é um programa interativo, como tem o Clube do Ouvinte, o Deus Proverá, tem outros que a pessoa manda, o Geração PHN, que é às 14 horas, então, a pessoa manda lá o e-mail, fala no Twitter: "Estou gostando disso, queria ouvir aquilo”. Já, no jornal, não. Então o jornal seria, digamos um retorno mais a longo prazo. Talvez seja isso que dificulta. Por isso que eu falei que agora é que a gente tá começando a buscar esse outro meio, que é o Twitter, que é uma rede social que está crescendo de uma forma tão rápida, pra que a gente possa ter esse retorno do ouvinte. Mas, nos outros programas o retorno é muito intenso, imediato, então as pessoas comentam, falam, interagem.

P: E, de alguma maneira, isso pode interferir nas pautas, na abordagem? Essa interatividade pode dar um retorno para vocês, no sentido do ouvinte sugerir pautas, por exemplo?

R: Sim, nós somos muito abertos a isso. Eu falo pela cultura do nosso jornalismo aqui da Canção Nova, como já acontece no jornal da TV, as pessoas comentam, no Twitter, do que gostaram, dão sugestões de pauta, nós somos muito abertos a isso. Então, nós temos essa perspectiva de diálogo com o ouvinte, mas teria que ser intensificado no caso da rádio, do jornalismo da rádio. 
P: Normalmente vocês têm uma equipe de reportagem, que vai até os locais fazer as coberturas?

R: Sim, como acontece: quando tem uma coletiva de imprensa ou algum evento, aí a gente costuma enviar uma pessoa da nossa equipe. No caso, da rádio, eu é que vou mais. Por exemplo, teve uma coletiva em Aparecida, os bispos falando sobre aquela tragédia no Rio, das chuvas. Então, eu fui fazer a coletiva, a cobertura, mas, como a nossa equipe é reduzida, a gente não tem como estar sempre na rua, então, o nosso contato é feito também por telefone, mas como nós trabalhamos em conjunto com as outras mídias, com a web e com a TV, no caso, o repórter da TV, que vai fazer uma entrevista, chega e traz uma notícia muito boa. Então, eu tenho acesso a essa entrevista. A gente trabalha com essa interação. Da mesma forma que, às vezes, eu faço uma entrevista por telefone, para o nosso jornal, e o pessoal da web também utiliza. Então, a gente trabalha em conjunto, estamos sempre trocando figurinhas. Então, se eles vão e fazem uma matéria muito boa, a gente aproveita as entrevistas, lógico, adaptando a linguagem para rádio e aí a gente monta as matérias. Você vai ver que temos muitas matérias frias, pautas interessantes sobre saúde... a gente faz reunião de pauta uma vez por semana, na quinta-feira, com toda a equipe, para planejar tudo aquilo que vamos fazer durante a semana e já projetar o mês. Então, a gente já pensa aquilo que vai ter, divide as pautas, o que cada um vai correr atrás. Por exemplo, agora a gente tá montando um especial sobre vocações, porque esse mês de agosto é o mês das vocações. Então, vai sair na última semana, cada um tem uma matéria, a gente tá produzindo e é uma produção jornalística como outra qualquer, no caso acompanhando o calendário católico. Quando foi a Semana da Mulher, a gente fez um especial sobre mulher... então a gente tá procurando isso pra enriquecer o nosso jornal. É uma coisa, são reportagens aprofundadas e que têm sido bastante úteis e que vão entrando ao longo dos dias.

P: Vocês têm essa postura de evangelizar pelos meios de comunicação e também pelo jornalismo. Na sua opinião, é possível misturar as duas coisas?

R: É possível. É um desafio muito grande, porque aparentemente, como você vai evangelizar pela notícia? Como você vai falar o que aconteceu e ali evangelizar? Mas, evangelizar é justamente você permear a notícia pelo Evangelho. Você coloca a essência do Evangelho naquilo que você fala, naquilo que você transmite. Daí vem o nosso perfil, a nossa maneira de fazer, com respeito pelo outro, a gente evita falar de escândalo, de violência. Quando é uma coisa que é realmente necessária a gente vai apurar os fatos, para primar pela pessoa, pela dignidade da pessoa. Evangelizar no sentido também de apresentar ao nosso público, ao nosso ouvinte, aquilo que ele pode fazer de bom também. Por exemplo, no início do inverno, a gente fez a campanha do agasalho, fizemos uma matéria sobre doação de agasalhos, doação de sangue, coisas de interesse público para despertar nas pessoas a sensibilidade e a necessidade do próximo, Então, é dessa forma que eu vejo que a gente pode evangelizar através do nosso jornalismo, com esse nosso diferencial, que é “a serviço da vida e da esperança”.

P: Vocês seguem as orientações da Igreja em relação à comunicação? 
R: Sim, nós estamos sempre abertos à Igreja, porque nós somos a Igreja. A Canção Nova está a serviço da Igreja. Falam que a Canção Nova é isolada e tal, mas não é nada disso. Nós somos submissos à CNBB. Tudo aquilo que a CNBB nos passa, em termos de documento, a gente busca obedecer. Tudo aquilo que os bispos falam e nos exortam é o que a gente procura seguir, que é a nossa linha mesmo, de ter esse respeito, de dar essa notícia de uma forma diferenciada.

P: Vocês têm uma redação em São Paulo?

R: Lá tem também uma equipe e, quando precisamos de cobrir algum evento, então essa equipe nos ajuda. E, em outros locais, por exemplo, teve o encontro de comunicação dos bispos no Rio de Janeiro, tem uma casa lá e tem uma equipe. Então, eles nos enviaram notícias. A equipe da TV tem as sucursais, que são fixas. Da rádio não é tão fixa, mas a TV tem. Tem uma equipe aqui no vale e também nas sucursais. A equipe faz reportagens para a TV e gente aproveita o material bruto.

P: Na sua opinião, o que é possível fazer para melhorar ainda mais o jornalismo na rádio?

R: Sempre temos coisas a melhorar. Hoje, a Canção Nova já deu muitos passos no jornalismo. Então, aquilo que a gente procura aprofundar e crescer é justamente nas nossas produções próprias. Por exemplo, no jornal da manhã, a gente ainda tem alguma necessidade de produzir material, pegando material das agências, mas o nosso sonho seria de que tudo fosse produzido por nós, mas ainda não temos condição, até mesmo pela equipe. Nossa equipe ainda é um pouco reduzida, mas é a cultura da própria Canção Nova. Aqui, a gente diz assim que ninguém é bom sozinho. Então, da mesma forma, aqui, no jornalismo, ninguém é bom sozinho. A web, a rádio e a TV, todo mundo trabalha em conjunto. As nossas casas de missão, é tudo em função de uma missão, que é evangelizar. Então eu falo que a nossa equipe é "x”, mas na verdade a gente conta com outras pessoas, que, de boa vontade, se disponibilizam a ajudar. Por nós não termos esse perfil financeiro, caráter comercial, a gente tem essa postura aqui dentro da fundação, de ajuda, de cooperação, que foge daquela competição, cada um querendo ser melhor que o outro, se sobressair. A gente procura cada um ajudar o outro para que se sobressaia a nossa missão, que é evangelizar. 


\section{APÊNDICE E}

Entrevista com Reinaldo César, jornalista, radialista e apresentador do Jornal Canção Nova $2^{a}$ Edição, realizada no dia 10 de agosto de 2011, em Cachoeira Paulista (SP).

\section{P: Como começou o jornalismo na Canção Nova?}

R: Começamos com boletins de cinco minutos, de hora em hora, das 8h da manhã até às 10h30 da noite, em 2001. Em 2003, a gente já começou a ter um pouquinho mais de tempo para o radiojornal, um minijornal de 15 minutos, na hora do almoço, entre meio-dia e 1 hora da tarde. Até que se extinguiram os boletins de hora em hora, os boletins ficaram mais espaçados e se criou o jornal de meia hora, nesse horário, das 13h à $13 \mathrm{~h} 30$ [atualmente, o jornal é apresentado das $12 \mathrm{~h} 30$ às $13 \mathrm{~h}]$. A evolução que houve, na verdade, foi uma melhoria no conteúdo, na qualidade, porque a gente era muito mais dependente de agências. A gente ainda é dependente, mas éramos muito mais. Então, hoje a gente conta com uma participação maior da equipe própria da casa, de algumas casas. Hoje a gente conta com a participação da Fabiana Sá, que é de Curitiba, e a gente conta com a participação de São Paulo também, que a gente não tinha, e às vezes do Rio. Por causa da correria, às vezes da própria televisão, então não dá tempo. Mas, quando tem coisas importantes, a gente pega o próprio repórter, às vezes na rua, pelo celular, e ele entra ao vivo, seja do Rio, São Paulo, Brasília, de onde for, até de Roma, de Portugal, Fátima, e até mesmo de Israel. A gente tem casa de missão lá. Em Jerusalém, em Belém. Então, quando tem notícia muito importante, a gente põe aqui no telefone e o pessoal entra ao vivo. Se a gente chama no jornal ao vivo, às vezes a linha cai e a gente pode ficar na mão. Então, a gente consegue gravar antes, no horário muito próximo do jornal. A gente grava porque é preferível. É preferível gravar para não perder o jornal. Depois, mais tarde, a notícia volta com outras informações, com comentário, não fica sem dar continuidade. Aquilo que a gente chama de suíte; a gente vai "suitar" depois, seja hoje, amanhã e por aí vai.

P: Qual é a sua trajetória no jornalismo?

R: Eu trabalho nos meios de comunicação há 28 anos. Eu comecei no rádio, em Cruzeiro, e ali eu tive oportunidades, fui desenvolvendo e a gente fazia reportagens, que é importante. Acho que o interior está falhando muito porque as mídias locais são muito dependentes das prefeituras e câmaras municipais, infelizmente. Então fica uma coisa meio atrelada, amarrada. E o jornalismo quase não existe. Passa a ser um jornalismo de “chapa branca”. E eu odeio isso. Acho que as rádios do interior, a maioria dos meios de comunicação das cidades do interior está comprada e vendida. Acho que as rádios precisam ter mais responsabilidade. Não depender de prefeituras, de câmaras e, se a prefeitura ou câmara quiser fazer propaganda no jornal, deixar bem claro o que vai ser dito, como vai ser dito, a verdade vai ser falada e vai ser levada ao público. Eu acho que quem pede isso é a sociedade e as sociedades locais. Aí entra uma política de comunicação local ou de cidadania até mesmo, para que as pessoas também 
ajudem no policiamento, exigindo das mídias mais transparência e não notícias maquiadas, mascaradas, como ocorre.

E, na minha época, quando entrei, a gente tinha total liberdade, a gente estava na rua, fazendo jornalismo de verdade. E já como radialista. Depois a gente foi percebendo algumas mudanças, prefeitos que foram assumindo e as coisas foram mudando. Começaram a comprar uma rádio ali, um jornal aqui. Não podia falar determinadas coisas e eu achei horrível, eu nunca compactuei com isso. Sempre fui perseguido por isso e talvez por isso não esteja nessas mídias seculares, porque a gente percebe que a parte ideológica e tudo o mais, ela é muito grande. Eu não vou dizer que os próprios proprietários de emissoras de rádio e TV não tenham também essa idéia, mas o pior mesmo é quando você vê isso acontecendo às claras e ninguém faz absolutamente nada. Nem a sociedade e nem os jornalistas e radialistas, que, às vezes, com perdão, os colegas podem ficar aborrecidos, eu peço o perdão da palavra, se vendem, viram reféns alguns deles. E eu, para não ficar refém, eu combatia. E, combatendo, você é perseguido.

Então comecei assim e, depois, foi havendo uma mudança muito grande. E, com eu tenho uma identidade muito grande com a Igreja, tive a oportunidade de trabalhar aqui. Mas antes eu passei pela Inconfidência, por empresas afiliadas da Globo, da Jovem Pan, da Metropolitana, Difusora, fiz free lancer inclusive em Goiás, Minhas Gerais e em São Paulo. Viajei muito, me transformei num locutor esportivo, me dediquei muito, cheguei a um nível muito bom, modéstia à parte, de locução esportiva, no estilo do Osmar Santos, mas infelizmente os caminhos foram sendo desenhados e fui buscar outras possibilidades, porque também eu não estava vendo muito futuro nessa área. Fui também estudar mais até chegar na Canção Nova, em abril de 2001.

\section{P: E como foi a sua trajetória na Canção Nova?}

R: A partir daí, a minha vida mudou bastante porque eu fui sendo transformado pelo crescimento como pai, como marido, como ser humano, mas sem nunca deixar de lado o jornalismo. O jornalismo tem que ser feito voltado para os interesses da sociedade, o interesse do bem comum, das pessoas, fazer a diferença, levar esperança, não ficar reclamando da vida, mas apontar caminhos, não no sentido de um jornalismo denuncista, mas que mostra caminhos que levem as pessoas a um grau de esperança, porque, sem esperança ninguém vai a lugar nenhum.

P: Como é sua rotina de trabalho na Canção Nova?

R: Eu começo a trabalhar por volta das 10h, quando chego na rádio, para auxiliar as pessoas no jornal, a gente trabalha em parceria, em equipe; tem duas pessoas produzindo, eu chego para auxiliar e revisar os textos, principalmente. Aí, participo da apresentação do Jornal Canção Nova $2^{a}$ Edição. Logo depois, eu fico já à disposição da televisão [Reinaldo César apresenta de segunda a sexta, das 19h às 19h30, o Canção Nova Notícias, na TV Canção Nova]. Vou almoçar, volto e logo participo das distribuições das pautas, ou seja, do que vai 
ser notícia naquele dia. Evidentemente que, muitas vezes, a gente tem queda de pauta e aí muda o assunto em determinada casa de missão. Por exemplo, em Brasília, a pauta vai ser sobre o TSE [Tribunal Superior Eleitoral]. De repente, cai a pauta e entra um outro assunto, como, por exemplo, uma entrevista coletiva da CNBB. Então, a gente faz a distribuição das pautas e depois já ordena a sequência das notícias, das reportagens, das matérias. E, posteriormente, claro, nós vamos trabalhando os textos e revisando os textos das casas, trabalhando as cabeças, que são as chamadas das matérias do jornal [de TV], revisando GCs [gerador de caracteres], a forma que vai para o ar o GC, que é o nome da pessoa, a função dela, no rodapé, e sempre trabalhando em equipe, conversando, enquanto outros colegas vão fazendo, eu diria, a edição. Então, é uma produção de equipe. Tem o pessoal que coordena as casas e também a recepção das matérias também, que vêm de São Paulo, do Rio, de Brasília, de Aracaju, enfim, das nossas casas.

P: Na sua opinião, o que significa e como podemos definir esse slogan da Canção Nova: "Jornalismo ético, a favor da vida e da esperança”?

R: Estar a serviço da vida e da esperança é olhar para as pessoas, é olhar para a comunidade. Eu vejo que o slogan "a serviço da vida e da esperança”, ele cai muito bem na Canção Nova e também ele é uma referência da CNBB, a Conferência Nacional dos Bispos do Brasil, porque, quando se faz um jornalismo ético, pautado na qualidade, na preocupação com as pessoas, com o ser humano, com seus valores fundamentais, ou seja,quando nós carregamos esses valores que nós temos e mantemos esses valores, nós estamos pautando pela vida e esperança. A essência do jornalismo também não foge disso. Um jornalismo ético vai trabalhar em favor da sociedade, da comunidade. Ele vai informar, levar informação, denunciar, se preciso for, e ajudar nas mudanças, nas transformações que a sociedade vai criando no seu dia a dia. Os meios de comunicação hoje têm uma função social muito importante. Pena que muitos deles banalizaram muito as coisas importantes na vida das pessoas. Eu acho que a Canção Nova está no caminho correto, está no caminho certo. Evidentemente, que nós precisamos avançar, melhorar, qualificar mais também os profissionais que vêm vindo, para que se encaixem dentro dessa proposta, ou seja, que é levar vida, que é levar esperança, que é anunciar à sociedade a boa nova, e qual é a boa nova? Levar vida e esperança para as pessoas à luz do Evangelho.

\section{$\mathrm{P}$ : De que forma fazer isso por meio do jornalismo?}

R: Eu vejo que é necessário cada vez mais qualificar as pessoas. Formação: essa é a palavrachave. Formação das pessoas, sendo ou não jornalistas, para levar alegria, para levar esperança, para levar vida, para edificar as pessoas. A sociedade hoje é ansiosa. Eu não sei se ela está tão bem informada assim, com os meios de comunicação de que dispomos atualmente, com o advento da internet. Então, eu vejo que é preciso avançar na formação das pessoas. Cuidar dos valores fundamentais, que estão sendo deturpados, revertidos, por muitos meios de comunicação. E a gente precisa ter esse cuidado, esse olhar diferenciado, para não fugir daquilo que nós propomos, que é trabalhar a serviço da vida e da esperança, fazendo um 
jornalismo ético, pautado na ética, pautado na decência, sem sensacionalismo barato e fazer um jornalismo de fato voltado para a sociedade, informando, formando, levando alegria e levando a boa nova. E lutando também por justiça, porque o jornalismo da Canção Nova, quando fala de vida e esperança, ele quer ver também esse caminho de paz, esse caminho de justiça. Como dizia João Paulo $2^{\circ}$, sem justiça não há paz. Então, se não há justiça, a paz fica comprometida. E nós precisamos muito trabalhar pela paz a partir de nossas atitudes, nossas ações e o nosso ser. O nosso comportamento também evangeliza. 


\begin{abstract}
APÊNDICE F
Entrevista realizada no dia 2 de novembro de 2012, em São Paulo, com a irmã Vera Ivanise Bombonatto, autora de Evangelizar é Comunicar (2010) e Teologia e Comunicação: Corpo, Palavra e Interfaces Cibernéticas (2011), ambos os livros lançados pela Editora Paulinas.
\end{abstract}

P: Qual o conceito de evangelização para a Igreja Católica, porque vemos que é um conceito dinâmico, que já foi abordado em diversos documentos da Igreja ao longo da História e como podemos entender a evangelização hoje, em face dos meios de comunicação?

R: O núcleo da evangelização continua sempre válido, que é anunciar a boa nova de Jesus Cristo. Diversos documentos da Igreja, como o Evangelii Nuntiandi, vão mostar isso: Jesus morreu e ressuscitou, está no meio de nós e nos ensina que é o primogênito, entre tantos irmãos, como diz a Carta aos Hebreus. Mas o importante, tudo que a gente possa dizer de evengelização, com os meios, com as técnicas, tudo, fica sempre um núcleo e o núcleo é esse: anunciar a Boa nova de Jesus Cristo.

P: E essa mensagem tem a ver com comunhão, com estar solidário com a humanidade, promover e defender a vida? Tem também essas dimensões?

Quando você pega esse conceito de que evangelizar é anunciar a boa nova de Jesus, então você vai perguntar: "Mas, qual é a boa nova de Jesus Cristo? A boa nova de Jesus Cristo é justamente a defesa da vida e, quando Jesus quis sintetizar o seu programa de vida, ele disse: "Eu vim para que todos tenham vida eterna”. Jesus não suportava que a vida humana fosse maltratada, pela doença, pela fome, pela violência, pela morte. Ele não deixava. Ele sempre intervinha por entender que a vida estava sendo machucada. E ele disse concretamente: " $\mathrm{Eu}$ vim para que todos tenham vida e tenham em abundância”. Esse foi o programa de Jesus. Então, anunciar a boa nova de Jesus é anunciar esse valor supremo da vida, da vida humana. E, quando a gente pensa que é anunciar o valor da vida humana, então aí abre um leque muito grande, desde a promoção humana, porque Jesus, quando pregava o Evangelho, quando esteve nesta terra, ele não fazia distinção entre espiritual, material. Ele olhava para a pessoa, a necessidade da pessoa. Se a pessoa tinha fome, ele dava de comer, se a pessoa tinha falta do sentido da vida, ele fazia a pessoa encontrar o sentido da vida. Então, Jesus não fazia essa distinção que depois nós fomos fazendo, e até brigamos tanto: “A Igreja cuida do espiritual, a sociedade, o governo cuida do material”. Para Jesus, tinha uma causa só: a vida. Se a vida estava ameaçada, ele socorria.

P: Existe também uma dimensão de defesa dos oprimidos, conforme defenderam algumas conferências episcopais latino-americanas e a Teologia da Libertação? 
R: Porque Jesus mesmo disse: "Eu sou a vida. Eu sou o caminho, a verdade e a vida”. Então, quando você fala em vida humana, abre um leque incrível. São inúmeros compromissos, inúmeros desafios, incluindo o que ultimamente, sobretudo, o Leonardo Boff tem falado muito, sobre a vida no planeta Terra. "Nós temos um pobre e, se não cuidarmos dele pobre, vamos morrer com ele”. E esse pobre é o planeta Terra. Recentemente, ele lembrou em um congresso que não é o planeta terra que precisa de nós. Nós é que precisamos dele, porque o planeta é nosso habitat.

P: E quais os maiores desafios da evangelização hoje?

R: Hoje se fala em “nova evangelização”. O Evangelii Nuntiandi já fala alguma coisa sobre isso, mas muito pouco. Agora, esse documento do Sínodo dos Bispos fala em "nova evangelização". Esse termo tem um histórico, mas quando o papa João Paulo $2^{\circ}$ usou esse termo, ele queria dizer que nós precisávamos buscar novos métodos, novos modos e novo ardor para evangelizar. E agora, então, a Igreja está tomando esse conceito de "nova evangelização”. Quer dizer, a evangelização não é uma coisa superada, ela é alguma coisa nova. Mas no que ela é nova? Ela é nova no sentido do uso desses meios modernos, na abrangência também de novas questões, como a questão ecológica, que antes não existiam. Então, isso faz com que haja na Igreja, na sociedade, a necessidade de uma nova evangelização, para incorporar esses aspectos que não estavam presentes no processo porque não existiam certos problemas. Então, esses novos problemas, tipo problema ecológico, as novas linguagens, os novos meios é que nos fazem falar numa nova evangelização, frente à nova realidade que está se formando.

P: A ideia é que a evangelização acompanha a evolução e os problemas da humanidade?

R: Sim. A partir do Concílio Vaticano II, o Gaudium et Spes, que fala que todas as alegrias, as tristezas e as dores da humanidade são as alegrias, as dores e as tristezas da Igreja e dos seguidores de Jesus. Então, conforme o caminhar dos tempos, a Igreja tem que ir acertando o passo, caminhando com os tempos, não pode ficar atrasada.

P: Existem na Igreja diferentes abordagens sobre o que é evangelização, por exemplo, em relação à Santa Sé, à América Latina e à CNBB [Conferência Nacional dos Bispos do Brasil]?

R: Eu não diria que existem diferentes abordagens, eu diria que existem enfoques diferentes frente a diferentes realidades. Então, por exemplo, para a realidade da América Latina nós precisamos de alguns enfoques especiais, como o enfoque da injustiça social, o enfoque da desigualdade. Já a Europa tem outros enfoques, como o enfoque da falta de sentido para a vida, o secularismo. O Oriente tem outro enfoque, que é o enfoque do diálogo inter-religioso. Então eu acho que a matriz é a mesma, mas os enfoques mudam de acordo com o contexto histórico. Porque tem que encarnar, como Jesus se encarnou, também nós temos que encarnar a sua mensagem. São coisas diferentes encarnar a mensagem de Jesus na América Latina e encarnar a mensagem de Jesus na Europa, no Oriente, na China, na Índia. Então, o contexto é 
que vai exigir determinados enfoques diferentes, mas a mensagem tem o seu núcleo central, que é o mesmo.

P: E com relação às diferentes correntes dentro da Igreja? Cada uma veria a evangelização de uma maneira?

R: O ponto básico é que nós vivemos em um mundo plural. Então, nós não podemos mais pensar que todas as entidades pensam da mesma forma. Umas dão mais enfoque ao espiritual, outras dão mais enfoque ao anúncio, outra dá mais enfoque à prática de Jesus. Então, nós vivemos em um mundo plural, com diferentes interpretações da mensagem de Jesus. O padre João Batista Libânio fala muito nos “cenários de Igreja”. Cada cenário de Igreja tem uma nuance em relação à evangelização. Ele tem um livro justamente abordando essa questão, que se chama Cenários de Igreja. Ele mostra como cada cenário de Igreja tem um determinado enfoque, como esses cenários comportam diferentes interpretações da evangelização.

P: Especificamente em relação às rádios católicas que fazem jornalismo, como seria um jornalismo evangelizador? Haveria uma maneira cristã de fazer jornalismo?

R: Uma maneira cristã de fazer jornalismo seria colocar em prática os ensinamentos de Jesus. Por exemplo, a partir de qual perspectiva você se coloca para dar uma notícia? Você pode dar uma notícia a partir da perspectiva de acusar, de denunciar as autoridades porque não cuidaram de determinadas coisas. Você pode dar uma notícia a partir da perspectiva do desrespeito à vida humana. Então, a perspectiva cristã, a perspectiva do ensinamento de Jesus, porque esse é o diferencial, o modo é a partir da defesa da dignidade humana. Então, você dá a notícia mostrando o quanto aquela notícia foi contra a dignidade da pessoa, se se respeitou a pessoa, se se respeitou a vida, essa é a perspectiva cristã, o respeito à vida, ao valor da vida, fazer uma leitura esclarecedora, conscientizadora sobre esses valores e não o mero espetáculo, o jornalismo barato, o sensacionalismo e a apelação.

P: E qual seria a pauta de um jornal evangelizador? Que temas seriam ou não abordados, em face daquelas questões contra as quais a Igreja se posiciona, como aborto e outros temas?

R: São Paulo tem uma frase em uma de suas cartas, que diz: "Nada é tabu para o cristão, mas nós devemos falar cristãmente de todas as coisas”. Nada é tabu, porque é humano e nada que é humano é desprezível. Afinal, Jesus encarnou e tornou-se humano. A diferença é o modo como falamos. E também quando eu falo da violência. De que forma Jesus falou sobre a violência? Ele denunciou a violência. E nada deve ser tabu para o cristão, mas tudo tem que ser abordado a partir da ótica cristã, de promoção de valores da vida.

P: Nós poderíamos entender que o jornalismo evangelizador objetiva converter as pessoas para uma determinada causa?

R: Não, eu diria que ele objetiva se colocar ao lado da pessoa humana e dos necessitados, na perspectiva do Gaudium et Spes. 


\section{APÊNDICE G}

Entrevista com o frei João Carlos Romanini, presidente de Rede Católica de Rádio (RCR), realizada no dia 22 de fevereiro de 2013, em São Paulo.

\section{P: Qual a sua formação?}

R: Além de ter feito Filosofia e Teologia, eu passei pela área de Administração. Tenho formação jornalística e sou pós-graduado em Comunicação e Multimídia, pela Universidade de Caxias do Sul, Fernando Pessoa e Toulon. O Jornalismo eu fiz depois de todas as outras, porque os capuchinhos disseram: "Você tem que administrar uma rádio”. Então, como eu só tinha Filosofia e Teologia, tinha que me qualificar tecnicamente. Aprendi Administração e depois eu saltei para o Jornalismo.

P: E a Rede Católica de Rádio, como ela surgiu?

R: A Rede Católica surgiu, a princípio, da necessidade das rádios se organizarem. Então, foi ali no início dos anos 90, com o advento dos satélites e das grandes redes. Foi uma coisa, mesmo, do tempo tecnológico, eu diria. Surgiram as redes nacionais, e atrás da rede nacional tinha uma questão política de sobrevivência, o Brasil precisava se nacionalizar, tínhamos que tomar conta do espaço geográfico brasileiro. O governo politicamente tinha isso e ele estava apostando também em mídia em rede. Consequentemente, as rádios se mexeram para buscar a mídia e se organizaram em rede. Então, no início dos anos 90, se formatou a Rede Católica de Rádio. Ela tem hoje 17 anos e, a princípio, ela nasceu do diálogo das grandes redes - tinha a Rede Aparecida, a Difusora, de Goiânia, Rádio Imaculada Conceição, da Grande São Paulo, a Canção Nova, de Cachoeira Paulista, que surgiu já num formato mais arrojado, numa comunicação dedicada à Igreja, mais a Paulus, dos paulinos, que, na época, tinham a Rádio América, aqui em São Paulo também... era uma questão de organização interna, de produtores de conteúdos católicos. Daí, se formou essa grande rede. Tinha também, no Paraná, a B2B, que eram os maristas, que estavam lá, vinculados com a PUC do Paraná, que depois, na configuração, saíram. Os paulinos saíram também. Então, ficaram cinco grandes redes: a Aparecida, a Canção Nova, Milícia da Imaculada, Difusora, de Goiânia, e Rede Sul. Essa é a configuração da Rede Católica hoje. Ao longo desses 17 anos, com as mudanças de configurações externas políticas, sociais e comunicacionais, começaram a surgir outras pequenas redes de emissoras católicas. Então, agora, a Rede Católica começa a pensar numa reconfiguração dela, porque tem toda essa questão estatutária. Essa grande rede começou a criar novas redes, mais segmentadas. Este ano, a gente está começando as tratativas para começar a dialogar com elas, para que elas possam se incorporar a esse grande projeto de comunicação católica no Brasil, porque a comunicação católica tem muitas facetas. 


\section{P: E quantas emissoras atualmente integram a rede?}

R: Nós temos um problema de números. Quando a gente assumiu, nós tínhamos um número de 120 emissoras, que integravam a rede, mas a gente sabe que tem mais que isso. Então, nós temos cinco grandes geradoras de conteúdo, cada rede gera um tipo de programa, que vai pra todas, que usam a mesma rede, para distribuir a sua comunicação e seus conteúdos. Então, basicamente se configurou esse fazer comunicação por 120 emissoras. Mas, se você me perguntar quantas emissoras católicas nós temos, não temos um número, porque tem rádios que são de congregações, tem rádios que são de dioceses, mas tem rádios que são de leigos, que têm programação católica. E, se a gente entrar no universo das rádios comunitárias, então, temos que multiplicar esse número. Então, nós temos um problema muito sério de estatística. A gente fale que temos em rede essas 120 emissoras, mas que, juntando outras emissoras que, de alguma forma, transmitem conteúdo nosso, temos 200 emissoras.

P: Inicialmente, o senhor havia me passado $300 \ldots$

R: Pois é. Nós temos um problema sério de estatística. Por exemplo, se envolver as emissoras comunitárias, só a rede do padre Reginaldo Manzotti tem mais de mil. Então, quando a gente fala em rede, emissoras que estão em rede mesmo, têm horário para entrar e sair, são 120 . Mas, rádios que, de alguma forma, transmitem conteúdo católico, podemos falar de 200 a 300 . Então, é uma coisa que, este ano, nós nos propusemos fechar esse número. Mas, tá nascendo rádio a todo instante, né? Nos últimos 10 anos duplicou o número de emissoras no Brasil, de rádio comunitária principalmente, então, nem se fala. E tem muita rádio comunitária que é católica.

P: Vocês têm ideia do percentual de rádios comerciais e educativas que integram a rede?

R: Esse é outro problema. Mas, das que a gente tem na rede, em sua maioria, cerca de $90 \%$, são comerciais. Mas são comerciais de fachada, porque, elas podem vender comerciais. Por exemplo, a Rádio Aparecida é comercial, a Rádio Canção Nova é comercial. Só que elas são comerciais tecnicamente, porém, na filosofia, elas não comercializam. Elas têm outras formas de sustentação. Então, lá no ministério, elas são comerciais, mas na prática, você pode vender ou não vender. Então, tem umas que optaram por vender e acredito que são a maioria, cerca de $90 \%$.

P: O que motivou a criação da rede e qual a missão dela?

R: A rede católica nasceu para comunicar os fatos da Igreja no Brasil. Nós não inventamos notícia. O nosso slogan é: "Fortalecendo a Igreja Católica no Brasil”. Porque hoje tu tens as outras mídias, que fazem um tipo de viés comunicacional. O nosso fazer católico não aparece nas outras mídias, porque ele é irrelevante. Porque, se tudo que existe, só existe porque é publicado, então, se os outros não publicam, nós não vamos existir, consequentemente nós não existimos. Então, nós passamos a existir e tudo o que for da Igreja, nós comunicamos. E não só missa, não. É também comunicar fatos da sociedade, destacando aquilo que tem a ver 
com o Evangelho, tudo o que for direitos individuais, justiça, cidadania, isso é Evangelho. Outra coisa, são pontos relevantes das razões da Igreja existir, são conteúdos, produção, se você pegar qualquer emissora da Igreja Católica, tu vais perceber que o que a gente produz são as razões da nossa existência. São programas especiais, que não estão vinculadas com as outras questões “do mundo”, vamos dizer assim, que as outras emissoras colocam aí. Mas nós produzimos a partir do que nos interessa, do que a gente acha que os católicos gostariam de ouvir. Claro que a gente usa pesquisas também, para produzir esses conteúdos.

P: Vocês têm, numericamente, um universo de ouvintes que vocês pretendem atingir?

R: Não, pelos mesmos motivos. Hoje, tudo passa pela questão econômica e as nossas rádios, elas são feitas por pessoas muito comuns, nós não temos muitos especialistas. E, nesse fazer comum, muitas vezes eles não usam pesquisas, eles vão no “achismo” porque é a relação pastoral. O fazer comunicação na Igreja não foge muito do fazer pastoral da própria Igreja. O fazer pastoral é como a Igreja se organiza dentro de uma comunidade. Então, de repente, uma comunidade, uma paróquia " $\mathrm{x}$ ” que organizou, ela se nutre das próprias pessoas e essas pessoas, elas não ganham salário para fazer isso. Elas são voluntárias, mesmo. São católicos que estão convictos da sua fé, que contribuem com a Igreja. É porque têm convicções, acreditam num grande projeto. Então, tem aquilo que a gente chama de palavra mística. É aquilo que nos move para que o Evangelho se perpetue na vida das pessoas.

No caso das rádios comerciais, eu tenho que estabelecer um diálogo com o pessoal da publicidade. Eu não posso estar escrachadamente levantando uma bandeira da fé. Eu tenho que fazer a coisa mediana, usar do jornalismo, porém, num viés que tenha a ver com os ideais da Igreja, mas um jornalismo extremamente ético. Eu não vou usar de fatos, de pessoas, não vou ter segundas intenções para colocar as pessoas no ridículo. Eu vou ser factual. Aconteceu um fato: "Nós estamos reunidos na Rede Católica etc. tem tantas pessoas...”. Isso é factual. Nas opiniões, aí, sim, eu vou ter várias vertentes de opinião, mas é extremamente profissional. Porém, na programação, vai aparecer a figura do padre, do bispo, da religiosa, lá pelas tantas, tem um programa específico, que é a missa dominical. Então, o sujeito mais intenso é a Igreja, mas é mais discreto, as pessoas sabem, por exemplo, muitas rádios que eu já tenho experiência, que são rádios totalmente comerciais, do Rio Grande do Sul, que são católicas, elas pertencem a uma fundação, são católicas por orientação, mas elas nunca dizem que são católicas, elas têm uma programação bem "do mundo", mas a abordagem, a linha editorial delas é muito clara: "Nós defendemos isso, isso e isso". "Não defendemos isso, isso, isso". Elas têm regras bem claras, porque têm que dialogar com o mercado, para poder se manter. Esse é o formato das rádios comerciais. Aí, tem rádios comerciais que não têm assim esse formato, são mais confessionais, eu diria. Por exemplo, a Rede Milícia é confessional, a Aparecida é confessional, as duas têm Nossa Senhora, vamos dizer assim, como o carro-chefe da programação e tudo é linkado com isso. Aí, são pessoas comuns que ajudam a sustentar um processo de comunicação. Então, elas se sentem assim: "Ah, eu também estou ajudando a evangelizar, com 50 reais por mês para ajudar um projeto”. 
P: Qual o papel do jornalismo nas emissoras católicas e como é possível fazer jornalismo, obedecendo aos cânones da objetividade, da isenção etc, dentro de uma instituição religiosa?

R: Ele não muda. Quem vai dizer isso é a pauta. Por exemplo, em que viés tu vais dar tal assunto. Vamos pegar aqui, por exemplo, choveu em São Paulo, alagou o Jabaquara. É jornalismo, um fato jornalístico. Que viés, uma rádio como a Jovem Pan, Band, Record vão dar? E que viés, nós vamos dar? Vamos noticiar o fato, porém, o entrevistado vai ter outro tom. Por exemplo, pegamos o fato "papa”. É um fato jornalístico. Se você fizer uma análise de como os meios de comunicação publicaram o fato "papa”, eu vou ter que assistir Globo, Band, Record, Aparecida, mais de um veículo para te contar o que realmente aconteceu com o papa. Então, quem vão ser as pessoas mais indicadas para falar do papa? Somos nós. Nós não vamos especular sobre a vida do papa, como muitas canais fizeram. Existiu um fato sobre uma figura emblemática, no universo social e religioso do mundo todo. Ele pedindo demissão do cargo, como é que fica? O que os outros meios fizeram foi futricar coisas que eu não sei nem de onde saíram. Nós jamais vamos abordar isso.

\section{P: Como vocês abordariam?}

R: A instituição, quem foi o papa, a história dele, a relação dos católicos com ele. Então, nós vamos respeitar a figura do papa e a crença como um todo, porque é uma questão muito mais abrangente, há uma questão ideológica que permeia o jornalismo, a gente sabe muito bem que é por aí. Peguemos a questão do Congresso Nacional. Nós não temos interesse que as pessoas tenham acesso a uma série de coisas. Por exemplo: corrupção é pecado, roubar, cometer falcatruas, além de pecado, é antiético. Nós não defendemos isso. Consequentemente, nós vamos fazer o quê? Os nossos meios vão fazer um jornalismo que denuncie esse tipo de ação. Por exemplo, no caso do presidente do Senado, o Renan Calheiros. Nós vamos criticar a história política dele, mas nós não vamos entrar na questão pessoal, individual dele. Nós não vamos lá “furungar” na família dele, se ele tem outro filho, não sei quê. Por quê? Por pior que ele seja, ele continua sendo um filho de Deus, uma pessoa que merece respeito e, se ele tem pecado, ele não está pecando sozinho. Existe uma construção desses pecados. Então, o nosso jornalismo, ele não personaliza. Ele não vai agir assim: “Agora, vamos pegar o presidente do Senado e vamos botar na cadeia e pronto”. Não, nós temos uma conjuntura que construiu a pessoa dessa forma. Então, nós vamos diluir. Se existe um pecado coletivo é porque existem pecados individuais, então eles vão ter que ser resolvidos de forma individual, para construir uma relação ética, comunitária, que passa a ser evangélica. Então, o nosso jornalismo, ele tem que estar fincado, calcado no Evangelho. A questão da relação humana, do respeito. Às vezes, a lei, ela pode ser a melhor do mundo, mas ela não é coerente. Então, nós vamos denunciar, de certa forma, isso. O nosso manual de redação é a palavra de Deus. O manual de redação do fazer jornalismo católico é a Bíblia, o Novo Testamento, o Antigo Testamento. É a partir do Evangelho que nós construímos, dentro do tempo, com uma reflexão - nós temos instituições como CNBB, Celam, uma série de documentos que regulam a nossa comunicação dentro do tempo que a gente está vivendo. A cada 10 anos, nós temos um documento. Nós tivemos o último documento, de Aparecida, que diz: "Você tem que fazer tal coisa". Mas você não tem 
que pegar o pescoço do presidente do Congresso e matá-lo. Então, assim. Nós temos que fazer uma comunicação que denuncie os processos de corrupção nacional. Então, nós vamos trabalhar isso e vamos construindo uma narração a partir do fazer a informação. Basicamente é isso.

P: E as rádios têm suas nuances, as suas diferenças. Como vocês lidam com isso?

R: Aí, nós entramos numa questão de linguagem, de universo de linguagem e na adaptação da rádio ao seu universo cotidiano. A verdade, ela á para todos. Porém, o código de linguagem, ele vai se adaptar a sua região, às diferentes regiões. Por que a gente se configurou em cinco redes? Podia ser só uma. Seria mais econômico do ponto de vista funcional. Teria uma rede, todo mundo contribui e ponto. Mas, quando a gente fez a rede, percebemos que o Brasil é hiperplural. Então, ficamos assim: cada rede vai falar com o seu público. Quando você escuta cada rede, você nota as diferenças. É muito sutil, mas, se você pega, por exemplo, a Aparecida. O sotaque da Aparecida, do pessoal do Vale do Paraíba. Ela é um pouquinho mineiro, um pouquinho paulista, é um pouquinho sertanejo, porque ela é feita pelas pessoas do local, então certamente a rádio vai ter a cara do local. Quando nós fizemos a rede gerada de Goiânia, imagina o sotaque de Goiânia chegando no Rio Grande do Sul. Era um horror. Imagina o carioca? Nós vamos ter problema agora na Jornada Mundial da Juventude, pois vamos ter um diálogo com uma rádio do Rio, com seus profissionais falando aquele “carioquês” para todo o Brasil. Mas, tudo bem. A gente sabe que é um evento local, ele é passageiro, vai ser gerado lá, mas o resto do Brasil estranha o "xis" do carioca, como o paulista estranha o sotaque do gaúcho e assim por diante. Então, o rádio tem esse viés de ser feito usando a comunicação que seja entendida no seu local.

P: As redes transmitem para uma determinada região, mas em alguns momentos, elas se unem em uma só programação?

R: E aí tem uma linguagem mais nacional. A gente tem um padrão nacional de comunicação. Ele é bem pasteurizado, digamos assim. Como, por exemplo, o Jornal Nacional. Os apresentadores não têm sotaque. Então, o nosso apresentador não tem sotaque. Ele fala uma linguagem bem brasileira, bem horizontal, isenta de sotaques.

P: E, quais são os produtos da Rede Católica de Rádio?

R: Nós temos o Jornal Brasil Hoje, e o Plantão RCR, que são feitos pela Rádio Aparecida, que é a nossa principal geradora hoje. Temos a Palavra da $C N B B$, que é feito pela Milícia da Imaculada e distribuído para todos, Igreja no Rádio, RCR em Debate e a Consagração a Nossa Senhora, que também são feitos pela Milícia.

O Jornal Brasil Hoje é feito em muitas mãos. A redação é feita em Aparecida, mas tem a contribuição das redes nacionais. O RCR em Debate, que é semanal, apresenta um fato que tenha sido destaque na semana. Nós vamos discutir um fato, por exemplo, o Senado, com entrevistados, especialistas, com diferentes opiniões, para que as pessoas possam construir a 
sua verdade. Como a Aparecida já tem uma infraestrutura, a RCR banca uma série de programas com os funcionários deles, a gente fez um acordo, e eles geram para todas as emissoras. Então, a Milícia produz Igreja no Rádio, Palavra da CNBB, RCR em Debate [na realidade, produzido pela Rádio Aparecida], Consagração e o Plantão. Então, todas as nossas rádios contribuem com a Aparecida para que ela faça essa produção para todos nós. Tem uma série de pequenos programas, que são gerados internamente para a sua rede. Então, existe uma rede macro, que tem essa grade, porém, cada rede tem a sua gradezinha específica, mas que pode trocar com outra rede. Trocar, porque a gente nunca vende.

R: Como a Rede Católica de Rádio atua na prática?

P: Cada rede tem a sua organização, tem o seu custo de produção. Ela vai produzir os seus programas e ela disponibiliza esses programas. Se hoje tu entrares no site da Rede Católica, tu vais ver uma série de podcasts, da nossa produção de conteúdos, que são compartilhados. Então, como funciona. Por exemplo, o Igreja no Rádio é produzido pela Milícia, é produto deles. Porém, numa atitude de cooperação, que é parte da nossa identidade, eles disponibilizam de forma gratuita. O Jornal Brasil Hoje também. Ele é produzido pela Aparecida, mas ele tem a contribuição de jornalistas do Recife, do Amazonas, na capital, São Paulo, Minas, que contribuem com as informações. Então, o jornalista contribui com o jornal, porém, a Aparecida não vai pagar pelo trabalho dele. É a minha contrapartida para fazer um grande projeto. Então, a gente vai construindo dessa forma. Nós temos cada rede e cada rádio, mas cada uma sabe que faz parte de uma igreja que comunga e partilha. Por exemplo, se você vai usar a bandeira da Signis Brasil, é “Construção de um Mundo de Paz”. O nosso slogan é "Fortalecendo a Igreja no Brasil.

R: A ideia é as maiores produzirem para as menores?

P: Sim, exatamente. Quem já tem uma história, inclusive de pessoal, financeira... nós não temos lucro, nós não temos sobras. O que sobra vai fazer com que o outro seja melhor também. Porque, se a comunidade está feliz, eu vou estar muito feliz também.

\section{P: Inclusive na venda de anúncio?}

R: Sim. Então, a rede católica, ela é uma entidade jurídica. Nós temos representantes comerciais, ele vai vender o comercial, todas as emissoras da rede vão passar esse comercial, então isso sustenta a nossa estrutura e eu vou partilhar depois com a emissora. Eu não vou devolver o dinheiro para ela, por ela ter passado o comercial lá. Eu vou conseguir ajudar uma rádio lá do interior do sertão, a se estruturar para ser rádio. Então, vamos trocar serviços de parceiros - hoje chamam de parceria, a gente chama da comunhão -, mas legalmente a gente faz todos esses trâmites jurídicos. A gente está trocando serviço, vai nota para lá e vem nota para cá. Juridicamente a gente faz essas coisas bonitinhas. Nós trocamos serviço e damos a infraestrutura, organização, assessoria. Então esse projeto permite que a gente possa que a 
gente possa contratar pessoas qualificadas para fazer com que as rádios se solidifiquem, para elas atenderem o seu objetivo de ser rádio e também fazer essa comunhão na prática.

P: Esse projeto se baseou em algum modelo, foi inspirado por algum modelo?

R: Aí tu vais ter que entrar na própria história da Igreja, de comunhão. E hoje se fala em rede social, rede social é um modelo mais antigo que andar para frente (risos). Desde que existiram três pessoas conversando, já era rede social. A partir do momento em que Jesus disse para os seguidores se reunirem em comunidade, pronto, foi montada a rede social. Então, a rede social não é do dono do Facebook. É de Jesus Cristo (risos). Quem inventou e registrou a marca rede social foi o dono do Facebook, porém quem inventou a comunidade foi Jesus Cristo. São Paulo foi o primeiro que teve a lógica da rede social, que construiu a lógica da rede social. Ele ia lá na comunidade, construía e replicava. Então, a rede católica tem esse modelo, essa estrutura. Já está no DNA, ela não consegue entregar outra coisa a não ser isso. Porque isso já deu certo há dois mil anos.

P: E também a questão das redes de rádio, que começaram a se constituir a partir dos anos 90.

R: Sim, nós tínhamos uma geradora principal, que multiplicaria para pequenas geradoras regionais, que, por conseqüência, expandiriam, então, internamente, nesse modelo. Só que a nossa rede consegue dialogar, temos as geradoras maiores, as geradoras menores, mas todas se comunicam entre si, continuamente. Essa é a lógica e o desenho da nossa rede. Cada uma tem a sua autonomia, jurídica e financeira, mas o escritório central, que quase que um conceito, é a rede católica. É uma articuladora. Então, o que realmente é a rede, é a Aparecida, a Rádio Imaculada Conceição, é a Nove de Julho, é a Rádio São Francisco, é a Canção Nova. Porque se você for ver, a Rede Milícia, ela não existe. Existe a Rádio Imaculada Conceição, uma entidade, que é a rede.

P: Em relação à Rádio Vaticano, vocês se inspiram naquele modelo de programação?

R: A Rádio Vaticano é a rádio oficial do Vaticano. É como se fosse a rádio oficial do governo, ela tem esse viés. É a porta-voz da comunicação do papa, transmite em várias línguas. Nossas redes utilizam o conteúdo da Rádio Vaticano, em alguns momentos a gente faz rede com eles também, porque é de interesse, interesse ideológico, e utilizamos notícias produzidas pela Rádio Vaticano.

P: O que caracteriza uma rádio católica? É a ideologia, é o fato de pertencer a uma entidade católica?

R: Tem rádio que não pertence a nenhuma entidade católica. Por exemplo, uma rádio do interior do Paraná, que é de uma pessoa, que se associa a uma paróquia, a uma instituição religiosa que se interessa em transmitir conteúdos da Igreja. Então, o fazer que caracteriza uma rádio católica é de que forma você vai fazer a sua comunicação. Ela pode ser católica e pode ser comercial. Ela pode não ser católica oficialmente, mas passar conteúdos católicos. Ela não é uma coisa pura. A Rádio Aparecida, ela não é católica. Ela é uma rádio comercial, 
porém, transmite mensagens que se identificam com o carro-chefe dela, que não é música pop mas é Nossa Senhora mais “pop” do Brasil, que é Nossa Senhora Aparecida (risos).

P: A Igreja tem uma longa tradição de utilização do rádio. Qual a importância que o rádio tem ainda para a instituição? Qual a importância do rádio para a comunicação católica?

R: Muita gente diz que o rádio morreu, mas é um ledo engano. Praticamente $90 \%$ da população do Brasil têm rádio. As pessoas hoje escutam rádio de alguma forma, de diferentes formas, mas sempre escutam de alguma forma. Usam um aparelhinho, não é mais um aparelho de rádio, mas é uma aplicação. Então, continua sendo rádio. O rádio é pano de fundo na vida das pessoas, que podem fazer coisas enquanto ouvem o rádio. $\mathrm{E}$ o rádio chega mais rápido, ele sempre chega mais rápido. Para a comunicação católica, então, nem se fala. Por exemplo, a CNBB tem um link direto com a diocese “ $\mathrm{x}$ ” lá do interior do Brasil, que, por conseguinte, tem as suas rádios locais. Então, o padre já vai saber no mesmo dia que aconteceu tal fato e ele vai passar a informação. Então, isso chega. Porque, hoje, querendo ou não, um universo muito grande de pessoas continua indo na missa, continuam acreditando na instituição Igreja, assim como continuam acreditando no rádio. Então, o que o rádio disse, o que o padre disse, é importante para elas. Porque o padre sempre vai defender as pessoas de sua comunidade. Ele sempre vai estar do lado delas, porque ele está morando com elas e ele vai se comunicar com o quê? Com o seu rádio local. Consequentemente, o rádio vai ser um aliado dele e as pessoas vão acreditar na rádio do padre. Hoje a influência do rádio é grande ainda, então nós utilizamos um meio credível, de fácil acesso, barato de fazer e rápido de chegar. Ele foi o primeiro meio de comunicação mobile que existiu, ele sempre foi móvel, você pode levar o rádio onde quiser. Então, o rádio tem essa facilidade. E hoje, com o advento da internet, mais ainda. Tu consegues estar em todos os lugares.

P: Vocês estão trabalhando muito com a internet, com o compartilhamento de informações via internet.

R: Muito pelo fato do rádio ser um conteúdo leve. Enquanto a televisão ainda está patinando, precisa de banda larga, de melhor desempenho, o rádio é muito mais fácil de disponibilizar. $\mathrm{O}$ rádio já está presente na internet há quase 25 anos. Vinte e cinco anos é um menino grande, já. Então, hoje, dá uma olhada no perfil das rádios no Facebook. O áudio está lá. No Twitter, o áudio está lá. No Youtube, o rádio está lá. Se não está ao vivo, tem o podcast. Então, assim, se as pessoas não têm tempo, eu vou poder entregar conteúdo para o seu tempo. Escute quando você quiser. Então, você vai observar que, nas 24 horas das pessoas, o rádio está sempre presente. Então, nos anos 80, quando se descobriu que as pessoas não dormiam mais à noite, começou-se a fazer rádio à noite. Daí, o rádio começou a ser 24 horas e, com o advento da internet, a gente percebeu que era dia de um lado do planeta e noite do outro e as pessoas estavam sempre escutando rádio. Então, hoje nós temos ouvintes em todos os cantos 24 horas. O pessoal diz: “Ah, porque o AM vai morrer”. Não, não vai não. O rádio sobrevive. Ele vai muito longe ainda. 
P: Na rede católica, vocês fazem também o site para as emissoras?

R: Sim. Hoje a rede tem uma fábrica de sites. Hoje, a internet está em todos os lugares. As pessoas estão na internet. Então, eu tenho que entregar o áudio para as pessoas que estão na internet. A rede católica se propôs a fazer exatamente isso. Dentro do conceito da troca de conteúdos, convergência de conteúdos Então, todas as nossas rádios podem ter um conteúdo de qualidade usando os conteúdos dos demais. Eu produzo conteúdo e disponibilizo, é a história da comunhão de novo. Eu faço aqui e você pode pegar e o outro pode pegar. Então, se uma rádio normal precisava de 200 pessoas para fazer rádio, hoje a rede católica tem no mínimo, de três a quatro mil produtores de conteúdos, de forma coletiva. A Igreja está em todos os cantos do Brasil, nós temos rádios em todos os cantos do Brasil. Consequentemente, tem uma cobertura nacional. Então, a dona Zequinha, lá no interior da Bahia, arrancou a unha num paralelepípedo. O Brasil inteiro vai saber, porque tem esses links. De novo, é a história da configuração da Igreja no Brasil, da estrutura dela. Nós somos rede. Então, nascemos com esse intuito: de a gente se ajudar, de a gente obter informação de lugares inusitados, onde, por exemplo, mesmo uma grande rádio de São Paulo não tem jornalista. Por exemplo, o incêndio em Santa Maria. Nós tínhamos uma rádio católica do lado do evento. A Rádio Medianeira, de Santa Maria, uma rádio católica, estava a 50 metros do evento. Noticiou em primeira mão.

P: Qual o principal desafio de fazer uma gestão integrada de rádio no Brasil e qual a realidade das rádios católicas hoje?

R: É complicado, porque, estamos vivendo um tempo atípico. Nunca na história nós tivemos cinco gerações juntas. Então, nós temos o pensar do menino de 20 anos e temos a resistência ideológica de uma pessoa de 80. Então, você imagina que o diálogo de um para o outro é muito complexo. Sem contar que, no meio, nós temos rivalidades, divergências geracionais terríveis. Aí, nós temos um mundo capitalista que briga a todo instante para você ser sozinho. Todo mundo têm que se virar. Nós temos um cenário que é individualista e nós estamos trabalhando no coletivo. É complicadíssimo fazer isso. Então, nós temos um espaço de diálogo no qual a gente decidiu: "Nós não vamos discutir as nossas diferenças, vamos discutir o que nos une”. E, a partir do que nos une, nós vamos nos estruturar. Então, nós vamos assim: “É possível fazer um Jornal Brasil Hoje? Então, nós vamos fazer um Jornal Brasil Hoje. Então, com o que nos une, nós vamos construindo, nós não temos grandes estratégias. Nós temos a realidade. A realidade faz com que eu consiga dar um passo de cada vez, então a gente vai dar um passo de cada vez. Porém, esses passos são extremamente sólidos. Esse fazer coletivo pode demorar décadas, mas eu vou ter que construir. De repente, tudo isso que a gente está plantando hoje, esse fazer coletivo, que é uma coisa muito recente, eu não vou colher resultados, minha geração não vai ver isso, mas, certamente, meus sucessores vão ver isso se tornar real. Então, a gente está plantando possibilidades. Foi com essa fórmula que o cristianismo se perpetuou e está se perpetuando

P: E como é que vocês lidam com as diferenças ideológicas, as diferentes correntes de pensamento que existem dentro da própria Igreja? 
R: Como é que uma sociedade consegue viver com diferentes partidos, com " $n$ ” partidos? A Igreja não é diferente. Nós temos um papa que nos une, nós temos um bispo que nos une e dali, pra fora, é um horror (risos). Então, a gente sempre tem algum ponto de convergência, sempre tem algum ponto que nos une. É de novo a história do comum. Então, nós temos um direito canônico, temos sempre algum documento que os bispos refletem e aprovam e depois outros que reinterpretam o anterior, ou seja, nós trabalhos com grandes balizadores. Porque a verdade... uma que ela não é nossa, ela não é sua, ela não é de ninguém. Cada um tem a sua verdade. Então, nós temos vários modelos de ver a Igreja dentro da própria Igreja. Lógico, que vai ter as suas tensões e cada período histórico vai ter um grupo desses que toma conta e vai moldando. Por exemplo, nas décadas de 1980 e 1990, nós tínhamos uma Igreja militante, histórica, antropológica. Hoje, nós temos uma Igreja mais introspectiva, mística e em com uma necessidade imensa de simbolismos. Então, eu continuo dialogando com eles. Eles não são estranhos nem nada. É como a sociedade. O fazer comunicação na Igreja não está dissociado da história. Se você vai olhar a história da Igreja e a história da sociedade, você vai ver isso. Então, é assim: se nós temos pecados internos, é porque os pecados estão ali fora. Dali eles vêm pra cá. Então, nós não somos diferentes. A única coisa que nós temos claro é que nós temos um Jesus que ressuscitou, que precisa ser conhecido. E que a verdade que está no Evangelho tem que ser comunicada, continuada. Esse é o nosso carro-chefe, essa é a nossa publicidade. Mesmo nas nossas diferenças, nós vamos permanentemente defender isso. É nisso que nós acreditamos. Nós somos a Igreja pecadora, fantástica, enorme. E nós somos um todo e cada um de nós é uma partezinha que faz esse todo hipercomplexo.

P: O senhor acredita que existam temas no jornalismo católico que não devem ser abordados, como por exemplo, as questões que são tabus ou temas sensíveis para a Igreja? Quais temas devem ou não ser abordados?

R: Vou falar do ponto de vista pessoal. Não estou falando como instituição, mas como jornalista. Eu acho que a informação tem que ser discutida. As pessoas que trabalham comigo sabem disso. Eu sou extremamente socializador de informações. Nós, enquanto meios de comunicação da Igreja, nós temos que fazer o quê? Socializar a nossa posição. Então, acredito que todos os tabus têm que ser discutidos. Então, a verdade, ela tem vários lados. Logicamente, que não vai ser assim, o meu meio de comunicação que vai falar: a Igreja é contra o uso de camisinha. Vai ser o papa, vai ser o bispo que vai dizer isso dentro do meu meio de comunicação. Como vai ter o ativista que vai dizer que nós estamos errados. Tudo bem. Logicamente que, ao fazer jornalismo, aí entra nos vários níveis de concepção que as pessoas têm do jornalismo, do fenômeno comunicacional. Nós temos vários tipos de entendimento do cristão. Mas eu sou um grande defensor da verdade e acho que tudo deve ser abordado. Mas, depende do âncora, do editor e das fontes que vão ser colocadas para discutir o assunto. Então, os meios de comunicação não têm a verdade absoluta. Eu vou colocar A, B, C e D e você resolve o seu problema. Então, estão as informações aí para você tomar a decisão. O meu meio nunca vai tomar a decisão. O jornalismo leigo que está aí não modifica do nosso. Porém, nós temos que entender que determinados meios não vão abordar determinados assuntos. Por exemplo, o casamento gay. Nós estamos dentro de uma sociedade 
em que as pessoas estão discutindo isso. Consequentemente, a gente vai discutir isso. Só que a gente tem que discutir isso com técnicos, com pessoas que entendem do assunto, com sociólogos, com políticos. Porque nós estamos vivendo numa sociedade cada vez mais diversa e complexa. Então, assim, todos são filhos de Deus. Então, nós temos que olhar para todos. E muitos meios nossos abordam isso. Os que não são confessionais abordam com a maior tranquilidade do mundo. Então, o respeito às diferenças tem que existir. Só não vamos fazer apologia, nem perseguição. Porém, pode ter dentro da própria estrutura da Igreja movimentos, meios até homofóbicos, mas não são a Igreja, são pessoas que se dizem católicas, ou cristãs, que defendem isso. Então, as contradições que nós temos são as contradições do mundo. E nós não somos diferentes. Então, eu [mostra as secretárias da sede da RCR, no Jabaquara, em São Paulo], Ângela, Helena, de onde nós saímos? De uma sociedade leiga. Então, o ambiente interfere e me contamina, vamos dizer assim. $\mathrm{O}$ ambiente influencia e eu não posso negar que estamos vivendo um período histórico, de grandes inovações e pensamentos. Nunca as pessoas tiveram tanta liberdade. E como é que vou trabalhar se, no passado, a gente tinha regimes autoritários? Eu tenho que ajudar as pessoas a entender essa liberdade. Ontem, eu até ouvi uma frase de um jovem no Twitter, que me chamou a atenção: "Liberdade é pouco. O que eu quero não tem nome”. Eu achei impressionante isso. Os adolescentes não estão entendendo nem o que é liberdade. Então, temos que puxar por aí. Os jovens não estão entendendo o que é liberdade. 


\section{APÊNDICE H}

Entrevista com Dom Dimas Lara Barbosa, presidente da Comissão Episcopal Pastoral para a Comunicação da Conferência Nacional dos Bispos do Brasil (CNBB), realizada no dia 9 de fevereiro de 2013, em São Paulo.

P: A Comissão Episcopal Pastoral para a Comunicação foi criada em 2011, sendo desmembrada da antiga Comissão Episcopal Pastoral para a Cultura, Educação e Comunicação Social. Quais os objetivos da nova comissão?

R: Isso eu posso, inclusive, te arranjar por escrito, porque é uma lista bastante ampla de uns 20 itens, que foram aprovados em assembléia. Quer dizer, ao se criar a comissão, já se aprovou o número de bispos que deveria constituí-la - somos três bispos - e o número de assessores - são dois assessores e, depois, também já se aprovou o elenco das competências da comissão. Mas o fato é que a principal motivação foi que a antiga comissão, que era comandada por dom Orani [João Tempesta, arcebispo do Rio de Janeiro] acumulava Ensino Religioso, Cultura, Educação e Comunicação. Então, pelo menos a Comunicação ganhou a sua independência. E não foi só a Comunicação, mas a Juventude também ganhou independência: antes era parte da Comissão para o Laicato. Então, nesse sentido, eu acredito que, nos últimos anos, a CNBB tem crescido na consciência da necessidade de investir mais na comunicação e na formação de comunicadores. Então, a comissão nasceu sobretudo com esse objetivo, de ser fomento das iniciativas comunicadoras da CNBB. O objetivo maior, o ideal, seria conseguir que a comunicação, não a Pastoral da Comunicação, mas que a Comunicação fosse realmente um conceito, um pano de fundo, algo transversal de toda ação da Igreja. E a irmã Élide [Folgolari, religiosa paulina, assessora de imprensa da CNBB] que cuida dessa missão, sobretudo da Pastoral da Comunicação. O padre Clovis [Andrade de Melo, assessor da Comissão Episcopal Pastoral para a Comunicação] também foi convidado a implantar toda a rede de informática da Igreja no Brasil. Já existe, em nível de América Latina, há muitos anos, quando eu era assessor da CNBB já existia a Riial, a Rede de Informática da Igreja na América Latina, mas que nunca “pegou” no Brasil - era uma iniciativa do Celam [Conferência Episcopal Latino-Americana] -, por causa da diferença de línguas, quer dizer, a Riial, sendo conduzida, coordenada, mais especificamente, na Argentina, ela não conseguia "apreender” a realidade brasileira. E, mesmo a Riial, ela nasceu, num primeiro momento, para tentar implantar na América Latina, o Office Eclesial, que também no Brasil, não chegou a haver a convergência. Hoje, naturalmente, com o desenvolvimento das mídias sociais, das redes sociais, me parece que o papel de uma rede de informática da Igreja, seja no Brasil, seja na América Latina, amplie muito as suas finalidades no sentido de despertar a consciência para um trabalho de rede ou em rede. 
P: Existe na CNBB uma estratégia de comunicação integrada?

R: Nós agora, e é esse o objetivo desta reunião [de que o arcebispo participava em São Paulo, no dia 8 de fevereiro de 2013], agora é que nós estamos conseguindo dar os passos mais decisivos para a elaboração de um diretório da comunicação da Igreja no Brasil, porque ele ainda não existe, mas, se Deus quiser, deverá estar aprovado na Assembleia de Aparecida, agora em abril. Mas é um sonho antigo, dom Orani trabalhou nessa ideia, que já vem de, pelo menos, oito anos. E, da mesma maneira, ficando apenas no âmbito das TVs: cada TV tem uma linha editorial, recursos diferenciados, por exemplo, a Rede Vida é uma TV comercial, mas a maioria das outras são TVs educativas, depois, no caso da Canção Nova, ela pertence a uma comunidade específica, que tem uma espiritualidade marcadamente carismática, enquanto a Aparecida, ao mesmo tempo que pertence ao santuário, mas que, sobretudo, os redentoristas dão outro “tom”, então, essa diversidade trazia muita dificuldade de um trabalho orgânico entre as TVs. Dom Orani reunia-se e eu continuo me reunindo periodicamente com todas as TVs católicas, mais a RCR [Rede Católica de Rádio], mais alguns portais, para tentar discutir problemas comuns. Então, para grandes iniciativas, até se consegue fazer um trabalho em conjunto, como a Campanha da Fraternidade, a Assembléia dos Bispos, a vinda do papa agora para a Jornada Mundial da Juventude. Tem um programa chamado Igreja no Brasil, que é replicado em todas as redes, mas entrar em cadeia em situações ordinárias, que eu me lembre, só aconteceu uma vez, quando o papa estava sendo muito agredido, por causa da situação da Irlanda, então, nós propusemos às TVs católicas e dom Geraldo [Majela] fez um pronunciamento em rede, em cadeia nacional. Mas, agora, graças a Deus, houve consenso, de que fosse criada a Rede Católica de TVs, à luz da RCR. Eu acho que isso já é um bom avanço, mas ainda tem muito a ser feito. Quando se fala de comunicação integrada, a coisa fica muito pior. Eu me lembro que, quando eu era secretário-geral da CNBB, eu percebia que, mesmo os bispos estando reunidos em assembleia, eles aprovavam uma nota, aprovavam uma mensagem, aquela nota não era repercutida em boa parte dos informativos das próprias dioceses dos bispos que ali estavam. Então, o objetivo da Riibra é começar a criar essa consciência da necessidade de um trabalho em rede e de uma comunicação integrada efetivamente. Então, eu diria, ainda não existe essa prática no Brasil. Um dos objetivos que a comissão se propõe é tentar criar essa mentalidade.

P: Em relação às rádios, quais diretrizes estão sendo adotadas?

$\mathrm{R}$ : As rádios já conseguem fazer cadeia. Através da RCR, elas se ajudam muito, de modo que rádios grandes produzem programas que depois, não necessariamente em cadeia, são usados pelas rádios menores. O padre Eduardo Dougherty [fundador da Associação Senhor Jesus, de orientação carismática] gosta muito da idéia de criar um banco católico de programas. Isso ainda não existe, mas, algumas produtoras, como a Rádio Aparecida, por exemplo, ela ajuda muito as rádios do interior, que não têm conteúdos para transmitir. Então, eu parto do pressuposto que o trabalho com as rádios já está relativamente avançado. Mas, o diretório não entra nesse nível, porque quem deve fazer, ou definir a forma como de como vão trabalhar são as próprias rádios e elas já têm a RCR, as eventualmente poderão rever seus próprios estatutos 
conforme as necessidades dos tempos. Agora, quem está tentando elaborar uma minuta de estatuto são as TVs, para se criar a Rede Católica de TVs. Nós, da CNBB apenas catalizamos esse trabalho. Tem uma coisa que é muito importante de dizer: a CNBB não é uma instância hierárquica no Brasil. É uma instância de articulação e serviço. É perfeitamente possível que um documento seja aprovado em assembleia e o bispo chega a sua diocese e diz: "Está aqui, ele não vai entrar e pronto”. A menos que seja facultado diretamente pela Santa Sé, em alguns casos especiais, que a CNBB, por decreto, imponha uma norma para todo o Brasil. Quando eu era secretário-geral, eu cheguei a assinar alguns decretos, como por, exemplo, o Diretório para os Diáconos Permanentes. São textos que foram aprovados pela assembleia, depois enviados para a respectiva congregação, fizeram as alterações sugeridas, o placet e, aí sim, a CNBB, a presidência da CNBB, faz um decreto e ele se torna norma para todo o Brasil. De outra maneira, não. A nossa comissão, por exemplo, de novo, é uma comissão para articulação e serviço. Nós não temos como impor, o que não deixa de ser um elemento dificultador, mas que também tem suas vantagens. Se você toma, usando uma comparação de uma outra rede, uma rede confessional, mas não-católica, por exemplo, a Record. Como ela é de um único dono, aquilo que ele determina se cumpre em todos os níveis, inclusive nas, chamemos, sucursais, ou nas variantes, do tipo revista, jornais, rádios, aquilo que houver e que fizer parte da rede. No caso da Igreja Católica não é assim. Ela não é dona, não existe um único dono. Então, o que a gente faz são diretrizes. E diretrizes normalmente são grandes princípios, são grandes orientações, mas que depois têm que ser recebidas pelas dioceses, pelas igrejas locais. Então, nesse sentido, a chance que a Igreja Católica tem de trabalhar em rede, ela se dá muito mais pelo convencimento, pela autoridade moral da CNBB ou, eventualmente, quando, efetivamente temos uma orientação explícita da Santa Sé. Mas sem que, juridicamente, haja um elemento de força, da Justiça Civil, que possa questionar uma rádio porque ela transmitiu isso ou aquilo.

P: Ou seja, a programação fica a cargo da própria rádio.

R: Sim, da própria rádio. Comunhão e participação. É uma expressão bonita, mas de difícil aplicação num sistema competitivo e mercadológico como é o nosso. E, de novo, se você tem uma empresa única, com modelo piramidal, mas, se não é assim, mesmo nas redes sociais, você pode ter hoje cinco mil seguidores no Twitter e, de repente, ser abandonado pelos seus seguidores. Você pode ter novos e eles vão continuar ali enquanto o que você for interessante, enquanto o que você disser significar alguma coisa, ou para ser criticada, ou para ser seguida. Mas ninguém obriga outro a segui-lo.

P: Quais os maiores desafios da, assim chamada, nova evangelização pelos meios de comunicação atualmente?

R: A ideia de uma nova evangelização aparece pela primeira vez na literatura latinoamericana num subsídio após a Conferência de Medellín. Medellín teve a finalidade de receber criativamente o Vaticano II na América Latina. Mas a expressão ganhou força com João Paulo II, que inclusive, no México, falando na abertura da Conferência de Puebla, ele 
disse que era preciso apostar numa nova evangelização. Depois, em Santo Domingo, essa idéia volta. E, agora, mais recentemente, o papa Bento XVI criou, na Cúria Romana, um Pontifício Conselho para Promoção da Nova Evangelização. Naturalmente que, em termos mundiais, essa nova evangelização adquire conotações muito diversificadas e eu tive, em nome do Celam, de participar em 2011, de uma assembleia do conselho das Conferências Episcopais da Europa, são 44 países, se não me engano, e essa reunião foi em Tirana, Albânia, e, na ocasião, o tema principal era recolher as sugestões que todas as conferências - e lá, nós tínhamos Rússia, Bielorrússia, passando pelos Balcãs, Lituânia, Estônia, Eslovênia e toda a Comunidade Européia..., aliás, é interessante contar que, em termos de organização, existem duas entidades diferentes na Europa, enquanto na América Latina só tem o Celam, eles têm o Comece, que reúne os países da União Européia, só. Então, o Comece, representando esses países do ponto de vista da Igreja Católica, eles têm presença no parâmetro europeu e na Comunidade Europeia, digamos assim. Então, você pode fazer lobby, encaminhar sugestões e tudo o mais, enquanto que o CCEE, não, ele é só pastoral e ele inclui a Grande Europa, inclusive Rússia, que aí, nesse caso, entra como associada porque uma parte, existem alguns países, como o Casaquistão, que metade é asiática e metade é europeia. Então, já naquela ocasião, se tratava de recolher o que cada país pensava da nova evangelização. Para mim, foi um aprendizado muito bom e, naturalmente, no Celam, nós fizemos a mesma coisa com os países da América Latina. E, no Brasil, que já é um continente, é uma coisa você fazer evangelização na Amazônia, São Paulo, no meu Mato Grosso do Sul... Então, objetivos principais no Brasil: são mostrados nas Diretrizes 2011-2015 [da CNBB], que mostram aquelas cinco “urgências”. Aquilo, basicamente, é o que marca os passos de todo mundo. O que isso significa para a Pastoral da Comunicação é: presença, linguagem, o trabalho de evangelização mais diretamente pessoa a pessoa, você consegue entrar na casa e falar com cada fiel. Por exemplo, em Campo Grande, eu estou tentando desenvolver uma metodologia que já é usada, por exemplo, pela TV Século XXI, de ter um banco de dados, de tal maneira que eu possa me comunicar diretamente com os catequistas, com os ministros, sem precisar mandar aviso através das paróquias. Então, de uma forma personalizada. Eu desenvolvi um costume que deu certo, de estar mandando spots de um minuto, para ser passados em data show, ou onde não houver data show, no áudio, por ocasião da Campanha para a Evangelização, Campanha da Fraternidade, e ontem, eu mandei um, a pedido inclusive do próprio secretário de Saúde, em que eu conclamava o povo a juntar as forças no combate à dengue, já que a epidemia lá está muito grande. É uma forma concreta de você falar diretamente em todas as paróquias, em todas as comunidades, em todas as missas onde você não pode estar. Articulação e o aproveitamento de uma força criativa, que é realmente maravilhosa e que está escondida sobretudo da parte da juventude, que quer apostar a vida numa uma causa pela qual valha a pena viver e morrer, mas que, muitas vezes, não tem chance.

P: As rádios católicas ouvidas em entrevistas afirmam que tem por objetivo evangelizar pelos meios de comunicação, inclusive no jornalismo. Aí surge uma questão: como é possível fazer 
jornalismo, seguindo os cânones e preceitos sobre a objetividade, a isenção, imparcialidade, numa instituição que tem suas posições ideológicas claramente definidas, como é o caso da Igreja Católica? Como é possível fazer um jornalismo evangelizador sem ser proselitista?

R: É curioso, mas me lembro de um livro já de edição esgotada do Hilton Japiassu, O Mito da Neutralidade Científica, em que a própria ciência era questionada numa de suas qualidades mais caras, a da neutralidade, na questão dos paradigmas e depois não só isso. Edgar Morin, em Ciência com Consciência, vai mostrar que, muitas vezes, o cientista desenvolve o conhecimento, mas o banco de dados desse conhecimento não pertence ao cientista. Ele pertence a grupos econômicos e políticos, de modo que, o que define a pesquisa científica nem sempre é a neutralidade da busca do conhecimento como tal, mas são interesses econômicos, ideológicos ou de outras naturezas, e, inclusive propugnando, Edgar Morin, que a ciência deveria andar de mãos dadas com a própria ética. Exemplo: a usina atômica é possível? É. É ético? Aí está uma questão. Você fazer o genoma humano é possível? É. Você usar o genoma, como um banco de dados para serviços de planos de saúde e seguradoras de modo que você, conforme o seu genoma você não vai conseguir fazer um plano de saúde ou seguro porque você é “mercadoria estragada”? Aí é um outro questionamento. Passando isso para o jornalismo, os jornais. Não existe jornalismo neutro. Infelizmente, essa é uma grande verdade. Cada jornal tem a sua ideologia. Os mesmos jornalistas muitas vezes veem os seus títulos mudados pelo editor. E esses títulos dão uma conotação que nem era talvez o que o próprio jornalista queria colocar. Mexem nos títulos dos articulistas. Sei por experiência própria porque muitas vezes me pedem artigos, mando com título e mudam o título, por outro que eles acham melhor, mas muitas vezes desfocando aquilo que a gente efetivamente queria dizer. Então, tomando os grandes jornais, como o Jornal Nacional, por exemplo, não é qualquer matéria que você consegue introduzir lá, mesmo que você tenha amigos dentro da Rede Globo, etc. porque existe uma linha editorial, que vai dar ênfase a determinados tipos de temas, e outros vão deixar despercebidos. Por exemplo, os movimentos sociais: quais são os grandes jornais que efetivamente tomam posição em defesa dos movimentos sociais? Normalmente, é de demonização dos movimentos sociais, independente de sua matriz ideológica do movimento social.

Agora, falando especificamente do jornalismo católico. É possível você evangelizar através do jornalismo? Sem dúvida alguma. Tudo que você faz com base na ética, na verdade, no diálogo, dando visibilidade às lutas sociais do povo, denunciando, promovendo os direitos humanos, isso é evangelização. A evangelização não é só quando você faz um anúncio formal da pessoa e da obra de Jesus Cristo, mas quando você promove os valores do Evangelho. Então, um âncora, ele pode perfeitamente ser um arauto da ética, de valores que são profundamente humanos, sem mencionar em nenhum momento um documento da Igreja, um magistério do papa ou mesmo uma citação bíblica. Naturalmente, o jornal vai ter também a sua linha editorial. Ele vai assumir determinados temas, que podem até ser temas comuns da grande mídia. Eu acho que o jornal de uma rádio ou da imprensa católica também participa, comenta, escreve, opina sobre os mais diversos temas. Às vezes, nós somos surpreendidos com pedidos de entrevista que a gente fica assim... eu lembro quando eu era secretário-geral 
da CNBB e também bispo auxiliar do Rio de Janeiro, houve um ano em que o Carnaval caiu muito cedo, praticamente era fevereiro e já tinha Carnaval. E houve uma mobilização da rede hoteleira do Rio, porque eles sentiam que, naquele ano, o movimento tinha caído muito, porque veio o Révellion e, logo em seguida, férias e o Carnaval. Então, eles queriam saber a opinião da Igreja sobre a possibilidade de fixar a data do Carnaval, porque, como o Carnaval é ditado pela data da Páscoa, que é marcada em primeiríssimo lugar pela primeira lua cheia da primavera na Terra Santa, a partir daí, no domingo seguinte é a Páscoa católica, a primeira lua cheia é a Páscoa Judaica, quarenta dias antes, Quarta-Feira de Cinzas. Aliás, uma semana antes, o Domingo de Ramos é o começo da Semana Santa, e Quarta-Feira de Cinzas são os três dias anteriores ao Carnaval. Então, é muito curioso que a data do Carnaval seja marcada, digamos assim, a partir da religião. Eu dei a minha opinião na época, acho que não vale a pena aqui, mas o que chamou a atenção é que eu recebi um telefonema do Wall Street Journal, que queria uma entrevista sobre esse tema. Eu brinquei na época: "Espero que a minha entrevista não vá fazer cair a Bolsa de Nova York”. Quer dizer, muitas vezes o tema da religião interessa ou tem repercussões para além dos limites da Igreja. Mas, sobretudo, os grandes temas humanos da política, da ética, da economia, das relações familiares, justiça e paz, saúde pública, que são temas inclusive abordados pela Campanha da Fraternidade, esses temas são recebidos tranquilamente nos parlamentos, não só no Congresso Nacional, mas também nas câmaras, assembléias, porque são temas que dizem respeito à sociedade como um todo. Então, acho que, da mesma maneira, o jornalismo cristão pode ser evangelizador, pela linha editorial, pelas defesas que faz da dignidade da pessoa humana, dos próprios valores evangélicos, mas sobretudo pela ética, verdade, respeito também ao contraditório etc.

P: Mas existem temas tabus? O que não deve ser abordado, na sua opinião? Como abordar temas delicados também, como o da Irlanda, conforme o senhor mencionou?

R: Qualquer instituição que esteja envolvida em um escândalo, numa agressão midiática quando eu falo "agressão midiática” entenda o consenso dos meios em relação a sua própria posição - ela vai buscar assessoria sobre como se posicionar de tal maneira que ela não fira as regras da ética e, ao mesmo tempo, não se omita. Então, eu cito um exemplo muito concreto, que eu vivenciei - acho que eu nunca apanhei tanto da mídia, mas tanto, tanto, tanto (risos) quando houve a votação pelo Supremo Tribunal Federal, da lei da, assim chamada, biossegurança. Era a questão da experiência com os embriões. Olha, era praticamente, impossível você conseguir plantar alguma coisa num grande jornal que, pelo menos, deixasse a gente expor os motivos pelos quais nós éramos contrários à manipulação de embriões, já que nós acreditamos que a vida começa com a concepção. E um detalhe muito importante: a Igreja não diz que a vida começa na concepção por causa de um dogma religioso. É por causa da própria Ciência. Foi a própria Ciência, a boa Ciência, que nos convenceu dessa verdade. O que nós aprendemos, sim, é valorizar da dignidade da pessoa humana, em qualquer circunstância em que ela esteja vivendo, porque ela é imagem e semelhança de Deus. A imagem e semelhança de Deus é um elemento religioso, mas a pessoa humana não precisa ser um elemento religioso. Tanto que a Declaração dos Direitos Humanos não foi motivada por fundamentação religiosa. Mas, muitas vezes, é muito difícil. Você, pelo simples fato de ser 
porta-voz ou professar uma determinada confissão religiosa, sobretudo católica, muitas vezes é quase impossível que você não seja acusado de estar querendo impor princípios religiosos, mesmo quando você fala de ética, de honestidade etc.: "Lá vem a Igreja querendo se impor". Então, muitas vezes, nós católicos somos tratados como cidadãos de segunda categoria. Mas, naquela ocasião, e ainda hoje, é muito raro que um jornal tenha a honestidade de separar células-tronco embrionárias de células-tronco adultas. E dizem: “A Igreja é contra o uso de células-tronco”. E não é verdade. Não é verdade. Ela é contra a manipulação de embriões. E outra coisa: com todas aquelas promessas que fizeram, até hoje, passados já vários anos da votação da lei, não existe nenhum protocolo científico sério, com resultados adequados de embriões. Existem sempre de células-tronco adultas. Então, naquela ocasião, foi uma malhação geral, assim de primeiras páginas, e a gente sendo acusado de ser contra a vida e levaram os cadeirantes ao Supremo e diziam: “A Igreja é contra nós”, e por aí vai. A única maneira que nós descobrimos, e com uma assessoria da CDN, Companhia de Notícias, foi de promover um debate com cientistas, inclusive, não necessariamente católicos, mas que efetivamente tinham uma visão parecida com aquela que nós estávamos defendendo, feita num auditório de uma universidade leiga e sem nenhuma presença de qualquer pessoa religiosa ali. Aí se ganhou algum espaço, que, logo depois, foi abafado por outros mais. Então, eu não acho, pelo contrário, que a Igreja deva se omitir diante de temas delicados. Ela deve, inclusive, dar a cara a tapa, mesmo que tenha que apanhar e ser muito criticada pela sua própria defesa da vida ou de outros princípios em que acredita. O que talvez falte, isso sim, mesmo nos profissionais que trabalham nos meios católicos é a devida competência para abordar determinados tipos de temas. Quando eu ainda não era secretário-geral da CNBB e estava no Rio de Janeiro, houve uma situação muito curiosa. Dom Odilo é que era secretáriogeral, na época, e o Fantástico ia abordar o tema da anencefalia e queriam que alguém da Igreja fosse à internet para o chat - que não é um chat de 40 pessoas (risos). Então, na época eu disse: "Bom, o ideal é que fosse uma mãe-médica, porque ela iria poder falar como mulher, como mãe e como profissional. Eu não consegui a médica, mas consegui um professor de Medicina da Universidade Federal Fluminense. Depois eu disse para o Erlanger, o diretor da Globo: “Vocês deram um 'furo' naquele dia”, porque ele foi ao chat, foi a oportunidade de falar com competência para um público que, não necessariamente frequenta as nossas igrejas e, com toda a firmeza. Mas o "furo" da Globo foi que eles não mudaram o nome. Então, as pessoas perguntavam para o dom Dimas e quem respondia era o professor de Medicina. Então eu brinquei, na frente do diretor da Globo, no Mutirão de Comunicação [realizado no Rio de Janeiro, em julho de 2011]: “Arrasei na Medicina naquele dia”. E o comentário era esse mesmo. Então, aqui, em São Paulo, eu participei, uns anos atrás, de um seminário no ICS [Instituto Internacional de Ciências Sociais], que se chamava Informação Religiosa com Qualidade, onde se exortava os jornalistas da grande mídia a conhecerem efetivamente o objeto do qual vão tratar. Porque a gente percebe, quando de repente aparece uma crítica cega à Igreja em um tema que não tem nada a ver, você pode saber que é pauta vazia. Então, o cara não tem com que preencher lá o seu caderno, vai lá nos arquivos, arruma alguma coisa... e ainda ontem eu ouvia - pode parecer piada, mas é verdade - de um comentarista que disse que o papa agora iria "incinerar" todos os presentes, em vez de "incensar", imagina. Eles 
trocam tudo. Então, informação religiosa com qualidade. E, para os jornalistas católicos - aí houve um segundo, logo em seguida -, era justamente como conhecer profundamente a própria realidade da Igreja, o seu pensamento, para poder, com competência estar enfrentando os grande debates, não só na mídia, mas também nos meios universitário, culturais etc. com competência. Esse é o grande desafio. Então, o jornal deve abordar temas polêmicos? Deve. Mas, se ele quer ser fiel à Igreja, ele tem que ter estrutura para não manipular os dados, não se omitir, dizer claramente qual é o pensamento, mas dando as razões pelo que faz. Mas, evidentemente, se se trata simplesmente de divulgar e não de comentar - porque o âncora que faz esse papel de comentarista -, de novo, a linha editorial, ela deve, sim, abordar temas polêmicos e a própria competência vai ser o elemento maior para que a evangelização aconteça, inclusive quando a gente não é politicamente correto. 


\section{APÊNDICE I}

Entrevista com José Marques de Melo, diretor titular da Cátedra Unesco/Metodista de Comunicação e professor emérito do Departamento de Jornalismo da Escola de Comunicações e Artes da Universidade de São Paulo. Realizada no dia 12 de março de 2013, em São Paulo.

P: Como o senhor vê a comunicação da Igreja Católica hoje. Quais são os maiores desafios e maiores obstáculos dessa comunicação?

R: Durante muitos séculos a Igreja adotou uma posição conservadora em relação aos meios de comunicação. Não sei se a palavra retrógrada seria a mais adequada, mas ela foi realmente apocalíptica, porque, depois do surgimento da imprensa, ela criou uma série de mecanismos de defesa que redundaram na Inquisição. E a Inquisição foi alguma coisa brutal porque significou não apenas censura aos livros, mas também censura aos autores. O fogo que queimou os livros queimou também muitos autores. A Igreja só mudou no século 20. Foi uma mudança gradativa, que tem muito que ver com o desenvolvimento da mídia eletrônica, que a Igreja não dominava. Em segundo lugar, tem que ver também com o avanço das igrejas evangélicas, que usavam principalmente o rádio e a televisão e a Igreja Católica estava ausente desse processo.

Estamos completando este ano 50 anos do decreto Inter Mirifica, que foi a grande mudança do Concílio Vaticano II, convocado pelo papa João XXIII, e abriu uma clareira nesse ambiente todo. Criou novas possibilidades e revalorizou o papel da mídia. Então, hoje realmente há uma diferença muito grande porque são 50 anos em que a Igreja se abriu para os meios de comunicação e os vem usando intensamente, não da maneira que talvez devesse estar usando, porque cinco séculos não é coisa que se mude em 50 anos. Dois papas foram fundamentais para isso: o próprio papa João XXIII, com aquela bondade de camponês que ele tinha, ele, não verdade, fez uma revolução na Igreja, não só na comunicação, mas em tudo, com o Concílio Vaticano II, e João Paulo II, que talvez tenha sido o papa que mais valorizou os meios de comunicação. Ele próprio era um homem que tinha formação comunicacional, do teatro - ele foi ator - e, na verdade, ele desempenhou um papel, que era do "papa notícia”. O fato de ele ter percorrido o mundo inteiro, a presença dele em várias partes do mundo, significou a abertura da Igreja para o mundo não-romano.

P: A questão das diversas correntes de pensamento dentro da Igreja, o senhor acha que representam um obstáculo para uma comunicação mais efetiva?

R: Essas questões de natureza teológicas ou ideológicas, acho que não são tão importantes no campo da comunicação. Você pode ter católicos fervorosos que entendiam o papel da comunicação, como o frei Leonardo Boff, quanto pode ter também padres ou freiras que não eram tão avançados assim, mas que valorizavam a comunicação também. Acho que esse não é 
o elemento fundamental. A verdade é que tem congregações que abraçaram o mundo das comunicações, como as paulinas, várias congregações que abraçaram a comunicação como missão, e outras que são mais espiritualizadas, que também buscam o uso da mídia para a evangelização, e outras que são mais refratárias ainda.

P: As rádios analisadas na pesquisa dizem ter toda a sua programação voltada para a evangelização, inclusive o jornalismo. O senhor acha que é possível obedecer aos cânones do bom jornalismo, como objetividade, veracidade, isenção, multiplicidade de fontes, dentro de uma instituição, como é o caso das emissoras católicas?

R: Acho que sim. Não vejo dificuldade nenhuma. Aliás, a minha relação com o tema Comunicação na Igreja se deu de maneira, que eu diria, surpreendente. No fim dos anos 60 e início dos anos 70, quando nós criamos a Escola de Comunicações Culturais, eu fui procurado por duas pessoas influentes da comunicação da Igreja, que era o frei Romeu Dale e irmã Benedicta Idelfet, que eram membros do Secretariado de Opinião Pública da CNBB, e eles estavam preocupados com o comportamento dos bispos. Os bispos daquela época eram muito refratários aos meios de comunicação e esses religiosos, que trabalhavam com Bíblia encontravam muita dificuldade em se relacionar, até porque colocavam muitas barreiras, muitas dificuldades. Nessa ocasião, quem dirigia o Secretariado de Opinião Pública era dom Avelar Brandão, o cardeal primaz da Bahia, que havia sido arcebispo de Pernambuco, Teresina, e dom Avelar Brandão realmente abriu as portas para a comunicação. Então, eles me procuraram, lá na Cásper Líbero, onde eu dirigia o Centro de Pesquisas da Comunicação Social, porque a Cásper Líbero, não sei se você sabe, foi originalmente vinculada à PUC, Pontifícia Universidade Católica. Depois, ela se desvinculou totalmente e não tem mais nada a ver com a PUC. Ela é uma escola particular autônoma. Então, naquela ocasião, eles me procuraram e disseram: "Nós queremos fazer alguma coisa que dê informação para os bispos”. Então, me pediram para organizar, aqui em São Paulo, um curso de comunicação para os bispos. Eu já havia saído da Cásper Líbero e estava na USP. Eu disse: “Tudo bem”. E eles disseram: "Só que os jornalistas não podem tomar conhecimento disso". E eu respondi: "É muito difícil, porque se trata de um tema da atualidade e os jornais certamente vão pautar isso”. Então, eles engendraram o curso em um local a que ninguém tinha acesso. Então organizaram na Maternidade Santa Catarina, que era uma congregação que pertencia à irmã Benedicta Idelfet, que era uma freira finlandesa que vivia aqui há muitos anos. Então, nós demos o curso lá. Mas não tinha condições de manter o curso porque eles queriam, na verdade, uma espécie também de media training que chegasse também à televisão, mas nós teríamos que levá-los a uma emissora de televisão, porque naquele tempo, muitos bispos nem tinham visto uma emissora de televisão. Aí, fomos dar o curso lá na USP e não deu outra. Os jornalistas logo farejaram que aquilo ali era notícia, e saiu então nas manchetes do país inteiro que os bispos estavam estudando comunicação.

Mas, eu quero voltar à questão do jornalismo. Dos alunos que eu tive no curso, que eram dom Elder Câmara, dom Paulo Evaristo Arns, tinha inclusive dom Scherer, que era cardeal de Porto Alegre. Esse foi um aluno que me deu trabalho. Ele se interessou muito pelo 
jornalismo, pela parte ligada ao jornalismo. Ele queria saber os porquês de tudo. Quando eu trabalhei com a ideia de veracidade e outras características do jornalismo, ele sempre queria saber por que e perguntando mais. E eu fiquei, não digo, embasbacado, mas fiquei com dificuldade de responder porque, eu, na verdade, não os encarava como alunos, mas como bispos. E dom Scherer disse assim, uma ocasião: “Olha, professor, continue pesquisando esses temas e o senhor vai dar uma palestra para nós na Assembleia Nacional da CNBB, em Brasília para explicar como se faz jornalismo na Igreja”. Esse foi o maior desafio que eu tive, tremia feito vara verde porque cheguei lá em Brasília e tinha 300 bispos reunidos na assembleia. Então, eu tentei explicar para eles que era possível fazer jornalismo dentro da Igreja. Isso ajudou a mudar muito o comportamento da Igreja em relação ao jornalismo. Quer dizer que eles praticam um bom jornalismo.

P: O senhor acha que é possível fazer jornalismo, obedecer aos cânones do bom jornalismo, no contexto de uma instituição?

R: Sim. O que não pode é confundir jornalismo com propaganda, jornalismo com proselitismo, mas você pode evangelizar dando a boa informação.

P: Segundo as rádios ouvidas, evangelizar por meio do jornalismo para eles é valorizar os aspectos humanos da notícia, defender as causar sociais, a vida, a cidadania...

R: É um problema de agenda, uma questão de pauta. Porque, como você sabe, não existe jornalismo neutro. Todo jornalismo tem, na verdade, um parti pris, que é a posição editorial da empresa. Mas, quando o jornalismo é sério, a linha editorial, não significa que ela inibe a questão da veracidade, da objetividade da informação. Então, é possível fazer bom jornalismo dando só boas notícias, notícias positivas, evitando o sensacionalismo barato. Mas também não dá ser um jornalismo sempre "cor de rosa”. Eu dizia para os meus alunos que estudaram lá na USP, na Metodista, na Cásper Líbero, que o mundo não é tão cor de rosa assim. É preciso introduzir também algumas variáveis do cotidiano que deem às pessoas uma idéia da realidade tal qual ela é.

P: Mas, nesse caso, abordando de que forma?

R: Acho que a forma depende da audiência. Ou seja, se você tem uma rádio como a Aparecida, que é uma rádio de massa, que transmite para o Brasil inteiro, tem que levar em consideração o cidadão médio. Se você tem uma rádio de elite, então você pode trabalhar algumas formas mais sofisticadas de informação. Varia de veículo para veículo e de público para público.

P: Então, nós podemos dizer que existe, de fato, um jornalismo católico?

R: Sim, existe. Assim como existe um jornalismo protestante, um jornalismo comunista, e de qualquer matiz. 
P: Nesse caso, o senhor acredita que se trata de jornalismo institucional ou um gênero híbrido, como defendem alguns autores?

R: Depende. Vamos pegar o caso da Congregação das Paulinas. Elas fazem a revista Família Cristã, que é dirigida às famílias. Então, elas trabalham com temas ligados à infância, à adolescência, educação, ou seja, temas que interessam às famílias. Então, ela se limita a esses temas, mas não significa que não trate de outros problemas. Quando a irmã Joana Puntel fez a dissertação de Mestrado comigo, ela foi tratar exatamente do conteúdo da revista Família Cristã, das matérias que tinha ali. Então, você tinha de tudo. Só que o tratamento era dado no sentido de atender a pais e mães de família, tios e professores. Então, se você tem uma rádio como a Aparecida, que é mais geral, de massa, então, ela vai trabalhar com temas mais amplos, não vai ficar só ligada a temas que interessam à família. Você tem, talvez, uma rádio ligada a uma diocese que trabalha com os sem-terra. Ela vai dirigir o seu conteúdo para isso. Então, o jornalismo católico já é segmentado.

P: Alguns autores trabalham atualmente com o conceito de "hibridação” ou "hibridização" do jornalismo. No caso, o noticiário das rádios, ao incluir temas do cotidiano e também da Igreja Católica, poderia encaixar-se nesse conceito?

R: O problema é que a maioria das rádios católicas são católicas na propriedade, mas não são católicas na programação. Então, elas têm esse noticiário comum, como qualquer outra emissora, porque elas não estão buscando esse público propriamente católico, elas estão buscando audiência. Veja o caso das emissoras evangélicas. É difícil você ter uma emissora de rádio ou televisão evangélica que trate somente de temas ligados à religião. Veja o caso da Record. A Record é uma emissora pertencente à Igreja Universal do Reino de Deus, que tem uma programação como qualquer outra emissora de televisão. Onde entra o signo da religião? Nos programas ligados ao culto, na formação, vamos dizer, das consciências etc. Esse é o diferencial. Mas, o jornalismo da Record é um jornalismo igual a qualquer outro.

P: E com relação à inclusão de temas considerados tabus ou que sejam delicados para a Igreja com abordar?

R: Eu acho que os temas tabus têm que ser tratados porque, se você não tratar dos temas tabus na sua emissora, os outros vão tratar e podem tratar de maneira distorcida. O que não pode haver é sensacionalismo no sentido de exacerbação dos ânimos. Eu acho que as emissoras religiosas têm um papel, que é um papel, sobretudo, de acalmar a população. Mas, muitas emissoras de rádio pertencentes a organizações cristãs ou católicas, elas se preocupam pouco com isso. São comerciais, estão competindo com as demais e precisam ter uma programação como as demais. Você vê o caso da Record, ela tem uma programação como qualquer outra emissora, do Silvio Santos ou da Globo, mas com algumas novelas evangélicas, que retratam a Bíblia. 


\section{ANEXOS}

\section{ANEXO A}

Notícia publicada pelo site da Jornada Mundial da Juventude Rio 2013, no portal da Conferência Nacional dos Bispos do Brasil (CNBB) no dia 27/07/2013.

\section{Papa Francisco reitera importância do rádio na transmissão da fé católica}

Sábado, 27 de julho de 2013, 18h39.

Por: CNBB/Rádio Vaticano

No início da tarde deste sábado, 27 de julho, Papa Francisco visitou os estúdios da Rádio Catedral, mantida pela Arquidiocese do Rio de Janeiro. A emissora é a geradora da Rede Católica de Rádio (RCR) durante a Jornada Mundial da Juventude Rio 2013.

Durante sua rápida participação, Francisco deixou uma mensagem muito marcante sobre temas que delineiam as suas principais posições durante a Jornada Mundial da Juventude do Rio de Janeiro. Abaixo, a transcrição na íntegra das palavras do Papa.

“Bom dia, boa tarde, a todos que estão ouvindo. Agradeço a atenção e agradeço aqui aos integrantes da rádio pela amabilidade por me darem o microfone. Agradeço e estou olhando para o rádio e vejo que, hoje em dia, os meios de comunicação são muito importantes. Eu diria que, uma rádio católica, hoje em dia, é o púlpito mais próximo que temos de onde podemos anunciar os valores humanos, os valores religiosos e, sobretudo, anunciar a Jesus Cristo, ao Senhor. Dar ao Senhor essa graça de colocá-lo em nossas coisas.

Assim, saúdo a todos e agradeço todo o esforço que faz esta arquidiocese para ter e manter uma rádio, que tem uma rede tão grande. A todos que estão me escutando, peço que 
rezem por mim, que rezem por esta rádio, que rezem pelo bispo, que rezem pela arquidiocese, que todos possamos nos unir na oração e que todos trabalhemos por uma cultura mais humanista, mais repleta de valores e que não deixemos ninguém de fora.

Que todos trabalhemos por esta palavra que hoje em dia não é bem aceita: solidariedade. É uma palavra que procuram deixar de lado, sempre, porque é incômoda. Todavia, é uma palavra que reflete os valores humanos e cristãos que hoje nos pedem para ir contra; da cultura do descartável, de que tudo é descartável.

Uma cultura que sempre deixa as pessoas de fora: deixa à margem as crianças, deixa à margem os jovens, deixa à margem os idosos, deixa a fora aos que não servem, aos que não produzem, e isso não pode acontecer. A solidariedade coloca todos dentro. Devem seguir trabalhando por esta cultura da solidariedade e pelo Evangelho.”

Ao responder sobre a importância da família, o Papa Francisco reiterou o caráter indissolúvel desta.

“Não somente diria que a família é importante para a evangelização do novo mundo. A família é importante, é necessária para a sobrevivência da humanidade. Se não existe a família, a sobrevivência cultural da humanidade corre perigo. É a base, nos apeteça ou não: a família.”

Retirado do link: http://www.cnbb.com.br/site/comissoes-episcopais/comunicacao/12496papa-reitera-importancia-do-radio-na-transmissao-da-fe-catolica 
ANEXO B

CD - Gravações dos Radiojornais 